DOE/EIA-0603(96)

Distribution Category UC-950

\title{
Renewable Energy Annual 1996
}

\section{March 1997}

\author{
Energy Information Administration
}

Office of Coal, Nuclear, Electric and Alternate Fuels

U.S. Department of Energy

Washington, DC 20585
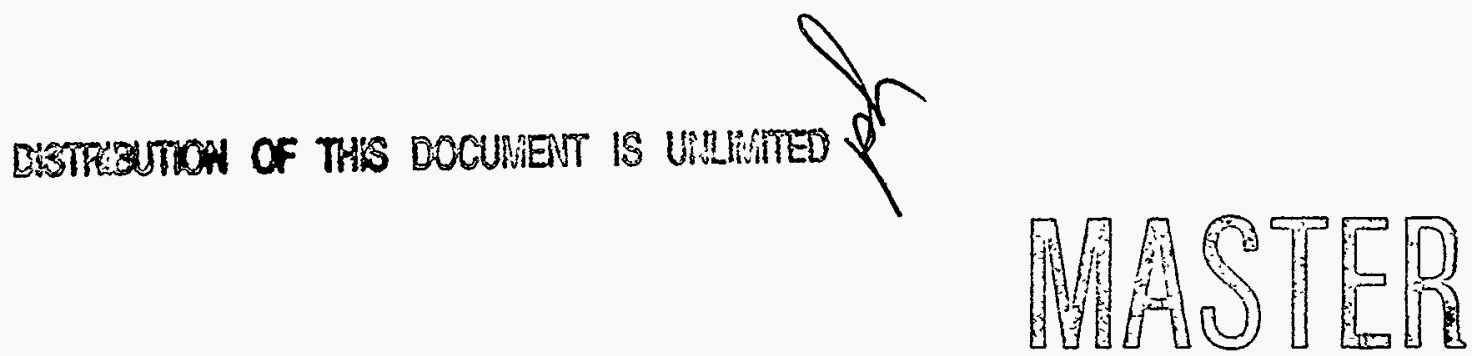

This report was prepared by the Energy Information Administration, the independent statistical and analytical agency within the Department of Energy. The information contained herein should not be construed as advocating or reflecting any policy position of the Department of Energy or of any other organization. 


\section{Contacts}

This report was prepared by the staff of the Renewable Energy Branch, Coal and Electric Data and Renewables Division, Office of Coal, Nuclear, Electric and Alternate Fuels. General information regarding this publication may be obtained from Fred Mayes, Chief, Renewable
Energy Branch (202/426-1166, e-mail fmayes@eia.doe. gov). Questions about the preparation and content of the report should be directed to Mark Gielecki, project coordinator (202/426-1141, e-mail mgieleck@eia.doe. gov).

Questions regarding specific chapters of the report should be directed as follows:

1. Renewable Data Overview .......... John Carlin Fred Mayes Louise Guey-Lee

2. Biomass Profile: Wood and Ethanol ...... Robert Lowe

3. Municipal Solid Waste Profile ........ John Carlin

4. Geothermal Energy Profile .......... Jim Disbrow

5. Wind Energy Profile ............. Mark Gielecki

6. Solar Industry Profile ............. Peter Holihan

7. The Role of Electric Utilities in the Photovoltaic Industry $\ldots \ldots \ldots \ldots$ Peter Holihan

8. Public Policy Affecting the Waste-to-Energy Industry . . . . . . . J John Carlin

9. Flow Control and the Interstate Movement of Waste: Post-Carbone ...... John Carlin

10. Growth of the Landfill Gas Industry ...... John Carlin

11. Management of Known Geothermal Resource Areas ................ Jim Disbrow

12. International Renewable Energy ....... Mark Gielecki
202/426-1146

202/426-1166

$202 / 426-1143$

$202 / 426-1171$

$202 / 426-1146$

$202 / 426-1185$

202/426-1141

202/426-1147

$202 / 426-1147$

202/426-1146

$202 / 426-1146$

202/426-1146

$202 / 426-1185$

202/426-1141 jcarlin@eia.doe.gov fmayes@eia.doe.gov lgueylee@eia.doe.gov rlowe@eia.doe.gov jcarlin@eia.doe.gov jdisbrow@eia.doe.gov mgieleck@eia.doe.gov jholihan@eia.doe.gov

jholihan@eia.doe.gov

jcarlin@eia.doe.gov

jcarlin@eia.doe.gov jcarlin@eia.doe.gov

jdisbrow@eia.doe.gov mgieleck@eia.doe.gov 


\section{DISCLAIMIER}

Portions of this document may be illegible in electronic image products. Images are produced from the best available original document. 


\section{DISCLAIMER}

This report was prepared as an account of work sponsored by an agency of the United States Government. Neither the United States Government nor any agency thereof, nor any of their employees, make any warranty, express or implied, or assumes any legal liability or responsibility for the accuracy, completeness, or usefulness of any information, apparatus, product, or process disclosed, or represents that its use would not infringe privately owned rights. Reference herein to any specific commercial product, process, or service by trade name, trademark, manufacturer, or otherwise does not necessarily constitute or imply its endorsement, recommendation, or favoring by the United States Government or any agency thereof. The views and opinions of authors expressed herein do not necessarily state or reflect those of the United States Government or any agency thereof. 


\section{Preface}

This report, the Renewable Energy Annual 1996, is the second in a series of annual reports published by the Energy Information Administration (EIA) to provide current information on renewable energy worldwide. In so doing, this report updates the information presented in the Renewable Energy Annual 1995 and further documents and explains renewable energy information provided in ELA's Annual Energy Review 1995. In addition, this report extends the scope of the previous issue by providing descriptive information on various segments of the renewable energy industry and discussions of new or ongoing renewable energy projects, as well as discussions of emerging economic and legal issues that affect the industry. It covers the following energy sources: biomass, geothermal, wind, and solar. While hydropower is a renewable energy resource, it is also regarded as a "conventional" energy source because it has furnished a significant amount of electricity for more than a century. Therefore, this report discusses hydropower as it contributes to total renewable energy consumption but does not address hydropower as an individual energy source. ${ }^{2}$ Also, EIA collects data only on terrestrial systems. Satellite and military applications are not included in this report. See Appendix A, "EIA Renewable Energy Data Sources," and Appendix B, "Renewable Data Limitations," for more detail.
The biomass sections of this report include updated information similar to that published in EIA's Estimates of U.S. Biomass Energy Consumption 1992 . $^{3}$ The solar sections include information similar to that previously published in Solar Collector Manufacturing Activity 1993. ${ }^{4}$ EIA has discontinued publishing the latter two reports.

The Energy Information Administration was established formally by the Department of Energy Organization Act of 1977 (Public Law 95-91). The legislation requires EIA to carry out a comprehensive, timely, and accurate program of energy data collection and analysis. It also vests EIA with considerable independence in determining its mission and the data and analyses it chooses to present. After approval by the EIA Administrator, products are not subject to further review. However, because EIA believes that collaborative efforts produce the best results, external reviews of its products-such as this report-are solicited, prior to approval, from other offices in the Department of Energy, other Federal agencies, and non-government experts. EIA remains the final judge of product content.

\footnotetext{
'Energy Information Administration, Renewable Energy Annual 1995, DOE/EIA-0603(95) (Washington, DC, December 1995), and Annual Energy Review 1995, DOE/EIA-0384(95) (Washington, DC, July 1996).

${ }^{2}$ For more information on hydropower, see, for example, Energy Information Administration, Electric Power Annual 1995, Vol. 1, DOE/EIA-0348(95/1) (Washington, DC, July 1996).

${ }^{3}$ Energy Information Administration, Estimates of U.S. Biomass Energy Consumption 1992, DOE/EIA-0548(92) (Washington, DC, May 1994).

'Energy Information Administration, Solar Collector Manufacturing Actioity 1993, DOE/EIA-0174(93) (Washington, DC, August 1994).
} 


\section{Acknowledgments}

The Energy Information Administration gratefully acknowledges the contributions of the following people:

From the National Renewable Energy Laboratory:

$$
\text { Jeff Fang }
$$

Solar

Robert McConnell

Tom Williams

\section{Geothermal \\ Vahab Hassani \\ Wind \\ Gerald Nix \\ Brian Parsons
Municipal Solid Waste
Carlton Wiles
Philip Shepherd \\ International
Sam Baldwin}

And:

Masood Akhtar

U.S. Department of Agriculture

Forest Products Laboratory

Jean Zellner

APA - The Engineered Wood Association

Tacoma, WA

Dan Brandon

Morbark Corporation

Winn, MI

Maria Zannes

Katie Cullen

Integrated Waste Services Association

Washington, DC 


\section{Contents}

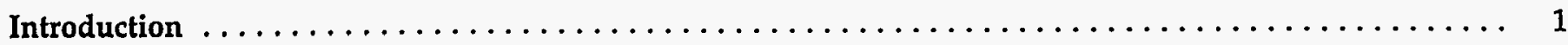

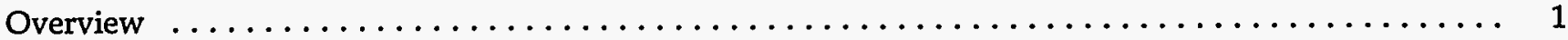

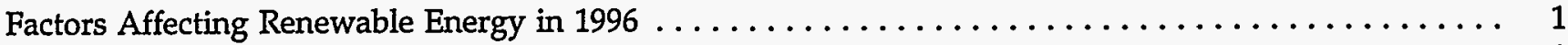

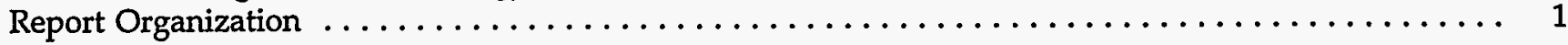

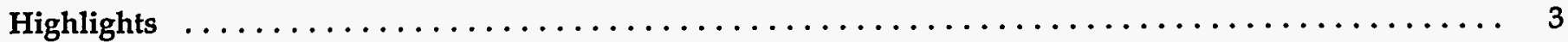

\section{Section I. Renewable Energy Data}

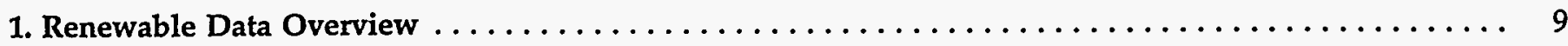

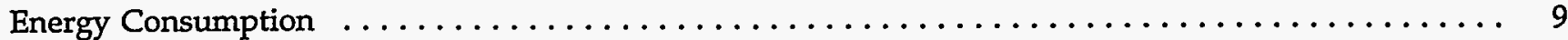

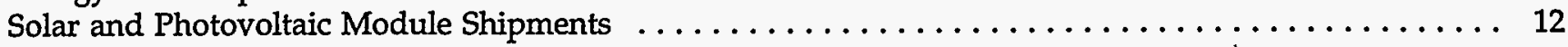

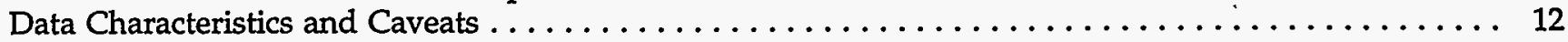

\section{Section II. Current Status and Industry Profiles}

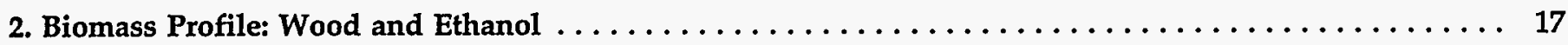

1996 Updates . . . . . . . . . . . . . . . . . . . . . . . . . . . . . . 17

Paper and Forest Product Industry Profiles $\ldots \ldots \ldots \ldots \ldots \ldots \ldots \ldots \ldots \ldots \ldots \ldots \ldots \ldots \ldots$

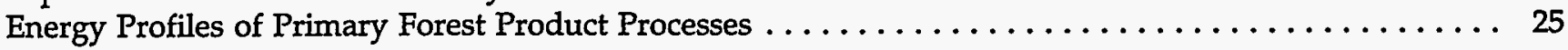

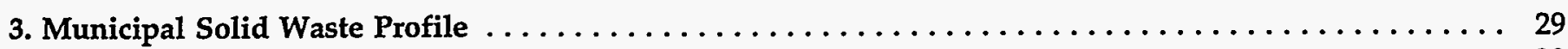

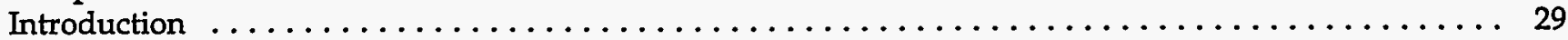

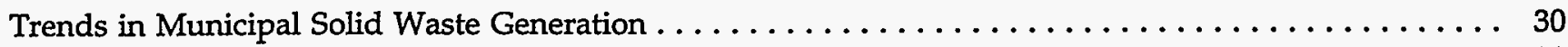

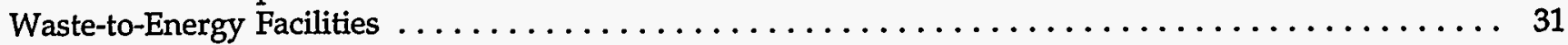

The Landfill Gas Industry $\ldots \ldots \ldots \ldots \ldots \ldots \ldots \ldots \ldots \ldots \ldots \ldots \ldots \ldots \ldots \ldots \ldots \ldots \ldots \ldots$

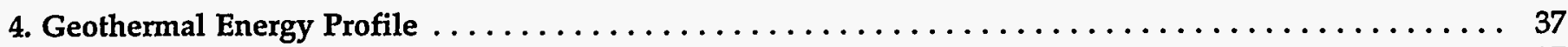

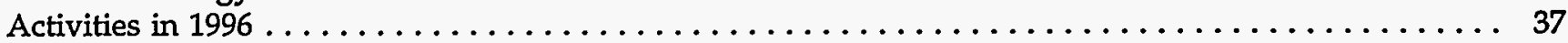

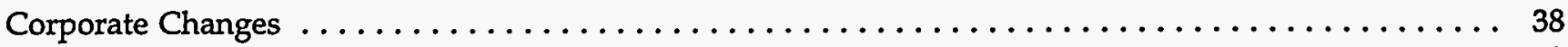

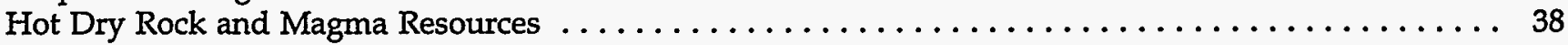

Direct Geothermal Energy $\ldots \ldots \ldots \ldots \ldots \ldots \ldots \ldots \ldots \ldots \ldots \ldots \ldots \ldots \ldots \ldots \ldots \ldots \ldots \ldots \ldots$

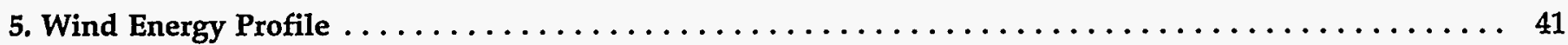

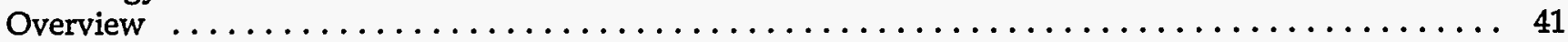

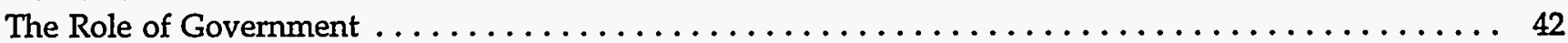

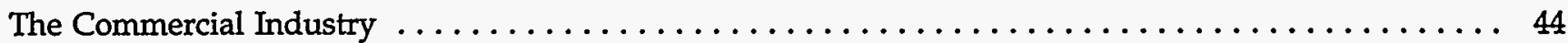

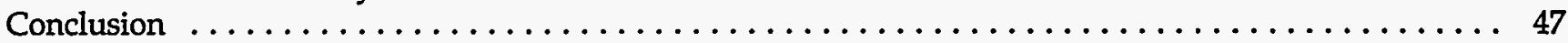

6. Solar Industry Profile $\ldots \ldots \ldots \ldots \ldots \ldots \ldots \ldots \ldots \ldots \ldots \ldots \ldots \ldots \ldots \ldots \ldots \ldots \ldots \ldots \ldots$

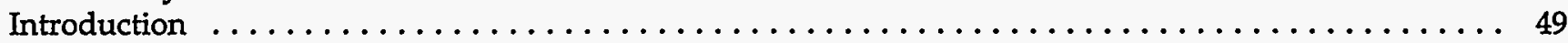

Solar Energy Data . . . . . . . . . . . . . . . . . . . . . . . . . . . . . . 50

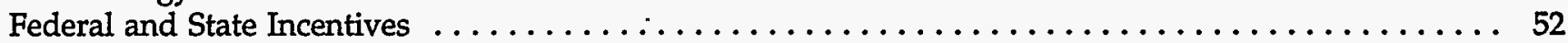

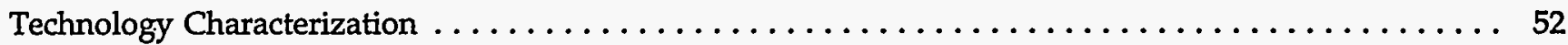

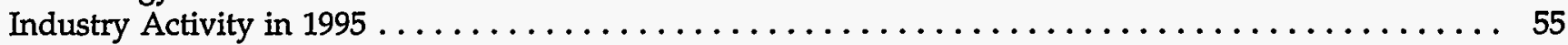

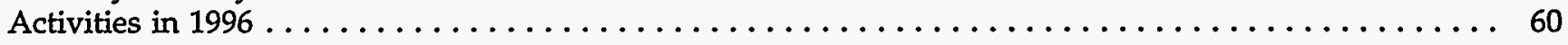




\section{Section III. Topical Issues}

7. The Role of Electric Utilities in the Photovoltaics Industry $\ldots \ldots \ldots \ldots \ldots \ldots \ldots \ldots \ldots \ldots \ldots$

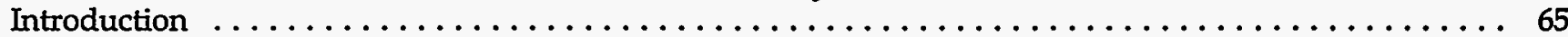

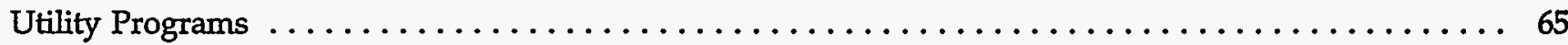

Utility-Scale PV Investment Under Industry Restructuring $\ldots \ldots \ldots \ldots \ldots \ldots \ldots \ldots \ldots \ldots \ldots \ldots \ldots 75$

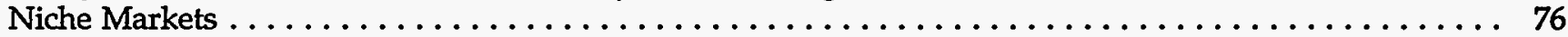

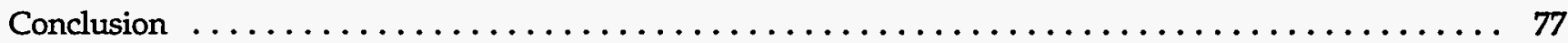

8. Public Policy Affecting the Waste-to-Energy Industry $\ldots \ldots \ldots \ldots \ldots \ldots \ldots \ldots \ldots \ldots \ldots \ldots \ldots \ldots . \ldots$

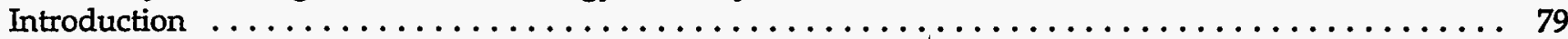

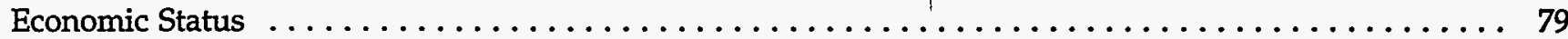

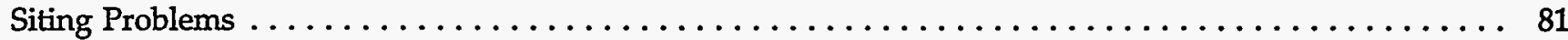

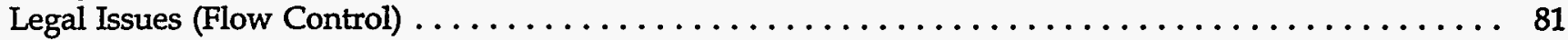

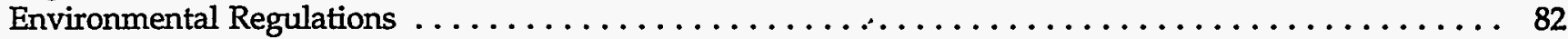

Utility and Energy Regulations $\ldots \ldots \ldots \ldots \ldots \ldots \ldots \ldots \ldots \ldots \ldots \ldots \ldots \ldots \ldots \ldots \ldots$

9. Flow Control and the Interstate Movement of Waste: Post-Carbone $\ldots \ldots \ldots \ldots \ldots \ldots \ldots \ldots \ldots \ldots$

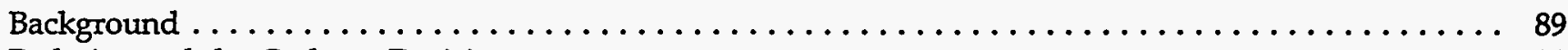

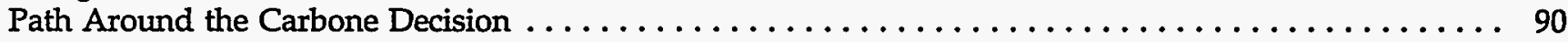

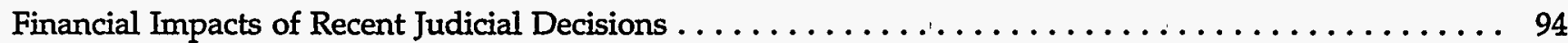

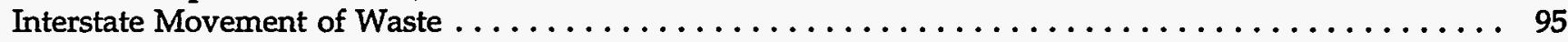

10. Growth of the Landfill Gas Industry $\ldots \ldots \ldots \ldots \ldots \ldots \ldots \ldots \ldots \ldots \ldots \ldots \ldots \ldots \ldots \ldots$

Municipal Solid Waste Landfills, Landfill Gas, and Control Systems . . . . . . . . . . . . . . 99

Development of the Landfill Gas Industry $\ldots \ldots \ldots \ldots \ldots \ldots \ldots \ldots \ldots \ldots \ldots \ldots \ldots \ldots \ldots \ldots$

LFG Utilization Applications $\ldots \ldots \ldots \ldots \ldots \ldots \ldots \ldots \ldots \ldots \ldots \ldots \ldots \ldots \ldots \ldots \ldots \ldots \ldots$

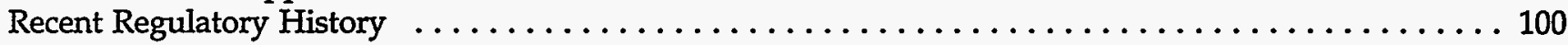

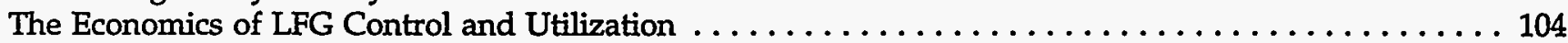

Nonregulatory Government Promotion of LFG Use $\ldots \ldots \ldots \ldots \ldots \ldots \ldots \ldots \ldots \ldots \ldots \ldots$

Economic Impacts of Regulations, Programs, and Incentives . . . . . . . . . . . . . . 110

11. Management of Known Geothermal Resource Areas $\ldots \ldots \ldots \ldots \ldots \ldots \ldots \ldots \ldots \ldots \ldots \ldots \ldots \ldots 113$

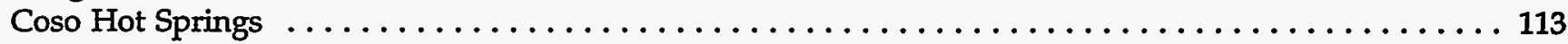

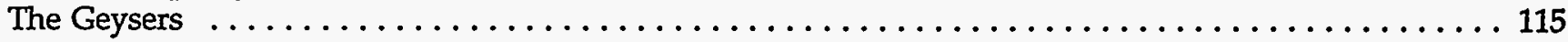

\section{Section IV. International Renewable Energy: Current Status and Prospects}

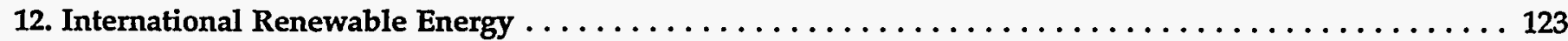

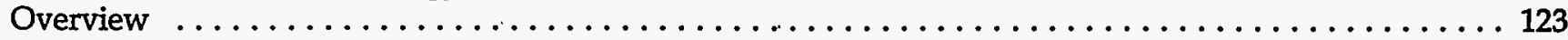

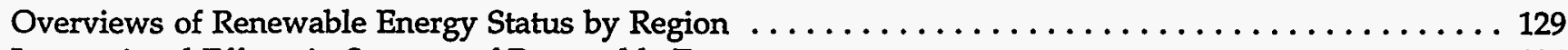

International Efforts in Support of Renewable Energy $\ldots \ldots \ldots \ldots \ldots \ldots \ldots \ldots \ldots \ldots \ldots \ldots \ldots \ldots$

U.S. Government Efforts in Support of Renewable Energy $\ldots \ldots \ldots \ldots \ldots \ldots \ldots \ldots \ldots \ldots \ldots \ldots$

Appendices

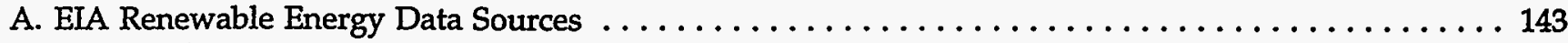

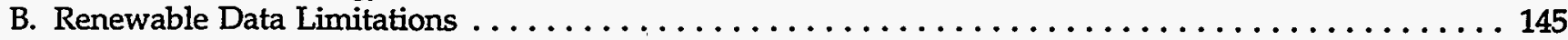

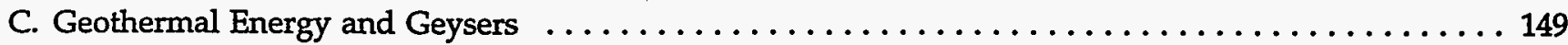

D. Environmental Impacts of Geothermal Energy $\ldots \ldots \ldots \ldots \ldots \ldots \ldots \ldots \ldots \ldots \ldots \ldots \ldots \ldots \ldots$

E. Examples of Contract Arrangements at The Geysers $\ldots \ldots \ldots \ldots \ldots \ldots \ldots \ldots \ldots \ldots \ldots \ldots$

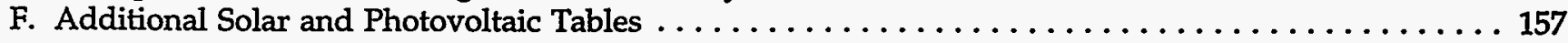

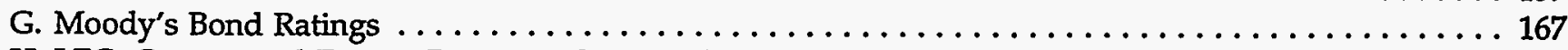

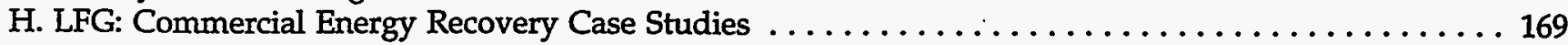

I. List of Internet Addresses: Renewable Energy Information by Resource $\ldots \ldots \ldots \ldots \ldots \ldots \ldots \ldots 171$

J. State Agencies That Provide Energy Information $\ldots \ldots \ldots \ldots \ldots \ldots \ldots \ldots \ldots \ldots \ldots \ldots \ldots$

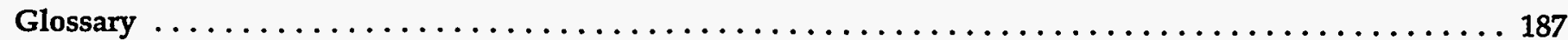


H1. U.S. Renewable Energy Consumption by Source, $1991-1995 \ldots \ldots \ldots \ldots \ldots \ldots \ldots \ldots \ldots \ldots \ldots \ldots$

1. U.S. Energy Consumption by Energy Source, $1991-1995$. . . . . . . . . . . . . . . . . . . . . 9

2. Renewable Energy Consumption by Sector and Energy Source, $1991-1995 \ldots \ldots \ldots \ldots \ldots \ldots \ldots \ldots$

3. Renewable Energy Consumption for Electricity Generation by Energy Source, 1991-1995 . . . . . . . . 11

4. Electricity Generation From Renewable Energy by Energy Source, $1991-1995$. . . . . . . . . . . . 12

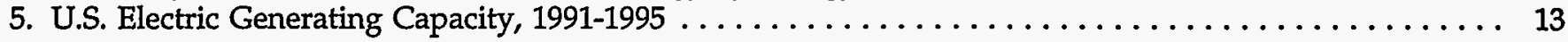

6. Regional Distribution of Pellet Fuel Shipments, $1992-1996 \ldots \ldots \ldots \ldots \ldots \ldots \ldots \ldots \ldots \ldots \ldots \ldots \ldots$

7. Energy and Raw Materials Inputs and Outputs of a Modern Sawmill . . . . . . . . . . . . 25

8. Historical and Projected U.S. Production of Municipal Solid Waste, Selected Years, 1960-2000 . . . . . 31

9. Waste-to-Energy Facilities by Type of Process and Region, $1996 \ldots \ldots \ldots \ldots \ldots \ldots \ldots \ldots \ldots \ldots \ldots$

10. Design Capacities of Waste-to-Energy Facilities by Process Type, $1996 \ldots \ldots \ldots \ldots \ldots \ldots \ldots \ldots \ldots$

11. Design Capacities of Waste-to-Energy Facilities by Region, $1996 \ldots \ldots \ldots \ldots \ldots \ldots \ldots \ldots \ldots \ldots$

12. Average Design Capacities of Waste-to-Energy Facilities by Type of Process and Region, 1996 . . . . . . 33

13. Air Pollution Control Equipment at Waste-to-Energy Facilities by Type of Process, 1996 . . . . . . . . . 34

14. Temperatures of Geothermal Fluids Required for Various Uses $\ldots \ldots \ldots \ldots \ldots \ldots \ldots \ldots \ldots \ldots$

15. U.S. Wind Electricity Generation Nameplate Capacity by State as of September $1996 \ldots \ldots \ldots \ldots$. . . 41

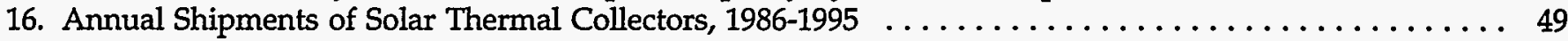

17. Annual Shipments of Photovoltaic Cells and Modules, $1985-1995 \ldots \ldots \ldots \ldots \ldots \ldots \ldots \ldots \ldots \ldots$

18. Annual Photovoltaic and Solar Thermal Shipments, $1974-1995 \ldots \ldots \ldots \ldots \ldots \ldots \ldots \ldots \ldots \ldots \ldots$

19. U.S. Utility Net Electric Generation from Solar Energy, $1995 \ldots \ldots \ldots \ldots \ldots \ldots \ldots \ldots \ldots \ldots \ldots \ldots \ldots$. . . 53

20. Estimated U.S. Solar and Total Energy Production, $1995 \ldots \ldots \ldots \ldots \ldots \ldots \ldots \ldots \ldots \ldots \ldots \ldots \ldots$

21. PVUSA Emerging Module Technology Systems at Davis, California . . . . . . . . . . . . . 66

22. PVUSA Utility Systems at Davis and Kerman, California $\ldots \ldots \ldots \ldots \ldots \ldots \ldots \ldots \ldots \ldots \ldots \ldots \ldots$

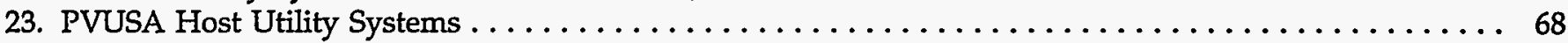

24. Utility Photovoltaic Group (UPVG) TEAM-UP Ventures, $1995 \ldots \ldots \ldots \ldots \ldots \ldots \ldots \ldots \ldots \ldots$. . . . . . . 69

25. Sacramento Municipal Utility District (SMUD) Photovoltaic System Cost Improvement, 1993-1995 . . . . 71

26. Kerman Photovoltaic Plant Nontraditional Benefits . . . . . . . . . . . . . . . . . . 74

27. Waste Generated, Exported, and Imported by Trading Partners, $1993 \ldots \ldots \ldots \ldots \ldots \ldots \ldots \ldots \ldots$

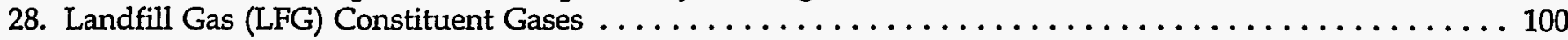

29. Regulatory Milestones Affecting the Landfill Gas Industry, $1976-1996 \ldots \ldots \ldots \ldots \ldots \ldots \ldots \ldots \ldots$. . . . . 101

30. Comparison of Costs for Typical LFG Energy Recovery Technologies . . . . . . . . . . . . . . . 106

31. Conditions Necessary for Cost-Competitiveness in LFG Utilization Projects . . . . . . . . . . . . . 107

32. Critical Barriers Identified by the Landfill Methane Outreach Program and Their Solutions . . . . . . . . 109

33. Comparison of MSW Landfill Costs Before and After the 1991 RCRA Regulations . . . . . . . . . . . 110

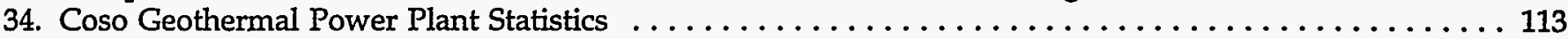

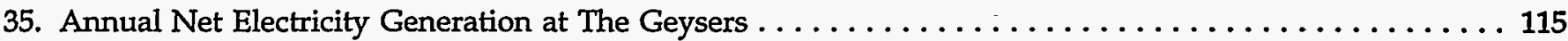

36. Installed Wind Capacity and Projected Capacity Additions for Selected Countries . . . . . . . . . 124

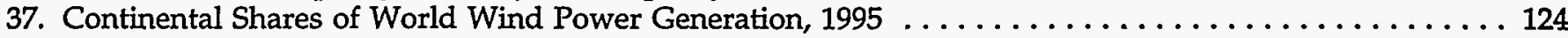

38. Destination of U.S. Photovoltaic Cell and Module Export Shipments by Country, 1995 . . . . . . . . . 125

39. Installed Geothermal Electricity Generation Capacity by Country, 1990, 1995, and 2000 . . . . . . . . 127

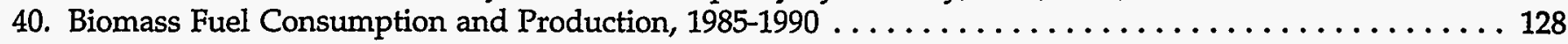

41. Advantages and Disadvantages of Charcoal as a Source of Energy . . . . . . . . . . . . . 128

42. Renewable Energy Resources and Market Potential in Asia and the Pacific and Africa . . . . . . . . 130

43. Renewable Energy Resources and Market Potential in the Americas . . . . . . . . . . . . . 131

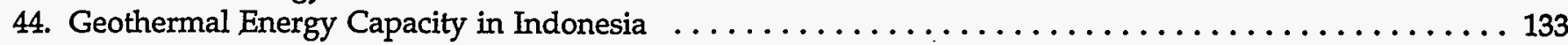

45. World Bank Renewable Energy Projects, Approved and in the Pipeline, 1996 . . . . . . . . . . . 135

46. USAID Renewable Energy Host Country Projects Under BEST and REAT as of December 31, $1995 \ldots \ldots 137$

B1. Evaluation of ELA's Undercoverage of Nonutility Electricity Data . . . . . . . . . . . . . 146

B2. Geothermal Energy Supplied for Major Direct Use Applications, 1993 . . . . . . . . . . . . . . . 147

F1. Number of Companies Expecting To Introduce New Solar Thermal Collector Products, 1996 . . . . . . . 157

F2. Percent of Solar Collector Shipments by the 10 Largest Companies, 1986-1995 . . . . . . . . . . . . . 157

F3. Companies Involved in Solar Thermal Activities by Type, 1994 and $1995 \ldots \ldots \ldots \ldots$. . . . . . . . . 157

F4. Solar-Related Sales as a Percentage of Total Sales, 1994 and $1995 \ldots \ldots \ldots \ldots \ldots \ldots \ldots \ldots \ldots \ldots$ 
F5. Annual Shipments of Solar Thermal Collectors by Type, $1986-1995 \ldots \ldots \ldots \ldots \ldots \ldots \ldots$. . . . . . 158

F6. Shipments of Solar Collectors Ranked by Top Five Origins and Destinations, 1994 and 1995 . . . . . 158

F7. Distribution of Solar Thermal Collector Shipments, 1994 and 1995 . . . . . . . . . . . . . . . . . . 159

F8. Solar Thermal Collector Shipments by Type, Quantity, Value, and Average Price, 1994 and 1995 . . . . 159

F9. Shipments of Solar Collectors by Market Sector, End Use, and Type, 1994 and 1995 . . . . . . . . . 160

F10. Shipments of Solar Thermal Collectors by Destination, $1995 \ldots \ldots \ldots \ldots \ldots \ldots \ldots \ldots \ldots \ldots \ldots \ldots$

F11. Distribution of U.S. Solar Thermal Collector Exports by Country, $1995 \ldots \ldots \ldots \ldots \ldots \ldots \ldots \ldots$

F12. Shipments of Complete Solar Thermal Collector Systems, 1994 and $1995 \ldots \ldots \ldots \ldots \ldots \ldots \ldots$

F13. Companies Expecting To Introduce New Photovoltaic Products in $1996 \ldots \ldots \ldots \ldots \ldots \ldots \ldots \ldots$

F14. Employment in the Photovoltaic Manufacturing Industry, $1990-1995 \ldots \ldots \ldots \ldots \ldots \ldots \ldots$

F15. Number of Companies Involved in Photovoltaic-Related Activities, 1994 and 1995 . . . . . . . . . . 163

F16. Photovoltaic Cell and Module Shipments by Type, $1993-1995 \ldots \ldots \ldots \ldots \ldots \ldots \ldots \ldots$. . . . . . . . . . 164

F17. Distribution of Photovoltaic Cells and Modules, $1993-1995 \ldots \ldots \ldots \ldots \ldots \ldots \ldots \ldots \ldots \ldots \ldots$

F18. Photovoltaic Cell and Module Shipments by Type, 1994 and 1995 . . . . . . . . . . . . . . . . . 165

F19. Shipments of Photovoltaic Cells and Modules by Market Sector, End Use, and Type, 1994 and 1995 . . 165

F20. Export Shipments of Photovoltaic Modules and Cells by Type, $1995 \ldots \ldots \ldots \ldots \ldots \ldots \ldots \ldots \ldots$

F21. Destination of Photovoltaic Cell and Module Exports by Continent, $1995 \ldots \ldots \ldots \ldots \ldots \ldots \ldots \ldots$

F22. Shipments of Complete Photovoltaic Module Systems, 1993-1995 . . . . . . . . . . . . . . . 166

\section{Figures}

1. Nonhydroelectric Renewable Energy Consumption Shares by Energy Source, 1991-1995 . . . . . . . . 11

2. U.S. Average Corn Prices Received by Farmers, $1993-1996 \ldots \ldots \ldots \ldots \ldots \ldots \ldots \ldots \ldots \ldots \ldots \ldots$

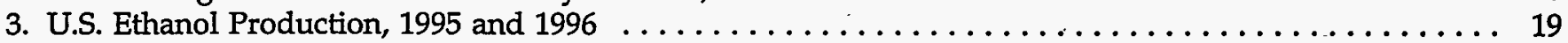

4. Net Sales of the Paper and Forest Products Industry, $1981-1995 \ldots \ldots \ldots \ldots \ldots \ldots \ldots \ldots \ldots \ldots$

5. Industrial Production Index of the Paper and Forest Products Industry, $1947-1995 \ldots \ldots \ldots \ldots \ldots \ldots$

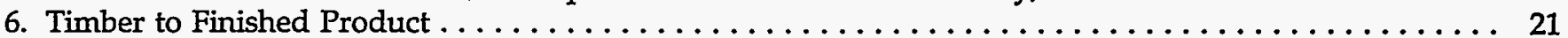

7. Chief Components of Municipal Solid Waste Management . . . . . . . . . . . . . . . . . . 29

8. Total U.S. Waste Generation Before Recycling, $1994 \ldots \ldots \ldots \ldots \ldots \ldots \ldots \ldots \ldots \ldots \ldots \ldots \ldots$

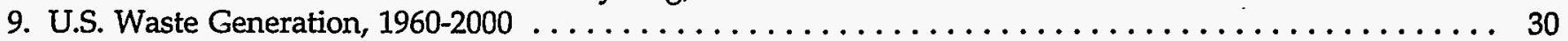

10. Number of Facilities Performing Waste-to-Energy Operations by Process Type, 1996 . . . . . . . . 32

11. Energy Production from Waste-to-Energy Facilities by Type of Energy, $1996 \ldots \ldots \ldots \ldots \ldots \ldots \ldots$

12. Waste-to-Energy Facilities by Type of Ownership, $1996 \ldots \ldots \ldots \ldots \ldots \ldots \ldots \ldots \ldots \ldots \ldots \ldots \ldots$

13. Waste-to-Energy Facilities by Relationship of Owner to Operator, $1996 \ldots \ldots \ldots \ldots \ldots \ldots \ldots \ldots \ldots$

14. Waste-to-Energy Facilities by Type of Operator, $1996 \ldots \ldots \ldots \ldots \ldots \ldots \ldots \ldots \ldots \ldots \ldots \ldots$

15. Location of Existing Landfill Facilities by Region, $1994 \ldots \ldots \ldots \ldots \ldots \ldots \ldots \ldots \ldots \ldots \ldots \ldots$

16. Number of Landfill Gas Processing Facilities Entering Service by Year, 1979-1994 . . . . . . . . . . . . 35

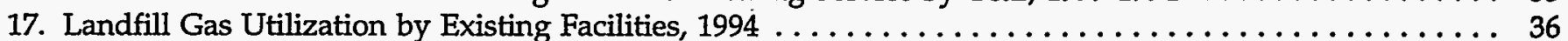

18. Solar Thermal Collector Shipments by Collector Type, $1983-1995 \ldots \ldots \ldots \ldots \ldots \ldots \ldots \ldots \ldots$

19. Import and Export Shipments of Photovoltaic Cells and Modules, $1987-1995$. . . . . . . . . . . 50

20. Import and Export Shipments of Solar Thermal Collectors, $1983-1995$. . . . . . . . . . . . . . . . . . 56

21. Average Price of Solar Thermal Collector Shipments by Collector Type, 1994 and 1995 . . . . . . . . 56

22. Domestic and Export Shipments of Photovoltaic Cells and Modules, 1987-1995 . . . . . . . . . . 58

23. Photovoltaic Cell and Module Shipments by Type, $1993-1995 \ldots \ldots \ldots \ldots \ldots \ldots \ldots \ldots \ldots \ldots \ldots$

24. Average Price of Photovoltaic Cell and Module Shipments by Type, 1993-1995 . . . . . . . . . . 59

25. Annual Net Generation from The Geysers, $1983-1995 \ldots \ldots \ldots \ldots \ldots \ldots \ldots \ldots \ldots \ldots \ldots \ldots \ldots$

26. Annual Steam Production and Injection at The Geysers, 1987-1994 . . . . . . . . . . . . . . . . . 117

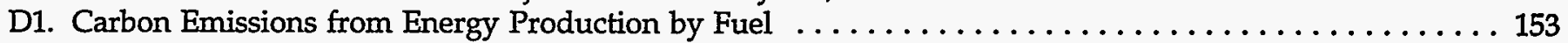




\section{Introduction}

\section{Overview}

This report presents summary data on renewable energy consumption, the status of each of the primary renewable technologies, a profile of each of the associated industries, an analysis of topical issues related to renewable energy, and information on renewable energy projects worldwide. It is the second in a series of annual reports on renewable energy (the inaugural issue, Renewable Energy Annual 1995, was published in December 1995). The renewable energy resources included in the report are biomass (wood and ethanol); municipal solid waste, including waste-to-energy and landfill gas; geothermal; wind; and solar energy, including solar thermal and photovoltaic. The report also includes various appendices and a glossary. ${ }^{5}$

\section{Factors Affecting Renewable Energy in 1996}

At the start of 1995, regulatory and economic pressures were already forcing the electric power industry to become more competitive. ${ }^{6}$ Since then, the deregulation of the industry has accelerated with the issuance of two Federal Energy Regulatory Commission (FERC) orders. ${ }^{7}$ In May 1996, the FERC issued Orders 888 and 889 , which require utilities to functionally unbundle transmission from generation and to open transmission systems to all wholesale transmission on a real-time, nondiscriminatory basis. Order 888 also permits full recovery of jurisdictional stranded costs through a nonbypassable charge on departing customers.

In addition, Congress is considering repealing or extensively modifying the Public Utility Regulatory Policies Act (PURPA) and the Public Utility Holding Company
Act (PUHCA). Repeal or extensive modification of PURPA would strengthen the relative position of large utilities and large, well-capitalized nonutility generators, and it would potentially weaken the position of the renewable energy industry. In particular, Section 210 of PURPA mandates the purchase of power from qualifying facilities (QFs) - small power facilities whose rated capacity does not exceed 80 megawatts and which are no more than 50 percent owned by a utility-at avoided-cost rates. Repeal of Section 210 could hamper the continued development of renewable energy. Repeal of PUHCA would remove regulatory barriers to utility mergers with nonutilities. Numerous State regulatory commissions have also begun various activities designed to promote retail competition.

Partly in response to these actions, two separate activities have been proposed to promote the continued commercialization of renewable energy technologies. Proposed legislation to deregulate the electric power industry includes provisions for "portfolio standards" specified minimum levels of renewable-generated electricity at the State level. ${ }^{8}$ In addition, electric utilities are using a voluntary approach, generically known as "green pricing" programs, to promote the use of renewable energy. ${ }^{9,10}$ Subscribers to green pricing programs voluntarily pay a premium for electricity generated from renewable sources. Numerous such programs are either in existence or proposed.

\section{Report Organization}

The first chapter of this report provides an overview of renewable energy data from 1991 through 1995. The five industry profiles that follow include information on the number, types, and sizes of companies that make up each industry; economic and financial characteristics

\footnotetext{
${ }^{5}$ The following people provided technical data collection, research on technical issues, substantive technical review, and publications and editorial contributions: Eileen B. Berenyi, Harry Chernoff, Gabriel Sanchez, Kevin Hill, William Turner, Brent Becker, Elizabeth Kinner, and Charles L. Smith.

${ }^{6}$ Energy Information Administration, Renewable Energy Annual 1995, DOE/EIA-0603(95) (Washington, DC, December 1995), p. xxix.

${ }^{7}$ For a full discussion of this issue, see Energy Information Administration, The Changing Structure of the Electric Power Industry: An Update, DOE/EIA-0562(96) (Washington, DC, December 1996).

${ }^{8}$ H.R. 3790, "The Electricity Consumers' Power To Choose Act of 1996" Ouly 17, 1996).

'H.R. 3790, "The Electricity Consumers' Power To Choose Act of 1996," p. xxx.

${ }^{10}$ Energy Information Administration, The Changing Structure of the Electric Power Industry: An Update.
} 
of the industry; and changes in the industry over time. The next section of the report includes five chapters on topical issues: "The Role of Electric Uitilities in the Photovoltaic Industry," "Public Policy Affecting the Waste-to-Energy Industry," "Growth of the Landfill Gas Industry," "Flow Control and the Interstate Movement of Waste: Post-Carbone," and "Management of Known Geothermal Resource Areas." The final chapter of the report discusses international developments in the renewable energy arena.

Appendix A describes EIA surveys that include information on renewable energy sources. Appendix B discusses renewable energy data and their limitations. Appendixes $C, D$, and $E$ provide ${ }^{-}$supplemental infor- mation and discussions related to geothermal energy. Appendix F presents detailed data on the U.S. solar thermal and photovoltaic energy industries collected by EIA in its annual surveys (Forms EIA-63A/B). Appendix $G$ reproduces the key to Moody's bond rating definitions, which are used in the discussion of flow control presented in Chapter 9. Appendix $\mathrm{H}$ shows selected case studies of landfill gas commercial energy recovery projects. Appendix I provides a list of internet addresses for web sites that include renewable energy information. Appendix J lists State agencies that provide energy information, including information on renewable energy. A glossary of renewable energy terms is also included. 


\section{Highlights}

The share of the Nation's total energy supply provided by renewable energy resources increased to 7.6 percent in 1995 (6.8 quadrillion Btu), up from 7.1 percent the previous year (Table H1). The increase was due primarily to a 17-percent jump in electricity generation from hydroelectric power. Nonhydroelectric renewable energy was essentially unchanged from 1994 levels. Renewable energy consumption has increased at a 2.2percent annual rate since 1991.

\section{Biomass: Wood and Ethanol}

Biomass energy consumption increased by 3.1 percent from 1994 to 1995, somewhat more than the 2.6-percent annual growth rate from 1991 to 1994 . Excluding hydropower, biomass accounted for 87 percent of the remaining renewable energy consumption in 1995.

Wood pellets, manufactured from finely ground wood fiber, represent a fast-growing biomass fuel market. In the residential and commercial sectors, an increase in residential wood use for heating resulted in a 10percent increase in renewable energy consumption in
1995. U.S. pellet fuel production increased by 18 percent between the 1993-94 and 1995-96 heating seasons.

Wildfires destroyed more than 5.4 million acres of brush and forest land during 1996, potentially affecting fiber supply. This was more than 2.5 times the 5-year average of nearly 2 million acres a year.

Fuel ethanol production dropped sharply in mid-1996 because of short corn supplies and high prices. Plant output began to increase toward the end of the growing season, reaching near-normal levels at the end of the year.

\section{Municipal Solid Waste}

Production of energy from municipal solid waste (MSW) supplies, which grew rapidly during the 1980s as a result of public policy at the Federal, State, and local levels that promoted the construction of waste-toenergy (WTE) facilities, has been curtailed during the 1990s. Current environmental policies encourage recycling and require costly pollution control at WTE

Table H1. U.S. Renewable Energy Consumption by Source, 1991-1995 (Quadrillion Btu)

\begin{tabular}{|c|c|c|c|c|c|}
\hline Energy Source & 1991 & 1992 & 1993 & 1994 & 1995 \\
\hline Conventional Hydroelectric Power ${ }^{\mathrm{a}}$. & R3.181 & R2.852 & R3.138 & R2.958 & 3.461 \\
\hline Geothermal Energy. & R0.347 & R0.367 & Ro.381 & R0.381 & 0.325 \\
\hline Biomass $^{b}$ & 2.642 & 2.788 & 2.784 & 2.852 & 2.941 \\
\hline Solar Energy ${ }^{c}$ & 0.068 & 0.068 & 0.069 & R0.068 & 0.073 \\
\hline Wind Energy. & 0.027 & 0.030 & 0.031 & 0.036 & 0.033 \\
\hline Total $\ldots \ldots \ldots \ldots \ldots \ldots \ldots \ldots \ldots \ldots$ & 6.265 & 6.106 & 6.403 & R6.296 & 6.832 \\
\hline
\end{tabular}

${ }^{\text {a}}$ Hydroelectricity generated by pumped storage is not included in renewable energy.

Includes wood, wood waste, peat, wood sludge, municipal solid waste, agricultural waste, straw, tires, landfill gases, fish oils, and/or other waste.

Includes solar thermal and photovoltaic.

$R=$ Revised data.

Notes: See "Data Characteristics and Caveats" section for a detailed explanation. Totals may not equal sum of components due to independent rounding.

Sources: 1991-1994: Energy Information Administration (EIA), Annual Energy Reviow 1995, DOE/EIA-0384(95) (Washington, DC, July 1996), Table 1.3. 1995: Consumption values based on the sum of electricity consumption from EIA, Electric Power Annual 1995, Vol. 2, DOE/EIA-0348(95/2) (Washington, DC, December 1996), and non-electricity consumption based on analysis by the Office of Coal, Nuclear, Electric and Alternate Fuels. 
facilities. Federal tax policy no longer favors investments in capital-intensive projects and limits municipal bond issues by States to finance the construction of facilities that are privately owned.

The WTE industry is also feeling the competitive pressures of deregulation. Electricity prices are dropping, and waste streams are going to the cheapest disposal option, which in many cases is out-of-State landfilling.

The MSW industry is also experiencing the effects of judicially driven deregulation decisions that have created uncertainty about the control of waste streams and protection of capital investments in WTE facilities. Two decisions by the U.S. Supreme Court (Fort Gratiot Landfill v. Michigan Department of Natural Resources and C\&A Carbone, Inc. v. Town of Clarkstown, New York) have outlawed waste management practices in many municipalities throughout the country; however, recent decisions by lower courts interpreting the Supreme Court guidance have provided legally acceptable paths for municipalities to follow in developing waste management systems.

The use of landfills as a waste disposal option is likely to increase in the near term; however, it is unlikely that many landfills will begin converting waste to energy because of unfavorable economics, particularly with electricity prices declining.

\section{Geothermal}

With the construction of new geothermal power facilities stalled, the most significant event in the U.S. geothermal industry in 1996 was the startup of a new 40-megawatt power plant in California, Salton Sea Unit IV.

Geothermal electricity generation continues to decline, falling to about 14.7 million kilowatthours in 1995 from its 1994 level of 17.1 million kilowatthours. Most notably, generation at The Geysers geothermal resource area has declined both for economic reasons and because of reduced steam pressure. Other facilities continue to produce steady quantities of electricity.

\section{Wind}

The domestic wind energy market has remained stable, even as market uncertainty increases with electric utility deregulation and restructuring. Wind-powered electricity generation totaled 3.2 million kilowatthours in 1995, down from 3.5 million kilowatthours in 1994.

California has, by far, more wind-powered generating capacity and electricity generation than any other State. In 1996, California had 95 percent of the operational wind capacity in the country. Minnesota, however, has 61 percent of the planned capacity.

Wind turbine performance continues to improve, and costs (both capital and operations and maintenance) continue to decline as wind energy projects are becoming increasingly geographically dispersed.

\section{Solar}

Solar energy consumption rose by 7 percent in 1995, mostly as a result of record nonutility solar-powered electricity generation.

The average price of solar thermal collectors dropped by 11 percent, from $\$ 3.73$ per square foot in 1994 to $\$ 3.29$ per square foot in 1995. Shipments of solar thermal collectors increased by 1 percent overall, with a 5-percent increase for medium-temperature collectors and a slight decrease (less than 0.5 percent) for lowtemperature collectors.

Shipments of photovoltaic modules and cells totaled 31.1 peak megawatts in 1995, an increase of 19 percent over 1994 shipments. The total value of photovoltaic module and cell shipments was $\$ 118$ million in 1994, 10 percent more than the value of shipments in 1985. The total value of crystalline silicon shipments in 1995 was $\$ 109.5$ million, 28 percent higher than the value of 1994 shipments.

Exports of photovoltaic modules and cells totaled 20 peak megawatts in 1994.

The use of photovoltaic modules and cells for gridinteractive electricity generation doubled, from 2.3 peak megawatts in 1994 to 4.6 peak megawatts in 1995, the second consecutive year of 100 -percent capacity growth.

\section{International Renewable Energy}

Additions to installed wind turbine capacity reached their single-year high in 1995-a total of 1,289 megawatts-bringing the worldwide cumulative total to 4,900 megawatts.

In the past 10 years, sales of photovoltaics worldwide have more than quadrupled, while installed costs have dropped by more than half. The rapid decline in the cost of photovoltaics and the development of niche markets have increased demand at a rate of 25 percent per year. In developing countries, demand has risen significantly. Manufacturers of photovoltaic cells and modules in the United States are currently exporting about two-thirds of their annual production (about 21 peak megawatts). 
Costa Rica has set a goal of producing 98 percent of its electricity from renewable sources by 2000 .

The Philippines is now the second-largest producer of geothermal electricity, after the United States, with a 1994 installed capacity of 1,191 megawatts. Total installed capacity is expected to reach 1,945 megawatts by 1998.
As of mid-1996, the World Bank and its Global Environmental Facility had a combined 41 renewable energy projects in several stages of development, from appraisal to ongoing.

Appendix I provides a list of internet addresses for web sites that include renewable energy information. 

Section I

Renewable Energy Data 



\section{Renewable Data Overview}

\section{Energy Consumption}

Renewable energy increased its market share of the Nation's energy supply in 1995, contributing 7.6 percent of total energy consumed (Table 1). In 1994, the share was 7.1 percent.

At 6.83 quadrillion British thermal units (Btu), 1995 renewable energy consumption was up by 8.5 percent from 1994 and stood at its highest level since the
Energy Information Administration began tracking total renewable energy consumption. The increase was fueled largely by a 17-percent jump in electricity generation from hydroelectric power. Nonhydroelectric renewable energy was essentially unchanged from 1994 levels. Renewable energy consumption has increased at a 2.2-percent annual rate since 1991. Sixty-five percent of total renewable energy consumption was used in generating electricity in 1995, up from 63 percent in 1994 (Tables 2 and 3).

Table 1. U.S. Energy Consumption by Energy Source, 1991-1995

(Quadrillion Btu)

\begin{tabular}{|c|c|c|c|c|c|}
\hline Energy Source & 1991 & 1992 & 1993 & 1994 & 1995 \\
\hline \multicolumn{6}{|l|}{ Fossil Fuels } \\
\hline Coal. & 18.770 & 18.868 & 19.430 & R19.544 & 19.618 \\
\hline Coking Coal (Net Imports) & 0.009 & 0.027 & 0.017 & 0.024 & 0.026 \\
\hline Natural Gas ${ }^{\mathrm{a}}$ & 19.606 & 20.131 & $\mathrm{R} 20.827$ & $\mathrm{R} 21.337$ & 22.202 \\
\hline Petroleum ${ }^{b}$. & 32.845 & 33.527 & 33.841 & R34.735 & 34.624 \\
\hline Total Fossil Fuels . . . . & 71.231 & 72.553 & $\mathbf{R 7 4 . 1 1 5}$ & R75.639 & 76.471 \\
\hline Nuclear Electric Power $\ldots \ldots \ldots \ldots \ldots \ldots$ & 6.579 & 6.607 & 6.519 & R6.837 & 7.189 \\
\hline Hydroelectric Pumped Storage ${ }^{c} \ldots \ldots \ldots \ldots$ & -0.047 & -0.043 & -0.041 & -0.035 & -0.027 \\
\hline \multicolumn{6}{|l|}{ Renewable Energy } \\
\hline Conventional Hydroelectric Power ${ }^{d}$ & R3.181 & $\mathrm{R} 2.852$ & R3.138 & R2.958 & 3.461 \\
\hline Geothermal Energy . . . . . . . . . . . . . & R0.347 & $\mathrm{R} 0.367$ & R0.381 & R0.381 & 0.325 \\
\hline Biomass $^{e} \ldots . . .$. & 2.642 & 2.788 & 2.784 & 2.852 & 2.941 \\
\hline Solar Energy ${ }^{f}$ & 0.068 & 0.068 & 0.069 & R0.068 & 0.073 \\
\hline Wind Energy $\ldots \ldots \ldots \ldots \ldots \ldots \ldots$ & 0.027 & 0.030 & 0.031 & 0.036 & 0.033 \\
\hline Total Renewable Energy ............ & 6.265 & 6.106 & 6.403 & R6.296 & 6.832 \\
\hline Total Energy Consumption ${ }^{g}$ & $\mathbf{R} 84.028$ & 85.223 & $\mathbf{R} 86.996$ & $\mathbf{R 8 8 . 7 3 8}$ & R90.465 \\
\hline
\end{tabular}

$a_{\text {Includes supplemental gaseous fuels. }}$

betroleum products supplied, including natural gas plant liquids and crude oil burned as fuel.

${ }^{c}$ Represents total pumped-storage facility production minus energy used for pumping.

dHydroelectricity generated by pumped storage is not included in renewable energy.

eIncludes wood, wood waste, peat, wood sludge, municipal solid waste, agricultural waste, straw, tires, landfill gases, fish oils, and/or other waste.

Includes solar thermal and photovoltaic.

' Excludes net imports of nonrenewable electricity; therefore, totals do not match those in Table 1.3 of the Annual Energy Review 1995.

$\mathrm{R}=$ Revised data.

Notes: See "Data Characteristics and Caveats" section for a detailed explanation. Totals may not equal sum of components due to independent rounding.

Sources: 1991-1995: Energy Information Administration (EIA), Annual Energy Review 1995, DOE/EIA-0384(95) (Washington, DC, July 1996), Table 1.3. 1995 Renewable Energy: Consumption values based on the sum of electricity consumption from EIA, Electric Power Annual 1995, Vol. 2, DOE/EIA-0348(95/2) (Washington, DC, December 1996), and non-electricity consumption based on analysis by the Office of Coal, Nuclear, Electric and Alternate Fuels. 
Biomass energy consumption increased by 3.1 percent from 1994 to 1995, somewhat more than the 2.6-percent annual growth rate from 1991 to 1994. Excluding hydropower, biomass accounted for 87 percent of the remaining renewable energy consumption in 1995 (Table 1 and Figure 1). Eighty percent of biomass consumption was used in non-electric applications in 1995, compared with 79 percent in 1994.

Wind energy consumption declined in 1995 to 0.033 quadrillion Btu-down from 0.036 quadrillion Btu in 1994. As a result, the position of wind energy as the fastest-growing source of renewable electricity generation was eroded. From 1990 to 1994, wind energy consumption had grown at a 10.7-percent annualized rate. Retirements of earlier-generation wind energy plants and relatively unfavorable wind conditions were responsible for the decline.
Geothermal energy consumption also dropped in 1995, to 0.325 quadrillion Btu from 0.381 quadrillion Btu in 1994. Production problems at The Geysers (a utilityowned facility in California) were responsible for most of the decline, and industrial generation also dropped.

After 4 years of virtually no growth, solar energy consumption rose by 7 percent in 1995, mostly as a result of record nonutility solar-powered generation. Virtually no solar electricity is generated in the electric utility sector.

The largest increase in renewable energy consumption in 1995 occurred in the electric utility sector as the result of increased hydroelectric generation (Table 3). In the residential and commercial sectors, an increase in residential wood use for heating resulted in a 10-percent increase in renewable energy consumption in 1995.

Table 2. Renewable Energy Consumption by Sector and Energy Source, 1991-1995 (Quadrillion Btu)

\begin{tabular}{|c|c|c|c|c|c|}
\hline Sector and Source & 1991 & 1992 & 1993 & 1994 & 1995 \\
\hline \multicolumn{6}{|l|}{ Residential/Commercial } \\
\hline Biomass $\ldots \ldots \ldots \ldots \ldots \ldots \ldots \ldots$ & 0.613 & 0.645 & 0.592 & 0.582 & 0.641 \\
\hline Solar ............ & 0.060 & 0.060 & 0.060 & 0.060 & 0.064 \\
\hline Total & 0.673 & 0.705 & 0.652 & 0.642 & 0.705 \\
\hline \multicolumn{6}{|l|}{ Industrial $^{\mathrm{a}}$} \\
\hline Biomass . & 1.943 & 2.042 & 2.084 & 2.152 & 2.178 \\
\hline Geothermal & 0.162 & 0.179 & 0.204 & 0.212 & 0.207 \\
\hline Conventional Hydroelectric $^{b}$. & 0.083 & 0.097 & 0.118 & 0.136 & 0.152 \\
\hline Solar . . . . . . . . . & 0.008 & 0.008 & 0.009 & 0.008 & 0.008 \\
\hline Wind & 0.027 & 0.030 & 0.031 & 0.036 & 0.033 \\
\hline Total $\ldots \ldots \ldots \ldots \ldots \ldots \ldots \ldots \ldots \ldots$ & 2.223 & 2.357 & 2.446 & 2.543 & 2.578 \\
\hline \multicolumn{6}{|l|}{ Transportation } \\
\hline Biomass $^{c}$ & 0.065 & 0.079 & 0.088 & 0.098 & 0.105 \\
\hline \multicolumn{6}{|l|}{ Electric Utility } \\
\hline Biomass .... . & 0.021 & 0.022 & 0.020 & 0.020 & 0.017 \\
\hline Geothermal & 0.170 & 0.169 & 0.158 & 0.145 & 0.099 \\
\hline Conventional Hydroelectric ${ }^{b}$. & 2.899 & 2.511 & 2.766 & 2.540 & 3.044 \\
\hline Șolar and Wind $\ldots \ldots \ldots \ldots$ & $\star$ & * & * & * & * \\
\hline Net Renewable Energy Imports ${ }^{d}$ & 0.214 & R0.263 & 0.271 & R0.309 & 0.283 \\
\hline Total $\ldots \ldots \ldots \ldots \ldots \ldots \ldots \ldots \ldots \ldots$ & 3.304 & 2.965 & 3.217 & R3.012 & 3.444 \\
\hline Total Renewable Energy Consumption & 6.265 & 6.106 & 6.403 & $\mathbf{R 6 . 2 9 6}$ & 6.832 \\
\hline
\end{tabular}

*Less than 0.5 trillion Btu.

ancludes generation of electricity by cogenerators, independent power producers, and small power producers.

${ }^{b}$ Hydroelectricity generated by pumped storage is not included in renewable energy.

Ethanol blended into gasoline.

Includes only net imports of electricity known to be from renewable resources (geothermal and hydroelectric).

$R=$ revised data.

Note: Totals may not equal sum of components due to independent rounding.

Sources: 1991-1994: Energy Information Administration (EIA), Annual Energy Review 1995, DOE/EIA-0384(95) (Washington, DC, July 1996), Table 10.1b. 1995: Electricity Consumption-EIA, Electric Power Annual 1995, Vol. 2, DOE/EIA-0348(95/2) (Washington, DC, December 1996). Non-electricity Consumption (except imports)-Based on analysis by the Office of Coal, Nuclear, Electric and Alternate Fuels. Net Renewable Energy Imports, 1991-1995: Based on analysis by the Office of Coal, Nuclear, Electric and Alternate Fuels. 
Figure 1. Nonhydroelectric Renewable Energy Consumption Shares by Energy Source, 1991-1995

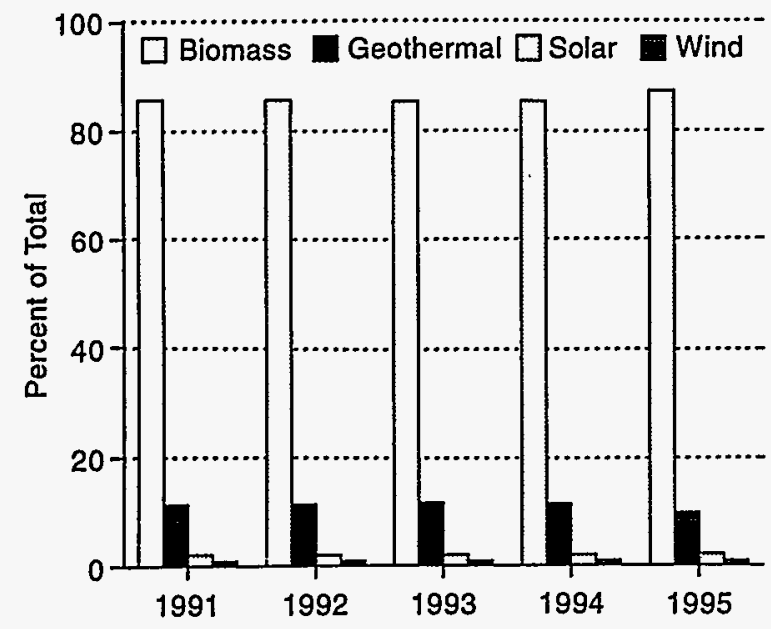

Source: Energy Information Administration, Annual Energy Review 1995, DOE/EIA-0384(95) (Washington, DC, July 1996), Table 1.3.
The distribution of renewable energy consumption by sector in 1995 was as follows: electric utility, 50 percent; industrial, 38 percent; residential and commercial, 10 percent; and transportation, 2 percent.

Renewable electricity generation ${ }^{11}$ rose to 415 billion kilowatthours (Table 4), an increase of 12 percent from 1994. Hydroelectricity was mainly responsible for the increase. Net imports of renewable electricity dropped from 29 billion kilowatthours in 1994 to 27 billion in 1995, largely because of a drop in imports of hydroelectricity from Canada.

Nonutility generation from biomass decreased marginally, from 57.4 billion kilowatthours in 1994 to 56.9 billion in 1995. Utility generation from biomass decreased by 17 percent, from 2.0 billion kilowatthours to 1.6 billion kilowatthours.

Both utility and nonutility generation of electricity from geothermal energy decreased in 1995, by a combined total of 2.4 billion kilowatthours. Utility generation

Table 3. Renewable Energy Consumption for Electricity Generation by Energy Source, 1991-1995 (Quadrillion Btu)

\begin{tabular}{|c|c|c|c|c|c|}
\hline Source & 1991 & 1992 & 1993 & 1994 & 1995 \\
\hline \multicolumn{6}{|l|}{ Industrial Sector ${ }^{\mathrm{a}}$} \\
\hline Biomass $\ldots \ldots \ldots \ldots \ldots \ldots \ldots \ldots$ & 0.506 & 0.552 & 0.573 & 0.590 & 0.585 \\
\hline Geothermal $\ldots \ldots \ldots \ldots \ldots \ldots \ldots$ & 0.162 & 0.179 & 0.204 & 0.212 & 0.207 \\
\hline Hydroelectric $\ldots \ldots \ldots \ldots \ldots \ldots \ldots$ & 0.083 & 0.097 & 0.118 & 0.136 & 0.152 \\
\hline Solar $\ldots \ldots \ldots \ldots \ldots \ldots \ldots \ldots \ldots$ & 0.008 & 0.008 & 0.009 & 0.008 & 0.008 \\
\hline$\ldots \ldots \ldots \ldots \ldots$ & 0.027 & 0.030 & 0.031 & 0.036 & 0.033 \\
\hline Total....... & 0.786 & 0.867 & 0.936 & 0.982 & 0.985 \\
\hline \multicolumn{6}{|l|}{ Electric Utility Sector ${ }^{b}$} \\
\hline Biomass $\ldots \ldots \ldots \ldots \ldots \ldots \ldots \ldots$ & 0.021 & 0.022 & 0.020 & 0.020 & 0.017 \\
\hline Geothermal $\ldots \ldots \ldots \ldots \ldots \ldots \ldots \ldots$ & 0.170 & 0.169 & 0.158 & 0.145 & 0.099 \\
\hline Conventional Hydroelectric ... & 2.899 & 2.511 & 2.766 & 2.540 & 3.044 \\
\hline Solar and Wind $\ldots \ldots \ldots \ldots \ldots$ & - & - & - & - & * \\
\hline Total $\ldots \ldots \ldots \ldots \ldots \ldots \ldots \ldots \ldots \ldots$ & 3.090 & 2.702 & 2.945 & 2.706 & 3.161 \\
\hline \multicolumn{6}{|l|}{ Imports and Exports } \\
\hline Geothermal (Imports) & 0.015 & 0.019 & 0.018 & R0.025 & 0.019 \\
\hline Conventional Hydroelectric (Imports) $\ldots \ldots \ldots$ & 0.231 & 0.278 & 0.294 & R0.313 & 0.296 \\
\hline Conventional Hydroelectric (Exports) & 0.032 & 0.034 & 0.040 & R0.029 & 0.031 \\
\hline Total Net Renewable Energy Imports. & 0.214 & 0.263 & 0.271 & R0.309 & 0.283 \\
\hline Total $\ldots \ldots \ldots \ldots \ldots \ldots \ldots \ldots \ldots \ldots$ & 4.090 & 3.831 & 4.152 & R3.996 & 4.429 \\
\hline
\end{tabular}

*Less than 0.5 trillion Btu.

Includes generation of electricity by cogenerators, independent power producers, and small power producers.

${ }^{b}$ Excludes imports.

$\mathbf{R}=$ Revised data.

Note: Totals may not equal sum of components due to independent rounding.

Sources: Energy Information Administration, Form EIA-759, “Monthly Power Plant Report," and Form ElA-867, “Annual Nonutility Power Producer Report." Natural Resources Canada, Electric Power in Canada 1993 (Ottawa, Canada, 1994). Federal Energy Regulatory Commission, Form FE-781R, "Annual Report of International Electricity Export/Import Data."

\footnotetext{
${ }^{11}$ Renewable electricity generation equals the sum of domestic renewable electricity generation and net imported renewable electricity.
} 
accounted for most of the drop, from 6.9 billion kilowatthours in 1994 to 4.7 billion in 1995 . Production problems at The Geysers were primarily responsible for the decline. The total U.S. capacity for renewable electricity generation increased slightly in 1995 to 93.9 gigawatts (Table 5).

\section{Solar and Photovoltaic Module Shipments}

U.S. shipments of photovoltaic cells and modules rose by nearly 20 percent in 1995, to 31,000 peak kilowatts (see Table 17 in Chapter 6). Over the past 10 years, the annualized rate of increase has been 17 percent. Although unit prices fell, the value of shipments rose from $\$ 106$ million in 1994 to \$118 million in 1995 (see Table F18 in Appendix F).
Solar thermal collector shipments inched up by 1 percent in 1995, to 7.7 million square feet (see Table 17 in Chapter 6). Prices continued to decline, reaching $\$ 3.29$ per square foot, compared with $\$ 3.73$ in 1994 (see Table F8 in Appendix F).

\section{Data Characteristics and Caveats}

The data included in this report are characterized by certain limitations. Appendix B details the limitations and provides information about the quality of data on renewable energy consumption. In addition, some of the current data are different from the data published in the Renewable Energy Annual 1995. Specifically: (1) electric utility consumption data differ as a result of changes in heat rate conversions; and (2) estimates of electricity trade were revised.

Table 4. Electricity Generation From Renewable Energy by Energy Source, 1991-1995

(Thousand Kilowatthours)

\begin{tabular}{|c|c|c|c|c|c|}
\hline Source & 1991 & 1992 & 1993 & 1994 & 1995 \\
\hline \multicolumn{6}{|l|}{ Industrial Sector (Gross Generation) $^{\mathrm{a}}$} \\
\hline Biomass & $48,897,000$ & $53,607,000$ & $55,746,000$ & $57,392,000$ & $56,975,275$ \\
\hline Geothermal & $7,657,000$ & $8,578,000$ & $9,749,000$ & $10,122,000$ & $9,911,659$ \\
\hline Hydroelectric & $8,007,000$ & $9,446,000$ & $11,511,000$ & $13,227,000$ & $14,773,801$ \\
\hline Solar & 779,000 & 746,000 & 897,000 & 824,000 & 824,193 \\
\hline Wind & $2,650,000$ & $2,916,000$ & $3,052,000$ & $3,482,000$ & $3,185,006$ \\
\hline Total & $68,028,000$ & $75,293,000$ & $80,955,000$ & $85,047,000$ & $85,669,934$ \\
\hline \multicolumn{6}{|l|}{ Electric Utility Sector (Net Generation) ${ }^{b}$} \\
\hline Bion & 2,0 & 2,0 & 1,9 & & 178 \\
\hline Gec & 8,0 & 8,1 & 7,57 & 6,94 & $4,744,804$ \\
\hline droelect & $280,060,624$ & $243,736,029$ & $269,098,329$ & $247,070,938$ & $296,378,692$ \\
\hline Solar & 3,338 & 3,169 & 3,802 & 3,472 & 3,909 \\
\hline Wind & 285 & 308 & 243 & 309 & 11,097 \\
\hline Total & $290,197,801$ & $253,936,260$ & $278,663,780$ & $256,003,613$ & $302,776,523$ \\
\hline \multicolumn{6}{|l|}{ Imports and Exports } \\
\hline Geothermal (Imports) & 736,980 & 889,864 & 058 & 17 & 884,950 \\
\hline Conv & $22,318,503$ & $26,948,408$ & 28,558 & $\mathrm{R} 30,4$ & $28,823,244$ \\
\hline electric (Exports) & $3,138,562$ & $3,254,289$ & $3,938,973$ & $\mathrm{R} 2,806,712$ & $3,059,261$ \\
\hline Total Net Imports & $19,916,921$ & $24,583,983$ & $25,496,219$ & $\mathrm{R} 28,844,268$ & $26,648,933$ \\
\hline Total Renewable Electricity Generatic & $378,142,722$ & $353,813,243$ & $385,114,99$ & $69,894,881$ & $415,095,390$ \\
\hline
\end{tabular}

ancludes generation of electricity by cogenerators, independent power producers, and small power producers.

${ }^{b}$ Excludes imports.

$R=$ Revised data.

Notes: For the industrial sector, 1991-1994 gross generation was rounded; for 1995, more detail was available. Totals may not equal sum of components due to independent rounding.

Sources: Energy Information Administration, Form ElA-759, "Monthly Power Plant Report"; Form ElA-867, "Annual Nonutility Power Producer Report"; and Electric Power Annual 1995, Vol. 2, DOE/EIA-0348(95/2) (Washington, DC, December 1996). Natural Resources Canada, Electric Power in Canada 1994 (Ottawa, Canada, 1995). U.S. Department of Energy, Office of Fossil Energy, Form FE-781R, "Annual Report of International Electricity Export/Import Data." 
Table 5. U.S. Electric Generating Capacity, 1991-1995 (Megawatts) $^{\mathrm{a}}$

\begin{tabular}{|c|c|c|c|c|c|}
\hline Source & 1991 & 1992 & 1993 & 1994 & 1995 \\
\hline Hydroelectric $^{b}$ & 75,616 & 74,580 & 77,181 & 78,041 & 78,563 \\
\hline Geothermal & 2,600 & 2,910 & 2,978 & 3,006 & 2,968 \\
\hline Biomass $\ldots \ldots \ldots \ldots \ldots \ldots$ & 9,362 & 9,701 & 10,045 & 10,465 & 10,292 \\
\hline Solar/Photovoltaic & 323 & 339 & 340 & 333 & 333 \\
\hline Wind & 1,653 & 1,823 & 1,813 & 1,745 & $c_{1,731}$ \\
\hline Total Renewables & 89,554 & 89,353 & 92,357 & 93,590 & 93,887 \\
\hline Nonrenewables $^{d}$ & 648,364 & 656,563 & 661,222 & 668,819 & 675,643 \\
\hline Total $\ldots \ldots \ldots \ldots \ldots \ldots \ldots$ & 737,918 & 745,916 & 753,579 & 762,409 & 769,530 \\
\hline
\end{tabular}

${ }^{a}$ Capacity ratings for nonrenewables have been revised to reflect estimated net summer capability rather than nameplate capacity. The methodology for estimating net summer capability from reported nameplate capacity is presented in Energy Information Administration, Inventory of Power Plants in the United States as of January 1, 1996, DOE/EIA-0095(96), p. 262.

'Excludes pumped storage, which is included in "Nonrenewables."

${ }^{c}$ Excludes 6.6 megawatts of utility capacity and 35 megawatts of nonutility capacity that were not captured by EIA sources.

'Includes hydrogen, sulfur, batteries, chemicals, spent sulfite liquor, and hydroelectric pumped storage. For 1991, EIA utility hydroelectric pumped storage values were subtracted from renewable "hydroelectric" category estimates from the source used for renewable data. This pumped storage estimate was then added to the "nonrenewables" category. This was done to improve definitional consistency of the data shown, since EIA does not classify pumped storage as renewable energy.

Sources: Energy Information Administration, Form EIA-860, "Annual Electric Generator Report," and Form EIA-867, "Annual Nonutility Power Producer Report." 

Section II

Current Status and Industry Profiles 



\section{Biomass Profile: Wood and Ethanol}

\section{Updates}

This edition of the Renewable Energy Annual updates data on energy production from wood pellets and fuel ethanol. In addition, it features a profile of the U.S. forest products industry and reports on some of the industry's energy characteristics. Some of the data on the use of wood for energy production that were reported in the Renewable Energy Annual 1995 are not updated in this report. Those data are based on 3- and 5 -year surveys, whose cycles will not be completed until 1997. The surveys include the Energy Information Administration's “Manufacturing Energy Consumption Survey" and "Residential Energy Consumption Survey," as well as several statistical tables from the U.S. Forest Service data publication, Forest Resources of the United States.

\section{Wood Pellets}

Table 6 provides 1994-1995 and 1995-1996 updates for the data on wood pellet fuel reported in Table 25 of the Renewable Energy Annual 1995. Wood pellets, manufactured from finely ground wood fiber, represent a fastgrowing biomass fuel market. Wood pellets are typically $1 / 4$ to $5 / 16$ inch in diameter and about $3 / 4$ inch in length, weighing more than 40 pounds per cubic foot.
They are generally sold in 40-pound bags through stove suppliers, feed and seed stores, and home centers for use in pellet stoves.

U.S. production of pellet fuel has increased significantly from the 1993-1994 levels reported in the Renewable Energy Annual 1995. According to the Pellet Fuels Institute, ${ }^{12}$ there are currently 63 pellet manufacturers in North America, and U.S. shipments have increased by 18 percent since the 1993-1994 heating season, despite an 11-percent decline in 1995-1996 from the previous heating season due to warmer weather in Washington, Oregon, and California (Pacific region). The West (Pacific and Mountain regions) continues to dominate pellet fuel sales, consuming 66 percent of U.S. shipments in the 1995-1996 heating season.

Sales of pellet stoves continue to be good, and the industry is expected to grow in the near term, based on the following factors:

- Expansion as a result of targeting of regional markets by industry

- The extremely good combustion efficiency and emissions characteristics demonstrated by pellet stoves and their ease of use (resulting from their ability to control burn rate and automatically feed fuel)

Table 6. Regional Distribution of Pellet Fuel Shipments, 1992-1996 (Tons)

\begin{tabular}{|c|c|c|c|c|c|}
\hline Region & 1992-1993 & 1993-1994 & 1994-1995 & 1995-1996 & $\begin{array}{c}\text { Change from } \\
\text { 1993-1994 } \\
\text { (Percent) }\end{array}$ \\
\hline Northeast $\ldots \ldots \ldots \ldots \ldots$ & 35,000 & 62,000 & 84,000 & 107,000 & 73 \\
\hline Southeast...$\ldots \ldots \ldots \ldots$ & 16,000 & 21,000 & 34,000 & 39,000 & 86 \\
\hline Great Lakes & 11,000 & 26,000 & 24,000 & 36,000 & 38 \\
\hline Central ............... & 21,000 & 18,000 & 15,000 & 19,000 & 6 \\
\hline Mountain $\ldots \ldots \ldots \ldots \ldots$ & 145,000 & 130,000 & 120,000 & 123,000 & -5 \\
\hline$\ldots \ldots \ldots \ldots$ & 198,000 & 239,000 & 293,000 & 262,000 & 10 \\
\hline U.S. Total $\ldots \ldots \ldots \ldots \ldots$ & 426,000 & 496,000 & 570,000 & 586,000 & 18 \\
\hline Energy Yield (trillion Btu) ${ }^{a}$ & 7.2 & 8.4 & 9.7 & 10.0 & - \\
\hline
\end{tabular}

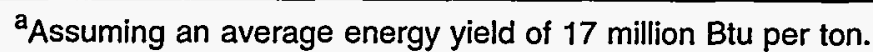

Note: The annual season runs from April 1 through March 31.

Source: Personal communication with and facsimile from Leslie Wheeler, Pellet Fuels Institute, Arlington, VA, December 19, 1996.

The author of this chapter is Robert Lowe, Renewable Industry Specialist, Energy Information Administration.

${ }^{12}$ Personal communication with Leslie Wheeler, Pellet Fuels Institute (Arlington, VA, 1996). 
- The advent of retailing of pellet stoves and fuel by some national chain "megastore" home centers, which display floor samples and offer programs such as free delivery of skid-quantity fuel purchases.

Total heat energy produced by pellet stoves in 19951996 was approximately 10 trillion Btu, equivalent to 1.7 million barrels of crude oil.

\section{Fuel Ethanol}

Corn is the primary feedstock used by the majority of U.S. fuel ethanol producers. Late planting in 1996 due to wet conditions resulted in late corn crop development and higher market prices (Figure 2). Ethanol production dropped sharply in mid-1996 (Figure 3). Net plant output was reduced because of short corn supplies and higher prices, and at some plants with the capability to do so, capacity was reallocated to other products. Production output began to increase toward the end of the growing season and reached a level comparable to December 1995 by year's end. In the corn market, over 95 percent of the crop had been harvested by early December, stocks had been replenished, and prices declined from their earlier highs. ${ }^{13}$
In contrast to the spring, weather conditions were reported to be nearly ideal in the Corn Belt in the latter part of the 1996 growing season. The U.S. Department of Agriculture expects corn prices to average in the range of $\$ 2.50$ to $\$ 2.80$ per bushel during the 1996-97 season, compared with an average of $\$ 3.24$ per bushel during the 1995-96 season. ${ }^{14}$

For the year, net fuel ethanol production in $1996^{15}$ was dramatically lower than in 1995, amounting only to about three-fourths of the 1995 industry output of about 1.34 billion gallons (101.6 trillion Btu at Lower Heating Value). ${ }^{16}$ However, 1996 ethanol production will still be close to 1 billion gallons, with an approximate energy equivalence of about 75 trillion Btu. According to the Department of Agriculture, ${ }^{17}$ the 1996-97 corn growing season is expected to be the third largest on record. This prospect is favorable for the fuel ethanol industry.

A separate but pivotal issue for the ethanol industry is the proposed reexamination of the Federal Motor Fuels Excise Tax exemption for gasohol by the 105th Congress. Favorable policy factors, such as contribution to employment and coproduct exports, are frequently cited by proponents of ethanol; however, claims have

Figure 2. U.S. Average Corn Prices Received by Farmers, 1993-1996

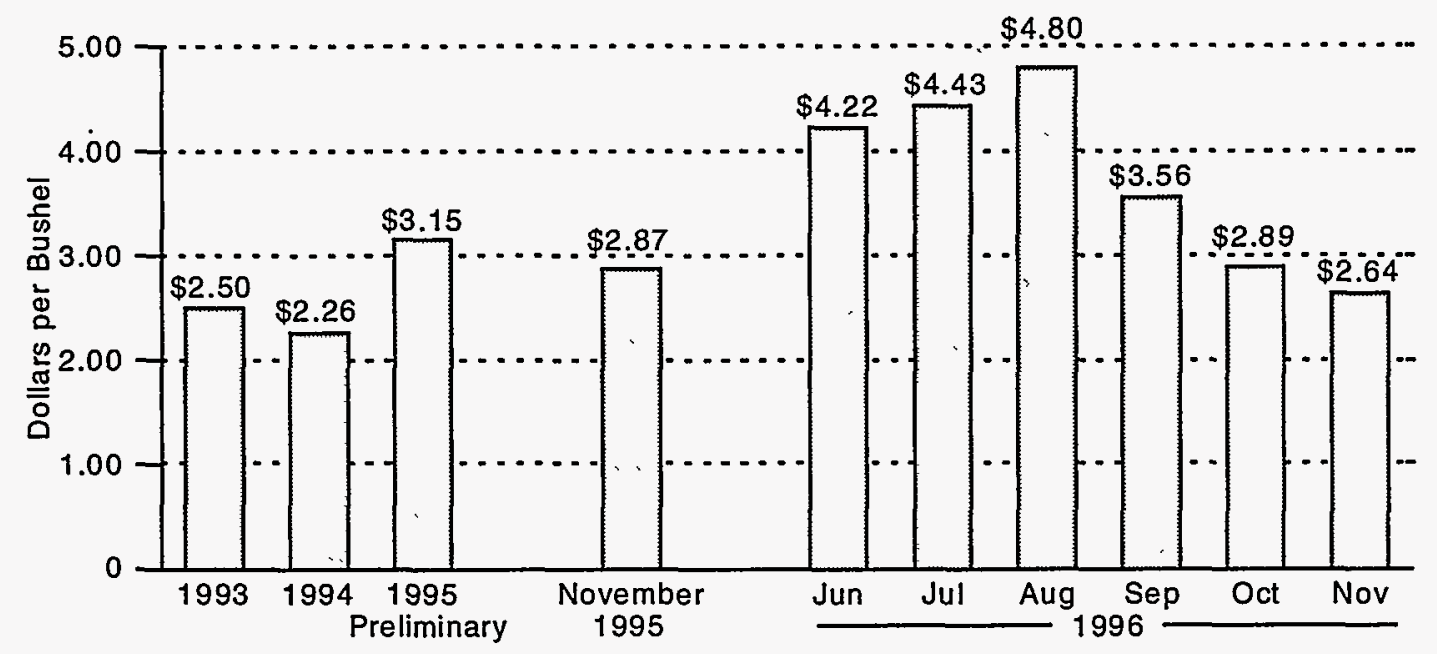

Source: U.S. Department of Agriculture, Economic Research Service, Agricultural Outlook, January-February 1997, AO-237 (Washington, DC, January 1997), Table 5, p. 41.

${ }^{13}$ U.S. Department of Agriculture, Economic Research Service, Agricultural Outlook, January-February 1997, AO-237 (Washington, DC, January 1997), p. 2.

${ }^{14}$ U.S. Department of Agriculture, Economic Research Service, Agricultural Outlook, January-February 1997, p. 2.

${ }^{15}$ Fourth quarter 1996 average monthly production levels were projected by the Office of Coal, Nuclear, Electric and Alternate Fuels to estimate an annual production total. Consideration was given to fourth-quarter estimates reported in Renewable Fuels Association, Ethanol Report, No. 39 (January 3, 1997).

${ }^{16}$ Energy Information Administration, Form EI-819M, "Monthly Oxygenate Telephone Report" (December 1995).

${ }^{17}$ U.S. Department of Agriculture, Economic Research Service, Agricultural Outlook, January-February 1997, p. 2. 
Figure 3. U.S. Ethanol Production, 1995 and 1996

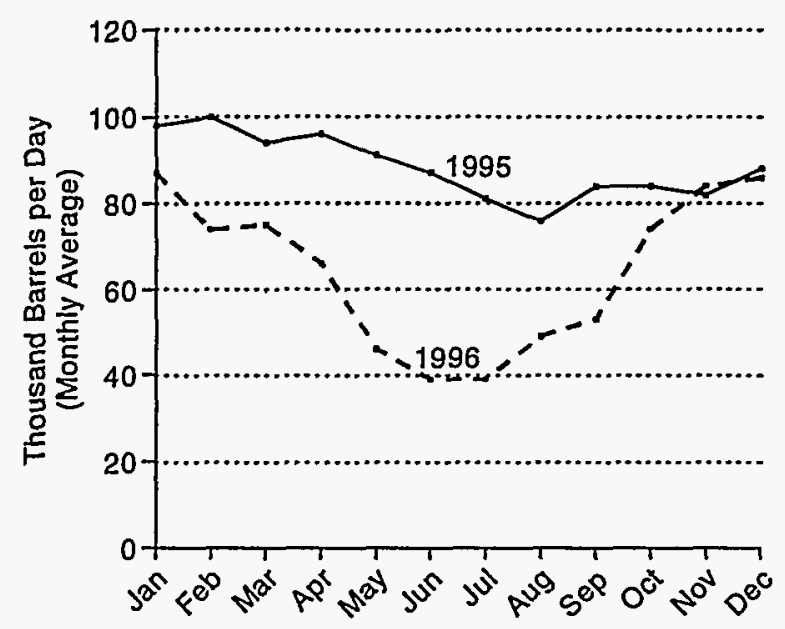

Source: Energy Information Administration, Form El-819M, "Monthly Oxygenate Telephone Report."

been made both for and against a positive net energy balance in ethanol production. A recent study by the Department of Agriculture estimated the energy balance associated with ethanol, including all aspects of crop and fuel production. The study found a weighted average net energy ratio (on a Btu per gallon basis) for corn-based ethanol of 1.24, indicating that ethanol replaces petroleum imports at a ratio of 7 to $1 .^{18}$

\section{Paper and Forest Product Industry Profiles}

The forest products industry is a large and important sector of American manufacturing. The pulp and paper subgroup of the forest products industry accounts for about two-thirds of the sector's manufacturing output. The pulp and paper industry (SIC designation "Paper and Allied Products"), considered by itself, is the tenthlargest manufacturing group in American industry. ${ }^{19}$ The forest products industry is populated by numerous electric power generators that use and sell steam and electricity. It is the largest self-generator of energy in American manufacturing, despite being only the thirdlargest consumer of electrical energy.
The present report compiled a 15-year profile of the 25 largest paper and forest manufacturing companies, based on investment information sources and the annual reports of individual companies. ${ }^{20}$ Total net sales of this industry segment grew from around $\$ 40$ billion in 1981 to about $\$ 105$ billion in 1995 (Figure 4). Figure 5 illustrates the economic performance of the forest products industry (i.e., buildings, furniture, etc.) beginning in 1947 and indexed to 1987 sales.

\section{Figure 4. Net Sales of the Paper and Forest Products Industry, 1981-1995}

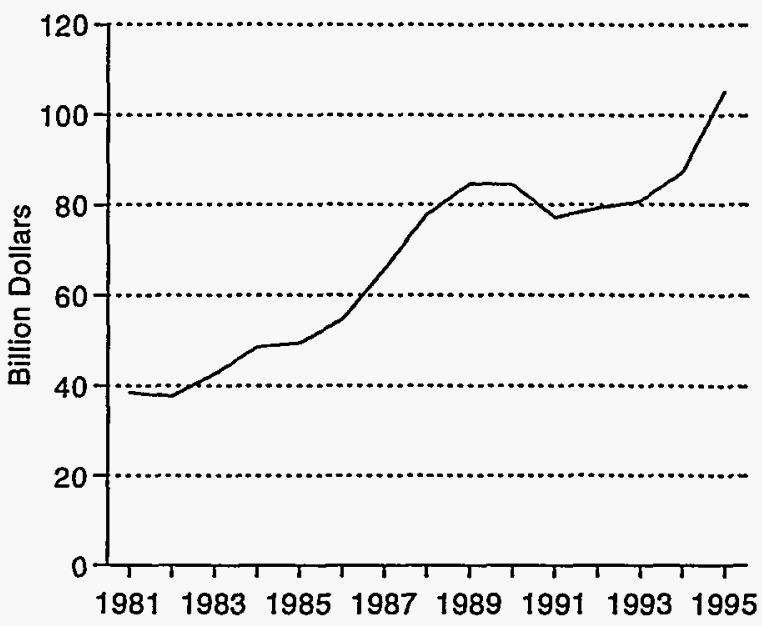

Source: Energy Information Administration, Office of Coal, Nuclear, Electric and Alternate Fuels. Derived from stock market analysis data sources, including Value Line Ratings and Reports (New York, NY: Value Line Publishing, Inc., December 12, 1990), more recent Value Line reports, and company annual reports.

The forest products industry comprises, at one end of the scale, a multitude of small and medium-sized businesses and, at the other, about two dozen extremely large international corporations. Some of these are conglomerates, also doing business in such enterprises as container manufacturing, chemicals, real estate, financial services, automotive components, and many other businesses. The American Forest \& Paper Association (AFPA) reports total industry employment of approximately 1.4 million people and total production

\footnotetext{
${ }^{18}$ H. Shapouri, J.A. Duffield, and M.S. Graboski, Estimating the Net Energy Balance of Corn Ethanol, U.S. Department of Agriculture, Economic Research Service, Agricultural Economic Report No. 721 (Washington, DC, July 1995).

${ }^{19}$ University of Washington, College of Forest Resources, web site weber.u.washington.edu (August 8, 1996).

${ }^{20}$ The profile included companies who were involved in primary paper and forest product manufacturing. For instance, companies whose primary business was package and container manufacturing were not considered. Such companies, known as "converters" are customers for and users of primary products such as wood pulp. However, the net sales data reported for the 25 largest companies also includes revenues from corporate divisions who are involved in converting operations.
} 
Figure 5. Industrial Production Index of the Paper and Forest Products Industry, 1947-1995

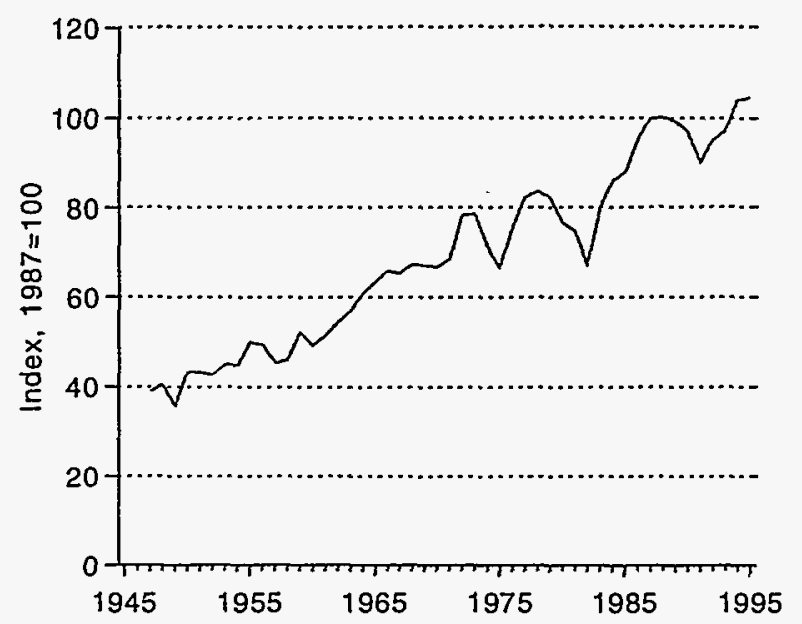

Source: Board of Governors of the Federal Reserve System, Economic Report of the President (Washington, DC, 1996), Table B49.

valued at more than $\$ 200$ billion a year (see box). ${ }^{21}$ In addition to their U.S. operations, many of these companies maintain Canadian subsidiaries, timber holdings, and leases. Net sales of a few of these companies exceed $\$ 10$ billion per year. Several forest product com-

The American Forest \& Paper Association estimates that the forest products industry in the United States, the largest in the world:

- Accounts for 8 percent of national manufacturing output

- Ranks among the top 10 manufacturing employers in 46 States.

The average single-family American home is about 2,000 square feet in size and can contain on the order of 16,900 board feet of lumber and up to 10,000 square feet of panel products.

Source: American Forest \& Paper Association, Quick Facts About America's Forest \& Paper Industry (Washington, DC, Summer 1995). panies owned and headquartered in Canada are not included in this report. Nevertheless, the industry is to a large extent North American in character and is frequently treated as such by market behavior models. ${ }^{22}$

It is not uncommon for large American forest and paper companies to maintain both joint and whollyowned plant operations and timber resources in foreign countries, located in almost any temperate or tropical part of the world. Several companies report whollyowned or joint-venture facilities and plantations in Latin America. ${ }^{23}$ Plantations are located in Brazil, New Zealand, and other forested areas of the world. Eucalyptus is a hardwood, for instance, imported into the United States for wood products and chemicals or feedstocks. Quite a few U.S. companies maintain overseas sales offices in Europe and Asia. Some report strong market shares in finished goods in these areas (although sales have declined in some cases with unfavorable local economic conditions). U.S. products are sometimes exported under original brand names, or they may bear regionally adopted foreign labels. The products are sometimes physically modified to the taste and needs of destination markets. The current profile includes only U.S.-based companies; however, statistics, as reflected in Figure 5, are based on total corporate activity, which includes foreign sales.

The population of businesses in the U.S. forest products industry numbers from as many as several hundred in some States to more than a thousand in a few. Even though comprehensive survey-based data are not available from which a complete picture of the small and medium business segment of the industry can be drawn, an approximation of their combined market strength can be found in the arithmetic difference between the AFPA estimate of total industry sales and the sales of the subgroup of the largest companies. This exercise indicates that the recent annual product output of the small and medium segment is in the neighborhood of $\$ 100$ billion, or nearly as large in aggregate as the combined sales of the 25 largest corporations. This is an important factor, which is reflected in the broad employment and diverse company characteristics of the forest products industry, as compared with those of more monolithic industries.

\footnotetext{
${ }^{21}$ American Forest \& Paper Association, QuickFacts About America's Forest \& Paper Industry (Washington, DC, Summer 1995).

${ }^{22}$ In considering general wood utilization and supply, some analyses do not separate U.S. and Canadian markets. This is the case for the North American Wood Energy Model utilized by the U.S. Forest Service and the Forest Products Laboratory.

${ }^{23} \mathrm{~A}$ recent EIA publication reports (a) increased foreign investment by American (and other) companies in world markets as a result of a trend toward globalization of business and the privatization of formerly state-run or state-controlled businesses and widespread liberalization of property laws. Broad regional adoption of free market economics in Latin America has contributed to the trend in business globalization. See Energy Information Administration, Privatization and the Globalization of Energy Markets, DOE/EIA-0609 (Washington, DC, October 1996).
} 
Many very large companies, in spite of-or because of-their size, are not completely self-sufficient in their fiber and timber needs. As a result, they represent a large, although sometimes cyclical, ${ }^{24}$ market for other companies, both within their own classification and smaller. It is sometimes in the self-interest of forest product businesses of all sizes to specialize, differentiate their products in some economically favorable way, or tailor their production to niche markets, and they frequently do so. The result is remarkable in that, while forest product companies share many common characteristics, they often have a variety of distinct "personalities" probably not found in less diverse industries. $^{25}$

Some industry subgroups and corporate divisions are involved in the supply of basic commodities such as rough lumber or the wood chips used for pulpwood or boiler fuel. Sawmill and chip mills are examples. Other industry subgroups and corporate divisions operate plants that deal in value-added products such as refined commodities and finished products. Examples of the products they make include dimension lumber, flooring, sheet stock (i.e., plywood and particle board), newsprint, and wood pulp.

The diversity of the forest products industry is reflected in its wide range of manufacturing specialization. One of many possible examples is "chip-n-saw" mills, which provide a market for trees larger than those usually ground into pulpwood but too small for saw timber. These mills process timber from trees that measure between 6 and 14 inches in diameter by removing the rounded outer layer of a log, then sawing the remaining rectangular inner section into lumber. ${ }^{26}$

Wood pulp, an example of a commodity product manufactured by the paper industry, may be used by a company's downline manufacturing operations or sold to others, referred to as "converters." Wood pulp varies in finished moisture content and can be repulped or directly processed. Converters manufacture a vast array of products from more basic paper products, including finished and coated papers, envelopes, shipping cartons, food containers, and paper bags. In almost analogous fashion, saw logs and dimension lumber are made into a large variety of structural components, building materials, furniture, and wood components. Forest residues, sawdust, mill scraps, and waste are likewise used for these purposes. Figure 6 illustrates the transformation of raw wood by manufacturing to a few of the thousands of finished wood products.

Forest product companies are active not only in all the manufacturing operations illustrated in Figure 6 but in hundreds of others as well. These processes have specialized energy requirements, and some produce as well as consume energy. The nature of wood energy generation and consumption in the forest products industry is integrally linked to the characteristics of these operational processes. There is a close relationship between rate of utilization of wood and residues for energy and plant output levels. Consequently, changes

Figure 6. Timber to Finished Product

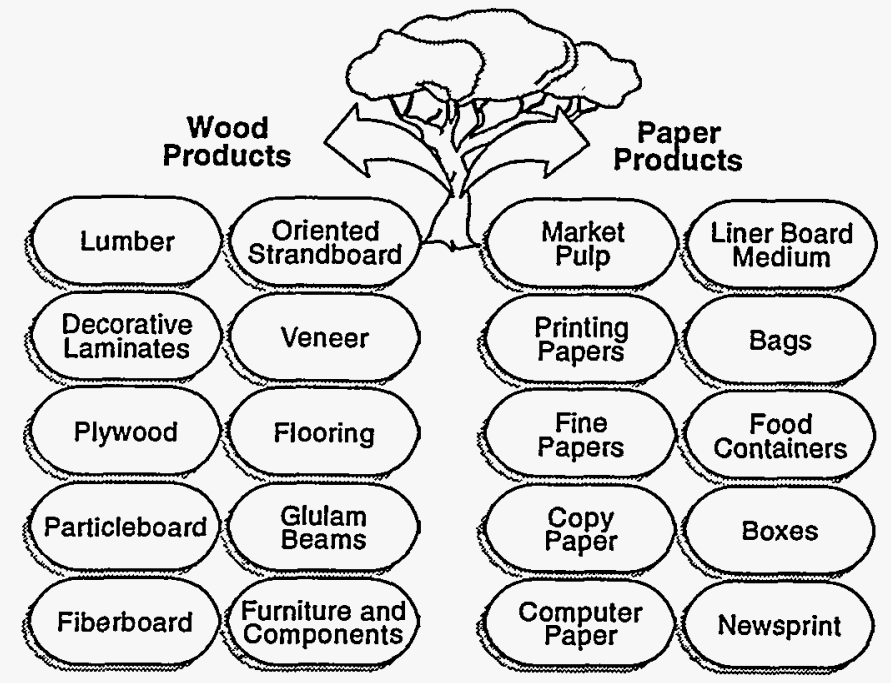

Source: Energy Information Administration, Office of Coal, Nuclear, Electric and Alternate Fuels (1996).

\footnotetext{
${ }^{24}$ Building materials and lumber (due in part to the effect of housing starts) tend to reflect the general economy, as do some commodity paper industry products (i.e., wood pulp). Other lines, such as tissue products and products used for remodeling projects, are less cyclical. Interest rates have an impact on construction starts and therefore on the sale and manufacturing levels of many timber products.

${ }^{25}$ Very large paper and forest product companies are frequently both vertically, horizontally, and resource integrated. This means, among other things, that they not only supply raw materials to themselves, they may also operate their own transportation and distribution organizations for their finished products. They may also be engaged in totally unrelated businesses. Some large companies do not produce enough fiber raw material to serve their own needs and are net purchasers. Others supply more than they use and are net sellers. Nevertheless, large companies still differ, widely in some cases, in their product mix, degree of integration, market share for given products, and orientation with respect to commodity or specialty product output. Almost all companies of medium or large size produce basic commodity products of some type but employ the strategies of commodity upgrading and product differentiation to create higher valued products.

${ }^{26}$ North Carolina Cooperative Extension Service, "Understanding Forestry Terms-A Glossary for Private Landowners," Woodland Owner Note 26, web site www.ces.ncsu.edu (July 24, 1996).
} 
in basic processes or in the kinds of products manufactured may affect wood and wood byproduct fuel consumption. ${ }^{27}$ Several factors, discussed below, have historically affected supply, demand, and energy consumption and generation. These are only a few of the many aspects of this complex and diverse industry and do not compose a comprehensive list of factors.

\section{Timber and Fiber Supply Factors in the Forest Products Industry}

There is evidence that a fair amount of differentiation, specialization, acquisition, and divestiture has taken place in the forest products industry over the past decade. Some of these actions are a result of corporate strategies to avoid or ameliorate the effects of oversupply or undersupply of timber and wood commodities for companies that are buyers, or to lessen the pain of low product prices during unfavorable market conditions for companies that are sellers.

Wood shortages have occurred due to factors such as constriction of available timber supply for environmental reasons; oversupply has occurred for reasons such as increased exports from other countries and peaking production related to capital investment cycles (discussed below). In general, commodity wood product price levels closely track these factors. However, there are indicators that fuelwood price and availability are not as directly affected by them as they are by the general market.

Today, extensive manufacture of recycled-content paper and wood products make recovered paper an important component of fiber supply (see box). A waste industry poll of State recycling programs indicates that recycledcontent office paper is the most widely purchased recycled product. State-mandated content levels range from 8 percent to 50 percent. ${ }^{28}$

Company strategies for coping with fiber supply shortages have included:

- Greater utilization of small-diameter trees and slash, not previously considered commercially viable, for wood chips, made possible by the advent of portable chipping machinery
According to the American Forest \& Paper Association:

- In 1994 the paper industry used 40 percent recovered paper in its products.

- A goal of using 50 percent recovered paper has been set for the year 2000 .

- Americans recycle enough paper daily to fill 15 miles of boxcars (in 1994, more than 39 million tons of paper and paperboard, or 297 pounds per capita).

- In 1993, recovered and reused products, such as recycled paper and particleboard, replaced 13.6 million tons of wood.

Source: American Forest \& Paper Association, Quick Facts About America's Forest \& Paper Industry (Washington, DC, Summer 1995).

- Sàle of plants and restricted timberland in environmentally sensitive regions

- Acquisition of plants or timberland in regions, such as the South, where timber resources are more plentiful than they are in some other regions (this is not always straightforward: while 41 percent of all timberland is in the South, ${ }^{29}$ the number of threatened or endangered species in the United States increased from 197 in 1989 to 728 in 1993, concentrated mainly in the Southeast and Southwest; ${ }^{30}$ nevertheless, it seems clear that a degree of industrial fiber supply and production capacity has migrated to the South ${ }^{31}$ )

- Swaps of more environmentally sensitive land for less environmentally sensitive land with the Federal and State governments and environmental groups

- Long-term supply contracts with smaller companies and private landowners

- Purchase of timberland or timber supply in other countries (sale and acquisition transactions for over 1 million acres were reported by one company in $\left.1995^{32}\right)$.

\footnotetext{
${ }^{2}$ Black liquor, a byproduct of papermaking, is a good example of this relationship. If output of wood pulp goes down at a given plant, less black liquor is recovered for fuel.

${ }^{28}$ Waste Age (August 1996), p. 40.

${ }^{20}$ U.S. Forest Service, Forest Resources of the United States, 1992, General Technical Report RM-234 (September 1993 ), Table 1.

30U.S. Forest Service, RPA Assessment of the Forest and Rangeland Situation in the United States-1993 Update, Forest Resources Report No. 27 June 1994), p. 4.

${ }^{31}$ Indications of this are reflected in the annual reports of some companies. The author consulted Dan Brandon of Morbark Corporation, a manufacturer of timber processing and handling equipment, in a telephone conversation on August 3, 1996, regarding this issue. Mr. Brandon confirmed that a certain amount of relocation to the South had occurred.

${ }^{32}$ Diamond Occidental Forest Inc., reported on page 41 of the annual report of the James River Corporation, which holds a 77-percent ownership interest.
} 
Wildfires were a serious problem during 1996. The National Interagency Fire Center in Boise, Idaho, reported that by September 1996, 85,313 wildfires had destroyed about 5.4 million acres of brush and forest land, mainly in the West and Alaska-more than 2.5 times the 5-year average of nearly 2 million acres a year. ${ }^{33}$ The effect on fiber supply is not yet known.

Fiber supply situations also extend to recycled ${ }^{34}$ wood and paper commodities and products. Broad fluctuations in price and supply have occurred at times. Periods of serious oversupply have been reported for several varieties of recovered raw materials during the past 5 years, resulting in some business failures. An undersupply condition occurred, however, between June 1994 and May 1995, affecting old corrugated containers and double-lined kraft, which are used heavily by mills that produce recycled paperboard. Their costs increased during the period from $\$ 85$ to $\$ 110$ per ton and from $\$ 195$ to $\$ 270$ per ton, respectively. In order to ensure a steady source of supply, at least one paperboard manufacturer acquired several recycling centers. ${ }^{35}$

\section{Production Output Factors in the Forest Products Industry}

Historically, the paper and allied products manufacturing group, composing about two-thirds of the forest products industry, has been highly capital-intensive. The AFPA reports that the ratio of investment in plant and equipment to employment is $\$ 100,000$ per employee, over twice that of overall U.S. manufacturing. ${ }^{36}$ Profits of many companies are lean during poor economic conditions and more profitable during, or slightly after, periods of a healthy economy. Increased capital investment activity often follows on the heels of profitability. Then, as capital improvements come on line, industry manufacturing capacity and output begin to increase, and oversupply of commodity products may sometimes occur. Low profitability may then result from market gluts.
The same effect has resulted from the intersection of unfavorable market forces. The following is an example. Newsprint manufacturers built new plants during the $1980 \mathrm{~s}$ in response to growing demand for paper with more recycled content. As new mill production peaked in the early 1990s, global economic growth declined. Prices for newsprint fell drastically from the late 1980s, as newspaper companies adjusted product output, until turning around and nearly doubling by $1995 .^{37}$

\section{Demand Factors in the Forest Products Industry}

In its analysis supporting the National Wood Energy Model (NAWEM), the U.S. Forest Service states that many traditional wood energy supply sources are not used in the production of timber products, such as saw logs, veneer logs, or pulpwood. ${ }^{38}$ Much available wood energy supply is derived from "nongrowing" timber stock, i.e., "slash" and wood waste recovered from other sources. Therefore, demand for woodfuel does not compete directly with demand for lumber, panels, and paper, which are derived primarily from commercial timber (see also Chapter 6 of the Renewable Energy Annual 1995 for a discussion of wood residue supply sources). The model also considers that demand for woodfuel may be slow to respond to changes in wood energy or fossil fuel prices. ${ }^{39}$

Other factors supporting this market behavior are as follows:

- Residential sector woodfuel usage does not add in any direct way to industrial demand.

- Privately held timberland acreage is four times larger than industrial. ${ }^{40}$

- A poll in the Southeast indicated that approximately 60 percent of logs and "splitwood" used by residences was cut by households, 10 percent was given to households, and about 30 percent was purchased. ${ }^{41}$

\footnotetext{
${ }^{33}$ Volunteers in Technical Assistance, "NICC Incident Management Report," web site www.vita.org/disaster/wildfire/9608 (August 31, 1996).

${ }^{34}$ Finished products are labeled recycled. It avoids confusion to refer to the wood or paper raw material supplies that are used to make them as "recovered" or "reclaimed."

${ }^{35}$ Republic Gypsum Corporation, 1995 Annual Report.

${ }^{36}$ American Forest \& Paper Association, Quick Facts About America's Forest \& Paper Industry (Washington, DC, Summer 1995).

${ }^{37} \mathrm{~F}$. Kramer, in The Virginian Pilot (September 27, 1995), p. D3.

${ }^{38}$ Saw logs, veneer, pulpwood, and other products using higher quality timber compete with each other for supply on a more active basis.

${ }^{39}$ K. Skog, U.S. Forest Service, Forest Products Laboratory, "Projected Wood Energy Impact on U.S. Forest Wood Resources," in Proceedings of the First Biomass Conference of the Americas: Energy, Environment, Agriculture, and Industry: 1993, Burlington, VT, August 30September 7, 1993 (Golden, CO: National Renewable Energy Laboratory, 1993), Vol. 1, pp. 18-32.

${ }^{40}$ D.S. Powell et al., U.S. Forest Service, Forest Resources of the United States, 1992, General Technical Report RM-234, pp. 52-55.

${ }^{41}$ Southeastern Regional Biomass Energy Program, Residential Fuelwood Consumption in the Southeastern United States, TVA/NFERC/BIO92/5 (August 1991), p. 26.
} 


\section{Changes in Process}

Electricity and thermal energy (in the form of direct heat, hot air, hot water, and steam) are consumed in large quantities by forest product processes. Electricity is required in large quantities to power motors which drive process machinery, pumps, air compressors, hydraulic systems, and handling systems, including saws, planers, edgers, joiners, knives, conveyors, extruders, printing and forming, presses, and railed platforms.

Current papermaking technology uses either chemical or mechanical processes, or both. In either process, cell fibers are separated (delignified) in manufacturing pulp. The cell structure partially collapses in delignification, and the resulting fiber particles are further processed and formed into paper. The recent manufacturing trend is toward utilization of mechanical processes. A comparison of the characteristics of each process follows: ${ }^{42}$

\begin{tabular}{l|l}
\hline \multicolumn{1}{c|}{ Mechanical } & \multicolumn{1}{c}{ Chemical } \\
\hline $\begin{array}{l}\text { Higher yields (above 90 } \\
\text { percent) }\end{array}$ & $\begin{array}{l}\text { Pulp yields of } 40 \text { to } 50 \\
\text { percent }\end{array}$ \\
$\begin{array}{l}\text { Plants less expensive to } \\
\text { build }\end{array}$ & $\begin{array}{l}\text { Plants more expensive to } \\
\text { build }\end{array}$ \\
$\begin{array}{l}\text { Higher energy require- } \\
\text { ment }\end{array}$ & Better pulp quality \\
$\begin{array}{l}\text { Lower combustible by- } \\
\text { product levels }\end{array}$ & $\begin{array}{l}\text { Higher combustible by- } \\
\text { product levels }\end{array}$ \\
\hline
\end{tabular}

Mechanical pulping requires a greater expenditure of energy than chemical pulping and does not generate black liquor, a byproduct that can be burned for energy (except when it is produced by chemical pretreatment). Some energy is required by chemical processes, however, to recover pulping liquor, thereby subtracting from net energy produced by the system. As a precondition to combustion in such boiler systems, pulping liquor is "dewatered" to achieve a near-solid combustible state.

After delignification, the pulp is bleached to eliminate impurities and achieve brightness in some paper products. This is required for white paper products and high-grade paper and packaging. The most common bleaching processes used traditionally in papermaking employ chlorine. Newsprint, unbleached paperboard, and other lower grade products do not require bleaching. Energy is expended in the recovery of pulping and bleaching chemicals and the cleanup of waste water.

AFPA data show woodfuel use by the pulp and paper industry at a plateau of just under 400 trillion Btu per year for the last decade. At the same time, energy from pulping liquor has climbed steadily to a current level of about 1.1 trillion Btu. ${ }^{43}$ Several conditions may account for this consumption pattern:

- Scarcity and cost of mature timber with high bark yield

- Increased cultivation of short-rotation pulp timber

- Increase in the pulp and paper industry's consumption of natural gas ${ }^{44}$

- Possible increase in the rate of harvesting of precommercial timber to improve longer term timber yield or to replace marginal timber stands with fastgrowing, improved tree varieties.

To the extent that mechanical pulping may increase in prevalence, byproduct generation and consumption of pulping liquor could be expected to decrease. Another chemical method, sulfite pulping, leaves residual lignin in the finished product. A new technology, "biopulping," shows great environmental promise. The pretreatment of wood chips with the wood-reducing fungus associated with biopulping has reduced residual lignin in sulfite pulping by 50 percent (by conversion to cellulose) in research-scale projects. ${ }^{45}$ Lignin converted to cellulose in this process becomes usable pulp and is not available as a combustible byproduct; however, the process reduces the electricity requirement by up to 43 percent.

Other factors in the forest products industry at large can increase energy yield relative to a given woodfuel consumption rate. These include combustion system (refractory and boiler) improvements or upgrades, use of heat exchangers to capture residual process and boiler heat, and use of waste heat for drying wood raw material and woodfuel.

\footnotetext{
${ }^{42}$ T.K. Kirk et al., U.S. Forest Service, Forest Products Laboratory, Biopulping: A Glimpse of the Future, FPL-RP-523 (December 1993 ), p. 1.

${ }^{43}$ American Forest \& Paper Association, Fact Sheet on 1994 Energy Use in the U.S. Pulp and Paper Industry (Washington, DC, March 27, 1996).

44 American Forest \& Paper Association, Fact Sheet on 1994 Energy Use in the U.S. Pulp and Paper Industry.

${ }^{45}$ Pacific Northwest Pollution Prevention Research Center, web site pprc.pnl.gov (September 27, 1996).
} 


\section{Energy Profiles of Primary Forest Product Processes}

It has been stated that wood products compose 47 percent of the industrial raw materials made in the United States, while they consume only 4 percent of manufacturing energy. ${ }^{46}$ Wood products can be classified into five very rough, primary groups: sawed lumber, glued engineered wood products, pulpwood, fuelwood, and other products. The first three of these are manufactured by sawmills; plywood, particle, and strand product mills; and pulp, paper, and paperboard mills. Some of the energy characteristics of these mills are discussed below.

\section{Sawmills}

Table 7 shows the energy and raw material input of a modern sawmill. Representative energy values for the fuel products generated by this hypothetical sawmill are given in the footnotes of the table and adjusted to a 12-percent wet basis moisture content to enable an approximate comparison to the one oven-dry ton of input wood. If the energy values of the fuel products are then added, it can be seen that the total exceeds the energy used by the sawmill by about 10 percent. If the sawdust in the "Products" column of the table were used, ${ }^{47}$ the value of the fuel products produced by the sawmill would exceed that consumed in its operation by nearly 30 percent.

\section{Plywood, Particle, and Strand Product Mills}

Plywood, particle board, strand board, and laminated beams are manufactured in the engineered wood prod- uct industry. Plywood is made by sandwiching veneered wood sheets together with glue and forming the resulting panel to dimension specifications under heat and pressure. Strand board and particle board are made by forming strands of wood fiber or particles with adhesives under heat and pressure. Drying operations are by far the most energy-intensive aspect of panel manufacturing. In some processes, wood or wood fibers must be dried to an acceptable level in order for the adhesive to bond to them properly. In other processes, such as conveyor drying of strand board panels, heat is applied for the purpose of both forming and driving moisture out of the panel.

Glued, laminated beams, or "glulams," are air-cured and require no process energy in manufacture other than when radiofrequency energy is applied to set connectors and end plates into the components. This is a low-energy process and represents only a minor energy consumption factor. The engineered wood product industry uses waste wood from timber processing and mill scraps from manufacturing extensively to produce much of the energy used in drying and other processes. This industry has realized significant energy savings in recent years through modernization programs that have minimized material waste, improved process control, and upgraded energy production systems.

\section{Pulp, Paper, and Paperboard Mills}

According to the AFPA, average energy used to make a ton of pulp for paper or paperboard in 1994 was 26 million Btu. ${ }^{48}$ Historically, the overwhelming majority of mills producing bleached pulp and white papers

Table 7. Energy and Raw Materials Inputs and Outputs of a Modern Sawmill

\begin{tabular}{c|lc}
\hline Initial Inputs & \multicolumn{1}{c|}{ Products } & \multicolumn{1}{c}{ Components of Fuel Output $^{-1}$} \\
\hline 1 oven-dry ton of wood & 0.56 ton lumber & 0.10 ton bark $^{\mathrm{a}}$ \\
113 kilowatthours of electricity & 0.25 ton pulp chips & 0.03 ton ends \\
$(2.25$ million Btu equivalent) & 0.15 ton fuel & 0.02 tons sanderdust $^{\mathrm{b}}$ \\
& 0.04 ton sawdust & \\
\hline
\end{tabular}

${ }^{a} 4,418$ Btu per pound at 50 percent wet basis moisture content, based on American Forest \& Paper Institute 1994 data, or $16,664,000$ Btu per ton adjusted to 12 percent wet basis (approximate equilibrium) moisture content. Oven-dry moisture level is in the range of about 0 percent to equilibrium level.

${ }^{b} 4,166$ Btu per pound at 50 percent wet basis moisture content, based on American Forest \& Paper Institute 1994 data for hogged fuel, or 15,551,360 Btu per ton adjusted to 12 percent wet basis (approximate equilibrium) moisture content. Oven-dry moisture level is in the range of about 0 percent to equilibrium level.

Approximately 8,700 Btu per pound on an oven-dry basis for an average of 12 common commercial tree species.

Source: Based on D.A. Tillman, The Combustion of Solid Fuels and Wastes (New York, NY: Academic Press, 1991 ), pp. 48-50.

\footnotetext{
${ }^{46}$ Engineered Wood Association, "Engineered Wood and the Environment," web site www.apawood.org (September 23, 1996).

${ }^{47}$ Sawdust is sometimes processed into pellet fuel or used in a variety of products, however in many cases, it remains unused and represents a waste problem. This example assumes an energy value of 10 million Btu per ton at 50 percent wet basis moisture content.

${ }^{48}$ American Forest \& Paper Association, Monthly Statistical Summary (Washington, DC, July 1996).
} 
used chlorine compounds in their bleaching processes. Some alternative processes substitute ozone in combination with other agents; however, ozone is expensive to manufacture. About 15 pounds of ozone is required for every ton of pulp bleached. A new technology developed and patented by Lawrence Berkeley Laboratory saves resources and lowers the cost of ozone production. Called the POZONE process, this method cleans up bleaching and pulping effluents by using yellow phosphorus and air while simultaneously producing ozone as a byproduct. ${ }^{49}$

As a rule, paper mills use the high-pressure steam produced by their boilers to power turbine generators, which produce most of the electricity they use. The lower-pressure, lower-temperature steam left over from this operation is then used in mill processes such as cooking and drying. To the extent that more efficient boilers, heat exchangers, and more modern control equipment are used when processes are updated or modified, energy can be saved. The AFPA reports that the average energy used to make a ton of pulp for paper or paperboard declined by 2.3 percent from 1993 to $1994 .{ }^{50}$

\section{Biopulping: New Biomass Technology on the Industrial Horizon}

The forest products industry is participating with the U.S. Department of Energy (DOE), Office of Industrial Technologies, in the "Industry of the Future" strategy. This involves the development of a vision and technology road map document known as "Agenda 2020," an agreement between DOE and the AFPA in November 1994. Related DOE activity includes cooperative research and development with biocatalysts and working with a number of companies, coordinated by Oak Ridge National Laboratory, to develop materials for improved efficien $y$ in kraft black liquor recovery boiler operations.

A 5-year research program between 1987 and 1992 conducted by the Biopulping Consortium ${ }^{51}$ evaluated several hundred strains of fungus for pretreatment of wood for pulping ("biopulping"). The consortium determined that two particular fungi (Ceriporiopsis subvermispora and Phanerochaete chrysosporium) demonstrated excellent ability to break down lignin in wood.

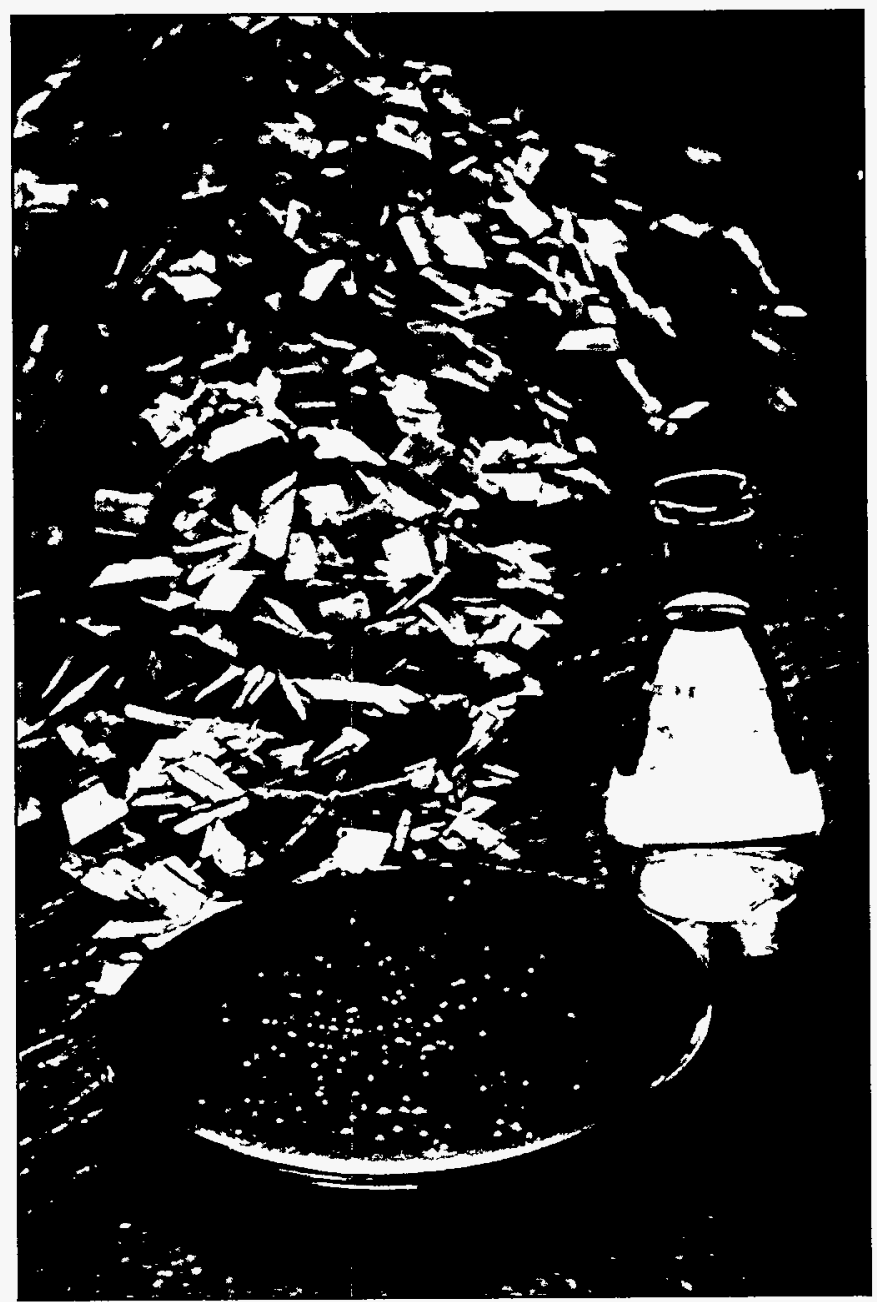

Wood is a major resource for bioconversion. Researchers at the National Renewable Energy Laboratory, Golden, $\mathrm{CO}$, are studying conversion of biomass and wastes through chemical processes.

The former of these naturally occurring fungi was effective in breaking down pine and aspen and the latter in breaking down aspen. A followup 4-year program was completed in 1996, and a 5-ton mill scaleup demonstration was successful.

This research ${ }^{52}$ showed that electrical energy requirements were reduced by 30 to 40 percent relative to mechanical pulping. A 50-ton commercial trial is pending. ${ }^{53}$ Microscopic analysis revealed that the rigid cell walls of wood relax and swell when pretreated in the biopulping process, permitting better yields of

\footnotetext{
${ }^{49}$ Lawrence Berkeley Laboratory, "Pulp Mills and White Paper: Bringing Down the Environmental Price," web site www.lbl.gov (October 28, 1996).

${ }^{50}$ American Forest \& Paper Association, Monthly Statistical Summary (Washington, DC, July 1996).

${ }^{51}$ The Biopulping Consortium is made up of the U.S. Forest Service, Forest Products Laboratory (Madison, WI); the University of Wisconsin; the University of Minnesota; and approximately 20 forest product companies. The biopulping project and the consortium originated as a research topic recommended to the Forest Products Laboratory by a joint committee of the American Paper Institute and the Technical Association of the Pulp and Paper Industries.

${ }^{52}$ U.S. Forest Service, Forest Products Laboratory, Biopulping A Glimpse of the Future, Research Paper FPL-RP-523 (December 1993).

${ }^{53}$ Per telephone conversation between Robert Lowe, EIA, and Dr. Masood Akhtar, Forest Products Laboratory (October 9, 1996).
} 
wood fiber and reducing pitch content in resulting wood pulp (pitch fouls papermaking machinery). Two weeks of residence time in bioreactors was shown to be sufficient with $P$. chrysosporium. Aspen subjected to biopulping achieved 80 percent brightness with peroxide bleaching and 60 percent, or newsprint level, with hydrosulfite bleaching - two methods in use commercially that are more environmentally friendly than chlorine bleaching.
The work of the Biopulping Consortium drew from about three decades of previous international research on the natural decay effects of white rot fungi on pine and other topics. When used in conjunction with chemical pulping, it was shown that most paper strength properties increased as a function of the extent of wood decay by these fungi. Laboratory-scale tests using this process and wood feedstocks have shown that yields of fermentable starch for making ethanol can be doubled. 



\section{Municipal Solid Waste Profile}

\section{Introduction}

The municipal solid waste (MSW) industry has four components: recycling, composting, landfilling, and combustion (Figure 7). The U.S. Environmental Protection Agency defines MSW to include durable goods, containers and packaging, food wastes, yard wastes, and miscellaneous inorganic wastes from residential, commercial, institutional, and industrial sources. ${ }^{54}$ It excludes industrial waste, agricultural waste, sewage sludge, and all categories of hazardous wastes, including batteries and medical wastes. More than 209 million tons of MSW was generated in 1994. Paper and paperboard accounted for 81.3 million tons ( 38.9 percent) of the total waste stream, yard wastes 30.6 million tons (14.6 percent), plastics 19.8 million tons ( 9.5 percent),

Figure 7. Chief Components of Municipal Solid Waste Management

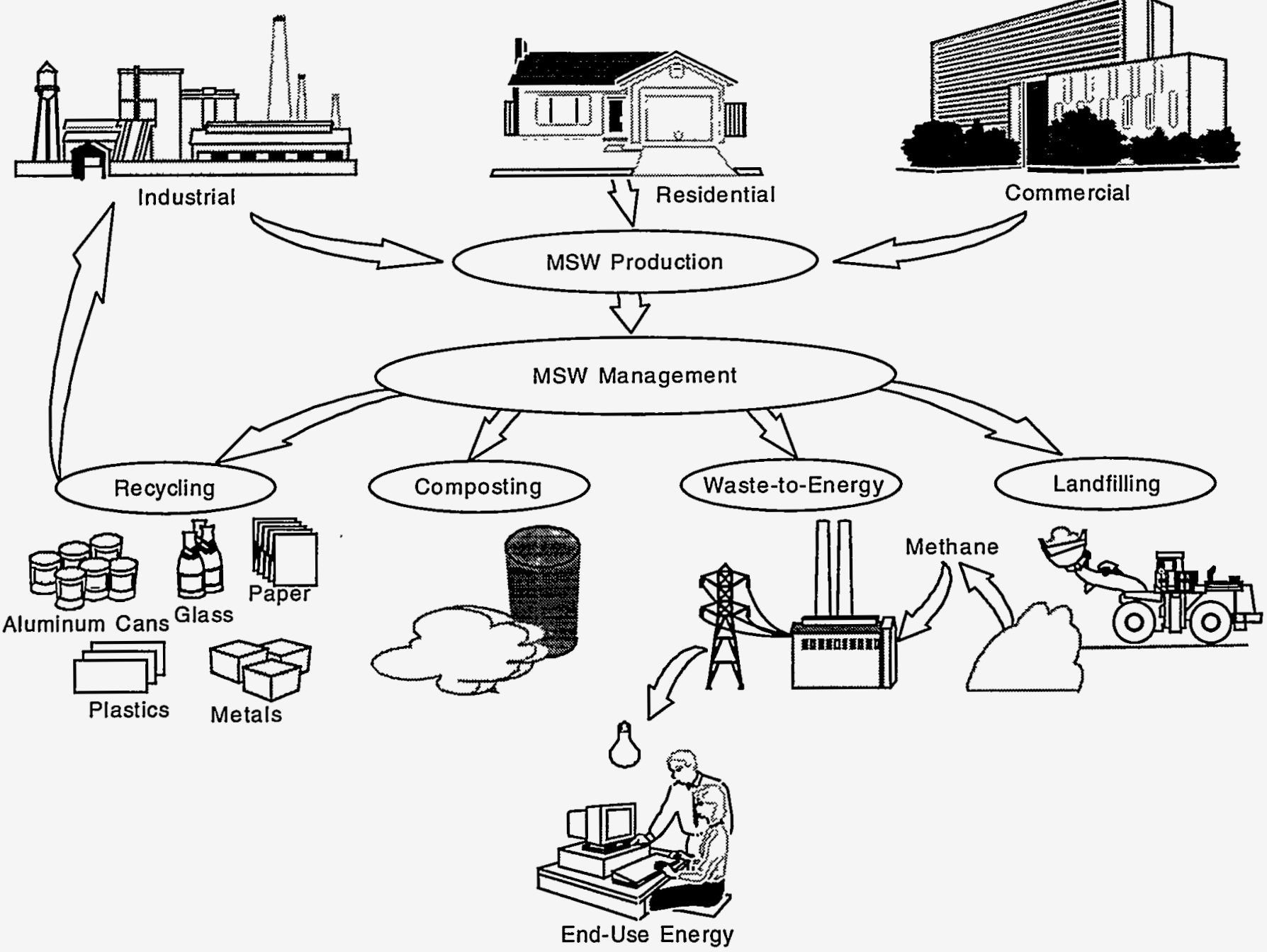

Source: Energy Information Administration, Office of Coal, Nuclear, Electric and Alternate Fuels (1996).

${ }^{54}$ U.S. Environmental Protection Agency, Characterization of Municipal Solid Waste in the United States: 1995 Update, EPA/530-S-96-001 (Washington, DC, March 1996). 
metals 15.8 million tons ( 7.6 percent), food 14.1 million tons (6.7 percent), glass 13.3 million tons ( 6.3 percent), and other 34.2 million tons (16.4 percent) (Figure 8).

Figure 8. Total U.S. Waste Generation Before Recycling, 1994

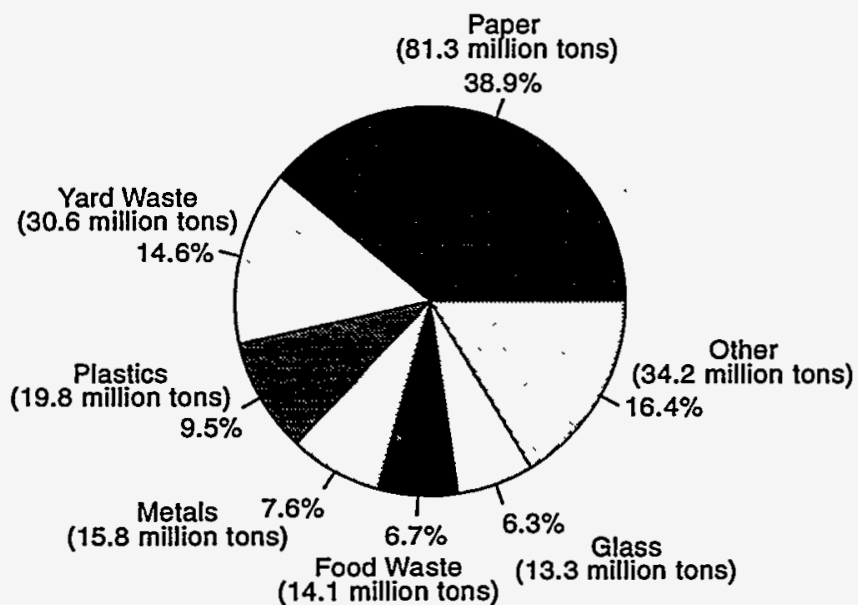

Source: U.S. Environmental Protection Agency, Municipal Solid Waste Factbook, database version 3.0 (Washington, DC, March 1996).

\section{Trends in Municipal Solid Waste Generation}

The generation of MSW has increased from 88 million tons in 1960 to 209.1 million tons in 1994. During that time, per capita generation of MSW increased from 2.7 pounds per person per day to 4.4 pounds per person per day (Figure 9). Per capita generation is expected to remain constant through 2000, when total MSW generation is expected to reach 223 million tons.

In 1960, approximately 30 percent (27 million tons) of MSW generated was incinerated, most without energy recovery or air pollution controls (Table 8 ). During the next two decades, combustion declined steadily, to 13.7 millions tons by 1980, as old incinerators were closed. Less than 10 percent of the total MSW generated in 1980 was combusted. With the enactment of the Public Utility Regulatory Policies Act of 1978 (PURPA) and the emergence of a guaranteed energy market, combustion of MSW increased to 31.9 million tons or 16 percent of generation by 1990. All of the major new waste-toenergy (WTE) facilities are designed with air pollution controls and have energy recovery. During the 1990s, the absolute amount of MSW combusted and converted into energy remained fairly constant, although the share declined slightly. By the year 2000, the amount of MSW combusted is expected to reach 34 million tons. ${ }^{5}$

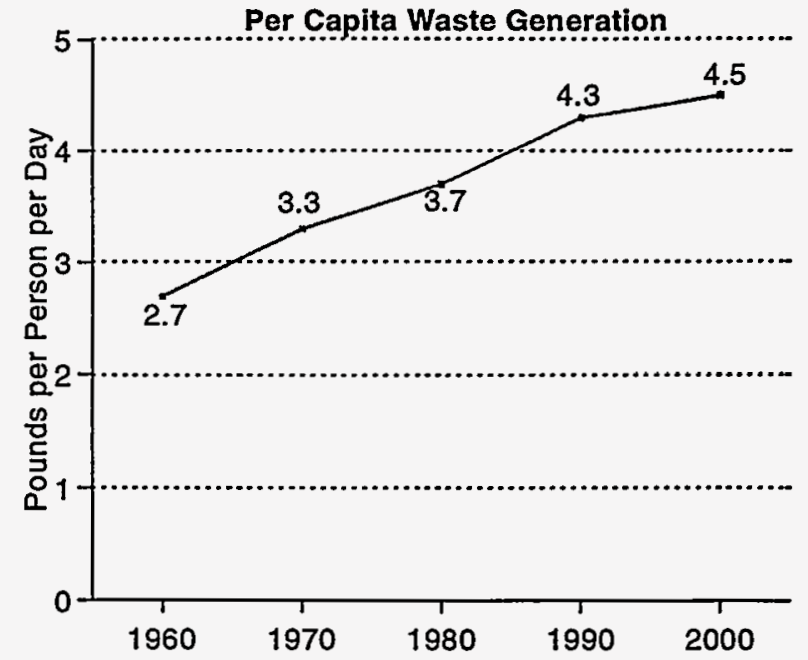

Figure 9. U.S. Waste Generation, 1960-2000

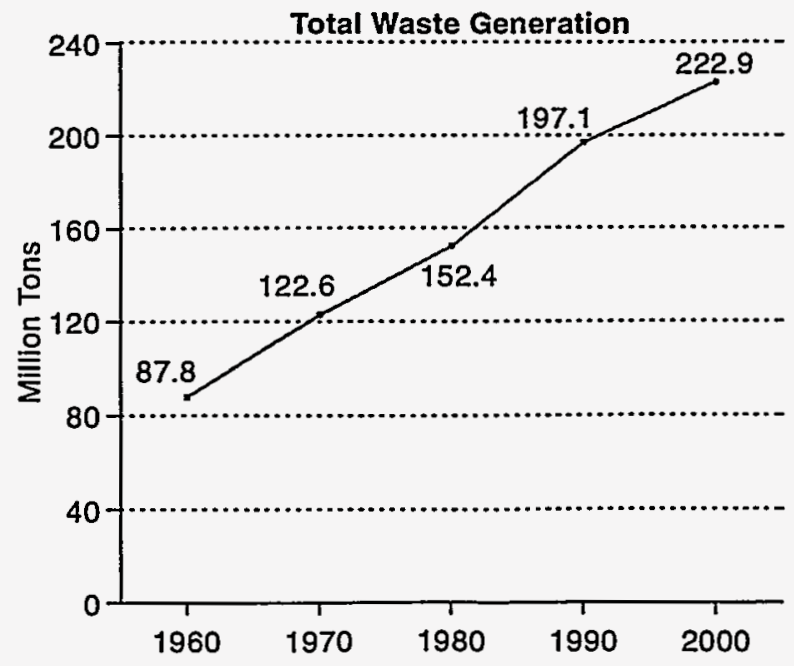

Source: U.S. Environmental Protection Agency, Municipal Solid Waste Factbook, database version 3.0 (Washington, DC, March 1996).

${ }^{55}$ U.S. Environmental Protection Agency, Characterization of Municipal Solid Waste in the United States: 1995 Update. 
Table 8. Historical and Projected U.S. Production of Municipal Solid Waste, Selected Years, 1960-2000 (Million Tons)

\begin{tabular}{|c|c|c|c|c|c|c|c|c|c|}
\hline Disposition & 1960 & 1970 & 1980 & 1990 & 1991 & 1992 & 1993 & 1994 & 2000 \\
\hline Combustion $^{\mathrm{a}}$ & 27.0 & 25.1 & 13.7 & 31.9 & 33.3 & 32.7 & 32.9 & 32.5 & 34.0 \\
\hline Recovery for Recycling and Composting & R5.6 & 8.6 & R14.4 & 32.9 & 37.3 & 41.5 & 45.0 & 49.3 & 66.9 \\
\hline Discards to Landfill & R55.3 & R89.5 & R124.3 & R132.3 & 126.2 & 128.8 & 129.0 & 127.3 & 122.0 \\
\hline Total Production $\ldots \ldots \ldots \ldots \ldots \ldots \ldots$ & 87.8 & R121.6 & R152.4 & R197.1 & 196.8 & 203.0 & 206.9 & 209.1 & 222.9 \\
\hline
\end{tabular}

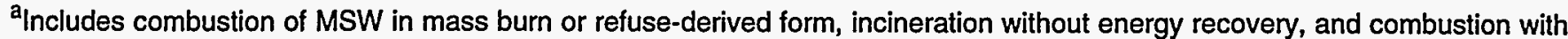
energy recovery of source-separated materials in MSW.

$R=$ Revised data.

Note: Totals may not equal sum of components due to independent rounding.

Sources: 1960, 1970, 1980, 1990, 1994, and 2000: U.S. Environmental Protection Agency, Municipal Solid Waste Factbook, database version 3.0 (Washington, DC, March 1996). This source has revised some of the historical data. 1991, 1992, and 1993: U.S. Environmental Protection Agency, Characterization of Municipal Solid Waste in the United States: 1995 Update, EPAV30-S-96001 (Washington, DC, March 1996).
}

\section{Waste-to-Energy Facilities}

As of the fall of 1996, there were 102 WTE facilities marketing energy in the United States. ${ }^{56}$ The number of facilities has declined by more than 10 percent during the past few years. Most of the WTE facilities in the United States are located in the East, where landfill space is the most scarce. WTE capacity has declined by approximately 2 percent over the last year or so, from almost 101,000 tons per day to approximately 99,000 tons per day.

\section{Type of Process and Capacity}

Generally, WTE facilities can be divided into two process types: mass burn and refuse-derived fuel (RDF). Mass burn facilities process raw waste; it is not shredded, sized, or separated before combustion. Very large items such as refrigerators or stoves and batteries/hazardous waste materials are removed before combustion. Noncombustible materials such as metals can be removed before or after combustion, but they are usually separated from the ash with magnetic separators. The waste is usually deposited in a large pit and moved to furnaces with overhead cranes.

Combusting waste usually reduces its volume by approximately 90 percent. The remaining ash is buried in landfills. The ash is divided into two categories: bottom ash and fly ash. Bottom ash is deposited at the bottom of the grate or furnace. Fly ash is composed of small particles that rise during combustion and are removed from the flue gases with fabric filters and scrubbers. Fly ash is usually considered to be the more significant environmental problem.
Waste is preprocessed at RDF facilities. Noncombustible materials are removed, increasing the energy value of the fuel. The extent to which noncombustible materials are removed varies. Most systems remove metals with magnetic separators; glass, grit, and sand may be removed through screening. Some systems utilize air classifiers, trommel screens, or rotary drums to further refine the waste.

Modular facilities are small mass burn facilities; they are usually prefabricated and shipped fully assembled or in modules to the construction site. Mass burn waterwall facilities are usually custom-designed and constructed at the site. Waterwall furnaces contain closely spaced steel tubes that circulate water through the sides of the combustion chamber. The energy from the burning waste heats the water and produces steam. Some waterwall facilities also use rotary combustors to rotate the waste, resulting in more complete combustion.

The overall majority of WTE facilities employ mass burn processes (Figure 10). Of the 101 facilities reporting the type of process employed in 1996, 86 were mass burn facilities and 15 were RDF facilities. Two of the mass burn facilities codisposed their waste with sludge. Although only 22 percent of the facilities were of the smaller modular type, 6 of the 13 facilities located in the North Central region were modular (Table 9). Over half of the facilities were of the mass burn, waterwall type. More than 40 percent of the facilities are located in the Northeast and another one-third in the South. Only 22 percent are located in the West and North Central regions, where landfill space is relatively less scarce.

\footnotetext{
${ }^{56}$ Data based on Governmental Advisory Associates, Inc., Municipal Solid Waste Combustion in the United States: 1996-97 Yearbook, Directory, and Guide (Westport, CT, 1997).
} 
Figure 10. Number of Facilities Performing Waste-to-Energy Operations by Process Type, 1996

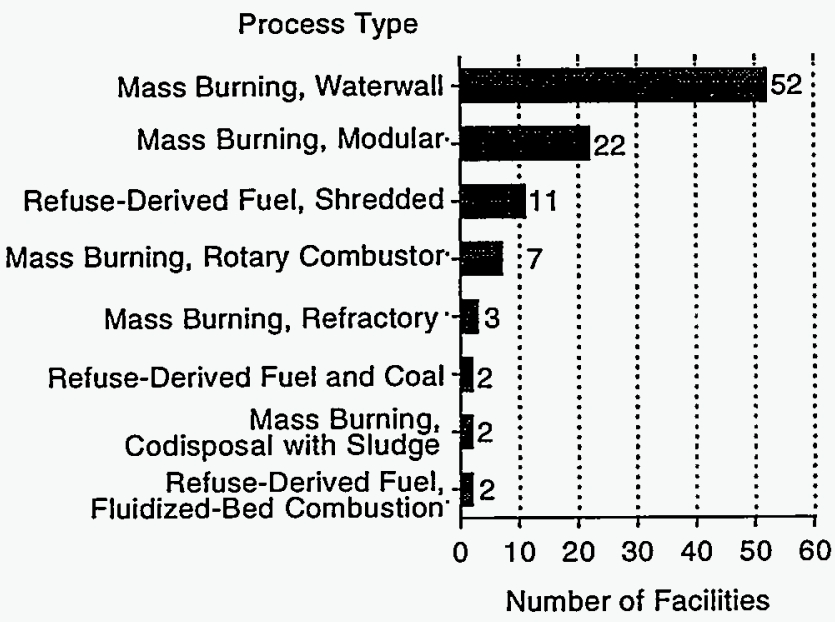

Note: One reporting facility did not list type of process.

Source: Derived from Governmental Advisory Associates, Inc., Municipal Waste Combustion in the United States: 199697 Yearbook, Directory, and Guide (Westport, CT, 1997).

The average capacity of U.S. WTE facilities is almost 1,000 tons per day (Table 10). RDF facilities, on average, have more than twice the capacity of mass burn facilities (almost 1,900 tons per day versus 850 tons per day). The facilities in the Northeast and South regions have an average capacity greater than 1,000 tons per day. The average capacity of the facilities in the North Central and West regions is between 700 and 800 tons per day (Table 11). Modular facilities are by far the smallest, ranging from an average of 89 tons per day in the North Central region to 256 tons per day in the Northeast (Table 12).

\section{Primary Energy Form}

Over 80 percent of the 102 facilities produce electricity. Twenty of the 84 facilities that produce electricity cogenerate steam and electricity (Figure 11). Only 18 of the facilities produce just steam; 12 of those facilities are modular. None of the RDF facilities produce steam only, compared with more than half of the modular facilities, most of which are older facilities.

In recent years most of the installations have generated electric power. The guaranteed market for electricity under PURPA minimizes the financial risk for facilities generating electricity. This condition could change if electricity prices drop as a result of restructuring in the electric utility market.

Figure 11. Energy Production from Waste-to-Energy Facilities by Type of Energy, 1996

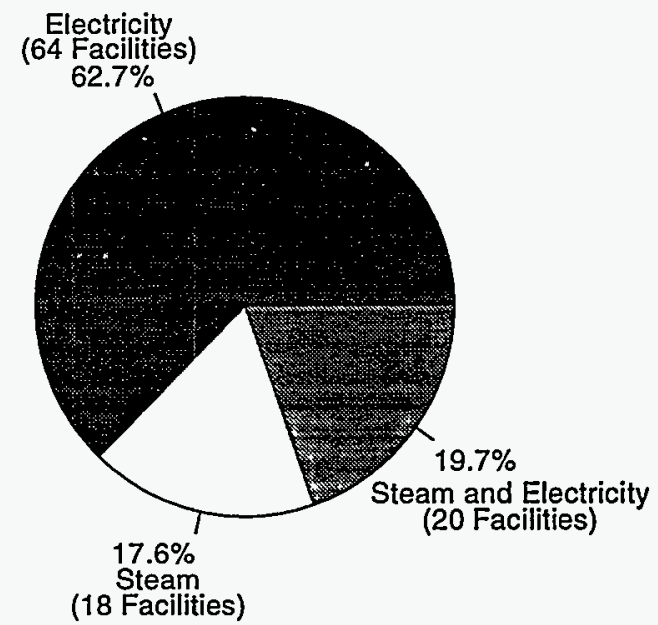

Source: Derived from Governmental Advisory Associates, Inc., Municipal Waste Combustion in the United States: 199697 Yearbook, Directory, and Guide (Westport, CT, 1997).

Table 9. Waste-to-Energy Facilities by Type of Process and Region, 1996

\begin{tabular}{|c|c|c|c|c|c|}
\hline \multirow[b]{2}{*}{ Type of Process } & \multicolumn{5}{|c|}{ Number of Facilities } \\
\hline & Northeast & South & North Central & West & Total \\
\hline Mass Burning, Modular & 5 & 10 & 6 & 1 & 22 \\
\hline Mass Burning, Waterwall .... & 27 & 16 & 4 & 5 & 52 \\
\hline Mass Burning, Refractory & 1 & 1 & 0 & 1 & 3 \\
\hline Mass Burning, Rotary Combustor.... & 5 & 2 & 0 & 0 & 7 \\
\hline All RDF Processes & 5 & 5 & 3 & 2 & 15 \\
\hline Total $\ldots \ldots \ldots \ldots \ldots \ldots \ldots \ldots \ldots$ & 43 & 34 & 13 & 9 & 99 \\
\hline
\end{tabular}

RDF = refuse-derived fuel.

Note: One facility did not list a process type. Two facilities that listed process as mass burning codisposal with sludge were not included in the totals. Information shown in this table includes only facilities that market energy.

Source: Derived from Governmental Advisory Associates, Inc., Municipal Waste Combustion in the United States: 1996-97 Yearbook, Directory, and Guide (Westport, CT, 1997). 
Table 10. Design Capacities of Waste-to-Energy Facilities by Process Type, 1996 (Tons per Day)

\begin{tabular}{c|c|c|c|c}
\hline Type of Process & Mean & Minimum & Maximum & Number of Facilities \\
\hline Mass Burning $\ldots \ldots \ldots \ldots \ldots \ldots$ & 849.8 & 24 & 3,150 & 86 \\
All RDF Processes $\ldots \ldots \ldots \ldots \ldots$ & $1,873.8$ & 294 & 4,000 & 13 \\
All Facilities $\ldots \ldots \ldots \ldots \ldots$ & 965.4 & 24 & 4,000 & 99 \\
\hline
\end{tabular}

RDF $=$ refuse-derived fuel.

Note: Two facilities did not list design capacities, and one facility did not list a process type.

Source: Derived from Governmental Advisory Associates, Inc., Municipal Waste Combustion in the United States: 1996-97 Yearbook, Directory, and Guide (Westport, CT, 1997).

Table 11. Design Capacities of Waste-to-Energy Facilities by Region, 1996 (Tons per Day)

\begin{tabular}{|c|c|c|c|c|}
\hline Region & Mean & Minimum & Maximum & Number of Facilities \\
\hline Northeast $\ldots \ldots \ldots \ldots \ldots \ldots$ & $1,021.2$ & 50 & 2,688 & 42 \\
\hline South ....... & $1,012.1$ & 40 & 3,150 & 34 \\
\hline North Central ... & 780.4 & 72 & 4,000 & 14 \\
\hline West $\ldots \ldots \ldots \ldots \ldots \ldots \ldots$ & 734.4 & 24 & 2,160 & 10 \\
\hline All Facilities $\ldots \ldots \ldots \ldots \ldots$ & 955.7 & 24 & 4,000 & 100 \\
\hline
\end{tabular}

Note: Two facilities did not list design capacities.

Source: Derived from Governmental Advisory Associates, Inc., Municipal Waste Combustion in the United States: 1996-97 Yearbook, Directory, and Guide (Westport, CT, 1997).

Table 12. Average Design Capacities of Waste-to-Energy Facilities by Type of Process and Region, 1996 (Tons per Day)

\begin{tabular}{|c|c|c|c|c|c|}
\hline \multirow[b]{2}{*}{ Type of Process } & \multicolumn{5}{|c|}{ Average Design Capacity } \\
\hline & Northeast & South & North Central & West & All Facilities \\
\hline Mass Burning, Modular . ......... & 255.6 & 149.7 & 88.7 & 100.0 & 154.9 \\
\hline Mass Burning, Waterwall & $1,185.1$ & $1,450.9$ & 559.3 & 778.0 & $1,179.6$ \\
\hline Mass Burning, Refractory & 240.0 & $1,000.0$ & - & 420.0 & 553.3 \\
\hline Mass Burning, Rotary Combustor . & $1,051.2$ & 355.0 & - & - & 852.3 \\
\hline All RDF Processes .... & $1,030.0$ & $1,825.0$ & $1,931.3$ & $1,455.0$ & $1,873.8$ \\
\hline
\end{tabular}

RDF $=$ refuse-derived fuel.

Note: One facility did not list a process type. Two facilities that listed process as mass burning codisposal with sludge were not included in the totals. Three facilities did not list design capacity.

Source: Derived from Governmental Advisory Associates, Inc., Municipal Waste Combustion in the United States: 1996-97 Yearbook, Directory, and Guide (Westport, CT, 1997). 


\section{Air Pollution Control Equipment}

Various types and designs of air pollution control equipment are used by most WTE facilities (Table 13). Dry scrubbers and baghouse filters used in combination are more efficient than most electrostatic precipitators in removing acid gases and particulates from stack gases. Nitrogen oxide and mercury emissions must also be controlled in most regions of the United States. Modular facilities that have exclusively used after-burn or two-chamber combustion systems can no longer rely on those systems for adequate pollution prevention in many parts of the United States. As a result, some have been retrofitted. Others have permanently closed down.

\section{Owners and Operators}

Almost half (48) of the WTE facilities in the United States are privately owned (Figure 12); 3 are joint public/private ventures; and the remainder are publicly owned. Twenty-five of the facilities owned by the public sector are operated by the private sector (Figure 13). Thus, 70 percent of all U.S. WTE facilities are operated by the private sector (Figure 14).

\section{The Landfill Gas Industry}

Municipal solid waste contains significant portions of organic materials that produce a variety of gaseous products when dumped, compacted, and covered in landfills. Anaerobic bacteria thrive on the oxygen-free environment, resulting in the degradation of the organic materials and the production of primarily carbon dioxide and methane. Carbon dioxide is likely to leach
Figure 12. Waste-to-Energy Facilities by Type of Ownership, 1996

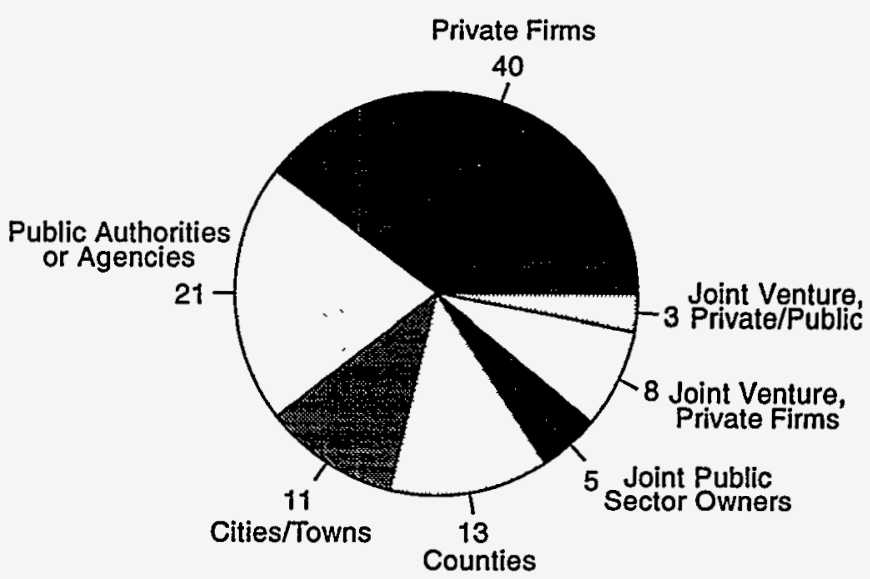

Note: One reporting facility did not list type of ownership. Source: Derived from Governmental Advisory Associates, Inc., Municipal Waste Combustion in the United States: 199697 Yearbook, Directory, and Guide (Westport, CT, 1997).

out of the landfill because it is soluble in water. Methane, on the other hand, which is less soluble in water and lighter than air, is likely to migrate out of the landfill. In the United States, there are 133 facilities that convert landfill gas (LFG) into energy at landfill sites that are either operational or temporarily shut down. ${ }^{57}$

\section{Location and Startup Date}

The LFG-to-energy facilities appear to be evenly distributed throughout the regions of the country. The West region has the largest number, followed by the

Table 13. Air Pollution Control Equipment at Waste-to-Energy Facilities by Type of Process, 1996 (Percent)

\begin{tabular}{|c|c|c|c|}
\hline \multirow[b]{2}{*}{ Type of Equipment } & \multicolumn{3}{|c|}{ Process Type } \\
\hline & Mass Burning & Modular Units & All RDF Processes \\
\hline Dry Scrubbers $\ldots \ldots \ldots \ldots \ldots \ldots$ & 68.7 & 22.7 & 80.0 \\
\hline Baghouse/Fabric Filters $\ldots \ldots \ldots \ldots \ldots$ & 53.1 & 22.7 & 60.0 \\
\hline Electrostatic Precipitators . . . . . . . . . & 39.1 & 63.6 & 46.7 \\
\hline Wet Scrubbers $\ldots \ldots \ldots \ldots \ldots \ldots$ & 1.6 & 13.6 & 6.7 \\
\hline Ammonia DeNox System . . . . . . . . . . & 21.9 & 4.5 & 20.0 \\
\hline Dry Sorbant Injection . . . . . . . . . . . & 25.0 & 0.0 & 6.7 \\
\hline After-Burn System . . . . . . . . . . & 0.0 & 22.7 & 0.0 \\
\hline Mercury Control System ........... & 0.0 & 0.0 & 0.0 \\
\hline Other Technologies $\ldots \ldots \ldots \ldots \ldots \ldots$ & 3.1 & 13.6 & 20.0 \\
\hline
\end{tabular}

$\mathrm{RDF}=$ refuse-derived fuel.

Note: One facility did not list process type.

Source: Derived from Governmental Advisory Associates, Inc., Municipal Waste Combustion in the United States: 1996-97 Yearbook, Directory, and Guide (Westport, CT, 1997).

${ }^{57}$ E.B. Berenyi and R.N. Gould, Methane Recovery from Landfill Yearbook (New York, NY: Governmental Advisory Associates, 1995). 
Northeast, North Central, and South (Figure 15). Almost one-third of all the facilities are located in California, and New York has the second largest number. These two States plus Pennsylvania, Michigan, Wisconsin, and Illinois have approximately two-thirds of all the facilities.

Figure 13. Waste-to-Energy Facilities by Relationship of Owner to Operator, 1996

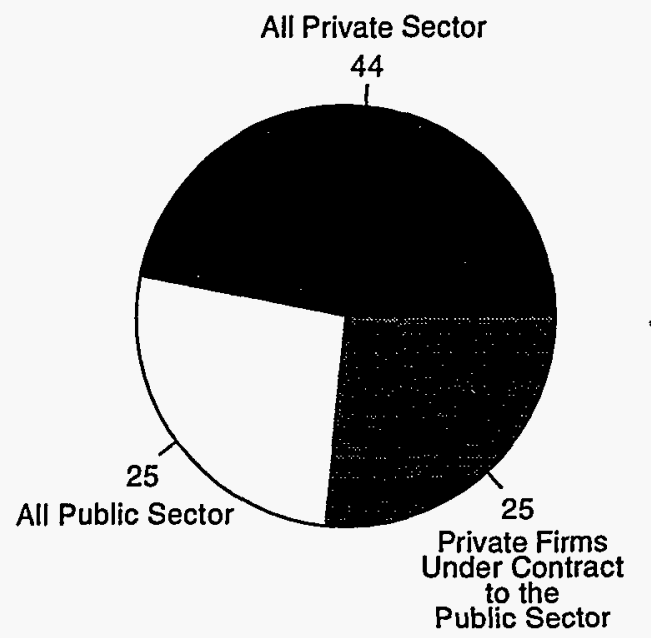

Notes: Seven reporting facilities did not list relationship between owner and operator. One reporting utility did not list type of ownership.

Source: Derived from Governmental Advisory Associates, Inc., Municipal Waste Combustion in the United States: 199697 Yearbook, Directory, and Guide (Westport, CT, 1997).

Figure 14. Waste-to-Energy Facilities by Type of Operator, 1996

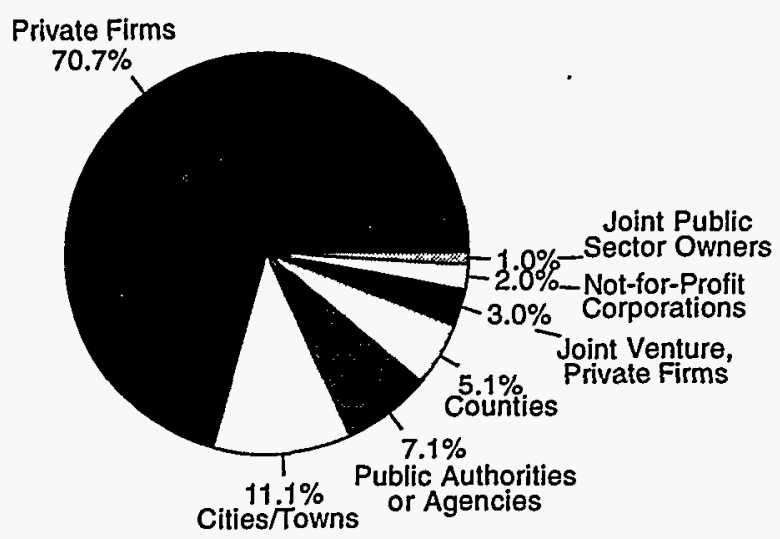

Note: Three reporting facilities did not list type of operator. Source: Derived from Governmental Advisory Associates, Inc., Municipal Waste Combustion in the United States: 199697 Yearbook, Directory, and Guide (Westport, CT, 1997).
The first LFG-to-energy facility began operation in 1979 after the enactment of PURPA. Approximately 70 percent of the 133 facilities that are in existence today began operation during the 7-year period 1984 to 1990 (Figure 16).

Figure 15. Location of Existing Landfill Facilities by Region, 1994

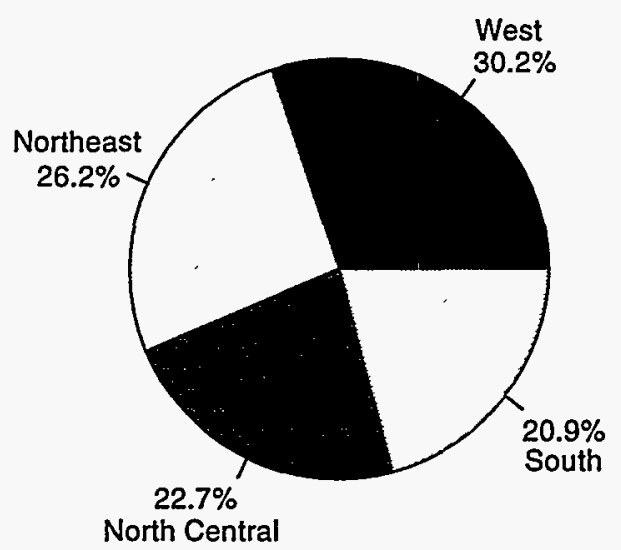

Source: Derived from Governmental Advisory Associates, Inc., Methane Recovery from Landfill Yearbook: 1994-95 (New York, NY, 1994).

Figure 16. Number of Landfill Gas Processing Facilities Entering Service by Year, 1979-1994

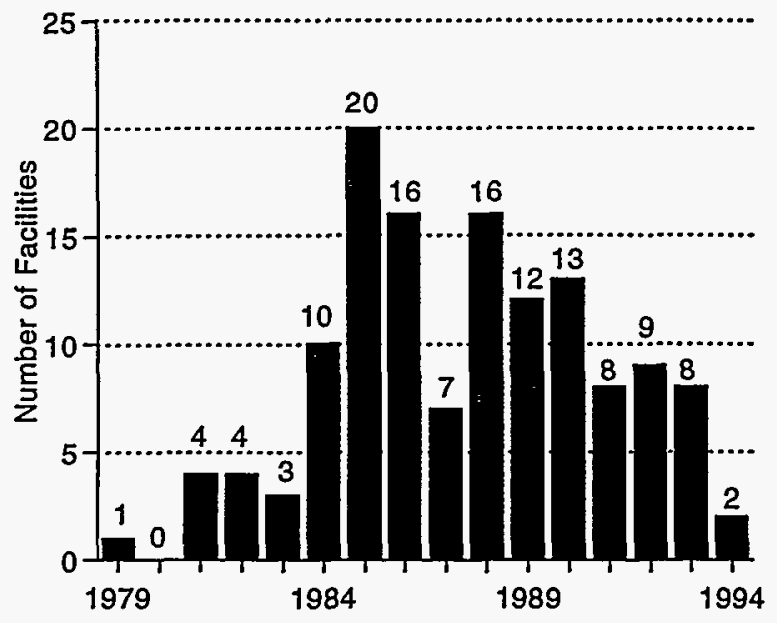

Source: Derived from Governmental Advisory Associates, Inc., Methane Recovery from Landfill Yearbook: 1994-95(New York, NY, 1994). 


\section{Energy Characteristics}

To collect LFG, wells are usually drilled 30 to 100 feet into a landfill. Key characteristics of a landfill that determine the amount of gas available include the type and compactness of the refuse buried, the length of time it has been buried, and the amount of rainfall in the area.

Historically, LFG has been collected and flared at sites because it was uneconomical to convert to energy. Energy applications include the use of low- to mediumBtu gas to generate electricity or as a boiler fuel. The LFG can also be upgraded for use in natural gas pipelines, and small amounts of LFG are used for soil remediation or synthetic fuels (Figure 17).

Most LFG-to-energy facilities create medium-Btu gas by filtering out particulate matter and removing water vapor. This gas has an energy value of approximately 500 Btu per cubic foot. Pipeline-quality gas (100 percent methane) can be created by further refinement to remove most of the carbon dioxide and other contaminants. However, in recent years the percentage of facilities producing pipeline-quality gas has declined as a result of low natural gas prices.

Approximately 75 percent of the LFG-to-energy facilities in the United States produce electricity (Figure 17). Prices for the sale of electricity from LFG plants in 1994 were reported for 82 facilities (existing and planned).
The average prices (in cents per kilowatthour) were $6.81,5.76,4.98$, and 4.39 in the West, Northeast, South, and North Central regions, respectively. Many of the facilities receive peak and off-peak rates. The rates presented above are average payments per kilowatthour, which may vary from year to year.

\section{Figure 17. Landfill Gas Utilization by Existing} Facilities, 1994

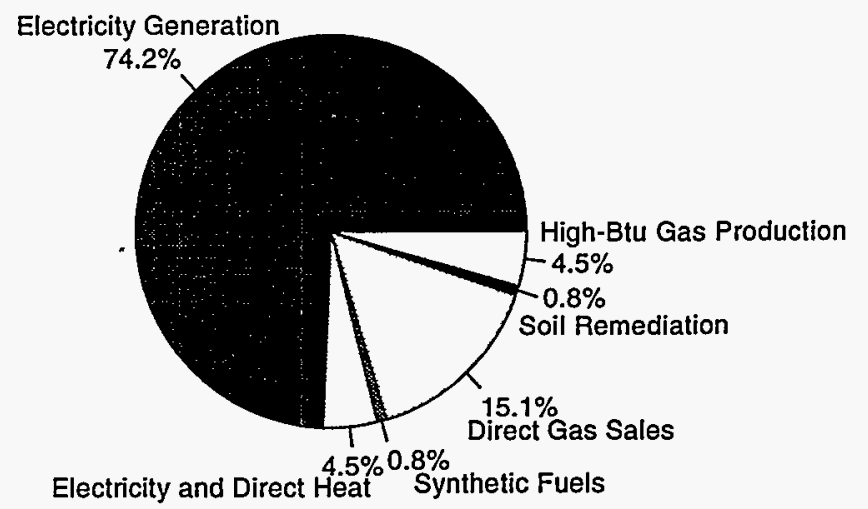

Note: One plant generates electricity, sells gas directly, and produces both pipeline-quality gas and synthetic fuels.

Source: Derived from Governmental Advisory Associates, Inc., Methane Recovery from Landfill Yearbook: 1994-95 (New York, NY, 1994). 


\section{Geothermal Energy Profile}

The basics of geothermal energy resources, electricity generation technology, and the state of the geothermal industry were reported by the Energy Information Administration in $1991 .^{58}$ In 1995, the first issue of the Renewable Energy Annual ${ }^{59}$ updated the status of various aspects of electricity generation from geothermal energy and reported preliminary data on direct consumption of geothermal energy. ${ }^{60}$ Since 1991, six new geothermal power plants have been brought into operation in the United States. In Nevada, Soda Lake II, a 13-megawatt binary plant began operating in 1991; Steamboat 2 and 3, two 14-megawatt binary plants began operating in 1992; and Brady Hot Springs, a 21 megawatt double-flash plant also entered service in 1992. In California's Imperial Valley, the 33-megawatt Heber station began operating in 1993. And in Hawaii, Puna, a 25-megawatt hybrid single-flash plant, began producing electricity in $1993 .^{61}$

In 1995, U.S. geothermal capacity totaled 2,968 megawatts nationwide (see Table 5 on page 13 of Chapter 1). This capacity produced $14,656,463$ thousand kilowatthours of electricity (see Table 4 on page 12). This amount of generation is roughly equivalent to 24 million barrels of oil, 7.5 million tons of coal (and 8.6 billion pounds of carbon in the form of carbon dioxide), or 152 billion cubic feet of natural gas (and 4.8 billion pounds of carbon). An important side benefit from geothermal power sources is the reduction in amount of hydrocarbons that need to be consumed and the associated greenhouse gases. ${ }^{62}$

\section{Activities in 1996}

With the construction of new geothermal power facilities stalled, the most significant event in 1996 for the U.S. geothermal industry was the startup of a new 40megawatt power plant in the Salton Sea known geothermal resource area (KGRA). Total geothermal electricity generation has continued to decrease, most notably as generation at The Geysers has declined. Most facilities, however, continue to produce steady quantities of electricity, including the Navy's Coso Hot Springs power plants (see Chapter 11 of this report, "Management of Known Geothermal Resource Areas").

Construction of new domestic electricity-producing geothermal facilities in the Western United States during 1996 was limited to one site, due to the availability of cheap, plentiful natural-gas-fired electricity in the West. With only one or two more geothermal sites continuing through the planning process, and with several other plans announced but showing little progress, the geothermal industry has searched abroad for new work.

Routine system maintenance and operation of virtually all geothermal facilities has led to a steady supply of electricity, with a high availability factor (often greater than 95 percent). Occasionally, the owners of a site consider an upgrade of steam supply system components, turbine, or generator. Currently, these decisions are made almost exclusively on economic grounds. Previously, such actions were often based on legislative or regulatory factors, which allowed avoided costs to be exceeded in utility contracts with independent power producers using renewable resources for fuel. Newer geothermal electricity contracts allow the purchasing utility to decline to buy a fixed number of hours of service without penalty, with take-or-pay options for the rest (see Appendix E, "Examples of Contract Arrangements at The Geysers"). The current market does not support the geothermal industry's efforts to maintain its share of the domestic electricity generation market.

Domestically, one unit was completed in 1996-Salton Sea Unit IV, a 40-megawatt project in the Imperial Valley. The area in the United States where a new geothermal power plant has the highest likelihood of being built (by the Calpine Corporation and TransPacific Geothermal Corporation) in the next few years

The author of this chapter is Jim Disbrow, Operations Research Analyst, Energy Information Administration.

${ }^{58}$ Energy Information Administration, Geothermal Energy in the Western United States and Hawaii, DOE/EIA-0544 (Washington, DC, September 1991).

${ }^{59}$ Energy Information Administration, Renewable Energy Annual 1995, DOE/EIA-0603(95) (Washington, DC, December 1995).

${ }^{60}$ Direct uses of geothermal energy have been summarized by the Geoheat Center at the Oregon Institute of Technology and are available on-line at web site www.oit.osshe.edu. See Appendix C of this report for a brief discussion of geothermal energy and geysers.

${ }^{61}$ Geothermal Resources Council, "NGA Power Database," web site www.geothermal.org (October 15, 1996).

${ }^{62}$ Environmental aspects of geothermal electricity generation are discussed in Appendix $\mathrm{D}$. 
is in the Glass Mountain KGRA in northern California, located about 50 miles south of Klamath Falls, Oregon. ${ }^{63}$ The Bonneville Power Administration (BPA) could purchase 20 megawatts from the 30-megawatt Glass Mountain power plant. Another candidate site was tested for sufficient resources in 1996. Preliminary well borings at the site, outside the Newberry National Volcanic Monument in Oregon's Deschutes National Forest, showed insufficient amounts of recoverable energy for power plant production.

With this modest level of activity, the U.S. geothermal energy industry has expanded its search abroad for new work and has been successful in signing contracts overseas, such as in the Philippines and Indonesia (see Chapter 12, "International Renewable Energy").

\section{Corporate Changes}

A major corporate merger occurred in 1994 when CalEnergy Company, Inc., acquired the Magma Power Corporation, including all of Magma Power's Salton Sea geothermal generating units. While the industry has been stable in recent years, the 15 years following deregulation of the electricity supply and distribution system should create an increased demand for the limited "green" electricity available from geothermal resources and for marketable renewable energy credits, if proposed legislation in Congress is enacted. ${ }^{64}$ Changing laws, regulations, and rate structures will also create both incentives and disincentives for geothermal heat pumps and direct uses of geothermal energy.

\section{Hot Dry Rock and Magma Resources}

Producing electricity from hot dry rock requires fracturing hot rocks, pumping water into and out of the hot rock, and generating electricity. Federal funding for research into energy recovery from hot dry rock has decreased to $\$ 1.7$ million in fiscal year 1997, and the Hot Dry Rock Program is being refocused to respond to industry needs. ${ }^{65}$ While demonstration of the approach has been successful, the technology remains uneconomical. Funding of energy extraction research has ended, primarily because equipment used to penetrate the magma is not certain to prevent a blowout, and a way to engineer the containment of such a highpressure, high-temperature blowout is unknown. Research continues in Japan and France, however.

\section{Direct Geothermal Energy}

Geothermal energy can be extracted directly for district heating and heat pumps (Table 14). District heating systems may deliver heat to the end user after passing the fluid through a central heat exchanger; thus, the geothermal fluid is not actually delivered to the end user. Such district heating systems exist in Boise, Idaho; San Bernardino, California; and Elko, Nevada; and a new one has been proposed in Reno, Nevada. District heating systems may also deliver the fluid itself to the end user. In both cases, the used geothermal fluid is either reinjected or disposed of on the surface.

Geothermal heat pumps (GHPs) always have heat exchangers. In a closed-loop GHP system, piping either in the ground or submerged in a pond contains a fluid that absorbs heat from its environment. An open-loop GHP system uses groundwater as a heat source and sink, transferring the groundwater to the heat pump unit.'

\section{District Heating Systems}

Many communities around the world have engineered ways to tap into geothermal hot water aquifers and significantly reduce their fossil fuel consumption. ${ }^{66}$ The Second Edition of the Geothermal Direct Use Engineering and Design Guidebook contains technical information on low- and moderate-temperature (100 to $\left.300^{\circ} \mathrm{F}\right)$ geothermal applications and equipment. The revised and updated version of the guidebook, prepared for the U.S. Department of Energy, represents a cooperative effort by the Oregon Institute of Technology, Idaho National Engineering Laboratory, University of Utah Research Institute, Battelle Pacific Northwest Laboratories, Radian Corporation, and the Washington State Energy Office.

\footnotetext{
${ }^{63}$ Personal communication with Dave Anderson, former Executive Director, Geothermal Resources Council (September 13, 1996).

${ }^{64}$ H.R. 3790, the "Electric Consumers' Power to Choose Act of 1996," would restructure the entire electricity generating, transmission, and distribution industry. It would also create a Federal market for renewable energy credits, which would be available from utilities contracting for electricity from geothermal facilities.

${ }^{65}$ U.S. Department of Energy, Office of Energy Efficiency and Renewable Energy, Geothermal Division, FY 1996 Program Summary.

${ }^{66}$ P.J. Lienau et al., Reference Book on Geothermal Direct Use (Oregon Institute of Technology, Geoheat Center, August 1994). Prepared for the U.S. Department of Energy, Geothermal Division.
} 
Table 14. Temperatures of Geothermal Fluids Required for Various Uses

(Degrees Centigrade)

\begin{tabular}{|c|c|c|}
\hline Temperature & State & Uses \\
\hline 180 & $\begin{array}{l}\text { Saturated Steam } \\
1\end{array}$ & $\begin{array}{l}\text { Conventional power production; evaporation of highly concentrated solutions; refrigeration } \\
\text { by ammonia absorption; digestion in paper pulp, kraft }\end{array}$ \\
\hline 170 & 1 & $\begin{array}{l}\text { Conventional power production; heavy water via hydrogen sulfide process; drying of } \\
\text { diatomaceous earth }\end{array}$ \\
\hline 160 & 1 & Conventional power production; drying of fish meal; drying of timber \\
\hline 150 & 1 & Conventional power production; alumina via Bayer's process \\
\hline 140 & 1 & Conventional power production; drying of farm products at high rates; canning of food \\
\hline 130 & 1 & $\begin{array}{l}\text { Conventional power production; evaporation in sugar refining; extraction of salts by } \\
\text { evaporation and crystallization }\end{array}$ \\
\hline 120 & 1 & $\begin{array}{l}\text { Fresh water by distillation; most multiple-effect evaporations; concentration of saline } \\
\text { solutions }\end{array}$ \\
\hline 110 & 1 & Drying and curing of light aggregate cement slabs \\
\hline 100 & 1 & Drying of organic materials (seaweeds, grass, vegetables, etc.) \\
\hline 90 & Water & Drying of stock fish; intense de-icing operations \\
\hline 80 & 1 & Space heating; greenhouse space heating \\
\hline 70 & 1 & Refrigeration (lower temperature limit) \\
\hline 60 & 1 & Animal husbandry; greenhouse combined space and hotbed heating \\
\hline 50 & 1 & Mushroom growing; balneological baths \\
\hline 40 & 1 & Soil warming \\
\hline 30 & 1 & $\begin{array}{l}\text { Swimming pools; biodegradation; fermentations; warm water for year-round mining in cold } \\
\text { climates; de-icing }\end{array}$ \\
\hline 20 & 1 & Hatching of fish; fish farming \\
\hline
\end{tabular}

Source: J.S. Rinehart, Geysers and Geothermal Energy (New York, NY: Springer-Verlag, 1980), p. 176.

Klamath Falls, Oregon, has had several decades of reliable use from its geothermal district heating system. Iceland has had centuries of warmth in homes and businesses through district heating systems. In neither case is there a need for air conditioning. The City of San Bernardino, California, uses geothermal energy directly in a district heating program. The City of San Bernardino is located near several earthquake fault zones, including the San Jacinto, Loma Linda, and San Andreas faults. The consequence of being close to these faults is that, since the turn of the century, residents of San Bernardino have, on a very small scale, enjoyed natural heat in the form of steam baths and hot springs. Many wells in the valley exhibit temperatures between 120 and $140^{\circ} \mathrm{F}$. The heating district lies in the southwest portion of the city and currently serves more than 35 public and private buildings. Similarly, geothermal water warms greenhouses in Idaho, nurtures fish runs in Utah, and provides hot baths at resorts in Virginia.

\section{Geothermal Heat Pumps}

No active technology for home cooling is more efficient than the geothermal heat pump. ${ }^{67}$ Ground-coupled heat pumps use moist earth-temperature soil ${ }^{68}$ for heating during the winter, cooling during the summer, and supplying hot water year-round. Water-to-air heat pumps exchange heat with either groundwater, surface water, or water passed through cooling towers (for industrial or commercial use). A ground-coupled heat pump system begins with the installation of either coils of plastic piping buried 6 to 10 feet in the earth, long runs of tubing in trenches, or similar piping under the freeze level of a pond or lake. The goal is reached with a greatly reduced electricity bill of $\$ 1$ per day for single-family dwellings; however, these systems may have a payback period in excess of 5 years. As electricity rates drop, this payback period will get longer and longer, unless equipment and installation costs drop dramatically.

\footnotetext{
${ }^{67}$ Energy Information Administration, Annual Energy Outlook 1994, DOE/EIA-0383(94) (Washington, DC, January 1994$)$, Table 21.

${ }^{68}$ Groundwater temperatures hover around $50^{\circ} \mathrm{F}$ most of the year in most parts of the lower 48 States. For space heating, geothermal heat pumps have the second best average equipment efficiency of the major equipment types.
} 
In a 1988 survey of GHP buyers, 97 percent said that they were happy with their purchase and would buy again. Approximate estimates of the total number of geothermal ground-coupled heat pumps installed and in use range between 100,000 and 350,000 residences in the United States, out of a total of about $100,000,000$ residences. ${ }^{69}$ GHPs can be effectively used over the range of earth and air temperatures found in the United States, if designed and implemented properly. Economies of scale favor the conversion of large buildings with circulating water systems for heating and cooling.

The heat pump itself operates on the same principal as the home refrigerator, which is actually a one-way heat pump. The GHP, however, can move heat in either direction. In the winter, heat is removed from the fluid and delivered into the home or building (heating mode). In the summer, heat is removed from the home or building and delivered into the earth for storage, diluting and dispersing it (air-conditioning mode). On either cycle, household water can be heated and stored, efficiently replacing or reducing the requirement for a separate hot water heater. Since electricity is used only to transfer heat, not to produce it, the GHP will extract three to four times more energy than it consumes.

Heat flows naturally from a warm area to a cooler area. In its heating mode, a heat pump's outside groundsource fluid passes across a coil (called the evaporator) containing some refrigerant, a liquid which boils at a very low temperature (as low as $15^{\circ} \mathrm{F}$.) When the refrigerant boils, it becomes a vapor, which is sucked into a compressor where it is pressurized. The vapor is then forced through a coil (called the condenser) within part of the heat pump located indoors. As cool indoor air passes over the coil, the vapor cools and turns back to a liquid, releasing heat that is blown through a duct system to heat the house.

The cycle begins again as the liquid refrigerant, cooled by releasing its heat into the house, is pumped back outside. On the way, it passes through an expansion valve, lowering the refrigerant's pressure and temperature again so that it can boil more easily in the coil. In its cooling mode, the heat pump works in reverse, extracting available heat from indoors and transferring it outside and into the ground.

The GHP unit sits inside the home or building, at the site of a normal gas furnace. In a typical closed loop installation, a loop of long plastic pipe (i.e., from one hundred to several hundred feet) is placed down a nearby hole-or horizontally 6 to 10 feet deep-and the hole is backfilled with clay. A water/antifreeze solution is circulated through the loop and through the heat pump to remove heat from or transferring it to the ground. No groundwater is used; no contact occurs between the solution in the plastic pipe and the earth. Installation easily conforms to local construction and well drilling regulations. Typical loop installations have 50-year warranties.

GHP installations are being actively promoted by a few investor-owned utilities and rural electrical cooperatives as a means of promoting energy efficiency and better managing demand. GHPs are estimated to cut 1 to 5 kilowatts of peak generating capacity requirement per residential installation. Since rural electric cooperatives often pay their electricity suppliers a rate based on the rate at the time peak load is experienced, shaving this peak reduces rates for all the members of the cooperatives.

\footnotetext{
${ }^{69}$ Energy Information Administration, Annual Energy Outlook 1994, DOE/ELA-0383(94) (Washington, DC, January 1994 ), Table 21.
} 


\section{Wind Energy Profile}

\section{Overview}

The worldwide capacity of installed wind power was 4,900 megawatts in $1995 .^{70}$ Outside the United States, significant wind capacity is installed or proposed for near-term installation in Germany, Denmark, India, the Netherlands, Spain, and China. Sales of wind technologies to Europe are becoming increasingly important, while the U.S. share of worldwide windpower capacity continues to decline. In 1993, 80 percent of the worldwide wind power industry sales were to Europe, and in 1994 Germany accounted for almost one-half of the new capacity installed worldwide. The U.S. share of the world's installed wind capacity fell from 92 percent in 1988 to less than 50 percent in $1994^{71}$ and 35 percent in $1995 .^{72}$ While new installed wind turbine capacity worldwide reached its single-year high in 1995, the U.S. share was less than 10 percent.

In the United States, the country with the most installed wind power, capacity was 1,731 megawatts at the end of 1995. ${ }^{73,74}$ Wind-powered electricity generation in the U.S. electric utility sector increased significantly in 1995 to 11,000 megawatthours. A significant project in the utility sector, the 6.8-megawatt Solano Wind Project of the Sacramento Municipal Utility District, began operation in 1994 and generated nearly 11,000 megawatthours in 1995. In addition, two plants began operating in Texas in 1995: a 6.6-megawatt facility (12 Zond turbines) operated by West Texas Utilities, and a 35megawatt facility operated by Kenetech Windpower (see footnote 74).

Although most of the on-line wind energy projects in the United States are located in California, recent installations have broadened the geographical distribution of wind power capacity. With the help of legislation encouraging the utilization of alternative energy sources, wind power plants are already finding homes in States such as Texas and Minnesota (with 42 megawatts and 26 megawatts of installed capacity, respectively)..$^{75}$ Additionally, Minnesota has mandated that Northern States Power Company acquire 425 megawatts of wind generation capacity by 2002, and Iowa now requires investor-owned utilities to spend 2 percent of their funds for power from alternative energy sources ${ }^{76}$ (see box on page 42 ).

The breakdown of U.S. wind capacity as of September 1996, by State, is shown in Table 15. California has 95 percent of the operational wind capacity in the country, while Minnesota has 61 percent of the planned capacity. Of the total 659 megawatts of planned capacity, 15 megawatts is under construction, 140 megawatts is

\section{Table 15. U.S. Wind Electricity Generation Nameplate Capacity by State as of September 1996 (Megawatts)}

\begin{tabular}{|c|c|c|}
\hline State & Online & Planned \\
\hline California . . . . . . . & 1,635 & 9 \\
\hline Texas . . . . . . . . . & 42 & 40 \\
\hline Minnesota $\ldots \ldots \ldots$ & 26 & 400 \\
\hline Hawaii .......... & 12 & 0 \\
\hline lowa ........... & 2 & 32 \\
\hline Michigan $\ldots \ldots \ldots$. & 1 & 0 \\
\hline Wyoming . . . . . . & 0 & 68 \\
\hline Washington $\ldots \ldots \ldots$ & 0 & 56 \\
\hline Oregon ........... & 0 & 25 \\
\hline Maine . . . . . . . . & 0 & 10 \\
\hline Wisconsin . . . . . . . & 0 & 10 \\
\hline Vermont .......... & 0 & 6 \\
\hline Massachusetts ...... & 0 & 3 \\
\hline U.S. Total $\ldots \ldots$. . & 1,718 & 659 \\
\hline
\end{tabular}

Note: Planned capacity includes additions through 2003 and consists of 15 megawatts under construction, 140 megawatts under contract, 68 megawatts under agreement, 289 megawatts mandated but not yet under contract, and 147 megawatts proposed.

Source: U.S. Department of Energy, Office of Energy Efficiency and Renewable Energy, "Wind Energy Data: Monthly Summary Report" (September 1996).

${ }^{70}$ International Energy Agency, Wind Energy Annual Report 1995 (Paris, France, March 1996), p. 20.

${ }^{71}$ S. Williams and B.G. Bateman, Power Plays (Washington, DC: Investor Responsibility Research Center, 1995), p. 255.

${ }^{72}$ International Energy Agency, Wind Energy Annual Report 1995, p. 20; and Energy Information Administration, Electric Power Annual 1995, Vol. 2, DOE/EIA-0348(95/2) (Washington, DC, December 1996), pp. 15-16.

${ }^{73}$ Energy Information Administration, Electric Power Annual 1995, Vol. 2, pp. 15-16.

${ }^{74}$ Excludes 6.6 megawatts of utility capacity and 35 megawatts of nonutility capacity that were not captured by EIA sources.

${ }^{75}$ U.S. Department of Energy, Office of Energy Efficiency, "Wind Energy Data: Monthly Summary Report" (September 1996$)$, p. 7.

${ }^{76}$ U.S. Department of Energy, Wind Energy Program Overoiew: Fiscal Year 1994, DOE/G0-10095-071 (Washington, DC, 1995$)$, p. 1. 


\section{Northern States Power Co.}

In the early 1990s, Northern States Power Co. (NSP) negotiated an agreement with the State of Minnesota requiring the utility to install 425 megawatts of wind capacity and 125 megawatts of biomass capacity by the end of 2002, in return for permission to expand on-site storage of spent nuclear fuel at its nuclear power plants.* Currently, NSP buys power from a 25-megawatt wind facility consisting of 73 Kenetech turbines. The facility operates at a 33 percent capacity factor with no mechanical difficulties.** This capacity factor is largely dependent on resource availability (wind is an intermittent resource) and not on mechanical reliability. The utility is planning to expand the Buffalo Ridge project by 100 megawatts with 143 700-kilowatt Zond Systems, Inc. wind turbines. Zond was the successful bidder at a levelized cost of energy close to 3 cents per kilowatthour. Extending transmission lines to the Buffalo Ridge project is estimated to cost about $\$ 100$ per kilowatt. Many landowners in the area have sold NSP perpetual rights to the wind energy on their land. The company expects to spend $\$ 5.15$ million for the rights to the energy associated with the 100-megawatt facility. The Buffalo Ridge area has average wind speeds of about $16.1 \mathrm{mph}$.**

*L. Lamarre, "Renewables in a Competitive World," EPRI Journal, Vol. 20, No. 6 (November/December 1995), web site www.epri.com.

**'Wind Energy Firm Flounders," Engineering News Record, December 25, 1995, p. 16.

***Northern States Power, "Proposed 100 MW Wind Energy Generating Facility," Docket No. E-002/CN-94-795 (September 23, 1994).

under contract, 68 megawatts agreed upon, 289 megawatts mandated, and 147 megawatts proposed.

\section{The Role of Government}

Funding for wind programs by the U.S. Government began in the 1970s, peaking at $\$ 60$ million in 1980 . During the 1980s those resources declined, bottoming out at less than $\$ 10$ million per year from 1988 through 1990. The 1990s have again seen a reversal, with a funding level of $\$ 45$ million in 1995.7 The program budget has declined again, however, in fiscal years 1996 (\$31.5 million) and 1997 (\$29 million).
The Energy Policy Act of 1992 (EPACT) established the following tax incentives for wind energy: a 10-year production tax credit of 1.5 cents per kilowatthour for projects brought on line between 1994 and 1999, and a production incentive payment of 1.5 cents per kilowatthour for publicly owned (non-taxpaying) entities unable to use the tax credits. ${ }^{78}$ These positive factors have been tempered by the uncertainty of the continuation of the credits and payments. At present, utilityscale wind energy projects produce electricity at a cost of 5 to 7 cents per kilowatthour. ${ }^{79}$

The Federal Government provides technical assistance in the development of wind energy through the U.S. Department of Energy (DOE) Wind Energy Program, the National Renewable Energy Laboratory's (NREL) National Wind Technology Center (NWTC), and Sandia National Laboratories (SNL). NREL is the primary player in the Advanced Wind Turbine Program, the Value Engineered Turbine Program, and the wind characterization program that originated at Pacific Northwest Laboratories.

DOE's Wind Energy Program, in conjunction with industry, supports the development and testing of wind turbine technology at both the individual component and full system levels. The purpose of this activity is to decrease costs through increased operating efficiency from improvements in variable speed characteristics, large rotor design, and weight reduction. Machines of proven configuration developed under this program and nearing completion include: ${ }^{80}$

- Atlantic Orient Corporation-AOC 15/50 (50 kilowatts capacity)

- FloWind Corporation-AWT-27 (275 kilowatts), EHD (300 kilowatts)

- New World Power Corporation-North Wind 250 (250 kilowatts)

- Zond Energy Systems-Z-40 (500 kilowatts).

The next generation of turbines, now under development, includes:

- Wind Turbine Company-WTC-1000 (1,000 kilowatts)

- Zond Energy Systems-Z-56 (1,078 kilowatts)

- Cannon Wind Eagle.

The program also supports development of innovative subsystems, such as power conditioning and controls,

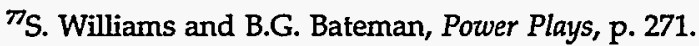

${ }^{78}$ S. Williams and B.G. Bateman, Pozver Plays, p. 266.

${ }^{79}$ D.F. Ancona, P.R. Goldman, and R.W. Thresher, "Wind Program Technological Developments in the United States," paper presented to the World Renewable Energy Congress (Denver, CO, June 18, 1996), p. 1.

${ }^{80}$ D.F. Ancona, P.R. Goldman, and R.W. Thresher, "Wind Program Technological Developments in the United States," p. 5. 
trailing edge aerodynamic brakes, and multi-blade flexible rotors. ${ }^{81}$ A blade manufacturing project by SNL supports attempts to improve the cost, quality, and reliability of wind turbine blades. World market sales of turbines developed under this program have exceeded $\$ 300$ million. $^{82}$

In 1994, the NWTC was designated and dedicated near Golden, Colorado. It features laboratories, computer facilities, and testing facilities to assist in the design, testing, and evaluation of new turbines. Sixteen turbine test pads are available to test systems up to 1 megawatt in capacity, and a turbine with special instrumentation is in place for studies of aerodynamic and structural responses to turbulence. NWTC's location is ideal for testing turbines under a variety of conditions. In the fall and winter, strong, turbulent winds from the west mimic winds in California; in the spring, stable (laminar) easterly winds mimic the U.S. Great Plains and much of Europe. ${ }^{83}$ These conditions allow testing under both extreme conditions and those typical of the Great Plains, where nearly 50 percent of U.S. wind resources are located.

NWTC also houses NREL's Wind Technology Division, which operates five 80-meter (262-foot) meteorological towers on the eastern and western boundaries of the site. The towers are used to develop and test instruments and procedures for evaluating wind characteristics, including seasonal patterns and turbulence of the local wind resource. Currently, three commercial turbines are installed at the site: Atlantic Orient Corporation's AOC 15/50, Advanced Wind Turbines' AWT-26 (both developed under DOE's Wind Turbine Development Program), and a 10-kilowatt turbine developed by Bergey Windpower Company. ${ }^{84}$ Installation of a fourth commercial turbine (Wind Eagle) is underway. In addition, there are two installed research turbines (15 kilowatts).

An Industrial User Facility is operational at NWTC. It is designed to encourage collaboration between Government and industry in technology innovation, through cooperative research and development agreements. To that end, the testing facilities are partitioned into three separate, secure areas to protect the intellectual property of the participating commercial firms. Capabilities are also being developed to support certification testing, which is emerging as a requirement for the export of wind energy systems to many overseas markets.

The National Wind Coordinating Committee (NWCC) was formed in 1994 as a result of efforts by the American Wind Energy Association (AWEA), Electric Power Research Institute (EPRI), ${ }^{85}$ Edison Electric Institute (EEI), American Public Power Association (APPA), and DOE. ${ }^{86}$ Its members include utilities, environmental groups, utility consumer advocates, utility regulators, other State and Federal government officials, and the wind industry. The purpose of the committee is to plot an orderly path for the development of wind power into a self-sustaining commercial market. Its mission is to identify key issues, facilitate dialogue between the affected parties, and formulate appropriate responses. Immediate issues of concern are regulatory and environmental barriers to renewable energy, transmission access and pricing, and accurate wind resource assessment.

The Utility Wind Resource Assessment Program provides assistance to utilities in evaluating the wind resources in their service areas. Monitoring of wind speeds at proposed turbine heights is conducted for at least 1 year to verify that economical wind resources exist at the proposed site. The program, initiated by the NWCC with the support of DOE, is managed by the Utility Wind Interest Group. ${ }^{87}$

The Utility Wind Interest Group, a consortium of 16 utilities and industry organizations, was formed in 1989 with the support of DOE and EPRI to exchange experience and information on wind power. It currently includes the following members: ${ }^{88}$

- Alaska Village Electric Cooperative, Inc.

- Central and Southwest Services

- Conservation and Renewable Energy Systems (CARES)

- Green Mountain Power Corporation

- Edison Electric Institute

- Kansas City Power \& Light Company

\footnotetext{
${ }^{81}$ A trailing edge aerodynamic brake is a movable flap, known as a "spoiler flap," mounted on the downwind edge of a wind turbine blade, which rotates up or down to control turbine rotor speed. Vortex generators are small protrusions on wind turbine blades that help to keep airflow attached to the blades. Multi-blade flexible rotors are rotors with three or more turbine blades constructed of a lightweight, highly flexible material.

${ }^{82}$ D.F. Ancona, P.R. Goldman, and R.W. Thresher, "Wind Program Technological Developments in the United States," p. 4.

${ }^{83}$ U.S. Department of Energy, Wind Energy Program Overview: Fiscal Year 1994, p. 6.

${ }^{84}$ U.S. Department of Energy, Wind Energy Program Overview: Fiscal Year 1994, p. 7.

${ }^{85}$ EPRI's wind budget doubled from $\$ 1.1$ million in 1994 to $\$ 2.2$ million in 1995 .

${ }^{86}$ S. Williams and B.G. Bateman, Power Plays, p. 267.

${ }^{87}$ U.S. Department of Energy, Wind Energy Program Overview: Fiscal Year 1994, p. 10.

${ }^{88}$ S. Williams and B.G. Bateman, Power Plays p. 269.
} 
- Electric Power Research Institute

- Kotzebue (Alaska) Electric Association

- Niagara Mohawk Power Corp.

- Northeast Utilities Service Company

- Northern States Power Company

- Public Service Company of Colorado

- Sacramento Municipal Utility District

- Southwestern Public Service Company

- TU Electric

- Waverly Light \& Power

- Wisconsin Electric Power Company.

The Utility Wind Turbine Performance Verification Program was started in 1992 by DOE and EPRI to accelerate the commercialization of wind power. Its goal is to reduce the risk of testing and evaluating advanced wind energy technology for utility use. Participating utilities will be subsidized to build and operate wind power plants of at least 6 megawatts capacity, using the latest technology. ${ }^{89}$ Each utility will select a site, solicit bids from U.S. vendors, and purchase the turbines. The utilities will also be responsible for power plant design, construction, startup, and 3 years of testing, evaluation, and documentation. The experience is intended to allow utilities to make more informed decisions about the latest turbines. In 1993, Green Mountain Power Corporation was awarded $\$ 2$ million for 11 Zond Z-40 turbines, each rated at 550 kilowatts. Central and Southwest Services, Inc. was awarded $\$ 2$ million for 12 Zond Z-40 turbines, each rated at 550 kilowatts. These turbines became operational in September 1995.

Executive Order 12902 (March 1994) requires the U.S. Department of Defense (DOD) to increase its use of renewable energy. DOD is the Government's largest consumer of energy. Potentially, thousands of diesel generators could be replaced by wind turbines at U.S. military installations with good wind resources. NREL is now working with the U.S. Navy to design and build a wind generation system of up to 1-megawatt on San Clemente Island. Also, NREL has collected wind data for assessment of a potential project on San Nicholas Island off the California coast between San Diego and Los Angeles. The Wind Turbine Development Program is working with industry to develop small (20 to 40 kilowatts) advanced turbines.

\section{The Commercial Industry}

The major wind energy equipment manufacturers in the United States are Atlantic Orient Corporation, Bergey
Windpower Company, Cannon Power Corporation, FloWind Corporation, Kenetech Windpower, Wind Eagle Corporation, Wind Turbine Company, and Zond Systems, Inc. Kenetech Windpower, FloWind, Zond, and Cannon are vertically integrated-in addition to designing complete wind turbine systems, the companies also provide leadership in wind farm project development and work in partnership with research consortia and Government agencies to design, test, and develop new wind turbine components. Kenetech Windpower (a subsidiary of the Kenetech Corporation) is the only large-volume manufacturer among the companies and one of the few dedicated wind energy system manufacturers that is publicly owned; however, Windpower is currently under Chapter 11 corporate reorganization.

New World and SeaWest do not manufacture wind turbines, but instead develop and operate wind power plants. Both companies consider their independence from a particular piece of technology as an advantage, allowing them flexibility to choose the turbine design most appropriate for a given project. In the early years of the wind industry, large companies, such as Boeing, General Electric, Westinghouse, Bendix, and Alcoa, were involved in the government-sponsored development of multi-megawatt turbines. When those machines proved to be uneconomical under the conditions of the 1980s, the companies dropped out. More recently, however, improvements in cost efficiency have started to draw large companies back into the business, including Westinghouse, Dow Chemical, United Technologies, Teledyne, and Bechtel. Atlantic Orient Corporation is also a U.S. turbine manufacturer, but it is not involved in power plant construction or electricity generation.

The following are the larger operators of U.S. wind energy power plants: ${ }^{90}$

- Cannon Power: 703 units, 82.2 megawatts capacity in 1994

- FloWind: 864 units, 139.9 megawatts capacity, $\$ 9.44$ million in revenue in 1993

- Kenetech Windpower: 4,334 units, 494.7 megawatts capacity in 1994, \$236 million in revenue in 1993

- New World Power: 450 units, 44.4 megawatts capacity, \$7.66 million in revenue in 1993

- SeaWest Energy: 2,641 units, 327.7 megawatts capacity in 1993

- Zond Systems: 2,459 units, 258.9 megawatts capacity in 1994.

${ }^{89}$ U.S. Department of Energy, Wind Energy Program Overview: Fiscal Year 1994, pp. 9-10.

${ }^{90}$ S. Williams and B.G. Bateman, Power Plays Pp. 277-309. 
Much of the installed wind capacity in the United States was manufactured overseas. Major foreign wind energy companies are Vestas/DWT, Nordtank, Bonus, Micon, and Wind World of Denmark; Nedwind and Windmaster of the Netherlands; Enercon and Tacke of Germany; Wind Energy Group of the United Kingdom; and Mitsubishi of Japan.

Many wind energy system manufacturers are also power generators. This circumstance is characteristic of the early days of the industry, when risk factors dissuaded larger, well-established corporations from participating in wind energy projects. As utilities increase their direct role in the wind industry, however, this situation should change.

In 1994, the Sacramento Municipal Utility District became the first utility to own a large-scale wind project in the United States. Other utilities with outright or joint ownership of wind farms include Lower Colorado River Authority, Central and South West Corporation, and Hawaiian Electric Industries. Northem States Power, Minnesota's largest utility, has been mandated by the State Senate to install 425 megawatts of wind capacity over the next 7 years (see box on page 42). In addition, a consortium of Washington State utilities, known as CARES (the Conservation and Renewable Energy System), intends to install 25 megawatts in 1997.91

\section{Technology and Ownership Issues}

Wind turbine technology began with small turbines, with generating capacities of 50 kilowatts or less. As the technology has matured, the focus of production, research, and development has shifted to significantly larger turbines. Today, 70 percent of the world's wind turbines are in the 50- to 150-kilowatt range. ${ }^{92}$ Several international manufacturers have produced turbines with capacities greater than 1 megawatt; however, research has shown that economies of scale (increased efficiency of power production with greater capacity) associated with larger turbines do not increase in proportion to their cost. Therefore, it is likely that the next generation of wind farms will be powered by turbines with capacities of 300 kilowatts to 1 megawatt (1,000 kilowatts).

Since no combustion occurs in wind projects, there are no emissions. Every megawatthour (thousand kilowatthours) of electricity generated by a wind turbine offsets the equivalent of 0.5 to 1 kilogram of carbon dioxide, up to 7 kilograms of sulfur and nitrogen oxides and particulates, 0.1 kilogram of trace metals (e.g., mercury), and more than 0.2 kilograms of solid waste from fossilfueled generation. ${ }^{93}$

Most wind energy projects are financed by the manufacturer, institutional investors, or investment brokers. Potential investors require a rate of return higher than average because of the perceived risk and uncertainty of wind projects in the United States, which restricts the cost competitiveness of wind energy projects relative to other types of power. Continuing increases in cost efficiency and technological capability, however, are beginning to attract greater attention from utilities. The utilities will likely shift the structure of wind energy development and ownership away from independent, or nonutility, power producers, which dominated the early years of the industry by their willingness to assume greater financial risk.

\section{Changes in Technology, Industry Structure, and Project Management}

The modern wind industry began in 1981, following the enactment of the Public Utility Regulatory Policies Act of 1978 (PURPA). More than 1,000 megawatts of capacity was installed by 1985, far exceeding the goal of 800 megawatts by 1988, as set forth in the 1980 Wind Energy Systems Act. ${ }^{94}$ Incentives during the 1980-1985 period included a 15-percent renewable energy tax credit, a 10-percent investment tax credit, and accelerated 5-year depreciation. In California, incentives included State tax credits, an attractive utility buyback rate, and a favorable political climate.

The tax credits of the early 1980s, government funding, and support for research and development were critical in overcoming the technological design and manufacturing problems of early wind turbines. However, the value of the tax credits was based on the installed cost of a project, which caused problems, as some turbines were installed with only minimal testing in order to qualify before the tax credits expired. ${ }^{95}$ Today's credits are based on performance criteria, not merely on the amount of capital invested. One emphasis in applied wind technology is on replacing existing capacity with the latest turbine designs, which are less costly to maintain and more efficient to operate. ${ }^{96}$ In California, this will occur as the interim Standard Offer No. 4 contracts,

${ }^{91}$ U.S. Department of Energy, Wind Energy Program Overview: Fiscal Year 1994, p. 1.

${ }^{92}$ J. Loyola, Wind Performance Reporting System: 1991 Annual Report (Sacramento, CA: California Energy Commission, December 1992).

${ }^{93}$ Paul Gipe \& Associates, 1996 Overview of Wind Generation Worldwide (Tehachapi, CA, July 31, 1996$)$, p. 4.

${ }^{94}$ S. Williams and B.G. Bateman, Power Plays, p. 255.

${ }^{95}$ S. Williams and B.G. Bateman, Power Plays, p. 257.

${ }^{96}$ S. Williams and B.G. Bateman, Power Plays, p. 258. 


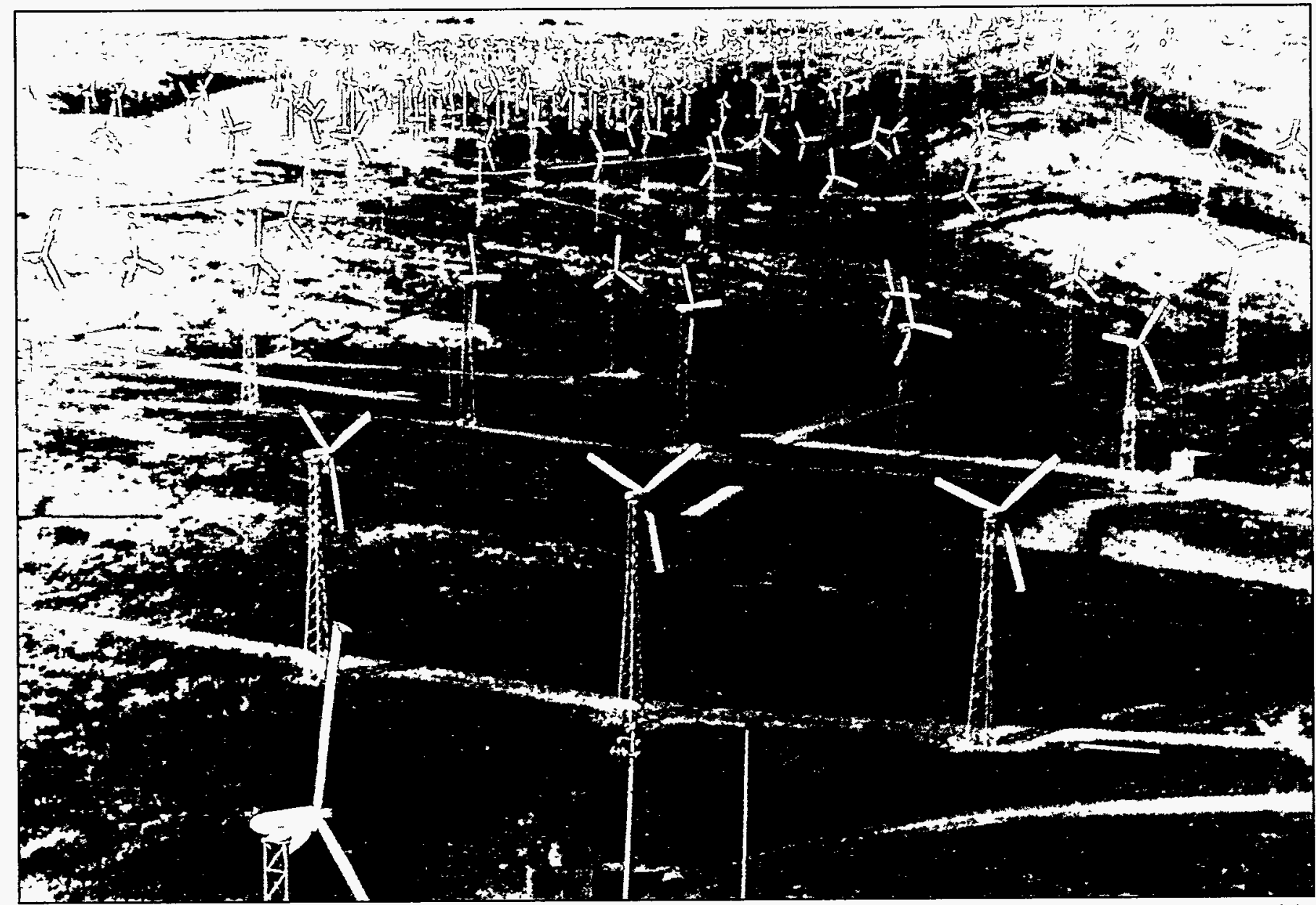

Horizontal-axis wind turbines, developed by Enertech Corp. and the U.S. Department of Energy, located in Altamont Pass, CA.

which specify a generous fixed price for power generated, expire (about 140 megawatts had expired by 1994 , another 540 megawatts in 1995, and 200 megawatts in 1996).

During the period 1980-1985, almost all wind energy development was third-party financed-that is, taxadvantaged limited partnerships of individual investors or even individual purchases of wind turbines as personal property. ${ }^{97}$ Although new installation of wind systems dropped after 1985 (except for a brief resurgence during 1990-1991), generation has increased in every year.

Before 1993, all the utility-scale wind power plants in the United States were installed in California, with the exception of approximately 20 megawatts in Hawaii. In
1994, Minnesota joined this group, and there are now projects under development in 10 other States. ${ }^{98}$ Through the early 1990s, virtually all wind energy plants were owned by independent power producers (IPPs). Today, the drop in prices and financial risk, the rise in technical efficiency and reliability, and legislative mandates have increased the involvement of major utilities in wind power development and investment. ${ }^{99}$

The average cost of electricity from wind energy has dropped from 50 cents per kilowatthour in 1980 to approximately 5 cents per kilowatthour in $1993 .{ }^{100}$ The reliability of wind turbines has increased from 60 percent availability for machines built in the early $1980 \mathrm{~s}$ to approximately 98 percent for the newest turbine models. ${ }^{101}$ Productivity of turbines, as measured by annual generation per unit area swept by the rotor

${ }^{97}$ S. Williams and B.G. Bateman, Power Plays, p. 256.

${ }^{98}$ U.S. Department of Energy, Office of Energy Efficiency, "Wind Energy Data: Monthly Summary Report" (September 1996$)$, p. 7.

${ }^{99}$ D.F. Ancona, P.R. Goldman, and R.W. Thresher, "Wind Program Technological Developments in the United States," p. 2.

${ }^{100}$ Energy Information Administration, Monthly Energy Review DOE/EIA-0035(95/02) (Washington, DC, February 1995), pP. viii, ix.

${ }^{101}$ U.S. Department of Energy, Wind Energy Program Overview: Fiscal Year 1994, p. 2. 
blades, has risen from 500 kilowatthours per year per square meter to 800 (the average for California's turbines). ${ }^{102}$ The installed cost for a medium-sized turbine has decreased from $\$ 4,000$ per kilowatt in 1980 to $\$ 1,250$ per kilowatt in $1996 .{ }^{103}$ Additionally, operating and maintenance costs have decreased by a factor of 3 , from 3 cents to 1 cent per kilowatthour. Generation costs are also down by a factor of 2, to between 5 and 7 cents per kilowatthour, and are expected to fall to 4 cents per kilowatthour for the next generation of turbines. ${ }^{104}$ (The levelized cost of energy goal of the DOE Wind Energy Program is 2.5 cents per kilowatthour in $15 \mathrm{mph}$ winds by $2000 .{ }^{105}$ ) In terms of net energy use, wind turbines typically repay the energy consumed in their construction in less than a year and, at good sites, in as little as 3 months. ${ }^{106}$

The advance in technological characteristics of wind turbines can be summarized as follows. ${ }^{107}$

Pre-1975: Operating life 1 to 5 years, average capacity factor 10 percent, availability 60 to 70 percent, size range less than 20 kilowatts
Present: Operating life 20 years, average capacity factor 20 to 25 percent, availability 95 percent, size range 200 to 500 kilowatts

Post-2000: Operating life 30 years, average capacity factor 30 percent, availability greater than 95 percent, size range 300 to 1,000 kilowatts.

\section{Conclusion}

Good wind resources are not a constraint to wind power development. Using moderately constraining land use and environmental restriction assumptions, and a 10-mile proximity to existing transmission line assumption, a recent study reported the U.S. potential for over 734,000 average megawatts of wind energy generation capability. ${ }^{108}$ The U.S. share of worldwide wind capacity is declining; however, the domestic market has remained stable even as market uncertainty increases with deregulation and restructuring. Costs continue to decline, and wind energy projects continue to extend into a number of new States.

\footnotetext{
${ }^{102}$ Paul Gipe \& Associates, 1996 Overview of Wind Generation Worldwide, p. 3.

${ }^{103}$ Paul Gipe \& Associates, 1996 Overoiew of Wind Generation Worldwide, p. 3.

${ }^{104}$ S. Williams and B.G. Bateman, Power Plays, p. 262.

${ }^{105}$ U.S. Department of Energy, Office of Photovoltaic and Wind Technologies, 1996.

${ }^{106}$ Paul Gipe \& Associates, 1996 Overview of Wind Generation Worldwide (July 31, 1996), p. 3.

${ }^{107}$ U.S. Department of Energy, Wind Energy Program Overview: Fiscal Year 1994, p. 2.

${ }^{108}$ Energy Information Administration, Monthly Energy Review, DOE/EIA-0035(95/02) (Washington, DC, February 1995), p. xii.
} 



\section{Solar Industry Profile}

\section{Introduction}

The modern solar industry began with the oil embargo of 1973-74 and was strengthened with the second embargo in 1979. The growth of the solar industry during the period of fuel shortages and high prices (1974-1984) soared from 45 solar collector manufacturing firms to 225 firms and from 1.3 million square feet to 17.2 million square feet of production annually. The solar market was helped during this period by government assistance, both Federal and State, mainly in the form of tax credits.

From 1984 to 1986, the number of manufacturing firms in the solar industry declined by 127,109 probably due to the expiration of the 40-percent residential and 15percent business energy tax credits. The decline in industrial companies intensified with the drop in oil prices in 1986. The reinstatement of the business energy tax credit at the 15-percent level for 1986, at the 12percent level for 1987 through 1991, and at the 10-percent level in 1992 and increasing oil prices after 1986 appear to have had little effect on drawing investors and companies into manufacturing solar thermal collectors. Since 1990, the rate of growth of solar collector shipments has stabilized at about 4 percent per year (Table 16 and Figure 18).
Figure 18. Solar Thermal Collector Shipments by Collector Type, 1983-1995

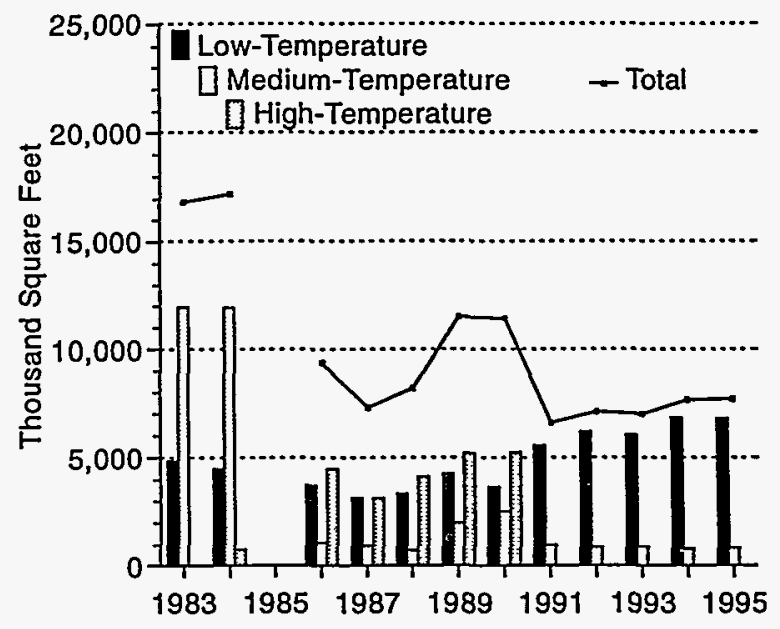

Note: Data for 1985 are incomplete and are not shown. Sources: 1981-1984: Energy Information Administration, Form ElA-63, "Annual Solar Thermal Collector and Photovoltaic Module Manufacturers Survey." 1986-1995: Energy Information Administration, Form EIA-63A, "Annual Solar Thermal Collector Manufacturers Survey."

Table 16. Annual Shipments of Solar Thermal Collectors, 1986-1995

\begin{tabular}{|c|c|c|c|c|c|}
\hline \multirow{2}{*}{\multicolumn{2}{|c|}{ Year }} & \multirow[b]{2}{*}{ Number of Companies } & \multicolumn{3}{|c|}{ Collector Shipments (thousand square feet) ${ }^{a}$} \\
\hline & & & Total & Imports & Exports \\
\hline 1986 & . & 98 & 9,360 & 473 & 224 \\
\hline 1987 & $\ldots$. & 59 & 7,269 & 691 & 182 \\
\hline 1988 & $\ldots$ & 51 & 8,174 & 814 & 158 \\
\hline 1989 & $\ldots \ldots \ldots \ldots \ldots$ & 44 & 11,482 & 1,233 & 461 \\
\hline 1990 & $\ldots \ldots \ldots \ldots \ldots$ & 51 & 11,409 & 1,562 & 245 \\
\hline 1991 & $\ldots \ldots \ldots \ldots \ldots$ & 48 & 6,574 & 1,543 & 332 \\
\hline 1992 & $\ldots \ldots \ldots \ldots$ & 45 & 7,086 & 1,650 & 316 \\
\hline 1993 & $\ldots \ldots \ldots \ldots \ldots$ & 41 & 6,968 & 2,039 & 411 \\
\hline 1994 & $\ldots \ldots \ldots \ldots \ldots$ & 41 & 7,627 & 1,815 & 405 \\
\hline 1995 & $\ldots \ldots \ldots \ldots \ldots$ & 36 & 7,666 & 2,037 & 530 \\
\hline
\end{tabular}

ancludes imputation of shipment data to account for nonrespondents.

Note: Total shipments as reported by respondents include all domestic and export shipments and may include imported collectors that subsequently were shipped to domestic or foreign customers.

Source: Energy Information Administration, Form EIA-63A, "Annual Solar Thermal Collector Manufacturers Survey."

\footnotetext{
${ }^{109}$ Energy Information Administration, Renewable Energy Annual 1995, DOE/EIA-0603(95) (Washington, DC, December 1995).
} 
The "solar cell" or photovoltaic cell was discovered in 1954 by Bell Telephone researchers examining the sensitivity of a properly prepared silicon wafer to sunlight. Beginning in the late 1950s, photovoltaics were used to power U.S. space satellites. The success of photovoltaics in space generated commercial applications for photovoltaic technology that continue to be used and developed today.

Export sales continue to drive the expansion of the photovoltaic industry. Total shipments of photovoltaic cells and modules reached 31 peak megawatts in 1995, a 19-percent increase from 1994 (Table 17 and Figure 19). Exports accounted for 64 percent of total shipments in 1995. The value of photovoltaic cell and module shipments grew by 12 percent in 1995 to $\$ 118$ million, although prices for modules stabilized and prices for cells fell by 17 percent (see Appendix F, Table F18). Shipments for grid-interactive electricity generation doubled, to 4.6 peak megawatts, making 1995 the second straight year in which shipments for this end use have doubled.

\section{Solar Energy Data}

\section{Solar Thermal Collectors}

Since 1974, approximately 233 million square feet of solar thermal collectors have been shipped for eventual installation in the United States (Table 18). Solar thermal collectors are grouped into three categories: low-temperature, medium-temperature, and hightemperature. Assuming an overall efficiency of 50
Figure 19. Import and Export Shipments of Photovoltaic Cells and Modules, 1987-1995

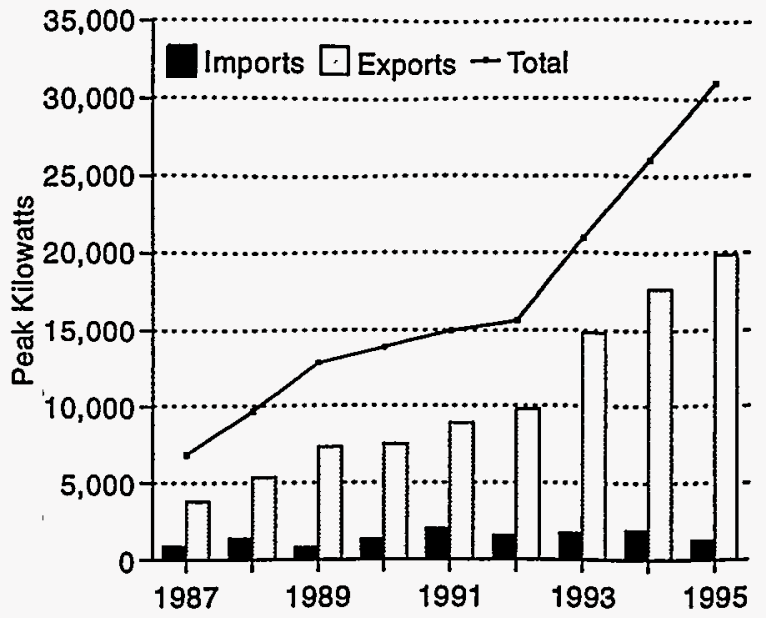

Note: Total shipments as reported by respondents include all domestic and export shipments and may include imports that subsequently were shipped to domestic or foreign customers.

Source: Energy Information Administration, Form EIA-63B, “Annual Photovoltaic Module/Cell Manufacturers Survey.”

percent for all three categories and an average of 1,500 Btu per square foot of daily insolation (solar energy received at the Earth's surface), the potential thermal energy production from the 233 million square feet of solar thermal collectors shipped since 1974 can be estimated at 0.064 quadrillion Btu in 1995. However, this is a simplified approach to the energy calculation. A mildly cloudy day produces about 1,500 Btu of insolation onto an area 1 square foot, but the amount of

Table 17. Annual Shipments of Photovoltaic Cells and Modules, 1985-1995

\begin{tabular}{|c|c|c|c|c|c|}
\hline \multirow{2}{*}{\multicolumn{2}{|c|}{ Year }} & \multirow[b]{2}{*}{ Number of Companies } & \multicolumn{3}{|c|}{ Photovoltaic Cell and Module Shipments (Peak Kilowatts) } \\
\hline & & & Total & Imports & Exports \\
\hline 1985 & $\ldots \ldots$ & 15 & 5,769 & 285 & 1,670 \\
\hline 1986 & $\ldots \ldots \ldots \ldots \ldots$ & 17 & 6,333 & 678 & 3,109 \\
\hline 1987 & $\ldots \ldots \ldots \ldots \ldots$ & 17 & 6,850 & 921 & 3,821 \\
\hline 1988 & $\ldots \ldots \ldots \ldots$ & 14 & 9,676 & 1,453 & 5,358 \\
\hline 1989 & $\cdots \cdots \cdots \cdots$ & 17 & 12,825 & 826 & 7,363 \\
\hline 1990 & $\ldots \ldots \ldots \ldots$ & $b_{19}$ & ${ }^{b} 13,837$ & 1,398 & 7,544 \\
\hline 1991 & $\ldots \ldots \ldots \ldots$ & 23 & 14,939 & 2,059 & 8,905 \\
\hline 1992 & $\ldots \ldots \ldots \ldots \ldots$ & 21 & 15,583 & 1,602 & 9,823 \\
\hline 1993 . & $\ldots \ldots \ldots \ldots \ldots$ & 19 & 20,951 & 1,767 & 14,814 \\
\hline 1994 & & 22 & 26,077 & 1,960 & 17,714 \\
\hline 1995 & $\ldots \ldots$ & 24 & 31,059 & 1,337 & 19,871 \\
\hline
\end{tabular}

aDoes not include shipments of cells and modules for space/satellite applications.

Includes imputed data for one nonrespondent which exited the industry during 1990.

Note: Total shipments as reported by respondents include all domestic and export shipments and may include imported collectors that subsequently were shipped to domestic or foreign customers.

Source: Energy Information Administration, Form EIA-63B, “Annual Photovoltaic Module/Cell Manufacturers Survey.” 


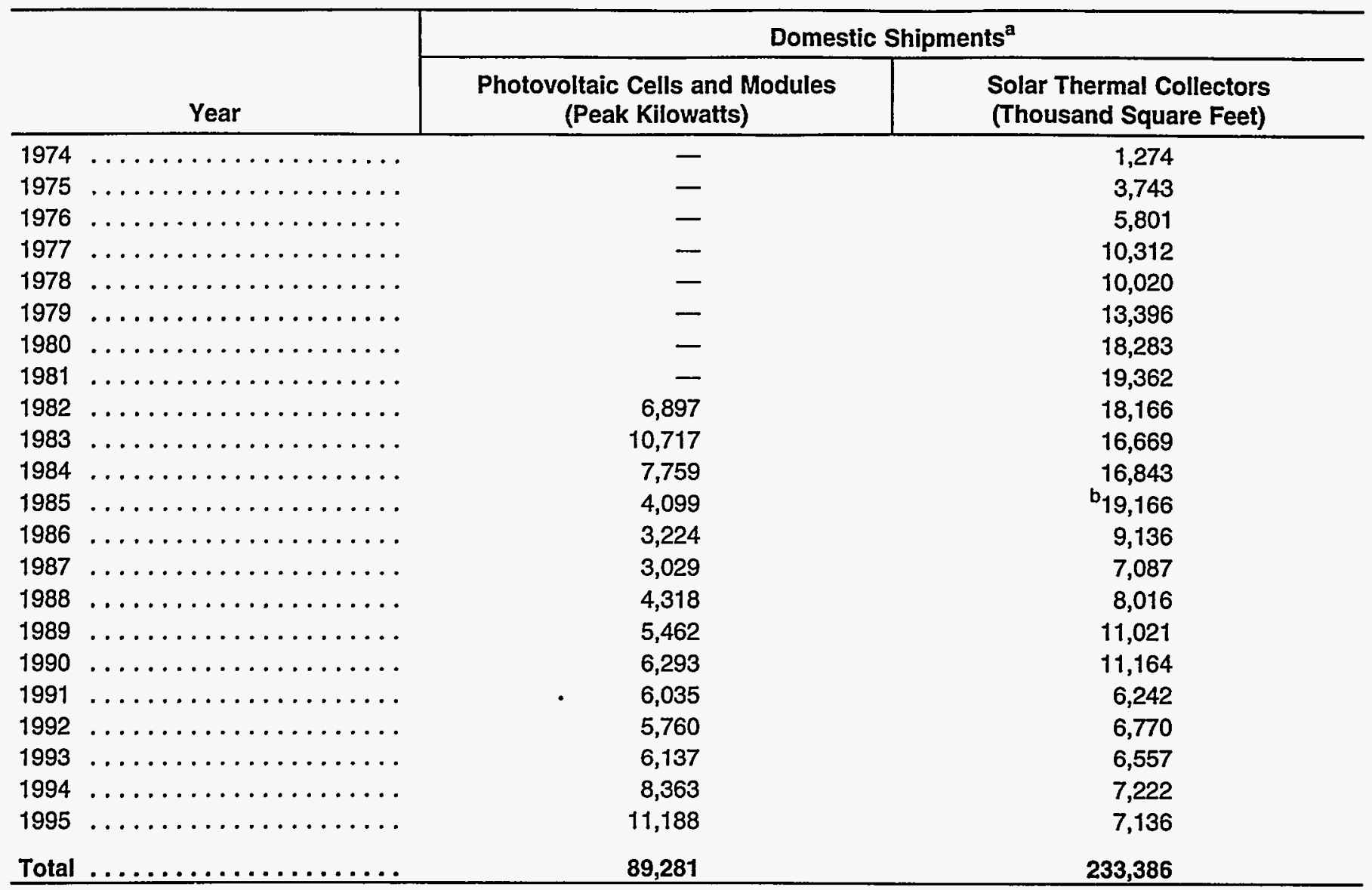

a Total shipments minus export shipments.

'Estimated data.

$-=$ Not available.

Sources: 1974-1977: Federal Energy Administration telephone survey. 1978-1984: Energy Information Administration, Form ElA63, "Annual Solar Thermal Collector and Photovoltaic Module Manufacturers Survey." 1985-1995: Energy Information Administration, Form EIA-63A, "Annual Solar Thermal Collector Manufacturers Survey," and Form EIA-63B, "Annual Photovoltaic Module/Cell Manufacturers Survey."

energy received varies with the changing weather conditions. Retirements are taken into account based on a 20-year average life for collectors, but their impact is minimal because few installed collectors have been in service for 20 years.

U.S. nonutility power producers reported installed capacity of 354 megawatts in 1995, with gross electricity generation of 824 million kilowatthours (equivalent to 0.8 trillion Btu of thermal energy) from solar thermal electric systems. ${ }^{110}$ Nine operating Solar Electric Generating System (SEGS) plants in southern California-SEGS I through IX-accounted for 98 percent (347 megawatts) of the total nonutility solar generating capacity. Nine separate SEGS plants have been constructed by Luz International, Ltd., since 1984. In 1991
Luz ran into financial trouble and filed for Chapter 7 bankruptcy, and the operation of the SEGS plants was taken over by an investor group. A tenth SEGS plant, planned in 1991, was never constructed.

During Luz's existence, the cost of solar electricity was cut from 25 cents per kilowatthour to less than 8 cents per kilowatthour. ${ }^{111}$ SEGS failed economically because: (1) natural gas prices and electricity costs did not rise as expected; (2) operating and maintenance costs for the station did not decline as rapidly as had been expected; and (3) key tax incentives were expiring or uncertain.

The newly renovated Solar Two solar thermal electric generating station, located in California's Mojave

${ }^{110}$ Energy Information Administration, Form EIA-867, "Annual Nonutility Power Producers Report."

${ }^{11}$ D. Escobedo, "Luz Blames Government for Bankruptcy Filings," Public Utilities Fortnightly, Vol. 129, No.2 January 15, 1992). 
Desert, consists of 1,900 motorized mirrors surrounding a generating station with 10 megawatts of capacity, which began operation in early 1996. It is part of an effort to build a commercially viable 100-megawatt solar thermal system by 2000 (see box).

\section{Solar Two Solar Thermal Generating Station}

The 10-megawatt Solar Two solar thermal electric plant near Barstow, CA, began operation in early 1996 on the site of the Solar One plant. Solar Two differs from Solar One primarily in that it includes a molten-salt storage system, which allows for several hours of baseload power generation when the sun is not shining. The molten salt (an environmentally benign combination of sodium nitrate and potassium nitrate) allows a summer capacity factor as high as 60 percent, compared with 25 percent without storage. The plant consists of 1,926 motorized mirrors focused on a 300-foot-high central receiver generating station rated at 10 megawatts. Molten salt from the "cold" salt tank (at $550^{\circ} \mathrm{F}$ ) is heated to $1,050^{\circ} \mathrm{F}$ and stored in the "hot" salt tank. Later the hot salt is passed through a steam generator to produce steam for a conventional steam turbine.

A consortium comprising the U.S. Department of Energy, seven electric utilities (led by Southern California Edison), and several other companies and energy organizations is financing the demonstration. The cost of the plant is approximately $\$ 40$ million for construction and $\$ 9$ million for 3 years of testing and operation (1996-1998). In addition, land and reused structures from the Solar One facility, estimated to have a value of $\$ 140$ million, are part of the project. which is equivalent to 0.001 quadrillion Btu of thermal energy. Retirements had no impact since data collection began in 1984.

U.S. electric utilities reported 3.9 million kilowatthours of net electricity generation from photovoltaic modules in 1995 (Table 19). ${ }^{114}$ Of this total, 93 percent was generated in California ( 70 percent from a single plant). Estimated U.S. total electricity generation was 968.8 million kilowatthours in 1995, and overall estimated energy production in the United States was 71.23 quadrillion Btu (Table 20).

\section{Federal and State Incentives}

The Energy Policy Act of 1992 (EPACT), Section 1916, provides a permanent extension of the energy investment tax credit for solar property retroactive to June 30 , 1992. Investors in or purchasers of qualified solar energy property can take the credit on up to 10 percent of the investment or purchase price and installment amount. Section 1212 applies an electricity production incentive of 1.5 cents per kilowatthour for solar energy generation sold by municipal electric utilities, rural cooperative utilities, and other public agencies.

At the end of 1995, approximately 30 States had official policies encouraging the development of solar energy and provided financial incentives for investment in the use of solar thermal collectors and photovoltaic modules and cells. ${ }^{115}$ Three States-Hawaii, Iowa, and Washington-approved financial incentives during 1996. The legislative actions were passed to encourage the use of an environmentally clean source of energy, to promote energy conservation through the use of renewable energy technologies, and to promote energy efficiency. Among the most common incentives were property tax exemptions and income tax credits for both the residential and business sectors.

\section{Technology Characterization}

Since 1982, approximately 89 peak megawatts of photovoltaic cells and modules have been shipped for eventual installation in the United States (Table 18). ${ }^{112}$ Assuming a 27.5-percent capacity factor, ${ }^{113}$ the potential energy production in 1995 from the 89 peak megawatts was about 214,400 megawatthours of electricity,
Solar energy technologies are separated into two major classifications by type of energy used: solar thermal devices, which use the sun's heat, and photovoltaic cells and modules, which use the energy inherent in solar photons and convert it directly to electricity.

\footnotetext{
${ }^{112}$ Energy Information Administration, Renewable Energy Annual 1995, DOE/EIA-0603(95) (Washington, DC, December 1995).

${ }^{113}$ US Department of Energy, "The Potential of Renewable Energy: An Interlaboratory White Paper" (Washington, DC, March 1990), P. G-5.

${ }^{114}$ Net generation is gross generation minus plant use.

${ }^{115}$ M.H. Brown and B. Foster, State Incentives for Renewable Energy Resources that Generate Electricity (Draft) (Denver, CO: National Conference of State Legislatures, August 7, 1996).
} 
Table 19. U.S. Utility Net Electric Generation from Solar Energy, 1995

(Thousand Kilowatthours)

\begin{tabular}{|c|c|c|}
\hline Utility & Plant (State) & Net Generation \\
\hline Sacramento Municipal Utility District & Solar (California) & 2,753 \\
\hline Austin Electric $\ldots \ldots \ldots \ldots \ldots \ldots$ & Decker Creek (Texas) & 253 \\
\hline Pacific Gas \& Electric . . . . . . & PVUSA 1 (California) & 900 \\
\hline Virginia Electric Power & North Anna (Virginia) & 3 \\
\hline Total .... & & 3,909 \\
\hline
\end{tabular}

Source: Energy Information Administration, Electric Power Monthly, DOE/EIA-0226(93/04) (Washington, DC, April 1996), Table 58.

Table 20. Estimated U.S. Solar and Total Energy Production, 1995

(Quadrillion Btu)

\begin{tabular}{|c|c|}
\hline $\begin{array}{l}\text { Activity, Production Sector, } \\
\text { and Solar Energy Resource }\end{array}$ & $\begin{array}{c}\text { Energy } \\
\text { Production }\end{array}$ \\
\hline \multicolumn{2}{|l|}{$\begin{array}{l}\text { Solar Energy Production To Generate } \\
\text { Electricity }\end{array}$} \\
\hline Electric Utilities: Photovoltaic . . . . . . . & $<0.005$ \\
\hline $\begin{array}{l}\text { Nonutility Power Producers: } \\
\text { Solar Thermal-Electric . . . . . . . . . . }\end{array}$ & 0.01 \\
\hline End Users: Photovoltaic $\ldots \ldots \ldots \ldots$ & $<0.005$ \\
\hline \multicolumn{2}{|l|}{$\begin{array}{l}\text { Solar Energy Production To Generate } \\
\text { Thermal Energy }\end{array}$} \\
\hline End Users: Solar Thermal ... & 0.06 \\
\hline $\begin{array}{l}\text { Estimated Total U.S. Solar Energy } \\
\text { Production } \ldots \ldots \ldots \ldots \ldots \ldots \ldots\end{array}$ & 0.07 \\
\hline $\begin{array}{l}\text { Adjusted Total U.S. Energy Production } \\
\text { Estimate }^{\mathrm{a}} \ldots \ldots \ldots \ldots \ldots \ldots \ldots \ldots \ldots\end{array}$ & 71.23 \\
\hline
\end{tabular}

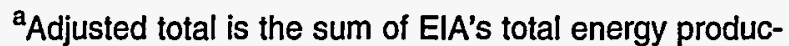
tion data of 71.16 quadrilion Btu (Annual Energy Review 1995, Table 1.2) and estimated solar energy production of 0.07 quadrillion Btu.

Source: Energy Information Administration, Form EIA63A, "Annual Solar Thermal Collector Manufacturers Survey," Form EIA-63B, "Annual Photovoltaic Module/Cell Manulacturers Survey," Form EIA-759, "Monthly Power Plant Report," and Annual Energy Review 1995, DOEI ElA-0384(95) (Washington, DC, July 1995), Tables 1.2 and 8.12 .

\section{Solar Thermal}

Solar thermal systems collect the thermal energy in solar radiation for direct use in low- to high-temperature thermal applications. High-temperature solar thermal electric technologies work by concentrating large amounts of sunlight onto a smaller area to achieve high temperatures, which are then converted to electricity by various means, including conventional steam-cycle technology. High-temperature applications operate at temperatures above $180^{\circ} \mathrm{F}$.

The leading solar thermal electric technology is the parabolic trough, which focuses sunlight on a tube that carries a heat-absorbing fluid, usually oil. The fluid is circulated through a boiler, where its heat is used to boil water to steam, and the steam is routed to a turbine to generate electricity. More than 350 megawatts of parabolic-trough electric generating capacity, connected to the Southern California Edison Company (SCE) utility grid, is operating in California's Mojave Desert.

Central-receiver techndlogy plants use a field of mirrors to focus the sun's energy on a central receiver, which is mounted on a tower. An experimental 10-megawatt central receiver power plant, Solar One, was built and operated in Barstow, California, during the 1980 s by a government-industry team. A newly refurbished plant, Solar Two, with an improved conversion technology, began operations in early 1996. Improvements in Solar Two relative to Solar One include a higher efficiency receiver system and high efficiency/low cost thermal energy storage. The receiver transfers the solar energy to a molten-salt liquid, which flows through tubes located in the receiver and then either directly to a tank located at the bottom of the tower for storage or to a heat exchanger to produce steam for electric output. Storage greatly enhances the attractiveness of this technology, in that it allows utilities to schedule electricity at times when the sun is not shining and eliminates disruptions in the plant output due to temporary cloud conditions. Solar Two is designed as a pilot-scale proof of concept, not a cost-competitive prototype (see box on page 52).

The third solar thermal electric technology, the dish/ engine system, comprises a parabolic concentrator (dish), a thermal receiver, and a heat engine/generator. The system operates by tracking the sun and reflecting the solar energy to the focus of the dish, where it is 


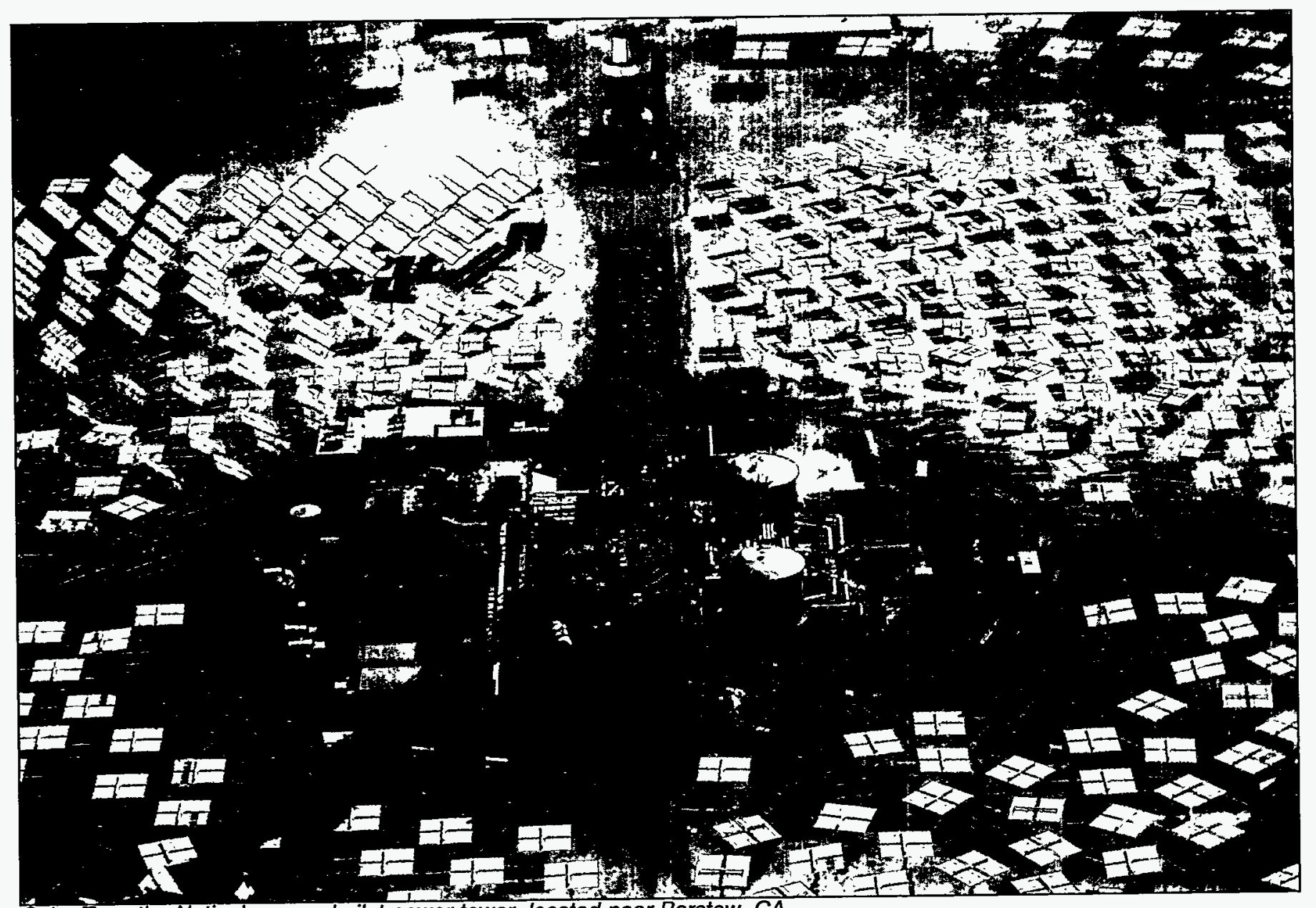

Solar Two, the Nation's second pilot power tower, located near Barstow, CA.

absorbed by the receiver. The absorbed heat is then transferred by the receiver working fluid (often liquid sodium) to the engine/generator. The typical engine used in these systems is the Stirling engine. Dish/ engine modules can range in size from about 5 to 40 kilowatts; multiple dishes can be used to form power plants of any size. Dish/engine technology has been demonstrated in a variety of complete systems over the past dozen years, and may move into early commercial applications in the next few years.

Low-temperature solar collectors provide heat up to $110^{\circ} \mathrm{F}$ through either metallic or nonmetallic absorbers. Low-temperature solar applications include the heating of water for swimming pools.

Medium-temperature collectors provide heat greater than $110^{\circ} \mathrm{F}$ (usually 140 to 180 ) through glazed flat-plate collectors that use air either or liquid as the heat transfer medium. Medium-temperature collectors are used for water, space, and process heating. Evacuated tube collectors are included in this category.

\section{Photovoltaic Cells and Modules}

Photovoltaic energy technology involves the direct conversion of light into electricity by means of a solid-state device, the photovoltaic cell, which converts sunlight into electricity. Sunlight is composed of photons, infinitesimally small packets of radiant energy. When photons strike a photovoltaic cell, some packets are absorbed, generating electricity. The energy of a photon is transferred to an electron in an atom of the semiconductor device. The cell is composed of thin layers of semiconductor material that produce electricity when exposed to light. When electrical contacts are attached to the layers and the circuit is completed, an electrical current flows. To protect them from the environment, cells are linked together and encapsulated in modules, which are used in various applications.

Photovoltaic technology options can be divided into two categories: cell technology and module/array technology. Photovoltaic cell technologies include singlecrystal Czochralski silicon, semicrystalline silicon, 
polycrystalline thin-film, and amorphous silicon. Photovoltaic module/array technologies include flat-plate and concentrator modules. The most common photovoltaic cells are made from single crystal silicon wafers. During 1995. U.S. shipments of single-crystal silicon cells and modules amounted to 19.9 million peak kilowatts, or a 63-percent market share, up from a 54-percent market share in 1990. Polycrystalline silicon cells are made by cast and ribbon production techniques. In 1995 they garnered a 31-percent market share, down from 36 percent in 1990. Amorphous silicon cells are based on amorphous silicon thin film, made from layers of randomly arranged noncrystalline silicon material deposited on a glass or other substrate, through a continuous and inexpensive process. U.S. shipments of amorphous silicon cells in 1995 were 1.3 million peak kilowatts or 4 percent of total shipments.

Photovoltaic modules are composed of an integrated array of photovoltaic cells assembled into a flat panel. The cell surface is encapsulated with a transparent covering that transmits sunlight to the cell and protects the cell from water and dirt damage. Concentrator arrays consist of one or more lenses that focus and concentrate incident sunlight on one or more photovoltaic cells.

\section{Industry Activity in 1995}

The following paragraphs present a summary of 1995 activity in the U.S. solar energy industry, based on data collected by the Energy Information Administration on Form EIA-63A, "Annual Solar Thermal Collector Manufacturers Survey," and Form EIA-63B, "Annual Photovoltaic Module/Cell Manufacturers Survey." Detailed data from the surveys are presented in Appendix F, "Additional Solar and Photovoltaic Data Tables." The tables in Appendix $\mathrm{F}$ are referenced below.

\section{Solar Thermal Collectors}

In 1995, 36 companies were active in the solar thermal collector manufacturing industry, a decline of 12 percent from 1994. They shipped collectors totaling approximately 7.7 million square feet during the year (Table 16), a 1-percent increase from 1994. Six companies were planning to introduce new low-temperature collectors, 13 were planning new medium-temperature collectors, and 6 were planning to introduce new hightemperature collectors in 1996 (Appendix F, Table F1).

Since 1987, the 10 largest U.S. companies that shipped solar thermal collectors have supplied not less than 95 percent of all solar thermal collectors manufactured in or imported into the United States (Table F2). In 1995,
96 percent of the approximately 7.7 million square feet of total shipments were supplied by the 10 largest companies. In the period 1982 to 1984 , the average share of the 10 largest companies was 50 percent of total shipments.

In 1995 employment in solar-thermal-related activities decreased to 386 person-years, a 4-percent drop from the 1994 employment level of 402 person-years. Industry employment data for 1992 through 1995 are as follows:

\begin{tabular}{cc} 
Year & Person-Years Expended \\
\hline 1992 & 449 \\
1993 & 392 \\
1994 & 402 \\
1995 & 386
\end{tabular}

Most of the 36 reporting companies in 1995 combined manufacturing and related activities with imports of solar thermal collectors:

- A total of 28 companies were involved in design of collectors or systems, 17 were developing prototype collectors, and 13 were developing prototype systems (Table F3).

- There were 24 wholesale companies and 16 retail companies. Of the 36 companies, 15 offered installation of their collectors.

Solar-related sales represented 90 to 100 percent of total company sales for 22 companies in 1995, up from 24 companies in 1994 (Table F4). Solar-related sales made up less than 10 percent of total sales for 4 companies in 1995, compared with 3 companies in 1994.

\section{Shipments}

Solar thermal collector shipments totaled approximately 7.7 million square feet in 1995, a 1-percent increase from the 1994 level of approximately 7.6 million square feet (Table 16). Import shipments totaled 2.0 million square feet and export shipments were 0.5 million square feet in 1995 (Figure 20). Shipments of lowtemperature solar thermal collectors were roughly constant in 1994 and 1995 at about 6.8 million square feet (Figure 18 and Table F5). Shipments of mediumtemperature collectors increased by 5 percent to 0.84 million square feet in 1995 from 0.80 million square feet in 1994. Shipments of high-temperature collectors increased from 2,000 square feet in 1994 to 13,000 square feet in 1995 (Table F5).

\section{Origins}

U.S. manufacturers in California, New York, New Jersey, Florida, and Puerto Rico produced 89 percent of 
Figure 20. Import and Export Shipments of Solar Thermal Collectors, 1983-1995

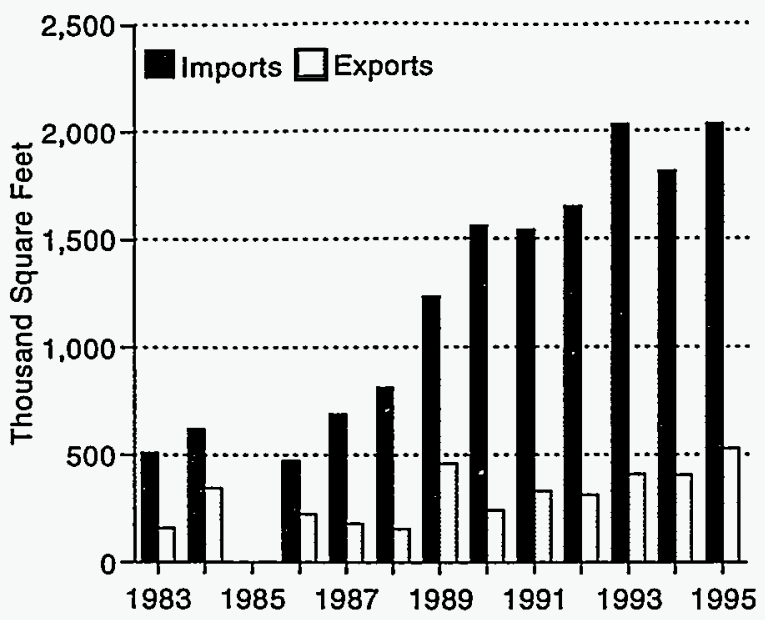

Notes: Total shipments as reported by respondents include all domestic and export shipments and may include imports that subsequently were shipped to domestic or foreign customers. Data for 1985 are incomplete and are not shown.

Sources: 1981-1984: Energy Information Administration, Form EIA-63, "Annual Solar Thermal Collector and Photovoltaic Module Manufacturers Survey." 1986-1995: Energy Information Administration, Form EIA-63A, "Annual Solar Thermal Collector Manufacturers Survey."

U.S.-manufactured collectors in 1995, the same as in 1994. California continued to lead the Nation in 1995 with 32 percent of total domestic shipments. Shipments of U.S.-manufactured solar thermal collectors in 1995, which totaled 4.9 million square feet, originated from 17 States and Puerto Rico. Florida received the largest number of collectors, 50 percent of shipments (Table F6). New York, New Jersey, and Puerto Rico shipped a combined 2.7 million square feet in 1995.

\section{Distribution}

Of total shipments in 1995, 69 percent were sent directly to wholesale distributors and 22 percent were sent to retail distributors (Table F7). Of export shipments, 53 percent were sent directly to exporters. Direct shipments to installers, end users, and others accounted for 6 percent of total shipments in 1995.

\section{Quantity, Values, and Prices}

Low-temperature collectors dominated the solar thermal industry in 1995, accounting for 89 percent of total shipments (Table F5). Medium-temperature collectors accounted for 11 percent of total collector shipments in
1995. Flat-plate (medium-temperature) collectors represented 9 percent of total shipments. High-temperature collectors, shipped primarily for research and demonstration projects, represented less than 1 percent of total shipments in 1995.

The total value of solar thermal collector shipments was $\$ 25.2$ million in 1995, an 11-percent decrease compared with 1994 (Table F8). The average price of low-temperature collectors decreased to $\$ 2.31$ from $\$ 2.53$ (dollars per square foot), and the average price of internal collector storage (ICS) and thermosiphon collectors decreased to $\$ 19.73$ in 1995 from $\$ 26.10$ in 1994 (Figure 21). This decrease was due primarily to decreased material costs. The average price for flat-plate collectors in 1995 decreased to $\$ 8.09$ from the corresponding 1994 level of $\$ 8.79$ per square foot. ${ }^{116}$

\section{Figure 21. Average Price of Solar Thermal Collector Shipments by Collector Type, 1994 and 1995}

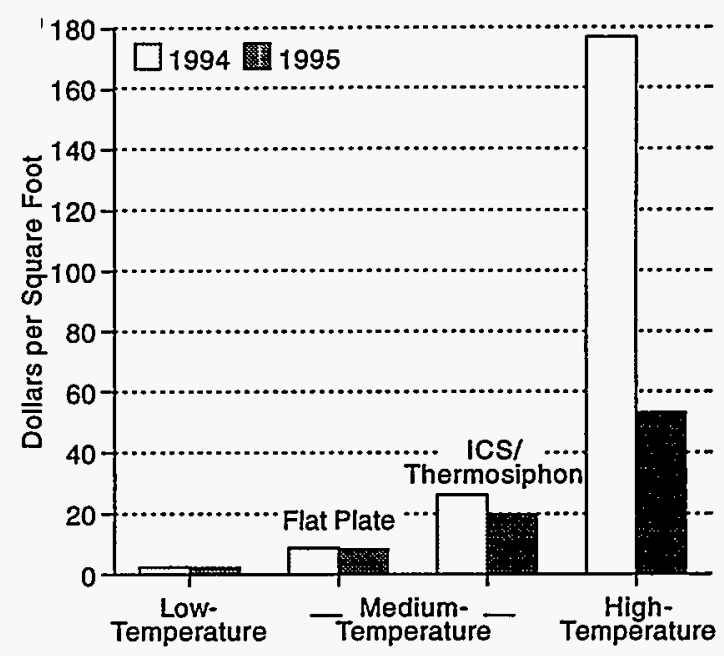

Note: See Appendix F, Table F6, for data values.

Source: Energy Information Administration, Form EIA-63A, "Annual Solar Thermal Collector Manufacturers Survey."

\section{Markets}

In 1993, the residential sector was the largest market for solar thermal collectors. Solar thermal collectors shipped to the residential sector in 1995 totaled 7.0 million square feet, 91 percent of total shipments (Table F9). This market sector primarily involves the use of low-temperature solar collectors for heating swimming pools and medium-temperature collectors for water heating in residential buildings. The residential sector was also the largest market in 1994 . The second-largest

\footnotetext{
${ }^{116}$ The value of shipments includes charges for advertising and warranties. Excise taxes and the cost of freight or transportation for the shipments are excluded.
} 
market for solar thermal collectors in 1995 was the commercial sector, which accounted for 8 percent of total shipments.

\section{Uses}

The largest end use for solar thermal collectors shipped in 1995 was for heating swimming pools, representing 88 percent of the total square feet shipped, or $6.8 \mathrm{mil}-$ lion square feet (Table F9). This application usually involves the use of low-temperature collectors. A common low-temperature pool-heating solar collector is a black plastic or rubber-like sheet with tubing through which water is circulated. The heat of the sun is transferred directly from the black absorbing material to the water circulating through the tubing to supply heat to the pool. Shipments for pool heating decreased by 1 percent in 1995 from the level reported in 1994.

The second-largest end use in 1995 was for domestic hot water systems, which accounted for 10 percent of the total square feet shipped, or 0.8 million square feet. Typical solar water-heating systems feature flat-plate collectors or collectors installed in an ICS or thermosiphon system. Unlike pool-heating systems, domestic solar water-heating systems nearly always have a conventional backup (i.e., gas or electric). Shipments in 1995 for hot water systems decreased by 4 percent from the 1994 level. Medium-temperature collectors also were shipped for space heating, and for installation into systems that provide both space and water heating and process heating. High-temperature parabolic dish and trough collectors were shipped for electricity generation and other end uses in 1995.

\section{Destinations}

Domestic. Solar thermal collectors were shipped to 41 States, Puerto Rico, and the U.S. Virgin Islands in 1995 (Table F10). In 1994, 42 States received collector shipments. The four States and one U.S. territory that received the largest amounts of solar thermal collectors in 1995 were Florida (50 percent), California (20 percent), Arizona ( 4 percent), Hawaii ( 3 percent), and Puerto Rico ( 2 percent) (Table F6). All of the collectors manufactured in Puerto Rico remained on the island. The U.S. market for solar thermal collectors continued to be highly concentrated in a few States and Puerto Rico. Factors favorable for solar energy use that these States and Puerto Rico have in common are: (1) good solar insolation; (2) high electricity costs; (3) solar-promoting incentives, such as tax credits or exemptions; and (4) a demand for low-technology solar pool heaters and solar domestic hot water systems.

Exports. Exports accounted for 7 percent of total shipments in 1995. A total of 19 companies exported solar thermal collectors in 1995, compared with 16 companies in 1994. Low-temperature collectors accounted for 24 percent and medium-temperature collectors 73 percent of 1995 exports. By region, the largest percentages of shipments were to the Americas (52 percent), followed by Asia and the Middle East (19 percent) and Europe (23 percent) (Table F11). Trading countries that received export shipments were Taiwan (15 percent), Japan (10 percent), Australia (9 percent), Mexico (9 percent), Austria (8 percent), Canada (7 percent), and France (6 percent) (see Chapter 12 of this report).

\section{Systems}

Of the 36 companies reporting shipments of solar thermal collectors in 1995, 31 reported shipments of 14,121 complete solar thermal collector systems. ${ }^{117}$ This was an 11-percent decrease compared with 1994 (Table F12). The 14,121 complete systems accounted for 1.6 million square feet of collectors, an decrease of 44 percent in square feet shipped from the 1994 level. The total value for the systems shipped in 1995 was $\$ 17.8$ million, compared with $\$ 19.4$ million in 1994.

\section{Photovoltaic Cells and Modules}

\section{Manufacturing Activities}

Photovoltaic cells are typically classified as, crystalline "thick-film" cells, thin-film cells, and concentrator cells. The last type is used in conjunction with a lens or focusing mirror that concentrates the sunlight on a small area. The majority of today's power applications are crystalline "thick-film" cell technology. Three types of the cells are now in production: the original singlecrystal wafer, polycrystalline cells, and cells from "sheet" technology.

Photovoltaic cell and module shipments totaled 31.1 peak megawatts in 1996 (Table 17 and Figure 22). These shipments were reported by 24 companies, an increase of two companies from 1994. Four companies expect to introduce new crystalline-silicon module products, while eight companies reported plans to introduce new thin-film products to the industry during 1996 (Table F13). Two companies reported plans to produce new photovoltaic concentrator products and two planned new nonmodule system components during 1996.

\footnotetext{
${ }^{117}$ A complete system is a unit with a collector and all the necessary functional components, except for installation materials. Included are thermosiphon systems, integral collector storage systems, packaged systems, and system kits.
} 
Figure 22. Domestic and Export Shipments of Photovoltaic Cells and Modules, 1987-1995

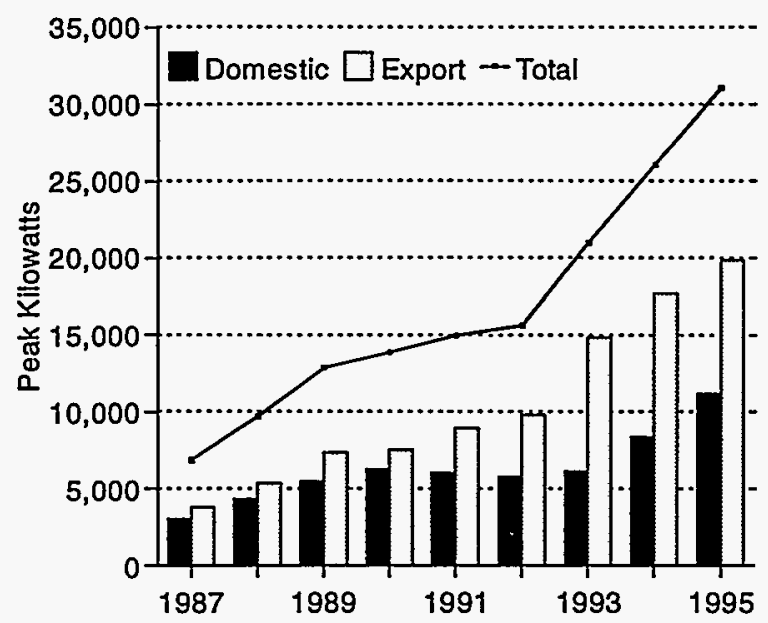

Notes: Total shipments as reported by respondents include all domestic and export shipments and may include imports that subsequently were shipped to domestic or foreign customers. See Table 17 for data values.

Source: Energy Information Administration, Form ElA-63B, "Annual Photovoltaic Cell/Module Manufacturers Survey."

Employment in photovoltaic-related activities totaled 1,578 person-years in 1995 (Table F14), an increase of 266 person-years from the 1994 level of employment. The average employment per company was 66 personyears in 1995, compared with 60 person-years in 1994.

Many companies that are engaged in manufacturing and/or importing photovoltaic cells and modules reported in the 1995 survey that they also were involved in other related activities. Nineteen companies were involved in module or system design, 17 were active in development of module prototypes, and 14 were active in development of system prototypes (Table F15). Fourteen companies sold wholesale and 6 companies sold at retail. Eight companies, two less than in 1994, installed photovoltaic cells or modules.

\section{Shipments}

Of the 31.1 peak megawatts of photovoltaic cell and module shipments in 1995 (Table F16), module shipments accounted for 19.6 peak megawatts and cell shipments accounted for 11.4 peak megawatts. Total shipments in 1995 increased by 19 percent from the 1994 level. Total shipments have increased by 538 percent since 1985 (Table 17). Data for cells and modules for terrestrial use only (i.e., excluding space applications) have been reported each year since 1985 .

\section{Imports}

Eight companies reported import shipments of photovoltaic cells and modules in 1995 totaling 1.3 peak megawatts, or 4 percent of total shipments. The predominant type of imported cells and modules was crystalline silicon. Ninety-nine percent of the imports originated in Japan.

\section{Distribution}

In 1995, photovoltaic cell and module shipments totaling 16.4 peak megawatts (53 percent of total shipments) were sent directly to wholesale distributors (Table F17). Installers and end users combined received 4.6 peak megawatts (15 percent of total shipments). Cell manufacturers shipped 5.8 peak megawatts (19 percent of total shipments) to other companies that manufacture (assemble) cells into modules.

\section{Cell and Module Types}

Photovoltaic shipments are divided into three categories by product type: (1) crystalline silicon cells and modules (includes single-crystal, cast silicon, and ribbon silicon); (2) thin-film cells and modules (made from a number of layers of photosensitive materials such as amorphous silicon); and (3) concentrator cells and modules (in which a lens is used to gather and converge sunlight onto the cell or module surface).

Crystalline silicon cells and modules continued to dominate the industry in 1995, accounting for 96 percent of total shipments (Table F16). In particular, singlecrystal silicon shipments totaled 19.9 peak megawatts, an increase of 20 percent compared with corresponding 1994 shipments (Figure 23). Together, cast and ribbon silicon shipments totaled 9.9 peak megawatts in 1995, a 20-percent increase from the corresponding 1994 shipments. From 1994 to 1995, thin-film shipments increased by 19 percent (Table F16). Thin-film shipments represented 4 percent of total shipments in 1995.

\section{Values and Prices}

The total value of photovoltaic cell and module shipments was $\$ 118$ million in 1995, a 12-percent increase over the 1994 value of $\$ 106$ million (Table F18). ${ }^{118}$ The total value of crystalline silicon (single-crystal, cast, and ribbon) shipments was $\$ 109.5$ million in 1995, a 15-percent increase compared with the corresponding 1994 value. The value of thin-film shipments in 1995 was $\$ 8.8$ million, 19 percent more than in 1994 . The average price of crystalline silicon modules in 1995 was $\$ 4.39$ per peak watt, a 4-percent increase from the 1994 price

\footnotetext{
${ }^{118}$ The total value includes charges for advertising and warranties, but does not include excise taxes and the cost of freight or transportation for the shipments.
} 
Figure 23. Photovoltaic Cell and Module Shipments by Type, 1993-1995

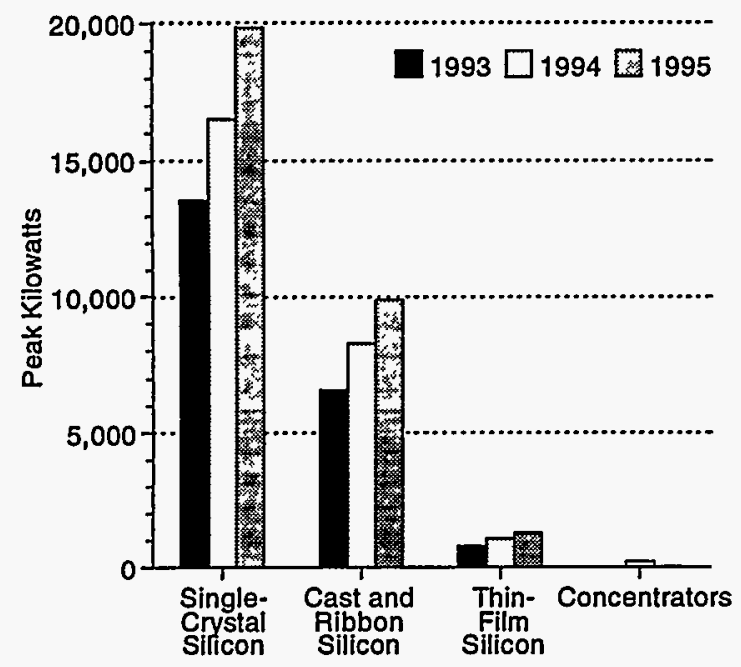

Source: Energy Information Administration, Form EIA-63B, "Annual Photovoltaic Cell/Module Manufacturers Survey."

of $\$ 4.22$ (Figure 24). The average price for thin-film modules was $\$ 7.00$ per peak watt, the same as in 1994 .

\section{Uses}

The largest end-use application of photovoltaic cells and modules in 1995 was for electricity generation (combined grid-interactive and remote), which represented 41 percent of total shipments (Table F19). Of the 12.8 peak megawatts represented by this end use, 97 percent involved crystalline silicon cells and modules. Grid-interactive and remote (i.e., standalone) power generation uses included applications for grid distribution and general remote uses, such as residential power and power for mobile homes.

The second-largest end use in 1995 was in the communication sector, which accounted for 5.2 peak megawatts. Transportation end-use application accounted for 4.2 peak megawatts, or 14 percent of total shipments. In 1995, use of photovoltaics in the transportation sector increased by almost 98 percent from 1994. End uses related to water pumping and original equipment manufacturers accounted for 2.7 peak megawatts and 3.2 peak megawatts, respectively, in 1995 and involved primarily the use of crystalline silicon cells and modules.

Sales for consumer goods accounted for 1.0 peak megawatts in 1995, a decline of 68 percent from 1994. Cells and modules used for health and medical purposese.g., to power refrigerators, medical equipment, and water purifiers-totaled 0.8 peak megawatts in 1995, a tenfold increase over the 1994 level. End uses reported
Figure 24. Average Price of Photovoltaic Cell and Module Shipments by Type, 1993-1995

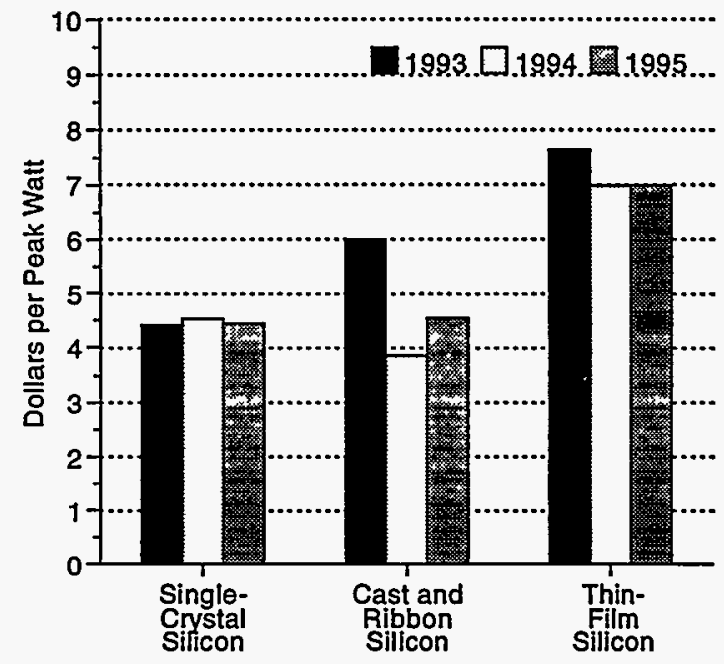

Source: Energy Information Administration, Form ElA-63B, "Annual Photovoltaic Cell/Module Manufacturers Survey."

as "Other" for 1995 totaled 1.2 peak megawatts, 5 times as much as 1994.

\section{Destinations}

Domestic. The commercial sector was the largest market for photovoltaic cells and modules in 1995, accounting for 26 percent of total shipments, or 8.1 peak megawatts (Table F19). These cells and modules were shipped to provide power for commercial establishments such as office buildings, retail establishments, private hospitals, and schools (publicly owned hospitals and schools are listed under the government sector). In 1995, 96 percent were crystalline silicon and 4 percent were thin-film silicon cells and modules.

The industrial sector represented the largest market for photovoltaic shipments in 1994, whereas the use of cells and modules in grid-connected and remote systems to provide power for the industrial sector was the secondlargest market in 1995, accounting for 23 percent of total shipments. The residential market was the thirdlargest market in 1995, accounting for 20 percent of total shipments in 1995. In 1994, the residential sector was the second-largest market at 25 percent of total shipments.

Photovoltaic cells and modules for the transportation sector, which were used to produce power on boats, in cars, in recreational vehicles, and to power transportation support systems, amounted to 2.4 megawatts. The transportation sector accounted for 8 percent of total shipments in 1995, the same as in 1994. Shipments 
to the utility sector, where cells and modules were used to produce power at utility-owned systems including central stations, decentralized systems, and experimental applications, amounted to 3.8 peak megawatts in 1995, a 59-percent increase from 1994.

Shipments of cells and modules used to produce power at installations of Federal, State, or local governments (excluding military) totaled 2.0 peak megawatts in 1995, compared with 2.1 peak megawatts shipped to the government sector in 1994. The "Other" sector (Table F19) in 1995 consisted of 1.3 peak megawatts shipped to foreign governments or used for specialty purposes, an increase of 164 percent from 1994.

Exports. Export shipments totaled 20 peak megawatts in 1995 (Table F20), an increase of 12 percent from the 1994 level. (Export shipments to individual countries are listed in Chapter 12.) Generally, export shipments since 1990 have paralleled total shipments because of the continued search for new markets outside the United States (Figure 22). A total of 18 companies reported exports of cells and modules in 1995, as exports accounted for 64 percent of total shipments. Of all types of cells and modules exported in 1995, 98 percent were crystalline silicon. Almost one-half ( 49 percent) of the photovoltaic cells and modules exported were shipped to Asia, and 28 percent were shipped to European countries (Table F21).

\section{Systems}

Of the 24 companies that reported shipments of photovoltaic systems in 1995, 15 reported shipments of 1,077 complete systems, ${ }^{119}$ less than one-half the number shipped in 1994 (Table F22). Some complex, large-scale systems use concentrators to focus incident insolation onto small photovoltaic cells and tracking systems to track the sun. In this report, installation materials such as the support frame and concrete foundations are not considered as part of a system. The value of systems reported in Table F22 excludes excise taxes and charges for freight, transportation, and installation. The total value of complete systems shipped in 1995 was $\$ 6.4$ million. Complete-system shipments in 1995 accounted for 0.9 peak megawatts, or 3 percent of total module shipments.

\section{Activities in 1996}

The following paragraphs summarize major activities in the U.S. solar power industry in 1996.
The National Renewable Energy Laboratory (NREL) in Golden, CO, set a world record sunlight-to-energy efficiency of 17.7 percent in 1996 for thin-film photovoltaics using copper indium gallium diselenide (CIGS). The achievement in this next-generation replacement for existing photovoltaic technologies is about 60 percent higher than the equivalent efficiency of commercial thin-film photovoltaics made from amorphous silicon. Amorphous silicon has been getting considerable attention as new production facilities are being opened in the United States, and power purchase agreements are being signed between U.S. companies and foreign governments.

Amoco/Enron Solar Power Development signed a 25year power purchase agreement with the Rajasthan (India) State Electricity Board for the sale of up to 50 megawatts of electricity generating capacity from what is expected to be the world's largest photovoltaic power plant, to be built in the Thar desert near Jaisalmer in Rajasthan state. The accord was signed 3 months after the two parties signed a letter of intent calling for the power to be bought on an escalating scale beginning at about 8 cents per kilowatthour. The same kind of modules will also be used to build a Hawaiian power plant in 1997, which is expected to be at full capacity by the middle of the year.

Helicol Corporation of Clearwater, FL, in late March 1996 completed the installation of a solar pool-heating system spanning more than 10,000 square feet at the aquatic center of the Georgia Institute of technology, where the 1996 summer olympic swimming and diving competitions were held. Because of the natatorium's unique type of standing-seam, rib-roofing construction, no roof penetrations were used on most of the panels. A special roof clip was used for flush mounting, and special aluminum racks were built for $72 \mathrm{HC}-50$ panels. The 50-meter competition pool contained 1 million gallons of water, which was pumped through the Helicol collectors at 600 gallons per minute by a 40 -horsepower three-phase pump. The pool water was kept within a margin of 1 degree during the competition. Richard Long, architect at Georgia Tech, estimated that the system would save $\$ 12,000$ per year in utility bills.

Amoco/Enron Solar in Frederick, MD, was also expected to be selected to provide a polycrystalline building-integrated photovoltaic array with a capacity of approximately 312 peak kilowatts at the olympic natatorium - the largest such array in the United States. A second project, with a capacity of 9 kilowatts featuring new 240-watt Solarex architectural modules, was

\footnotetext{
${ }^{119} \mathrm{~A}$ complete photovoltaic system is defined as a power supply unit that satisfies all the power requirements of an application. Such a system is generally made up of one or more modules, a power conditioning unit to process the electricity into the form needed by the application, wires and other electrical connectors, and sometimes batteries for back-up power supply.
} 


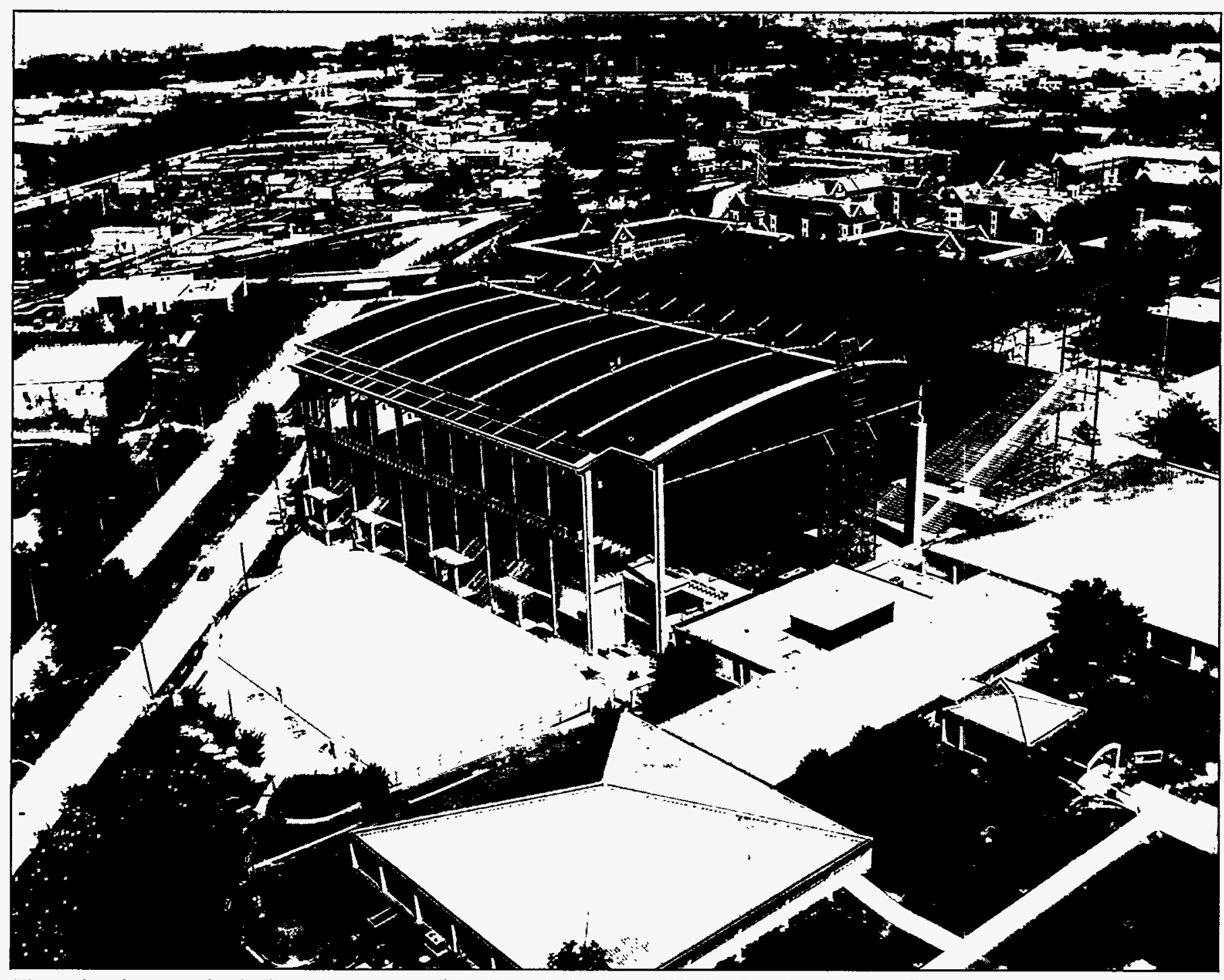

The swimming complex built on the campus of the Georgia Institute of Technology for the 1996 Summer Olympic Games features a large-scale solar electric (PV) system that supplies about 30 percent of the total electricity needs at the complex.

slated for the roof covering the walkway to the main entrance of the athletic center. Funding for the project was provided by the U.S. Department of Energy, Georgia Tech, and the Georgia Power Corporation, with design assistance from Solar Design Associates of Harvard, MA.

Four projects were selected in 1996 for immediate development of up to 270 megawatts of renewable energy in the southern Nevada Solar Enterprise Zone (SEZ). The Corporation for Solar Technology and Renewable Resources (CSTRR) of Las Vegas, NV, the agent for finding the projects, selected the following developers: Amoco/Enron Solar Power Development; Cummins Power Generation; a combined effort by Kenetech Corporation, Photovoltaics International, and Solar Cells, Inc.; and a combined effort by Nevada Power, Entech, and Science Applications International Corporation.
Farmers and herdsmen in Gansu Province, China, will receive 800 solar electric home lighting systems from the nonprofit Solar Electric Lighting Fund (SELF) in Washington, DC, under contract with NREL. The project will build on the existing 1,000-house photovoltaic rural electrification program in the province, which was initiated by SELF in 1993. It is part of a larger protocol agreement signed in 1995 between the U.S. Department of Energy and the Chinese State Council on Science and Technology, to provide cooperation on a variety of renewable energy efforts. NREL and the Chinese government will share hardware and project management costs.

Arizona's 25-percent solar tax credit entered its second year, with no indication of price increases for solar water heaters (as were seen when Federal and State credits were in effect), according to the Arizona Department of Commerce. The State credits apply to 
the first $\$ 4,000$ spent for purchases of domestic solar hot water systems and solar daylighting. The State also has a sales tax exemption for purchases of solar goods.

At the Florida Solar Energy Center (FSEC) in Cocoa, FL, a year-long trial was started for a residential photovoltaic-powered water heater. The system, built by the National Institute of Standards and Technology in Gaithersburg, MD, uses computer technology to maximize the conversion of sunlight to electricity. Transfer of the system from NIST laboratories to the FSEC solar experimental station for field tests represented the latest advance for what NIST believes is a system with the potential to replace solar thermal water heating systems. Future field tests of the technology are expected to be held at the Kadena Air Force Base in Okinawa,
Japan, and at a site selected by the Tennessee Valley Authority.

Also in 1996, ECO and Uni Solar unveiled two new roofing products that will be commercially produced. The solar shingle for residential rooftops and a solar metal battenseam product for commercial rooftops can be integrated into traditional roofs without additional supporting structures and can be installed by commercial roofing companies. Uni Solar also announced the achievement of stable cell efficiency of 11.8 percent for its thin-film amorphous silicon alloy multiproduction modules, surpassing its earlier world record of 11.1 percent. The new stabilized module efficiency is expected to be 9 percent (for 4- to 8-foot square panels), eventually improving to about 10 percent. 
Section III

\section{Topical Issues}





\section{The Role of Electric Utilities in the Photovoltaics Industry}

\section{Introduction}

As the costs of photovoltaic (PV) modules have declined toward $\$ 3.50$ per watt ${ }^{120}$ and system costs toward $\$ 7.00$ per watt, many utilities have taken a renewed look at PV systems for grid-interactive applications. Utility and nongovernment organization (NGO) partnerships, such as PVUSA (Photovoltaics for UtilityScale Applications) and UPVG (Utility Photovoltaic Group), have been developed and expanded to demonstrate system performance and reliability, to lower costs, and to identify cost-effective applications. Currently, dozens of utilities are demonstrating PV systems at hundreds of sites across the country. Typical demonstrations include large-scale substation support, ${ }^{121}$ residential and commercial rooftop installations, and power quality correction. ${ }^{122}$

The Sacramento Municipal Utility District (SMUD) is the industry leader in many areas of grid-interactive PV development. SMUD sponsors the PV Pioneers program for small-scale residential rooftop applications. SMUD also recently took over from Pacific Gas \& Electric (PG\&E) as the leader of the PVUSA program. SMUD hosts an important substation support demonstration at its Hedge substation, and PG\&E hosts a similar demonstration at its Kerman substation. These demonstrations place PV technology in one of its highest valued gridinteractive applications. The benefits of substation support include such nontraditional benefits as local reliability enhancements, real and reactive energy loss savings, deferral of transformer replacement and maintenance, transmission capacity deferral, and power plant dispatch savings.

SMUD believes that domestic PV production and utility installation levels in the range of 50 to 100 megawatts per year are necessary for "sustained orderly development." SMUD expectations are that in 5 years sustained orderly development could lead to PV price declines sufficient to make the technology economically competitive with conventional generating sources. This development could include such programs as substation support and residential or commercial rooftop applications. SMUD currently projects that delivered power costs can be reduced from more than 20 cents per kilowatthour in 1996 to 6 cents per kilowatthour in 2001 with sustained orderly development. The experience utilities across the country are now obtaining in areas such as reliability, maintainability, and systems interactions would then have significant commercial relevance. Continued NGO partnerships are considered a key to this development.

\section{Utility Programs}

The utility industry, in collaboration with the U.S. Department of Energy (DOE), the Electric Power Research Institute (EPRI), and others, has established three major PV programs: Photovoltaics for Utility-Scale Applications (PVUSA), the Utility Photovoltaic Group (UPVG), and Photovoltaics for Utilities (PV4U). Each program is discussed below. In addition, the two utility substation support demonstrations, SMUD's Hedge substation and PG\&E's Kerman substation, are discussed. Other DOE and utility initiatives are also described.

\section{PVUSA}

\section{History and Objectives}

PVUSA was established in 1987 as a cooperative research effort by a dozen electric utilities, EPRI, and Federal and State government agencies, with the following objectives:

- Evaluate the performance, reliability, and cost of promising PV modules and balance-of-system components side-by-side at a single location

\footnotetext{
The author of this chapter is Peter Holihan, Renewable Industry Specialist, Energy Information Administration

${ }^{120}$ In this chapter, photovoltaic capacities given in watts refer to "peak watts."

${ }^{121}$ For large-scale substation support, a PV installation is used to supply power directly to a substation, in order to lessen the load on a generating station.

${ }^{122}$ Power quality correction operations make PV-generated power consistent with conventional transmission and distribution power requirements.
} 
- Assess PV system operation and maintenance (O\&M) costs in a utility setting

- Compare PV technologies in diverse geographic areas

- Offer U.S. utilities hands-on experience in designing, procuring, and operating PV systems

- Document and disseminate knowledge gained from the project.

The key commercial-scale, utility-sited PV system in the PVUSA program is at PG\&E's Kerman substation. An additional nine systems at utilities, including one of the five systems at SMUD's Hedge substation, are also part of the program. As of the end of 1995, 19 PV arrays were being tested. The following discussion, excerpted from the 1995 PVUSA Progress Report, ${ }^{123}$ summarizes the status of the PVUSA program.
PVUSA consists of two types of demonstrations: (1) emerging module technologies (EMTs), which are stateof-the-art technologies in 20-kilowatt (nameplate) arrays located at Davis, California; and (2) utility systems, which represent more mature PV technologies in turnkey systems ranging from 200 to 500 kilowatts (nameplate). Table 21 lists the PVUSA Davis EMT systems, Table 22 lists the PVUSA Davis and Kerman utility systems, and Table 23 lists PVUSA host utility systems. Each table also shows 1994 and 1995 performance using PVUSA's performance index. The index, which is similar to a capacity factor, includes adjustments for irradiance, temperature, degradation, soiling, and balance-ofsystem performance. The performance indices for 1995 include a 5-percent increase in the delivered efficiency power conditioning unit (PCU) ${ }^{124}$ low-load loss adjustment. This makes the 1995 results 5 percent higher than the 1994 results, all else being equal. The results

Table 21. PVUSA Emerging Module Technology Systems at Davis, California

\begin{tabular}{|c|c|c|c|c|c|c|}
\hline \multirow{2}{*}{$\begin{array}{l}\text { Completion } \\
\text { Date }\end{array}$} & \multirow[b]{2}{*}{ Supplier } & \multirow[b]{2}{*}{ Module Technology } & \multirow{2}{*}{$\begin{array}{l}\text { Direct Current } \\
\text { System } \\
\text { Efficiency } \\
\text { (Percent) }\end{array}$} & \multirow{2}{*}{$\begin{array}{c}\text { Direct Current } \\
\text { Power } \\
\text { (Kilowatts) }\end{array}$} & \multicolumn{2}{|c|}{$\begin{array}{c}\text { Performance } \\
\text { Index }\end{array}$} \\
\hline & & & & & 1994 & 1995 \\
\hline $01 / 89$ & Siemens Solar (ARCO) & Microgridded single-crystal silicon & 11.1 & 18.7 & 88 & 92 \\
\hline $06 / 89$ & Sovonics & Tandem-junction amorphous silicon & 3.5 & 17.3 & 88 & 91 \\
\hline $12 / 89$ & Utility Power Group & Tandem-junction amorphous silicon & 3.3 & 15.7 & 95 & 91 \\
\hline $10 / 90$ & Solarex & Bifacial polycrystalline silicon & 8.6 & 15.7 & 90 & 83 \\
\hline $03 / 91$ & ENTECH & $\begin{array}{l}22 x \text { linear concentrator, } \\
\text { crystalline silicon }\end{array}$ & 11.3 & 16.5 & 67 & 75 \\
\hline $11 / 94$ & AstroPower & $\begin{array}{l}\text { Thin-film polycrystalline silicon } \\
\text { on ceramic }\end{array}$ & 5.9 & 17.1 & 78 & 94 \\
\hline $12 / 95$ & Solar Cells & Cadmium telluride & 6.3 & 12.0 & NI & 99 \\
\hline $12 / 95$ & Amonix & $\begin{array}{l}260 \times \text { point-focus concentrator, } \\
\text { crystalline silicon }\end{array}$ & TBD & $a_{19.0}$ & NI & NR \\
\hline
\end{tabular}

asupplier's estimate.

$\mathrm{NI}=$ not installed. $\mathrm{NR}=$ not recorded. $\mathrm{TBD}=$ to be determined.

Notes: Efficiency and power were calculated at the time of initial acceptance, based on PVUSA test conditions and total module area. Test conditions were defined as 1,000 watts per square meter plane-of-array incidence, $20^{\circ} \mathrm{C}$ ambient temperature, and 1 mile per second wind speed. For concentrators, a direct normal irradiance of 850 watts per square meter was used. Direct current efficiency is reported because the emphasis is on comparing module performance. Start dates are staggered; therefore, some performance indexes are part-year.

Source: Pacific Gas \& Electric Co., 1995 PVUSA Progress Report, DOE/AL/82993-28, prepared for the U.S. Department of Energy under Cooperative Agreement DE-FC04-92-AL82993 (March 1996), pp. 1-5.

\footnotetext{
${ }^{123}$ Pacific Gas \& Electric Co., 1995 PVUSA Progress Report, DOE/AL/82993-28, prepared for the U.S. Department of Energy under Cooperative Agreement DE-FC04-92-AL82993 (March 1996).

${ }^{124}$ PCUs are used to convert direct current (d.c.) to alternating current (a.c.).
} 
show both a significant number of solidly performing systems and several systems with low capacity factors, including Kerman in 1995 and Hedge in 1994.

\section{Performance of PVUSA Systems}

Performance highlights of PVUSA systems since 1989 can be summarized as follows:

- Cumulative output from 1989 through 1995 totaled 7.1 gigawatthours, of which 2.3 gigawatthours represented 1995 output (from systems shown in Tables 21, 22, and 23).

- System efficiencies ranged from about 3 percent for amorphous silicon modules to between 7 and 10 percent for single-crystal silicon modules.

- Only 4 of the 18 systems rated by PVUSA met or exceeded the supplier's efficiency estimates.

- Efficiencies of fielded arrays and systems appear to be degrading by an average of 2 percent per year.

- Annual capacity factors ranged from 7 to 21 percent. Monthly capacity factors for several systems exceeded 30 percent during the summer. Peak period capacity factors for several systems in PG\&E's service territory were in the range of 50 to 66 percent.
- Panelized and factory-wired modules reduced field labor and costs. Integration of the module or panel supports into the array structure also reduced costs.

- Module reliability has been very good. The majority of failures at both Davis and Kerman were related to wiring and connections, tracking system misoperation, and power conditioning.

\section{UPVG}

UPVG was established in 1992 with support from EPRI, the American Public Power Association (APPA), the Edison Electric Institute (EEI), and the National Rural Electric Cooperative Association (NRECA). As of May 1996, 76 utilities were members of the group. Its objectives are to accelerate cost-effective PV applications, aggregate market demand, and demonstrate near-term uses. Among other projects, UPVG has published a sixvolume analysis of PV status, opportunities, and markets and has developed a comprehensive action plan for stimulating demand in those markets.

With an estimated one-third financial support from DOE, UPVG sponsors TEAM-UP (Technology Experience to Accelerate Markets in Utility Photovoltaics). TEAM-UP is a $\$ 500$ million, 6-year initiative to accelerate the demonstration of 50 megawatts of on-grid and

Table 22. PVUSA Utility Systems at Davis and Kerman, California

\begin{tabular}{|c|c|c|c|c|c|c|}
\hline \multirow[b]{2}{*}{$\begin{array}{c}\text { Completion } \\
\text { Date }\end{array}$} & \multirow[b]{2}{*}{ Supplier } & \multirow[b]{2}{*}{ System Technology } & \multirow{2}{*}{$\begin{array}{l}\text { Alternating } \\
\text { Current } \\
\text { System } \\
\text { Efficiency } \\
\text { (Percent) }\end{array}$} & \multirow{2}{*}{$\begin{array}{l}\text { Alternating } \\
\text { Current } \\
\text { Power } \\
\text { (Kilowatts) }\end{array}$} & \multicolumn{2}{|c|}{$\begin{array}{l}\text { Performance } \\
\text { Index }\end{array}$} \\
\hline & & & & & 1994 & 1995 \\
\hline \multicolumn{7}{|c|}{ Davis Systems } \\
\hline $9 / 92$ & Advanced PV Systems & $\begin{array}{l}\text { Amorphous silicon, fixed tilt, } \\
\text { APS PCU }\end{array}$ & 4.2 & 479 & 83 & 73 \\
\hline $6 / 93$ & Integrated Power Corp. & $\begin{array}{l}\text { Ribbon silicon (MSEC EFG), } \\
\text { one-axis active-tracking, KW! PCU }\end{array}$ & 8.0 & 196 & 31 & 40 \\
\hline $5 / 94$ & Siemens Solar & $\begin{array}{l}\text { Single-crystal silicon, one-axis } \\
\text { passive-tracking, Bluepoint PCU }\end{array}$ & ${ }^{\mathrm{a}} 7.9$ & ${ }^{a} 67$ & 60 & 57 \\
\hline \multicolumn{7}{|c|}{ Kerman System } \\
\hline $6 / 93$ & Siemens Solar & $\begin{array}{l}\text { Single-crystal silicon, one-axis } \\
\text { passive-tracking, Omnion PCU }\end{array}$ & 9.8 & 498 & 85 & 51 \\
\hline
\end{tabular}

${ }^{a}$ Based on 50 percent of the array.

Notes: Efficiency and power were calculated at the time of initial acceptance, based on PVUSA test conditions and total system area. Test conditions were defined as 1,000 watts per square meter plane-of-array incidence, $20^{\circ} \mathrm{C}$ ambient temperature, and 1 mile per second wind speed. Alternating current efficiency is reported because the emphasis is on comparing system performance. Power conditioning unit (PCU) efficiencies of 90 to 95 percent account for almost all the difference between alternating current and direct current efficiencies. Start dates are staggered; therefore, some performance indexes are part-year.

Source: Pacific Gas \& Electric Co., 1995 PVUSA Progress Report, DOE/AL/82993-28, prepared for the U.S. Department of Energy under Cooperative Agreement DE-FC04-92-AL82993 (March 1996), pp. 1-5. 
off-grid PV applications. Its first request for proposals (issued in December 1994 and accepted in 1995) resulted in cofunding of $\$ 32$ million of utility proposals and 5.6 megawatts of PV applications in more than 340 installations at 25 utilities in 12 States. Table 24 highlights the awards for grid-connected systems. In second-round awards, announced in May 1996, 11 teams representing almost 50 electric utilities were awarded $\$ 4.5$ million in Federal funds. These venture teams are expected to invest more than $\$ 16$ million to install more than 1,000 new PV systems in as many as 25 States.

\section{- PV4U}

PV4U is a loose confederation of State-level working groups that includes universities, PV manufacturers, State energy offices, and utilities. As of fall 1995, 15 States had PV4U working groups. Highlights of PV4U

Table 23. PVUSA Host Utility Systems

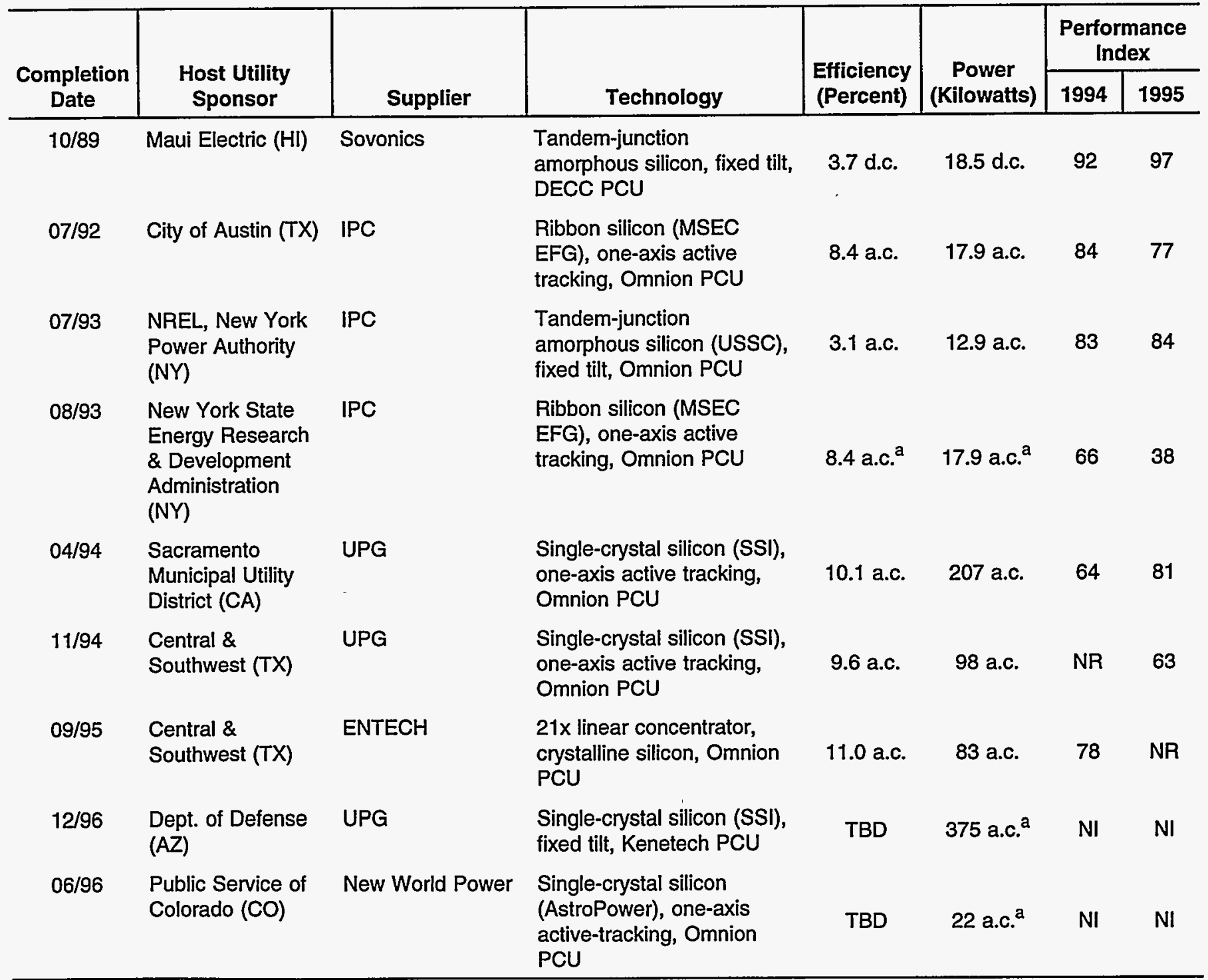

\footnotetext{
${ }^{\mathrm{a}}$ Estimate.
}

a.c. = alternating current. d.c. $=$ direct current. $\mathrm{NI}=$ not installed. $\mathrm{NR}=$ not recorded. $\mathrm{TBD}=$ to be determined.

Notes: Efficiency and power were calculated at the time of initial acceptance, based on PVUSA test conditions and total area. Test conditions were defined as 1,000 watts per square meter plane-of-array incidence, $20^{\circ} \mathrm{C}$ ambient temperature, and 1 mile per second wind speed. For concentrators, a direct normal irradiance of $\mathbf{8 5 0}$ watts per square meter was used. Generally, emerging module technologies are rated on array d.c. output and utility systems are rated on a.c. output (determined by contract). Start dates are staggered; therefore, some performance indexes are part-year.

Source: Pacific Gas \& Electric Co., 1995 PVUSA Progress Report, DOE/AL/82993-28, prepared for the U.S. Department of Energy under Cooperative Agreement DE-FC04-92-AL82993 (March 1996), pp. 1-6. 
activities and PV-related events in 1995 are summarized below. ${ }^{125}$

Arizona. Arizona Public Service Company (APS) is installing the 25-kilowatt PV/hybrid system at Carol Spring Mountain, testing four systems for its remote PV leasing program, developing a 50-kilowatt PV covered parking project, a 17-kilowatt home "green pricing" project, a 125-kilowatt tracking PV system to provide transmission and distribution support, and a 36-kilowatt high-concentration PV system. APS has a net metering rate schedule (EPR-3) and a remote PV leasing rate schedule (Solar-1). The Salt River Project is testing a PV-powered heat pump and is involved in a Solarex advanced amorphous-silicon PV project. Tucson Electric Power Company has installed a 500-watt grid-tied system at a local school district and has a grant to install a 5-kilowatt PV system at the University of Arizona Agricultural Station. Arizona Electric Power Cooperative, Inc., plans to install an 18-kilowatt PV system to serve one of its buildings.
California. SMUD is leading a nine-utility project to install PV systems at more than 200 residential, commercial, and industrial sites. Other California utilities in the project are Southern California Edison, the Northern California Power Agency, and the City of Anaheim. The second California project is a 5-megawatt centralstation PV power plant in Imperial County. The total cost of the proposed Amoco/ENRON Solar Power Development joint venture is less than $\$ 2$ per watt installed. The power will be sold to San Diego Gas \& Electric.

Colorado. The UPVG TEAM-UP project awarded to Empire Electric and its partners funding for a 126-kilowatt PV system at the end of an unreliable transmission line in Mesa Verde National Park.

Delaware. Delmarva Power has installed a 15-kilowatt, grid-connected, rooftop PV system at its northern headquarters. The president of AstroPower has installed a 4-kilowatt rooftop PV system on his home in Newark,

Table 24. Utility Photovoltaic Group (UPVG) TEAM-UP Ventures, 1995

\begin{tabular}{|c|c|c|c|c|}
\hline Lead Utility(s) & Key Objectives & $\begin{array}{c}\text { Total Cost } \\
\text { (Million } \\
\text { Dollars) }\end{array}$ & $\begin{array}{l}\text { TEAM-UP } \\
\text { Funding } \\
\text { (Millions } \\
\text { Dollars) }\end{array}$ & $\begin{array}{l}\text { Alternating } \\
\text { Current } \\
\text { Power } \\
\text { (Kilowatts) }\end{array}$ \\
\hline Niagara Mohawk & Power quality correction & 2.40 & 0.30 & 100 \\
\hline Hawaii Electric & $\begin{array}{l}\text { Evaluate attachment of modules to roofing } \\
\text { insulation }\end{array}$ & 0.20 & 0.06 & 15 \\
\hline $\begin{array}{l}\text { Sacramento Utility District } \\
\text { and eight other utilities }\end{array}$ & $\begin{array}{l}\text { Rooftop, building-integrated, and transmission } \\
\text { and distribution support }\end{array}$ & 10.90 & 1.70 & 1,400 \\
\hline Arizona Public Service & $\begin{array}{l}\text { Standardize rooftop systems for covered } \\
\text { parking garages }\end{array}$ & $a_{5.3}$ & ${ }^{\mathrm{a}} 0.9$ & 50 \\
\hline Arizona Public Service & $\begin{array}{l}\text { Tracking systems for transmission and } \\
\text { distribution support }\end{array}$ & $a_{5.3}$ & ${ }^{\mathrm{a}} 0.9$ & 125 \\
\hline $\begin{array}{l}\text { Arizona Public Service, } \\
\text { Nevada Power, Central \& Southwest }\end{array}$ & High-concentration (230x) systems & $a_{5.3}$ & ${ }^{\mathrm{a}} 0.9$ & 72 \\
\hline Eight utilities & Validate green pricing programs & 3.10 & 1.40 & 350 \\
\hline Public Service of Colorado & Transmission and distribution support & 0.25 & 0.06 & 22 \\
\hline Northern States Power & $\begin{array}{l}\text { Dual-axis tracker, } 22 x \text { concentration in a cold } \\
\text { climate }\end{array}$ & 0.04 & 0.01 & 2 \\
\hline UtilCorp United, Nevada Power & Power quality & 0.34 & 0.16 & 40 \\
\hline Gainesville Regional Utility & Uninterruptible power supply, green pricing & 0.20 & 0.04 & 10 \\
\hline
\end{tabular}

${ }^{a}$ Denotes funding for all three Arizona Public Service Projects.

Source: "Utility Photovoltaic Group 1995 TEAM-UP Ventures," http:/www.paltech.com.ttc/upvg/pr_sep95.htm.

\footnotetext{
${ }^{125}$ Interstate Renewable Energy Council, "Reports from the PV4U State Working Groups," PV4U Connections, No. 3 (Fall 1995), web site www.eren.doe.gov/irec.
} 
Delaware, as a prototype. Delmarva Power, the Delaware Electric Cooperative, the State government, and the Delaware Nature Society are installing a 1.5-kilowatt PV system on a State-owned building.

Hawaii. Hawaiian Electric proposes to install a gridconnected, 15-kilowatt commercial rooftop PV application in Kailua-Kona, which is located on the island of Hawaii.

Idaho. The Idaho Power Company (IPCo) is experiencing a flurry of activity in its PV tariff program. IPCo installed twice as many PV systems in the summer of 1995 as the total number of systems installed during the first 2 years of the program.

Maryland. Some utility projects under review include highway sign lighting, PV water pumping, rooftop PV, and a remote and relocatable PV service in a box for small 120-volt plug loads.

Massachusetts. Utilities continue to install and monitor residential, commercial, and street-lighting installations. Planned installations include a 2.5-kilowatt grid-connected system in Cambridge and a 2-kilowatt system in a State park. An additional 5 kilowatts of PV-assisted lighting will be installed by the Taunton Municipal Lighting Plant.

New York. Installation of a PV system at the Bennington Historic Site was expected in 1996.

Wisconsin. Wisconsin has 11 grid-connected PV systems that have been monitored by utilities for up to 6 years. In addition, about 20 small, grid-connected, nonutility PV systems have also been installed.

\section{The SMUD Experience- Recent and Projected Cost Trends}

The Sacramento Municipal Utility District (SMUD) is leading the utility industry in attempting to advance the development of low-cost, grid-connected PV applications. Two programs are of particular note: PV Pioneers and the Hedge substation.

\section{PV Pioneers}

In 1994, SMUD established a voluntary program called PV Pioneers through which the utility's participating customers permit SMUD to install 400 square feet of solar panels on the roofs of their homes. PV Pioneers agree to pay a 10 -percent premium (approximately $\$ 4$ per month) over their electric bill for 10 years. More than 700 homeowners volunteered for the first 100 available installations.

The most recent bidding for the PV Pioneers program was completed in the spring of 1996. SMUD received bids for modules in the range of $\$ 3.50$ per watt (a.c.) and turnkey costs in the range of $\$ 5.50$ per watt. Including program and other costs, SMUD estimates the modules to cost about $\$ 6.50$ to $\$ 7.00$ per watt. These costs translate into electricity costs of about 16.5 to 18 cents per kilowatthour. In comparison, costs for 1994 and 1993 for rooftop installations were about $\$ 7.13$ per watt ( 20 cents per kilowatthour) and $\$ 8.78$ per watt ( 23 cents per kilowatthour), respectively. ${ }^{126}$

For 2001, SMUD projects system costs of about $\$ 2.82$ per watt and an electricity cost of about 7.4 cents per kilowatthour. Excluding costs for running the program, SMUD projects costs at 6.3 cents per kilowatthour by 2001. On a component-by-component basis, SMUD's estimates for cost reductions from 1996 to and 2001 are as follows (all in dollars per peak watt, a.c.):

- Modules- $\$ 3.80$ to $\$ 1.74$

- Power Conditioning- $\$ 0.66$ to $\$ 0.23$

- Non-inverter balance of system and installation- $\$ 0.60$ to $\$ 0.40$

- Panelization and engineering design and insurance- $\$ 0.40$ to $\$ 0.10$.

The valuation of the residential PV Pioneers systems is different from that of a utility-owned system or a distribution support system. Effective January 1, 1996, all California utilities are required to provide net metering of residential PV systems up to 10 kilowatts. Net metering means that the PV system is valued (by the customer) at the residential retail price of electricity, not the wholesale avoided cost of electricity. The retail price of electricity is typically several times greater than the avoided cost of electricity. Net metering is a potentially crucial method of obtaining customer acceptance. So long as the installed PV capacity billed on a net basis is small, the effective subsidy provided by the utility is not likely to affect utility system economics. The California law limits net metering for each utility to 0.1 percent of the utility's 1996 peak demand. For the California utilities as a group, this amounts to slightly. more than 50 megawatts. While 50 megawatts is insignificant for the utilities as a group, it is significant in relation to the installed PV capacity base.

\footnotetext{
${ }^{126}$ D.E. Osborn and D.E. Collier, Sacramento Municipal Utility District, "Utility Grid-Connected Photovoltaic Distributed Power Systems," in American Solar Energy Society (ASES) 96 (Asheville, NC, April 1996).
} 


\section{Hedge Substation}

The Hedge substation plant is a series of PV installations at the Hedge substation for transmission and distribution support. SMUD started construction of the first PV system at Hedge in 1993 and completed installation of a 210-kilowatt ground-mounted, single-axis tracking system in 1994. This first Hedge system (which is part of the PVUSA program) had a turnkey cost of $\$ 7.70$ per watt. Including a 23-percent increase in performance of tracking versus fixed-tilt technology, the effective turnkey cost was $\$ 6.26$ per watt. Including SMUD's costs of $\$ 3.89$ per watt, the total system cost was $\$ 10.15$ per watt, or 32 cents per kilowatthour over 30 years.

In 1994, SMUD began the addition of three additional systems at Hedge with a total rating of 317 kilowatts. The three systems, completed in 1995, were each rated at just over 100 kilowatts. The two fixed-tilt systems had nominal costs of $\$ 6.68$ per watt and $\$ 7.35$ per watt. A third system, using a single-axis tracking system, had a nominal cost of $\$ 7.50$ per watt and an equivalent power factor (EPF) cost of $\$ 6.10$ per watt. In 1995, SMUD began construction of a 214-kilowatt (nominal), 263-kilowatt EPF tracking system. The system turnkey cost is $\$ 7.00$ per watt (nominal) or $\$ 5.71$ per watt $(\mathrm{EPF}){ }^{127}$

\section{SMUD Cost Trends}

Table 25 summarizes SMUD's PV cost improvement for 1993-95 for its substation and residential projects.
SMUD believes that with a sustained, widespread collaborative effort, PV system prices could drop below $\$ 3$ per watt by 2000 . SMUD believes this would occur if utility orders and production increases moved quickly from a few megawatts a year to between 50 and 100 megawatts per year by the end of the 1990s. SMUD characterizes this scenario, in which PV system prices are expected to drop into the range of competitiveness with gas-fired generation, as "sustained orderly development."

\section{PG\&E-The Kerman Substation PV Plant}

The Kerman PV plant on the PG\&E system is the first and largest plant designed and built to measure the benefits of grid-support photovoltaics. The plant, designed at 500 kilowatts a.c. and rated by PVUSA at 498 kilowatts a.c., was completed in 1993. It is connected to a semi-rural 12-kilovolt (kilovolt-amperes) distribution feeder about 8 circuit-miles downstream from PG\&E's Kerman substation. A 10.5-megavolt (megavolt-amperes) transformer bank at the substation maintains feeder voltage and supplies current to customers.

\section{Traditional Benefits and Costs}

Traditional benefits can be measured in terms of energy and capacity. Traditional costs (excluding capital costs) are for operations and maintenance.

Energy Value. During the 1993-94 12-month evaluation period, the Kerman PV plant (498 kilowatts capacity)

Table 25. Sacramento Municipal Utility District (SMUD) Photovoltaic System Cost Improvement, 1993-1995

\begin{tabular}{|c|c|c|c|c|c|}
\hline \multirow[b]{2}{*}{ Year } & \multirow[b]{2}{*}{ Project } & \multicolumn{3}{|c|}{ Capacity Costs (Dollars per Watt) } & \multirow{2}{*}{$\begin{array}{l}\text { 30-Year Generation Costs } \\
\text { (Cents per Kilowatthour) }^{c}\end{array}$} \\
\hline & & Turnkey $^{a}$ & SMUD & Total & \\
\hline 1993 & Substation $^{\mathrm{d}}$ & 6.26 & 3.89 & 10.15 & 32 \\
\hline 1994 & Substation ${ }^{\mathrm{e}}$ & 6.68 & 1.07 & 7.75 & 21 \\
\hline 1994 & Substation & 6.10 & 0.87 & 6.97 & 19 \\
\hline 1995 & Substation $^{d}$ & 5.71 & 0.91 & 6.62 & 18 \\
\hline 1993 & Residential $^{e}$ & 7.70 & 1.08 & 8.78 & 23 \\
\hline 1994 & Residential $^{e}$ & 6.23 & 0.90 & 7.13 & 20 \\
\hline 1995 & Residential $^{d}$ & 5.98 & 0.89 & 6.87 & 18 \\
\hline
\end{tabular}

Turnkey contract cost up to utility interconnection, without tax, bonding, or utility add-on costs.

Includes interconnections, metering, site preparation, labor, administration, overheads, tax, bonding, AFUDC, and other costs.

${ }^{c}$ Preliminary estimate, including operation and maintenance, excluding DOE cost-sharing.

dSingle-axis tracking system, includes Energy Production Credit factor of 1.23 compared to fixed tilt.

${ }^{\theta}$ Fixed, non-tracking (EPF $=1.0$ ).

Source: D.E. Osborn and D.E. Collier, "Utility Grid-Connected Photovoltaic Distributed Power Systems," presented to the American Solar Energy Society (ASES) 1996 Conference (Asheville, NC, April 1996).

${ }^{127}$ D.E. Osborn and D.E. Collier, “Utility Grid-Connected Photovoltaic Distributed Power Systems.” 
generated 1,080 megawatthours. ${ }^{128}$ This output corresponds to a capacity factor of about 25 percent. The value of the output depends on PG\&E's avoided cost of energy, which varies from month to month. Since 1992, it has ranged from an annual average of 1.84 to 2.96 cents per kilowatthour ( $\$ 18.40$ to $\$ 29.60$ per megawatthour). During 1995, it averaged approximately $\$ 18.40$ per megawatthour. ${ }^{129}$ Ordinarily, the avoided cost of energy is highest during the summer peaking season, when PV output is also highest. For the past few years, however, the value of energy during the summer peaking season in California has been historically low, due to surplus gas transmission capacity and low natural gas prices. The historically low value is likely to continue for some time with little or no increase. Thus, this value can be considered a constant-dollar lower bound.

During the summer of 1996, the price of nonfirm onpeak ( 6 a.m. to 10 p.m.) energy at the California-Oregon and California-Nevada borders was in the range of $\$ 15$ to $\$ 20$ per megawatthour. This is consistent with PG\&E's avoided costs for most of the 1990s. Firm, on-peak energy was roughly $\$ 4$ per megawatthour more. $^{130}$ At $\$ 20$ per megawatthour, the value of the Kerman output from July 1993 through June 1994 (1,080 megawatthours) would have been about $\$ 21,600$, or $\$ 43$ per kilowatt per year. ${ }^{131}$ At $\$ 25$ per megawatthour, the value of the Kerman output for that period would have been about $\$ 27,300$, or $\$ 55$ per kilowatt per year.

During the mid- to late 1980s, the long-rin avoided cost for on-peak energy was commonly expected to be in the range of $\$ 60$ per megawatthour for most of the country. At that value, the energy from Kerman during the 1993-94 period would have been worth about $\$ 130$ per kilowatt per year. Although an avoided cost of $\$ 60$ per megawatthour appears unlikely in the near future, it may be a reasonable upper bound over a long period of time. This suggests a current, constant-dollar lowerbound value of Kerman energy (assuming a capacity factor of about 25 percent) of roughly $\$ 50$ per kilowatt per year and a possible, though unlikely, constantdollar upper bound of roughly $\$ 130$ per kilowatt per year.

PVUSA estimates average system degradation at roughly 2 percent per year across all systems. For system economics based on a 30-year lifetime, 2-percent annual degradation is highly significant. It implies that output in the thirtieth year would only be about 55 percent of that in the first year. Degradation at this rate exerts continual downward pressure on system value and diminishes any real increases in value due to higher avoided costs.

Capacity Value. PG\&E currently has no need for additional capacity. In fact, PG\&E is under regulatory advisement to plan for no additional capacity (at least not nonrenewable capacity). Thus, the value of the capacity provided by the Kerman PV plant to PG\&E is effectively zero. The off-system value of the Kerman plant (i.e., the surplus capacity it frees for off-system sale) depends on the need for capacity elsewhere in the region. In general, capacity value is established by the equivalent load-carrying capability of a plant at the value of the least-cost generic capacity, i.e., a combustion turbine. Combustion turbine capacity is typically available anywhere in the country at about $\$ 40$ to $\$ 50$ per kilowatt per year. In energy-equivalent units, this capacity value translates to roughly $\$ 4$ per megawatthour. This translation is the reason the difference in price between firm and nonfirm on-peak energy at the California-Oregon border is roughly $\$ 4$ per megawatthour. This value is likely to remain constant for the foreseeable future.

At Kerman's estimated 77 percent equivalent-load carrying capability ${ }^{132}$ the value of displacing combustion turbine capacity is in the range of $\$ 30$ to $\$ 40$ per kilowatt per year, or about $\$ 3$ per megawatthour. The extent to which PG\&E can capture the value of Kerman capacity by selling other capacity off-system varies from time to time. Because of the current surplus of capacity in the western United States, the value of off-system capacity sales made possible by the existence of Kerman is low. If it is assumed that PG\&E can capture the value of Kerman capacity via off-system sales of surplus capacity 50 percent of the time, Kerman's measured capacity value of $\$ 30$ to $\$ 40$ per kilowatt per year under a full capacity credit would be worth $\$ 15$ to $\$ 20$ per kilowatt per year to PG\&E.

Operation and Maintenance (O\&M) Costs. From June 1993 through 1995, the Kerman system had a cumulative O\&M cost of $\$ 15$ per megawatthour. Assuming

${ }^{128}$ H.J. Wenger, T.E. Hoff, and B.K. Farmer, "Measuring the Value of Distributed Photovoltaic Generation: Final Results of the Kerman Grid-Support Project," presented to the First World Conference on Photovoltaic Energy Conversion (Waikoloa, HI, December 1994).

${ }^{129}$ Calpine Corporation, U.S. Securities and Exchange Commission Form S-4 Registration Statement (Washington, DC, 1995).

130"DJ Electricity Prices," The Wall Street Journal Ouly and August 1996).

${ }^{131}$ Costs were calculated as follows: $\$ 20$ per megawatthour $\times 1,080$ megawatthour per year $=\$ 21,600$ per year; $\$ 21,600$ per year $/ 498$ kilowatts $=\$ 43$ per kilowatt per year. The additional value of Kerman output at distribution voltage at the substation (versus transmission voltage at the Oregon border) is captured in the section on nontraditional benefits.

${ }^{132}$ H.J. Wenger, T.E. Hoff, and B.K. Farmer, "Measuring the Value of Distributed Photovoltaic Generation: Final Results of the Kerman Grid-Support Project." 
long-range costs at this level and performance at a 25percent capacity factor, $\$ 15$ per megawatthour is about equal to $\$ 8$ per kilowatt per year. In general, module reliability has been good. The majority of failures were related to wiring and connections, tracking system misoperation, and power conditioning.

During 1995, maintenance costs at Kerman averaged $\$ 32$ per megawatthour, consisting of roughly $\$ 10$ per megawatthour for preventive maintenance and $\$ 22$ per megawatthour for failure-related maintenance. O\&M costs at Kerman were consistent with 1995 O\&M costs for the three other utility system installations in the PVUSA program (all at Davis, California) of $\$ 27$ to $\$ 57$ per megawatthour (weighted average of $\$ 33$ per megawatthour). ${ }^{133}$ Expectations are that long-run O\&M costs will trend back downward toward $\$ 15$ per megawatthour from the unusually high 1995 values.

Total Traditional Benefits. Taken together, the traditional benefits from the Kerman PV system range from a constant-dollar low of about $\$ 65$ per kilowatt per year to a constant-dollar high of roughly $\$ 170$ per kilowatt per year. Assuming the continued surplus of natural gas in the West region, the excess of generating capacity, and the likelihood of 2 percent per year degradation in module efficiency, the value of Kerman will tend toward the low end of the range for the foreseeable future.

In 1995, the Kerman PV plant generated 572 megawatthours of electricity, or about a 13-percent capacity factor. System outages were disproportionately concentrated in the summer months. At a 13-percent capacity factor (annual average), the traditional benefits from the PV station would be reduced by about half from those stated above, as the long-term capacity factor has been 25 percent. Poor summer performance means an even greater reduction in value. Had capacity value represented a larger share of the station valuation, the poor 1995 performance would have reduced traditional benefits even more.

Evidence from the other PVUSA utility systems (Table 22) suggests that Kerman's 1995 performance was below par for the group. Although PVUSA did not calculate performance indexes prior to 1994, the total output from the utility systems installed before 1994 is consistent with performance indexes at about the 60 percent level for the Integrated Power Corporation's system and the 70 percent level for the APS system. Ironically, Kerman's best performance index would have been its part-year 1993 index, had that value been calculated. Overall, Kerman's poor 1995 performance should not be considered representative of its future performance. Accordingly, the estimated long-run, constant-dollar valuation for Kerman on a traditional evaluation basis is in the range of $\$ 55$ per kilowatt per year to $\$ 160$ per kilowatt per year.

\section{Nontraditional Benefits}

Nontraditional benefits consist of externalities from reduced fossil fuel use, local reliability enhancements, real and reactive energy loss savings, deferral of transformer replacement and load-tap-changer maintenance, transmission capacity deferral, and power plant dispatch savings. Table 26 summarizes the estimated value of these benefits. The table shows nontraditional benefits ranging from a low of $\$ 138$ per kilowatt per year to a high of $\$ 214$ per kilowatt per year.

Within the category of nontraditional benefits, it is useful to distinguish those benefits that can be captured by the utility and those benefits that may have value to society but cannot be captured by the utility. In Table 26, the row labeled "Externalities" indicates that about 95 percent of the emissions savings, valued at $\$ 31$ to $\$ 34$ per kilowatt per year, arise from reduced $\mathrm{CO}_{2}$ and $\mathrm{NO}_{x}$ emissions. The $\mathrm{SO}_{2}$ offset accounts for only 4 percent of the emissions value. Offsets of particulates account for 1 percent.

Currently, no market exists for offsets to $\mathrm{CO}_{2}$ and only limited regional markets exist for offsets to $\mathrm{NO}_{x}$ (unlike the national market for $\mathrm{SO}_{2}$ offsets). The development of a market for $\mathrm{NO}_{\mathrm{x}}$ offsets depends on how the U.S. Environmental Protection Agency implements the Clean Air Act Amendments of 1990. Thus, while it may be beneficial to society to reduce emissions of $\mathrm{CO}_{2}$ and $\mathrm{NO}_{\mathrm{x}}$ it is not necessarily the case that the utility can realize the $\mathrm{CO}_{2}$ or $\mathrm{NO}_{x}$ offset benefits. This inability to realize the value of emissions offsets is particularly true for $\mathrm{CO}_{2}$, which represents an estimated 39 percent of the emissions offset value. There is no legal, regulatory, or financial tradeoff of any type that relates to $\mathrm{CO}_{2}$ offsets.

The other benefits shown in Table 26 arise from improvements to the PG\&E system or its operations from the existence of a peaking generation source at distribution voltage near a high-stress substation. These benefits belong in all internal analyses of the value of the plant. Because of low energy costs, however, the current value from reduced transmission and distribution losses is perhaps only half the value shown in the table.

\footnotetext{
${ }^{133}$ Pacific Gas \& Electric Co., 1995 PVUSA Progress Report, pp. 4-12, 4-13, 11-5, and 11-6.
} 
Table 26. Kerman Photovoltaic Plant Nontraditional Benefits (1995 Dollars)

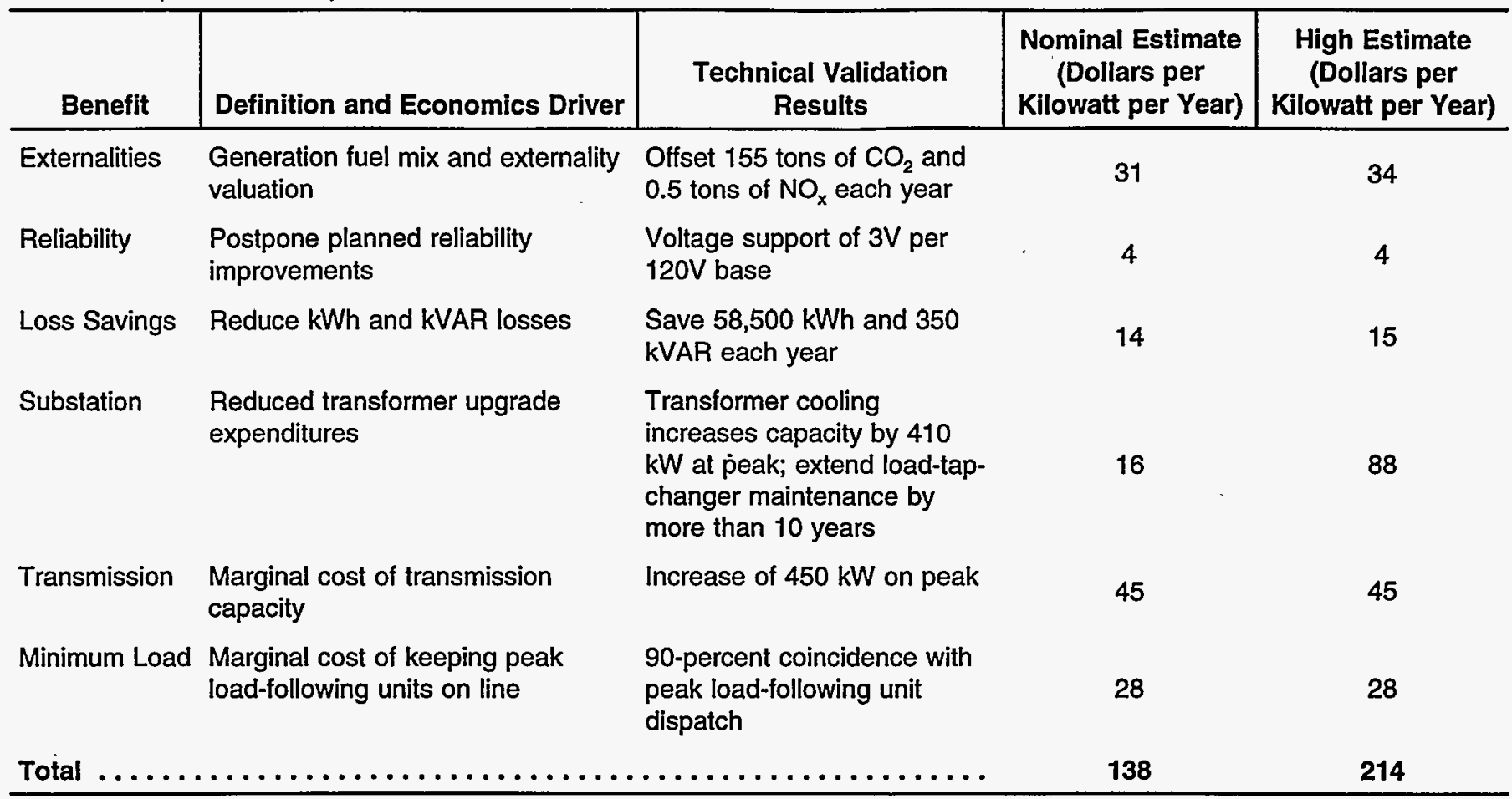

Source: H.J. Wenger, T.E. Hoff, and B.K. Farmer, "Measuring the Value of Distributed Photovoltaic Generation: Final Results of the Kerman Grid-Support Project," First World Conference on Photovoltaic Energy Conversion (Waikoloa, HI, December 1994).

\section{Combined Net Benefits}

Combining traditional and nontraditional benefits, net of O\&M costs, and adjusted for $\mathrm{CO}_{2}$ and energy loss benefits, generates a value for the Kerman PV installation roughly in the range of $\$ 180$ per kilowatt per year to $\$ 380$ per kilowatt per year, assuming a 25-percent capacity factor. This range almost certainly encompasses possible increases in natural gas prices and possible module degradation over time. Even ignoring the poor 1995 performance at Kerman, PV system valuations are considerably lower than had been expected when the plant was conceived. ${ }^{134}$ There are three reasons for this:

- Energy and capacity values are low due to low natural gas prices, surplus hydroelectric capacity, and a 1992 regulatory assumption that PG\&E does not need capacity for the foreseeable future.

- Local reliability enhancement value is low because a capacitor bank could be added to the Kerman circuit and provide the same operational benefits at a lower cost than had been previously estimated.
- Substation transformer value is low because it is relatively easy to switch load in the Kerman area.

\section{Breakeven Cost}

The breakeven capital cost of the Kerman PV system (including balance-of-system costs, installation, and allowance for funds used during construction) can be estimated from the valuation described above. Using utility costs of capital, and excluding tax credits, the breakeven capital cost is roughly 9 times the constantdollar valuation in net dollars per kilowatt per year. Since most PV costs are known and fixed at the time the plant is completed (i.e., there is no fuel cost and little likelihood of unusual escalation in O\&M costs), the estimated constant-dollar valuation is likely to be very close to the actual, future value.

The most conservative valuation and the only allowable one-traditional benefits only and a continuation of current avoided energy and capacity costs-generates a valuation of about $\$ 55$ per kilowatt per year or about $\$ 500$ per kilowatt. For traditional benefits but upper-

${ }^{134}$ H.J. Wenger, T.E. Hoff, and B.K. Farmer, "Measuring the Value of Distributed Photovoltaic Generation: Final Results of the Kerman Grid-Support Project." 
bound long-range avoided energy and capacity costs, the valuation is about $\$ 160$ per kilowatt per year, or about $\$ 1,450$ per kilowatt. The key difference between these two valuations is the difference between constantdollar avoided energy costs at roughly $\$ 20$ per megawatthour (current avoided energy costs) and roughly $\$ 60$ per megawatthour (long-run upper bound). Combining traditional and nontraditional benefits generates a range of roughly $\$ 180$ to $\$ 380$ per kilowatt per year, or roughly $\$ 1,700$ to $\$ 3,600$ per kilowatt.

For the Kerman installation, the turnkey cost was $\$ 8,900$ per kilowatt, ${ }^{135}$ and the total plant cost, including utility costs, was about $\$ 11,000$ per kilowatt. The cost of the Kerman system is thus about six times greater than the value of its current traditional and nontraditional benefits and about three times greater than an optimistic upper bound on long-run avoided costs for energy and capacity.

\section{Other Grid-connected Activities}

About half of the $\$ 87$ million fiscal year 1996 budget of DOE's Office of Energy Efficiency and Renewable Energy is allocated for participation in three collaborative programs: UPVG (described above), PVMat (PV manufacturing process research), and PV:BONUS (development of $P V$ products for integration into residential and commercial buildings). Of these, UPVG is the key program related to utility grid-interactive photovoltaics.

In late 1994, Enron (now Amoco/Enron) proposed a 1,016-megawatt solar park in Nevada that would include up to 175 megawatts of central station PV (later reduced to 100 megawatts). Amoco/Enron claims that it could produce power at a levelized cost of 5.5 cents per kilowatthour using nonconcentrating, advanced thin films. Amoco/Enron's solar park is in an early stage of consideration and cannot be evaluated for financial risk or investor requirements. The estimate of 5.5 cents per kilowatthour, however, is based on a cost of capital of 5 percent and assumes some type of taxexempt financing, such as industrial revenue bonds issued by Nevada. In January 1996, Amoco/Enron was notified that it was one of four finalists for a DOE power purchase contract. As of the middle of 1996, no further announcement had been made.

Amoco/Enron Solar Power Development is also proposing to build a $\$ 7$ million solar electric generation facility in Hawaii during 1997 with the aid of a \$1.14 million award from UPVG. The facility will use 4 megawatts of PV modules produced by a thin-film manufacturing process at a new Solarex factory that began construction in October 1995 near Williamsburg, Virginia. Hawaiian Electric is slated to purchase the solar-generated electricity.

In 1996, Detroit Edison dedicated the first customersupported, centralized PV generating facility in the United States. The system is supported in part by customers paying a supplemental "green rate" for renewable energy. A portion of the construction cost $(\$ 116,160)$ was supplied by The DOE/UPVG consortium. The 28.4-kilowatt station at the utility's Michigan Electric Power Coordination Center was built after nearly 200 Detroit Edison customers subscribed to its SolarCurrents program. Under the program, open only to residential customers, subscribers pay an additional $\$ 6.59$ per month for each 100 watts of electricity. Each 100-watt block will provide a customer with about 140 kilowatthours of electricity per year. The system is expected to produce about 40.3 megawatthours annually (16.2 percent capacity factor) using 120 solar panels.

\section{Utility-Scale PV Investment Under Industry Restructuring}

Historically, a high-risk, high-return investment would be undertaken by independent power producers (IPPs) using leveraged, tax-favored financing. While this financial model is still valid in some cases, it has been adversely affected by current and proposed restructuring and deregulation of transmission and generation. In particular, the probable curtailment of power purchase agreements from unbundled transmission and distribution utilities and the prohibition by the Federal Energy Regulatory Commission (FERC) on wholesale purchases above avoided cost makes the competitive environment for high-risk IPPs much more difficult. Continued lowcost power from natural gas also reduces potential returns on PV projects.

Another major development under deregulation is the distinction between the cost of capital for generation investment and the cost of capital for transmission and distribution investment. Some studies have estimated increases of 3 to 5 percentage points in the cost of capital for generation investment and similar decreases in the cost of capital for transmission and distribution investment. Increases of this magnitude would effectively reduce the constant-dollar capitalized value rate for generation investment by roughly 15 to 20 percent. This change exceeds the value of benefits from existing tax credit and depreciation rules favoring nonregulated entities.

\footnotetext{
${ }^{135}$ D.E. Osborn and D.E. Collier, "Utility Grid-Connected Photovoltaic Distributed Power Systems."
} 
At present, dozens of utilities are investing nominal amounts of time and money to explore the opportunities for grid-interactive PV installations on their systems. Increases in grid-interactive PV system installations are likely to arise mostly from collaborative programs, such as PVUSA, or pursuant to regulatory requirements, including portfolio standards. Because PV systems are uneconomical regardless of how traditional or nontraditional benefits are measured, the balancing act for utilities and State commissions is between creating incentives for more installed capacity and creating measurable adverse impacts on competitive pricing.

For municipal utilities (such as SMUD) and rural electric cooperatives, both of which report directly to ratepayers but not to shareholders or FERC, the ability to expend funds for photovoltaics may be greater than for investor-owned utilities. For States that are willing to mandate portfolio standards at retail, as California is considering, the desire of the taxpaying public for certain types of energy sources must be balanced against the desire of the public for low-cost electricity. For quantities that would make a difference to the utility industry and the PV industry (i.e., 50 to 100 megawatts a year), costs to the public would be negligible. Beyond that, however, or in connection with other preferred but uneconomical energy sources (i.e., other renewables), the costs could become significant. Ultimately, photovoltaics will have to be judged on standard economic criteria. At present, they fall short by a factor of perhaps 6 , even if estimates of nontraditional benefits are included. If SMUD's plan for sustained orderly development is realized and costs for natural gas increase, photovoltaics could approach commercial competitiveness.

\section{Niche Markets}

The value of a PV system depends on the value of the energy and capacity it offsets and the nontraditional benefits it generates. These values differ widely from utility to utility and site to site. In general, systems that provide transmission and distribution (T\&D) support, such as Kerman or Hedge, are worth roughly $\$ 100$ to $\$ 200$ per kilowatt per year more than central station systems that supply bulk power. The exact difference between a T\&D support system and a central station system is highly sensitive to the characteristics of the T\&D system, the costs of extending the distribution lines, and other line-specific factors.

The niche market that appears to have captured the public's imagination is rooftop PV. Rooftop systems have many of the attributes of T\&D support systems, in that they reduce the load on distribution feeders and substations in essentially the same way as a centralized T\&D support system. Rooftop PV systems also have nocost land for siting. On the other hand, they have higher costs for utility overhead, marketing and administration, installation per kilowatt, and other scale diseconomies.

The key attribute of rooftop PV systems that makes them a potentially significant niche application is net metering. Under net metering, the customer's PV system offsets retail electric rates rather than wholesale avoided costs. Retail electric rates are typically several times greater than avoided costs. This difference creates considerable value for the residential customer at the expense of the utility. By valuing PV electricity at the retail offset (without a standby charge), the utility absorbs the costs above avoided cost. These costs include all the costs related to T\&D capital and operations, generating capacity, system overheads, etc. If PV market penetration were to become substantial, utilities would not be able to subsidize PV net metering. As a means of penetrating the market, however, the provision of net metering may be critical. To the extent that the use of net metering advances the PV market without substantially impairing the competitive position of the utility, the tradeoff may be beneficial to the utility in the long run. Ultimately, however, penetration of net metered technologies shifts costs from net metered customers to other customers. In a competitive market, absorption of these costs can only occur by regulatory direction.

PV technologies require cost reductions or a combination of cost reductions and an increase in natural gas prices to become cost-competitive in most grid applications. Some obstacles slowing commercialization are technology-specific, while others are more general. The primary obstacle is that $\mathrm{PV}$ technologies cannot currently compete with conventional fossil-fueled technologies in most grid-connected applications. On the other hand, niche applications, such as photovoltaics for T\&D support at the end of a fully loaded distribution line, have value above that of a new generating plant. Such applications may permit the technology to establish itself and benefit from economies of scale and learning effects.

Financial risk and uncertainty are also adversely affecting PV development. Because the technologies are costly and have high absolute capital costs per kilowatt of capacity, they are riskier than most conventional power plants. The risks are partially offset by the modularity of the plants and their short construction times, but their overall risk-adjusted cost of capital is high. 
An associated obstacle to solar development is the way in which electric utilities conduct their resource planning. Planning and avoided-cost methods currently cannot consider nonmarket benefits and costs, understating the social benefits of PV energy. For instance, the environmental benefits of using the sun to produce electricity are not usually explicitly accounted for in the resource planning process. Because the environmental benefits of using cleaner technologies are dispersed and accrue to the general public, the decisionmaking utility has no direct incentive to take them into account. Therefore, even though solar energy technologies impose little or no pollution cost on society, that benefit is generally left out of the least-cost planning process.

Despite some obstacles, PV energy technologies continue to enjoy success in certain market niches. PV is a versatile power source, and $\mathrm{PV}$ technologies have some unique attributes that drive their use in situations where most conventional energy technologies are not cost-effective. PV modules, as opposed to systems, have no moving parts to wear or break down, and they can be used for extended periods of time without maintenance or intervention. PV systems, however, have experienced a system degradation of 2 percent per year.

\section{Conclusion}

PV prices and the delivered cost of PV energy have declined substantially in recent years. Major progress has been made in all areas of module performance, reliability, and cost. Competitiveness with conventional forms of generation has been constrained, however, by declines in the price of natural gas, the surplus of coalfired energy, deregulation of generation, and other market factors. In most cases, PV systems are not currently economical for grid-interactive applications. Utilities are willing to invest money to develop a technical understanding of the technology and systems, and to respond to customer requests for "green" forms of energy. Given present uncertain market conditions, however, utilities are not willing to expend major investment funds to commercialize an uncompetitive technology at a utility plant scale.

As deregulation of generation increases and energy prices continue to decline, photovoltaics will face increasing competitive challenges. Utilities are mainly concerned with cost and price competition and customer retention. With increased competition, customer loyalty and retention are playing an increasingly important role in rutilities' decisionmaking. In some cases, a partial answer may be "green" pricing, in which consumers who choose to pay more for clean, renewable energy have the option to do so. In other cases, a partial answer may be portfolio standards. Under the portfolio standards approach, a utility that distributes at retail in a franchise service area is required to obtain part of its energy from renewable sources. Many jurisdictions, including California, are considering portfolio standards.

At current PV prices and levels of cost-competitiveness, public-private partnerships are the key to technology development. Partnerships such as UPVG and PVUSA combine the technical, economic, and regulatory expertise of many parties in ways that would not be financially feasible for the private sector alone. To a certain degree, the government role in these partnerships reflects the notion of societal benefits (reduced air emissions, reduced oil imports, etc.) that cannot be properly valued by electric utilities and nonutility generators. In the long term, photovoltaics must become more competitive in their own right-either through lower costs or through explicit recognition of the external costs of conventional energy supplies. 


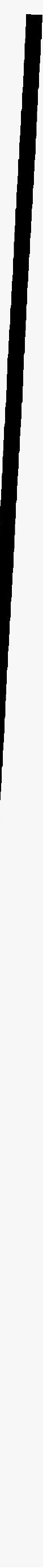




\section{Public Policy Affecting the Waste-to-Energy Industry}

\section{Introduction}

Public policy at the State, local, and Federal levels has been and continues to be the primary factor affecting the historic rise, recent leveling off, and near-term outlook of the municipal solid waste industry's contribution to the Nation's energy supplies. Environmental regulations and policies that at one time encouraged the combustion of waste into energy are currently emphasizing pollution control at waste-to-energy (WTE) facilities and recycling as the preferred waste disposal option. Federal tax policy no longer favors investments in capital-intensive projects such as WTE facilities. Energy regulations that once required utilities to buy energy from WTE facilities at favorable rates are being revamped to promote regional competition and lower energy prices. As the electric utility industry anticipates the effects of legislatively driven deregulation scenarios, the municipal solid waste (MSW) industry is already experiencing the effects of judicially driven deregulation decisions concerning their waste supplies.

To some extent, the MSW industry is a microcosm of the electric utility industry, and its current deregulation pains could provide insights into what lies ahead for the utility industry as a whole. Municipalities are currently making adjustments to protect their investments in waste facilities, a direct analogy to the "stranded assets" issue being debated in discussions of electric utility restructuring. Constitutional issues concerning the interstate flow of waste are currently working their way through the judicial system, and their resolution could ease the path or at least highlight similar problems that may arise as the electric utility industry is deregulated.

\section{Economic Status}

Municipal waste combustion is facing economically challenging times. Compared with the mid- to late 1980s, growth is slow. Major factors are the lack of adequate waste flows to projects; the growth of recycling, which has diverted potential waste from WTE facilities; successful court challenges to flow control and the interstate movement of waste, which have permitted private sector waste haulers and others to take refuse to the cheapest disposal sites; less favorable tax laws; and the reduction of revenues, particularly from electricity sales. Political considerations related to the siting and construction of WTE facilities constitute yet another challenge facing the industry.

In order to be economically viable, WTE projects have relied on (1) low capital costs, due to public financing, investment tax credits, and accelerated depreciation schedules; (2) a tipping fee structure, dependent on waste flow to amortize debt; and (3) revenues obtained from sale of electricity or steam or both. All of these elements are undergoing or have undergone change.

As a result of the Tax Reform Act. of 1986, it is more difficult to publicly finance projects that are not controlled entirely by a public entity. Two of the major advantages to private ownership, investment tax credits and depreciation schedules, have been eliminated and lengthened, respectively (see box on page 80 ). Traditionally, many WTE projects have been financed with public monies but operated and owned by private companies. This type of public/private sector arrangement no longer qualifies as "public purpose" under the law. States and localities are restricted in the amount of revenue bond financing for public/private sector joint ventures they can undertake, and solid waste projects must compete with many other infrastructure projects for financing. Thus, it is no longer easy to secure lowcost public financing for a privately owned and operated WTE project, and tax law changes have eliminated some of the advantages of private ownership.

Tipping fees are an essential part of a WTE project, comprising 50 to 70 percent of the operating revenue stream. They thus provide the bulk of revenues necessary to maintain an operating profit. When a facility is being planned, a certain amount of waste flow is projected and a tipping fee is set accordingly. Through interlocal agreements, contracts, and other arrangements, a project must secure a waste flow. In the past, "put or pay" contracts were signed, which obligated municipalities to provide a certain amount of waste to the facility and pay a per-ton fee even if the projected amount was not forthcoming. In addition, many facilities relied on flow control legislation to ensure that waste would be directed to the plant. 


\section{Taxes and Waste-to-Energy Facilities}

Changes in tax law are a major hurdle to building new WTE facilities. The elimination of tax credits, the extension of depreciation schedules, and other tax changes have reduced the amount of capital private firms are willing to invest to ensure that an acceptable and competitive rate of return can be maintained. Consider, for example, a 1,500-ton-perday WTE facility with capital costs of $\$ 150,000$ per ton and a typical operating capacity of 85 percent. A firm that would have been willing to invest 17.5 percent of total costs under the old tax laws now must limit that investment to only 6 percent of total costs under the new tax laws in order to maintain the same 15-percent rate of return on equity. The other 11.5 percent of the capital costs must be financed with additional bonds and paid for with higher tipping fees. Tipping fees would have to rise by approximately 14 percent to fund the additional debt.*

Being unable to bring as much financial clout to the bargaining table, private firms are in a substantially weakened negotiating position. Moreover, WTE facilities have typical life expectancies of approximately 40 years. Public ownership means that the benefits accrue to the public, rather than private individuals, for some time after the 25 -year bonds are paid off. Even if municipal governments decide against public ownership of WTE facilities, funding less capital-intensive waste disposal alternatives that are less significantly affected by the tax law changes requires smaller increases in tipping fees. A WTE facility, for example, may cost $\$ 100$ to $\$ 200$ million, whereas a landfill may cost only $\$ 20$ to $\$ 30$ million.**

\footnotetext{
*Based on cash flow analysis by David Livingstone of Smith Barney Shearson, one of the major underwriters of WTE bonds.

${ }^{* *}$ U.S. Government Accounting Office, Environmental Infrastructure: Effects of Limits on Certain Tax-Exempt Bonds, GAO/ RCED-94-2 (Washington, DC, October, 1993), p. 29.
}

Two major developments have occurred to upset this scenario. First, the amounts of waste initially projected by some of the WTE facilities did not materialize as expected; therefore, revenue targets were not met. Increased recycling, a lingering recession in certain areas throughout the early 1990s, and the availability of cheaper landfill space caused waste amounts available for combustion to drop. Localities challenged the "put or pay contracts" or waited until they ended and did not renew them. As waste flowed elsewhere or simply did not materialize, many WTE facilities had to raise tipping fees to meet debt and other obligations. The increase in tipping fees had the effect of driving more customers away, and some projects have found themselves in a downward spiral. The cost-effectiveness of WTE facilities could be enhanced in the future as the implementation of environmental legislation increases the cost of landfilling, but the effect could be offset by lower electricity prices as a result of deregulation.

National environmental policy is now causing waste streams to drop. Instead of encouraging incineration, the U.S. Environmental Protection Agency (EPA) is promulgating policy and providing technical guidance to promote waste reduction, reuse, and recycling. Municipal waste incineration is not a high priority.

A second development has been two Supreme Court decisions, Fort Gratiot Sanitary Landfill v. Michigan Department of Natural Resources (1994) and C\&A Carbone v. Clarkstown (1994). These decisions effectively struck down laws prohibiting waste from moving across county or State lines, as well as local ordinances mandating that waste be brought to a specific project. Such legislation was ruled to be protectionism and a violation of the constitutional right to free interstate commerce. (See Chapter 9 of this report for more detail.)

Electricity revenues are also under strain due to the many changes occurring in the U.S. electric utility industry. Through the early 1980s, the United States was still reacting to the oil crises that had occurred in the previous decade and the specter of expensive energy in the years to come. Government policies were put in place to encourage the development of alternative domestic energy sources. WTE was seen as one such alternative. Under the Public Utility Regulatory Policies Act of 1978 (PURPA), utilities were mandated to purchase electricity from alternative sources at an avoided cost rate. When energy prices were high, avoided costs ranged from 3 to 12 cents per kilowatthour. ${ }^{136}$ With lower electricity prices, revenues from the sale of electricity have fallen.

In addition, the Federal Energy Regulatory Commission (FERC) has ruled that special set-aside purchasing programs by utilities from alternative energy sites may not be permitted. Finally, with the ongoing deregulation of the utility industry, WTE electricity producers will have to compete in the marketplace to sell energy. Thus, just as public policy helped create the WTE industry, it is now a factor in slowing the industry's growth.

\footnotetext{
${ }^{136}$ Personal communication with Maria Zannes, Integrated Waste Services Association (October 16, 1996).
} 


\section{Siting Problems}

From a political standpoint, it is not popular to support the incineration of refuse, even if energy is recovered. Many citizen groups oppose the construction of any type of plant in their immediate neighborhoods. They are concerned about air pollution and its effect on their health. Other problems seen by individuals include excessive truck noise and odor.

On a local level, many zoning and environmental reviews must take place for a plant to be sited, with multiple opportunities for public review and comment. These procedures make permitting of a facility a long and difficult task that can take 5 to 7 years. ${ }^{137}$

Reflecting citizen concern, certain States and local governments have contemplated or imposed moratoria on the construction of WTE projects or passed laws that effectively limit construction of new facilities. This movement corresponds to the period in which the EPA was under pressure by environmental and other concerned groups to implement more stringent pollution standards. Examples include the following: ${ }^{138}$

- In October 1991, Rep. Kostmayer (D-PA) introduced a bill in the U.S. House of Representative (H.R. 3253, "The Pollution Prevention, Community Recycling and Incinerator Control Act") that included a moratorium on new MSW incinerators until the year 2000, in order to encourage recycling. After 2000 , incinerators could be built or expanded, but only if they comply with strict requirements. The bill did not become law, but it reflected the actions being taken at the State and local levels.

- The Wisconsin State legislature had before it a bill to impose a 2-year moratorium on the issuance of air permits for new WTE facilities, commencing in 1992. After debate, the bill did not pass.

- The State of Florida Department of Environmental Regulation, as a result of the lack of publication of new EPA standards on air emissions and mercury controls and the desire to create time to assess the need for new incinerators, strongly supported a 2year moratorium on construction, beginning in mid1992. A measure was introduced in the Florida House to that effect. Ultimately, in 1993 Florida imposed tough mercury standards in advance of the EPA's regulations. These were the toughest in the country at the time.
- The Baltimore City Council passed a 5-year moratorium on new incinerators, beginning in 1992.

- On July 14, 1992, the Governor of Rhode Island signed into law the State's 1993 budget, containing an amendment (Article 101) prohibiting the Rhode Island Solid Waste Management Corporation from building two WTE facilities that had been procured.

- New Jersey implemented a 4-month moratorium on the construction of new waste incinerators from May 1990 to August 1990. In 1991, the State implemented solid waste policies that constituted a de facto moratorium on incinerator development. In essence, the policies had as their goals to minimize incineration, regionalize solid waste disposal facilities, and reach a 60-percent recycling goal by 1995 .

- A new focus, "environmental justice," has emerged at the State and local levels in the past few years. A number of States, including California, New York, Florida, Michigan, Minnesota, and Virginia, have introduced bills or passed into law legislation that imposes restrictions on the siting of "high-impact environmental projects" (such as incinerators) in low-income areas with a high percentage of minority residents.

On the other hand, the more restrictive air emission standards promulgated by the EPA in 1995 may satisfy some critics and, at least in part, remove a significant barrier to the growth of the WTE industry.

\section{Legal Issues (Flow Control)}

The Commerce Clause of the U.S. Constitution prohibits State or local regulations that discriminate against outof-State commerce to protect local economic interests. In 1978, the Supreme Court held that household garbage was "commerce" within the meaning of the Commerce Clause and that New Jersey's attempt to preserve landfill capacity for in-State garbage was unconstitutional. ${ }^{139}$ This and subsequent cases have been interpreted to mean that a State may not prohibit a private landfill or waste disposal facility from accepting out-ofState garbage or imposing a surcharge or tax on such waste. The Court has consistently found no rational basis for restricting or surcharging out-of-State wastes. ${ }^{140}$ The Court has extended its rulings to include "hazardous" waste within the scope of the Commerce Clause. ${ }^{141}$

\footnotetext{
${ }^{137}$ Personal communication with Maria Zannes, Integrated Waste Services Association (October 16, 1996).

${ }^{138}$ Personal communication with Eileen Berenyi, Governmental Advisory Associates, Inc. (October 18, 1996).

${ }^{139}$ Philadelphia v. New Jersey, 437 U.S. 617 (1978).

${ }^{140}$ Fort Gratiot Sanitary Landfill, Inc. v. Michigan Dept. of Natural Resources, 112 S. CT. 2019 (1992); Oregon Waste Systems, Inc. v. Department of Environmental Quality, 114. Ct. 1345 (1994).

${ }^{141}$ Chemical Waste Management, Inc. v. Hunt, 112S. CT. 2009 (1992).
} 
The basic principle of these opinions, that local regulation may not discriminate against interstate commerce solely to advance local economic interests, has been applied to strike down local flow control ordinances. In 1994, in C\&A Carbone, Inc. v. Town of Clarkstown (Carbone), the Supreme Court held that a law requiring all locally produced solid waste to be processed at a local processing business violated the Commerce Clause. ${ }^{142}$ In Carbone, the town adopted a flow control ordinance requiring all nonhazardous solid waste within Clarkstown, New York, to be processed at the town transfer station. The purpose of the ordinance was to subsidize construction of the transfer station; its effect was to eliminate competition from other processors in the town. The Court found the local regulation to be a trade barrier against competition from out-ofState waste processors and, therefore, unconstitutional. Other courts have followed the holding in Carbone. For example, the Third Circuit Court of Appeals struck down a New Jersey flow control ordinance, and a Middle District of Georgia court struck down local measures designed to ensure that waste would remain in the local market.

The Carbone decision is significant because financing for WTE facilities is typically secured through a guarantee of revenues from tipping fees and energy sold. To ensure an ample supply of waste resources, and ultimately revenue, local governments passed ordinances mandating that local waste be sent to the local facility. Such ordinances favor local facilities strictly on the basis of location and deprive waste haulers of the opportunity to seek the least expensive disposal alternative.

The Supreme Court's decision makes financing of WTE projects more difficult and more expensive due to the increased risk. As evidence of this point, a recent U.S. Court of Appeals decision for the Third Circuit following the Carbone ruling (Summer 1995) invalidated a New Jersey flow control ordinance. Shortly thereafter, Moody's Investor Service downgraded the credit ratings for five New Jersey WTE facilities. However, several cases decided by Federal courts have clarified the extent to which flow control in municipal contracts with private haulers can be legally implemented (see Chapter 9).

\section{Environmental Regulations}

\section{Clean Air Act}

The WTE industry is regulated under a number of environmental programs administered by the EPA and

\section{Background of CAA Regulations for Municipal Waste Combustors}

On December 20, 1989, the EPA proposed new guidelines and standards for municipal waste combustors (MWCs) under the authority delineated in Section 111 of the Clean Air Act of 1977 (CAA). Regulation in the 1989 guidelines and standards was based on "best available control technology" or "BACT." The new standards were promulgated on February 11, 1991, for new MWCs, and guidelines were issued for existing MWCs.

On November 15, 1990, amendments to the CAA were enacted by Congress and signed into law. The amendments added Section 129 to the CAA, specifying that standards and guidelines be developed for both large and small MWCs and that revised standards and guidelines reflect more restrictive performance levels than those included in the 1991 regulations.

Section 129 established a schedule for revising the 1991 standards and guidelines and implementing new standards, which EPA did not meet. As a result, the Sierra Club, the Natural Resources Defense Council, and the Integrated Waste Services Association filed a complaint in U.S. District Court. Under a consent decree, EPA was required to promulgate new standards no later than October 31, 1995, which were published as of December 19, 1995.

The 1995 revised standards are more stringent than those issued in 1991. In addition, the revised standards apply to all MWCs above 35 megagrams (about 40 tons) per day, not just to large MWCs above 225 megagrams (about 250 tons) per day, as the earlier standards and guidelines did.

Under the December 1995 rule, New Sources are defined as those MWCs that began construction after September 20,1994, or began modification or reconstruction after June 19, 1996. MWCs constructed, modified, or reconstructed between December 20, 1989, and September 20, 1994, continue to be regulated under the 1991 standards; however, they must be upgraded to reduce mercury and fugitive ash emissions to the 1995 guidelines.

State regulatory agencies. In October 1995, the EPA promulgated new Clean Air Act (CAA) regulations for municipal waste combustors, including WTE plants. These CAA standards govern much of the design and operation of waste-fueled power plants.

${ }^{142}$ CEA Carbone, Inc. v. Town of Clarkstown, New York, No. 114, S. Ct. 1677 (1994). 
The 1990 CAA amendments call for the EPA to establish new air emission limits for everything that emits pollution, from power plants to lawn mowers. As part of this sweeping environmental mandate, EPA Administrator Carol Browner signed air pollution control standards in 1995 called "Standards of Performance for New Stationary Sources and Emission Guidelines for Existing Sources: Municipal Waste Combustors." The New Source Performance Standards regulate facilities built after 1995. The Emission Guidelines regulate existing, operating facilities. The Emission Guideline standards are intended to ensure that facilities use the "maximum achievable control technology" or "MACT." The rules apply to all new and existing WTE plants and incinerators with the capacity to burn more than 40 tons of garbage per day.

In total, the EPA estimated that about 130 plants (including those that do not convert waste into energy or do not market energy) will be covered by the MACT rule. Many existing facilities currently are designed with state-of-the-art high-temperature combustion systems, scrubbers, and baghouses or high-efficiency electrostatic precipitators and can meet the new emission limits with relatively minor or no equipment additions. Other facilities must make significant retrofits to their existing air pollution control equipment.

Shortly after promulgation of the MACT standards, Davis County Solid Waste Management District, Waste Energy Partners, and the Cement Kiln Recycling Coalition brought suit against the EPA, challenging the standards for existing facilities. The petitioners contended that EPA inappropriately based emission limits on the size of a facility versus the size of an individual unit at a facility. Nearly a year after the CAA rules were promulgated by the EPA (December 6, 1996), the U.S. District Court of Appeals for the District of Columbia handed down a decision that would vacate the rules. However, the decision left open possibilities for the EPA to keep intact the rules for large facilities and a significant number of small facilities while repromulgating rules for a smaller category of facilities.

Under the MACT rules as originally written, facilities with design capacity under 250 tons per day had a different set of emission limits than those with design capacity greater than 250 tons per day. This simple division based on facility and not unit size led to situations where facilities with three 100-ton-per-day units (furnaces) would have to meet the emission standards for large facilities despite the fact that a facility with only two of the same 100-ton-per-day units would meet the substantially less stringent standards for small facilities. The Court decision instructed EPA to correct the MACT and NSPS rule by basing emission limits on unit size at facilities.

EPA may file a motion within 45 days of the Court decision for reconsideration by the Court and requesting that the standards for large and many small units not be vacated. If the Court does not reverse its decision by mid-February, EPA contends that it could repromulgate the rule for large facilities within a short time and without changing the standards. Large facilities account for more than 80 percent of the design capacity in the United States.

The Court decision has not slowed retrofit schedules at facilities, especially at large facilities that may not be significantly impacted if EPA promulgates its rules within the year. Minor changes to plant design and operations have been accomplished since promulgation in 1995. Some of the more extensive retrofits-such as adding a scrubber and baghouse-are still on schedule to be completed within 1 to 3 years after States adopt the Federal rules, but no later than the year 2000. EPA estimates a household might pay less than 5 cents to as much as 3 dollars a month more for disposal at facilities that must add new pollution control equipment. Technologies that will be added to existing facilities include a baghouse, scrubber, selective noncatalytic reduction (SNCR), and carbon injection systems (see box on page 84 ).

EPA estimated that the MACT rule will reduce emissions of cadmium, lead, mercury, dioxin, sulfur dioxide, hydrogen chloride, nitrogen dioxide, and particulate matter by approximately 145,000 tons per year. Based on emissions data collected by EPA, full implementation of the rule will reduce dioxin emissions from MWCs by at least 99 percent, so that MWCs will represent less than 1 percent of the known sources of dioxin when the rule is implemented. EPA also estimated that the rule will yield about a 90-percent reduction in emissions of mercury from the facilities, based on 1990 levels, so that MWCs will represent about 3 percent of the U.S. inventory for mercury emissions. ${ }^{143}$

The emission guidelines for existing facilities set emission limits for dioxin/furans, cadmium, lead, mercury, sulfur dioxide, hydrogen chloride, particulate matter, opacity, nitrogen oxides, fugitive emissions, and carbon monoxide. The new source rule includes stringent limits on particulate matter, opacity, sulfur dioxide, hydrogen chloride, dioxin/furans, nitrogen

\footnotetext{
${ }^{143}$ U.S. Environmental Protection Agency, "Final Air Regulation for Municipal Waste Combustors," fact sheet (October 31, 1995).
} 


\section{MACT Standards: New Clean Air Act Rules for Waste-to-Energy Facilities}

Some facilities currently are designed to meet the new emissions limits. Others must add or retrofit newer technology to their existing air pollution control equipment. Minor changes to plant operations may be accomplished soon. More extensive retrofits will be completed no later than the year 2000. Retrofit technologies include:

- A "bag house" that works like a giant vacuum cleaner with hundreds of fabric filter bags which clean the air of soot, smoke, and metals.

- A "scrubber" which sprays a slurry of lime into the hot exhaust. The lime neutralizes acid gases, just as a gardener uses lime to neutralize acidic soil. Scrubbing also can improve the capture of mercury in the exhaust.

- "Selective noncatalytic reduction" (SNCR) that converts nitrogen oxides-a cause of urban smog-to harmless nitrogen by spraying ammonia or urea into the hot furnace.

- "Carbon injection systems" that blow charcoal into the exhaust gas to absorb mercury. Carbon injection also controls organic emissions such as dioxins.

MACT Rules for Existing Plants

\begin{tabular}{|c|c|c|c|}
\hline Emission & Limit & Emission & Limit \\
\hline $\begin{array}{l}\text { Dioxin/Furans } \\
\text { Small } \\
\text { Large } \\
\text { ESP-equipped units } \\
\text { All others } \\
\end{array}$ & $\begin{array}{l}\text { (/dscm) } \\
125 \mathrm{ng} \\
60 \mathrm{ng} \\
30 \mathrm{ng} \\
\end{array}$ & $\begin{array}{l}\mathrm{SO}_{2} \\
\mathrm{Small} \\
\text { Large }\end{array}$ & $\begin{array}{l}80 \mathrm{ppm} \text { or } 50 \% \text { removal } \\
31 \mathrm{ppm} \text { or } 75 \% \text { removal }\end{array}$ \\
\hline $\begin{array}{l}\text { Cd } \\
\text { Small } \\
\text { Large }\end{array}$ & $\begin{array}{l}\text { (/dscm) } \\
0.10 \mathrm{mg} \\
0.04 \mathrm{mg}\end{array}$ & $\begin{array}{l}\mathrm{HCl} \\
\text { Small } \\
\text { Large }\end{array}$ & $\begin{array}{l}250 \mathrm{ppm} \text { or } 50 \% \text { removal } \\
31 \mathrm{ppm} \text { or } 95 \% \text { removal }\end{array}$ \\
\hline \multirow{2}{*}{$\begin{array}{l}\mathrm{Pb} \\
\text { Small } \\
\text { Large }\end{array}$} & \multirow{2}{*}{$\begin{array}{l}(/ \mathrm{dscm}) \\
1.6 \mathrm{mg} \\
0.49 \mathrm{mg} \\
\end{array}$} & Opacity & $10 \%$ \\
\hline & & $\mathrm{Hg}(/ \mathrm{dscm})$ & $0.080 \mathrm{mg}$ or $85 \%$ removal \\
\hline $\begin{array}{l}\text { Particulates } \\
\text { Small } \\
\text { Large }\end{array}$ & $\begin{array}{l}70 \mathrm{mg} \\
27 \mathrm{mg}\end{array}$ & Fugitives & $\begin{array}{l}\text { Visible less than } 5 \% \text { of the } \\
\text { time }\end{array}$ \\
\hline \multicolumn{4}{|c|}{$\begin{array}{l}\text { NO }_{\mathbf{x}} \text { : Operator of large plants may select one of twe } \\
\text { Option A: Units must meet the following standards: }\end{array}$} \\
\hline $\begin{array}{l}\text { Mass Burn/Waterwall } \\
\text { RDF } \\
\text { Mass Burn Rotary }\end{array}$ & $\begin{array}{l}200 \mathrm{ppm} \\
250 \mathrm{ppm} \\
250 \mathrm{ppm}\end{array}$ & $\begin{array}{l}\text { Fluidized Bed } \\
\text { Refractory } \\
\text { Other }\end{array}$ & $\begin{array}{l}290 \mathrm{ppm} \\
\text { Exempt } \\
210 \mathrm{ppm}\end{array}$ \\
\hline \multicolumn{4}{|c|}{ Option B: Plants may "bubble" units within the plant to meet the following standards: } \\
\hline $\begin{array}{l}\text { Mass Burn/Water Wall } \\
\text { RDF } \\
\text { Mass Burn Rotary }\end{array}$ & $\begin{array}{l}180 \mathrm{ppm} \\
230 \mathrm{ppm} \\
220 \mathrm{ppm}\end{array}$ & $\begin{array}{l}\text { Fluidized Bed } \\
\text { Refractory } \\
\text { Other }\end{array}$ & $\begin{array}{c}260 \mathrm{ppm} \\
\text { Exempt } \\
190 \mathrm{ppm}\end{array}$ \\
\hline $\begin{array}{l}\text { Co } \\
\text { Modular } \\
\text { Mass Burn } \\
\text { Rotary/Waterwall, } \\
\text { Refractory, Fluidized Bed }\end{array}$ & $\begin{array}{l}50 \mathrm{ppmv} \\
100 \mathrm{ppmv}\end{array}$ & $\begin{array}{l}\text { Mass Burn } \\
\text { Rotary/Waterwall } \\
\text { Pulverized Coal, RDF } \\
\text { Mixed } \\
\text { Spreader Stoker Coal/ } \\
\text { RDF Mixed, RDF Stoker }\end{array}$ & $\begin{array}{l}250 \mathrm{ppmv} \\
150 \mathrm{ppmv} \\
200 \mathrm{ppmv}\end{array}$ \\
\hline
\end{tabular}

(Continued on page 85) 
MACT Standards: New Clean Air Act Rules for Waste-to-Energy Facilities (Continued)

MACT Rules for New Plants

\begin{tabular}{|lc|lc|}
\hline \multicolumn{1}{|c|}{ Emission } & Limit & \multicolumn{1}{c|}{ Emission } & \multicolumn{1}{c|}{ Limit } \\
\hline Dloxin/Furans & $13 \mathrm{ng} / \mathrm{dscm}$ & $\mathrm{SO}_{2}$ & $30 \mathrm{ppm}$ or $80 \%$ removal \\
\hline $\mathrm{Cd}$ & $0.020 \mathrm{mg} / \mathrm{dscm}$ & $\mathrm{HCl}$ & $25 \mathrm{ppm}$ or $95 \%$ removal \\
\hline$/ \mathrm{Pb}$ & $0.20 \mathrm{mg} / \mathrm{dscm}$ & Opacity & $10 \%$ \\
\hline $\mathrm{PM}$ & $24 \mathrm{mg}$ & $\mathrm{Hg}(/ \mathrm{dscm})$ & $0.080 \mathrm{mg}$ or $85 \%$ removal \\
\hline Fugitives & $\begin{array}{l}\text { Visible less than } 5 \% \text { of the } \\
\text { time }\end{array}$ & $\begin{array}{l}\mathrm{NO}_{x} \\
\text { First year } \\
\text { After 1st year }\end{array}$ & $\begin{array}{l}180 \mathrm{ppm} \\
150 \mathrm{ppm}\end{array}$ \\
\hline $\begin{array}{l}\text { Co } \\
\text { Modular/Mass Burn } \\
\text { Fluidized Bed RDF }\end{array}$ & $100 \mathrm{ppmv}$ & Complete & $\begin{array}{l}\text { Siting Analysis } \\
\text { Materials Separation Plan } \\
\text { Public Meetings }\end{array}$ \\
\hline
\end{tabular}

dscm $=$ dry standard cubic meter.

Note: Small plants include facilities that burn between 38 tons but no more than 250 tons per day. Large plants are defined as those that burn more than 250 tons per day of waste.

Source: Integrated Waste Services Association, "Waste-to-Energy Environmental Rules Among World's Toughest" (Washington, DC, November 1, 1995).

oxides, cadmium, lead, carbon monoxide, and mercury. Specific requirements are included in the rule governing new plants for public participation and materials separation/recycling plans. The regulation allows local communities to consider their unique circumstances in helping to plan for new plants, including the design of materials separation/recycling plans.

States in which WTE plants are located must submit a State implementation plan (SIP) by December 31, 1996, including standards that are at least as stringent as those promulgated by EPA. After States adopt the final rule and EPA has approved the SIP, large combustors burning more than 250 tons of trash per day will have 1 year to comply with the regulation. The MACT rule does provide for up to 3 years for compliance in special, case-by-case circumstances. Small combustors burning less than 250 tons of trash per day will have 3 years to comply with the regulation. EPA estimated the total nationwide annual cost of the regulation at $\$ 488$ million for new and existing sources. ${ }^{144}$

\section{The Resource Conservation and Recovery Act: Municipal Solid Waste Combustor Ash}

The Resource Conservation and Recovery Act (RCRA) governs the disposal of solid and hazardous waste, including testing requirements to determine the characteristics of waste. The solid waste law contains an exemption for WTE facilities, allowing that household trash burned in the plant is not subject to testing. The WTE industry long held the view that the exemption extended to the ash residue remaining after the burning process. But in 1994, the Supreme Court ruled that although the RCRA statute specifically exempts facilities from testing incoming trash, the exemption does not extend to the remaining ash. As a result of the Supreme Court decision, WTE facilities began testing ash for its hazardous characteristics in accordance with the Toxicity Characteristic Leaching Procedure (TCLP) that subjects ash to acidic liquid, causing metals to leach from the material. If metals leach in amounts greater than a fraction of a percent, the ash is considered hazardous. After years of testing, the ash has consistently passed TCLP, thus remaining acceptable for disposal at municipal landfills.

The EPA issued a series of decisions and interpretative directives to States concluding that the ash should be tested when it first meets the environment-most often as it is loaded onto trucks prior to being shipped to a landfill or other use. These EPA decisions allow facilities to mix fly and bottom ash before testing and disposal. Fly ash, which is captured from stack gases, tested by itself, may have a much higher proportion of heavy metals, polyaromatic hydrocarbons, and dioxins than bottom ash. EPA also issued a detailed guidance document governing how the TCLP test should be

${ }^{144}$ U.S. Environmental Protection Agency, "Final Air Regulation for Municipal Waste Combustors." 
administered. The Supreme Court decision, coupled with the EPA's directives, has settled the issue of ash disposal for the WTE industry into the foreseeable future.

A sense of certainty has led local officials and State regulators to consider the beneficial use of ash. The most common use for ash is as landfill roadbed material and daily and final landfill cover. Pilot projects are underway in more than a dozen States to test the physical properties of ash for use in road aggregate, granular base, asphalt mixture, and the construction of artificial reefs and cement blocks. Ash represents about 10 percent by volume of the trash combusted. Ferrous metals are removed at the facility, leaving a residue that looks like wet cement. WTE residue has physical properties similar to construction mixtures such as concrete or asphalt. After a short time, the ash cures and resembles concrete, thus making commercial use possible (see box on page 87 ).

A major advantage of combusting waste is that it permits the recycling of high-grade ferrous metals. Last year the industry recycled almost 740,000 tons of ferrous metals. These metals are unique residuals of the combustion process and most would not otherwise be available for recovery. ${ }^{145}$

\section{Utility and Energy Regulations}

\section{The Public Utility Regulatory Policies Act of 1978}

The Public Utility Regulatory Policies Act of 1978 (PURPA), as implemented by the Federal Energy Regulatory Commission (FERC), requires utilities to buy power from qualifying facilities (QFs), which can be either qualifying cogeneration facilities (generators of thermal as well as electrical energy) or qualifying small power production facilities (generators of electrical energy using specified energy sources). WTE facilities of 80 megawatts or less can qualify as small power production facilities. Other types of non-WTE projects can qualify as well if they meet FERC requirements.

FERC does not set the purchase price, but utilities must purchase energy produced by the QFs at a price which is "fair and reasonable" and nondiscriminatory, or the utility's avoided cost. FERC, responsible for the oversight of the implementation of PURPA, delegated the responsibility of the avoided cost calculation to the States and their respective public utility commissions.
Avoided cost was defined as the utility's marginal cost of the production or purchase of energy. Over time, however, "competitive bidding" displaced avoided costs as the accepted method of determining a price that is fair and reasonable. Competitive bidding eliminated much of the arbitrariness associated with determining the rate utilities must pay QFs for their electric power.

Because of PURPA, there was substantial growth in the market for power produced by the independent power industry including WTE projects. However, as fossil fuel prices have dropped, total generating capacity has increased, and the wholesale utility market has become increasingly competitive, avoided costs have dropped throughout the country.

\section{Energy Policy Act of 1992}

The Energy Policy Act of 1992 (EPACT) created a new class of wholesale-only electric generators-"exempt wholesale generators" (EWGs)-which are exempt from the Public Utility Holding Company Act of 1938. EPACT dramatically enhanced competition in U.S. wholesale electricity generation markets, permitting broader participation by subsidiaries of electric utilities and other nonqualifying facilities. Under the Act, EWG status for WTE facilities and other generators is obtained on a case-by-case basis from FERC. Because the law does not target generators by size, type of fuel, or technology, it has limited the competitive advantage of QFs in the wholesale power marketplace as States accelerate the trend toward all-source bidding, in which all facilities compete to be the lowest bidder. In this environment, the WTE has no advantage unless credit is given to renewable fuels.

\section{Recent Decisions}

In response to a filing by Connecticut Light \& Power, FERC held that PURPA prohibits a State from mandating utility purchases from QFs above avoided cost. In another decision, FERC overturned an order by the California Public Utility Commission that required regulated utilities to purchase specified quantities of energy from renewable sources. The ruling was based on the rationale that such purchases would lead to prices in excess of avoided cost. In New York, six of the State's seven investor-owned utilities recently relied on the FERC's order in the California case to withdraw from a New York Public Service Commission approved ruling calling for the purchase of 300 megawatts of renewable energy from independent producers.

\footnotetext{
${ }^{145}$ Integrated Waste Services Association, The 1996 IWSA Municipal Waste Combustion Directory of United States Facilities (Washington, DC, May 1996), p. 10.
} 
In 1996, FERC issued Order 888, dealing with openaccess transmission, and Order 889, dealing with stranded costs. The open access transmission rule functionally unbundles transmission from generation by requiring utilities to open their transmission systems to all wholesale transmission on a real-time, nondiscrimi- natory basis. Many issues related to regional control, system stability, and network pricing versus point-topoint pricing remain to be decided. Priority issues among native load and other customers and jurisdictional issues between retail and wholesale customers are still unclear.

\section{State Waste-to-Energy Ash Reuse Projects}

\section{California}

- Since 1991, combined ash from the Commerce Refuse-to-Energy Facility has been used as subbase for roads at the Puente Hills Landfill in Whittier (Los Angeles County).

- The City of Long Beach uses ash as daily cover at the county landfill.

\section{Connecticut}

- Ash from the Bridgeport WTE plant has been used since 1988 as a grading cap over a discontinued MSW/hazardous waste landfill.

- The Connecticut Resources Recovery Authority used an ash-asphalt mixture from the Bridgeport facility in 1992 to pave a 600-foot access road at its Shelton Landfill.

\section{Florida}

- Starting in 1984, Pinellas County WTE ash has been used as daily landfill cover and for roadbase/berm construction on a site owned and operated by the county.

\section{Hawaii}

- Honolulu's WTE plant is studying and demonstrating the reuse of its ash as landfill cover and roadbed construction material.

\section{Massachusetts}

- In January 1992, an access road to the SEMASS WTE facility on Cape Cod was built using ash in the pavement subbase and in both the top and base courses. The parking lot at the facility has an ash material subbase.

- In 1979, combined ash from the Saugus WTE plant was used on nearly a mile of Route 129 in Lynn as part of an asphalt pavement mixture. A Federal Highway Administration report found that the roadway was in excellent condition.
- Ash from the Saugus WTE plant has been used as a grading cap over a discontinued MSW landfill since 1975.

\section{New Hampshire}

- In May 1993, a 1,150-foot stretch of U.S. Route 3 in Laconia was paved with a mixture of asphalt and ash from the Concord WTE facility.

\section{New Jersey}

- In July 1996, 750 feet of Center Drive in Elizabeth was paved with a mixture of asphalt and ash from the Warren County WTE facility.

\section{New York}

- In 1990, the New York State Department of Environmental Conservation granted approval to Islip for the use of ash as a gas venting layer material in the closure of the Blysdenburg Landfill.

- In October 1990, researchers at the State University of New York (SUNY) used more than 9,000 ash blocks to build a boathouse on the SUNY campus at Stony Brook, Long Island. Air quality monitoring and other tests have indicated no adverse environmental impacts.

- In 1987 and 1988, SUNY researchers built two artificial reefs, one using ash blocks and the other using cement concrete, in Conscience Bay off Long Island. The ash blocks have shown no deterioration of structural integrity (the standard blocks are breaking apart) and are not adversely impacting the environment.

\section{Ohio}

- In 1991, the Montgomery County Department of Solid Waste Management built an ash management building from ash blocks, using ash from the county's mass burn facilities.

(Continued on page 88) 


\section{State Waste-to-Energy Ash Reuse Projects (Continued)}

\section{Pennsylvania}

- The Pennsylvania Department of Environmental Protection, in October 1993, approved the use of ash at the Lanchester Landfill in Honey Brook as daily cover and as roadbed material for on-site roads.

- A portion of the ash from a waste-to-energy facility in Camden County, New Jersey, is used as daily cover material at a landfill in Pennsylvania.

\section{Tennessee}

- Ash from the Sumner County Resource Authority's Nashville facility is marketed as structural fill for use in road construction.

\section{Texas}

- The Federal Highway Administration in 1974 and 1977 used combined ash as a road base material on an access roadway and residential street in Houston. Ongoing monitoring for engineering performance indicated that ash was acceptable as a construction material.

\section{Virginia}

- Blocks produced from MWC ash and concrete were used to construct about 150 feet of revetment to help restore a badly eroded section of beach at Rudee Inlet near Virginia Beach. 


\section{Flow Control and the Interstate Movement of Waste: Post-Carbone}

Flow control is the ability to ensure that waste from a certain area is delivered to a designated facility. ${ }^{146}$ Flow control can be of a legal or economic nature (see box on page 90). Legal or legislated flow control occurs when State or local governments, acting in their capacity as waste "regulators," enact laws, regulations, and ordinances directing the flow of waste to particular facilities. Economic flow control has similar objectives, but the government uses tools such as subsidies and taxes rather then legislation to control the flow of waste.

\section{Background}

Almost a century ago, the U.S. Supreme Court ruled that garbage collection and disposal are core responsibilities of local governments. ${ }^{147}$ Local governments may directly provide waste services through public employees or independent contractors, or they may regulate the private market. However, these historic Supreme Court decisions did not address whether municipal waste management systems were in compliance with the Commerce Clause of the U.S. Constitution. This controversial issue, which significantly affects everyday life in our solid waste management systems, is creating much uncertainty as it works its way through the judicial system.

After years of unsuccessfully challenging various flow control ordinances, plaintiffs have recently won key decisions. On May 16, 1994, the Supreme Court issued a landmark decision in C\&A Carbone, Inc. v. Town of Clarkstown, New York (Carbone), ${ }^{148}$ declaring the town's flow control ordinance unconstitutional on the grounds that it unfairly regulated interstate commerce and, therefore, violated the Commerce Clause. The Carbone decision is having a major impact on the way the waste industry does business. At the end of 1993, there were 114 waste-to-energy (WTE) facilities marketing energy in the United States, 55 of which used legal flow control to direct local waste streams. From 1990 to 1993, 21 facilities using legal flow control became operational compared and only 3 facilities that used private contracts or no contracts to secure waste supplies. ${ }^{149}$ Since most flow control practices are now subject to dispute and litigation, municipalities are maneuvering to implement more legally defensible procedures to protect their investments in existing waste facilities.

The Carbone decision followed a 1992 decision $^{150}$ (excluding Carbone there have been three other Supreme Court cases since 1978 involving a Commerce Clause challenge to restrictions or taxes on waste disposal ${ }^{151}$ ) in which the Supreme Court declared Michigan's solid waste management law that prohibited private landfills from accepting out-of-State waste to be in violation of the Commerce Clause and, therefore, unconstitutional. The ruling held that Michigan's import restrictions are protectionist measures in that they "unambiguously" discriminate against interstate trade. The Court further stated that "a State (or one of its political subdivisions) may not avoid the strictures of the Commerce Clause by curtailing the movement of articles of commerce through the subdivisions of the State, rather than through the State itself." The Court ruled that the Michigan counties could provide safe disposal of future waste streams without discriminating among wastes from different origins.

\footnotetext{
${ }^{146}$ For more information on the history of flow control, see J. Carlin, "The Impact of Flow Control and Tax Reform on Ownership and Growth in the U.S. Waste-to-Energy Industry," in Energy Information Administration, Monthly Energy Review, DOE/EIA-0535(94/09) (Washington, DC, September 1994); and W.L. Kovacs, "Flow Control of Solid Waste: The Continuing Conflict Between Free Competition and the Public Policy of Integrated Waste Management," Resource Recovery Report (Washington, DC, 1996).

${ }^{147}$ California Reduction Co. v. Sanitary Reduction Works, 199 U.S. 306, 50 L. Ed. 204, 26 S. Ct. 100 (1905); Gardner v. Michigan, 199 U.S. 325 , 50 L. Ed. 212, 26 S. Ct. 106 (1905).

${ }^{148}$ CEA Carbone, Inc. v. Town of Clarkstown, New York, No. 114, S. Ct. 1677 (1994).

${ }_{149} \mathrm{~J}$. Carlin, "The Impact of Flow Control and Tax Reform on Ownership and Growth in the U.S. Waste-to-Energy Industry."

${ }^{150}$ Fort Gratiot Landfill v. Michigan Department of Natural Resources, 504 U.S. 353 (1992).

${ }^{151}$ Philadelphia v. New Jersey, 437 U.S. 617 (1978); Chemical Waste Management v. Hunt, 504 U.S. 334 (1992); and Oregon Waste Systems v. Department of Environmental Quality, 114 S. Ct. 1345 (1994).
} 


\section{Flow Control Characteristics}

Generally, flow control can be defined as the laws, regulations, and economic incentives or disincentives used by waste managers to direct waste generated in a specific geographic area to a designated landfill, recycling, or waste-to-energy (WTE) facility. In some cases, the waste may be delivered first to a transfer station, then sorted and reshipped. The specific form and mix of controls instituted by State and local governments depend on the objectives desired.

By far the most frequently used rationale for flow control is to ensure the financial viability of a WTE facility by providing a reliable, long-term supply of raw materials. This ensures the facility of obtaining revenues from tipping fees (charges for waste disposal at the facility) and the sale of electricity or steam or both, and, in some cases, from the sale of materials for recycling, depending on the type of waste disposal facility designated to receive the waste. This assurance is critical in raising capital to finance the construction of a facility.

Legal flow control can be implemented in several ways. The municipality use government employees and vehicles to collect and dispose of the waste, contract with private haulers for some portion of the process, or grant permits, licenses, or franchises for the collection, transportation, and disposal of waste only to those entities that deliver the waste to a designated facility. Local laws and ordinances to direct waste flows are usually authorized, required, or supported by State governments.

Economic flow control combines market forces with tools such as subsidies, grants, fees, and taxes to the extent necessary to control waste flows. It attempts to direct the movement of waste without legal or regulatory controls. The distinction between legislated and economic flow control is critical to the development of defense strategies against legal challenges.

Publicly owned WTE facilities and certain privately owned facilities that are affiliated with municipalities can engage in either legal or economic flow control. "Merchant facilities," which are independently constructed by entrepreneurs without municipal involvement in guaranteeing waste flows, usually employ private contracts to secure waste supplies.

\section{Path Around the Carbone Decision}

Recently, the judicial system has applied the guidance gained from the two Supreme Court decisions mentioned above, and in so doing has identified a path that may enable municipalities to restructure their current arrangements to be exempt from or in compliance with Commerce Clause strictures. To understand why flow control ordinances violate the Commerce Clause while certain practices such as "exclusive municipalization of waste disposal services" have been ruled valid by the judicial system, it is necessary to understand the judicial system's past reasoning and interpretations.

\section{Legal Background}

The Commerce Clause has been interpreted by the Supreme Court to prohibit States from discriminating against or unduly burdening interstate commerce. The Commerce Clause is applicable to State and local governments that are "regulating" the market but not to those that are participating as private buyers or sellers. Nothing in the U.S. Constitution or in the Commerce Clause prohibits a State from eliminating private markets, thus creating a government monopoly (although in the latter case antitrust laws are applicable.)

If State and local governments are regulating (directly or indirectly) interstate markets, such regulations are subject to judicial analysis under the Commerce Clause. First, the judicial body must determine whether the regulations discriminate against out-of-State economic interests. If so, the regulating authority must demonstrate that the benefits to local interests outweigh the discriminatory effects and that no nondiscriminatory alternative is available to protect those interests. This test is difficult to pass. If the regulation does not discriminate against interstate commerce, it still must pass the "undue burden" test. Even if a regulation treats in-State and out-of-State interests in the same way, a statute has been held to be unconstitutional if it creates an undue burden on interstate commerce. ${ }^{152}$

The strictures of the Commerce Clause are not absolute; Congress, by using its powers to regulate interstate commerce, may authorize through legislation particular activities that may otherwise be viewed as unduly discriminating against or burdening interstate commerce. Various bills have been contemplated in the U.S. Congress. For example in May 1995, the full U.S. Senate passed S. 534, which would have authorized States to

${ }^{152}$ National Solid Wastes Management Association v. Myer, 63 F. 3d .652 \& 7th Cir. (1995). 
direct or limit waste flows under certain circumstances. The provisions of the bill were also added as an amendment to the 1997 Senate Energy and Water Appropriations Bill, but the amendment was removed in the final form of the legislation.

\section{Key Recent Court Cases}

Since the Carbone decision, lower courts have applied and expanded the interpretation of the Supreme Court in several key cases.

\section{Smithtown Case}

The municipality of Smithtown, New York, ${ }^{153}$ partially in response to Federa ${ }^{154}$ and State ${ }^{155}$ policies and statutes to protect the environment, initiated negotiations with the neighboring municipality of Huntington to provide joint waste disposal operations. Under a State-sanctioned agreement, ${ }^{156}$ Smithtown would provide the landfill and Huntington would provide the incinerator.

The construction of the incinerator was financed with tax-free bonds. The bonding authority, the New York State Environmental Facilities Corporation, loaned the funds to Ogden Martin to build the facility. The bonds were secured with a contractual obligation between Ogden and the two towns to reimburse Ogden over a 25-year period for the total costs (capital and operating) of the incinerator; this is known as a "service fee" and must be paid regardless of the amount of waste delivered to the facility. Ogden then pays the State bonding authority, which in turn pays the bondholders. The towns fund the "service fee" with property taxes and tipping fees. A flow control ordinance was enacted to ensure a steady flow of tipping fees. No tipping fee was charged for recyclables delivered to an adjacent facility, thus encouraging waste haulers to divert waste out of the waste stream to recycling. Violation of the flow control ordinance is punishable by a fine up to $\$ 500$ and up to 60 days in jail.

Smithtown solicited competitive bids to provide municipal garbage collection and disposal. All bidders were required to dispose of all residential garbage at the Huntington incinerator, where a $\$ 65$ per ton tipping fee was applicable. Most of the residential contracts were awarded to SSC Corp., whose total bid was $\$ 218$ per household in 1994. The $\$ 218$ was determined by converting the $\$ 65$ tipping fee at the incinerator into a $\$ 92$ charge per household and combining it with a collection charge of $\$ 126$ dollars per household. The total $\$ 218$ user fee was added to each homeowner's annual property tax.

In April 1994, Smithtown accused SSC of breach of contract because they were allegedly disposing of waste at facilities cheaper than Huntington and pocketing the savings. Smithtown, therefore, withheld funds from SSC, which sued in the U.S. District Court for the Eastern District of New York. SSC only contested the part of the contract that required waste to be delivered to a designated facility. The District Court found that both the flow control ordinance and the waste disposal contract with SSC impermissibly discriminated against interstate commerce, in violation of the Commerce Clause.

Smithtown appealed the decision in the U.S. Court of Appeals for the Second Circuit. The first order of business of the court was to determine whether Smithtown's flow control ordinance was a "regulation" subject to scrutiny under the Commerce Clause or merely the result of "participation" in the waste disposal business. SSC argued that the ordinance constituted an exercise of the town's "sovereign powers of civil and criminal enforcement." Smithtown countered that it was a participant in the waste disposal business because it had placed substantial public funds at risk in financing the incinerator and the ordinance protected that investment. Since the ordinance threatened violators with fines and jail terms, the Court of Appeals ruled that Smithtown was acting as a regulator and did not warrant an exception to the Commerce Clause.

Citing Carbone as precedent, the Court of Appeals reinforced the decision of the District Court and ruled that Smithtown's flow control ordinance was unconstitutional. The Court of Appeals found that the ordinance discriminated against interstate trade since it directed all waste to a single facility, excluding in-State and outof-State competitors. Furthermore, Smithtown failed to demonstrate that it had no other means available to support a legitimate local interest. As in the Carbone case, Smithtown could use economic flow control alternatives, such as property taxes, to recover funds to pay the service fee for the incinerator.

\footnotetext{
${ }^{153}$ SSC Corporation v. Town of Smithtown, 66 F. 3d 502, 2d Cir. (1995); Cert. Denied 116 S. Ct. 911 (1996).

${ }^{154}$ The Resource Conservation and Recovery Act of 1976 (RCRA), Public Law No. 94-580, 42 U.S.C., $\$ \$ 6901-6902$, requires all solid waste to be either "utilized for resource recovery" or "disposed of in sanitary landfills" in accordance with U.S. Environmental Protection Agency Standards 42 U.S.C. § 6943(a)(2) (1988) and Part 258 of 40 C.F.R. (1994).

155"The Long Island Landfill Law," 1983 N.Y. Laws 299, N.Y. Environmental Conservation Law, § 27-0704 (1984).

${ }^{156}$ In December 1989, the towns of Smithtown and Huntington executed a Municipal Cooperation Agreement under Article 5G of the General Municipal Law of the State of New York. See N.Y. General Municipal Law, §§ 119-m to -00 (1986 \& Supp. 1994$)$.
} 
On the other hand, the Court of Appeals reversed the District Court decision by ruling that the Smithtown contract with SSC constituted municipal "participation" rather than "regulation" and, hence, was not subject to Commerce Clause scrutiny. Courts have consistently ruled that nothing in the Commerce Clause prohibits a State from participating in the marketplace and favoring its own citizens over the citizens of other States. ${ }^{157}$ The Court determined that Smithtown was a market participant in two distinct forms of market activity: "waste collection" and "waste disposal." Smithtown is using tax dollars to pay for these services. The services are contracted out but could have been done with goverrment workers. Smithtown is a "buyer" rather than a "regulator" of waste services. The Supreme Court permits municipalities to discriminate in favor of their own taxpayers when buying or selling services in the marketplace.

There are several reasons why Smithtown charges SSC tipping fees and then reimburses SSC, rather than paying the fees directly to Ogden:

1. Tipping fees control the otherwise free flow of waste from other sources.

2. Tipping fees encourage recycling because there is no tipping for recycled waste.

3. Tipping fees encourage prospective contract bidders to forecast accurately the amount of waste from each area. Underestimation results in unreimbursed tipping fees.

4. By itemizing disposal costs in the contract, Smithtown can easily modify fees to residents as tipping fees change.

Clearly, the characteristics of the contract enhance the town's ability to monitor the contract and minimize costs to residents. The fact that SSC actually pays the tipping fees to Ogden must not cloud the fact that Smithtown is the consumer and ultimate payor for those services.

In summary, the Court of Appeals for the Second Circuit found Smithtown to be acting as a market participant because it was spending its own funds to enter the market as a "buyer" and "consumer" (rather than a regulator) of waste disposal services. The court reasoned that Smithtown was buying services similarly to any local government buying educational or police protection services. In all these instances, the benefits are restricted to those that fund the treasury by paying taxes or fees. Therefore, as a buyer of services from the waste haulers, the town can dictate by contract where the waste is to be delivered.

\section{Babylon Case}

In 1983 the New York legislature required Babylon, as well as other towns in its jurisdiction, to close municipal dumps in the interest of the environment. ${ }^{158}$ Consistent with State policy preferences, ${ }^{159}$ Babylon initiated action to construct an incinerator. After a competitive bidding process, a contract was awarded to Ogden Martin to construct the facility. The town, in accordance with New York law, created an Industrial Development Agency to issue tax-exempt bonds, own the incinerator and lease it to Ogden. The land on which the incinerator was built was owned by the town, leased to the Industrial Development Agency, and sublet to Ogden.

In accordance with a service agreement, the town had an unconditional commitment to pay Ogden a service fee covering the total capital and operating costs of the facility. The town retained exclusive rights to control the flow of garbage and tipping fees at the incinerator. In order to secure a waste stream to ensure the financial viability of the facility, the town instituted a flow control ordinance.

Babylon discontinued the enforcement of its flow control ordinance after the Carbone decision struck down a similar ordinance. As an alternative, the town created a commercial garbage collection district to displace private collectors with a single hauler, BSSCI, which was chosen through a competitive bidding process. BSSCI was paid to collect and dump trash at the incinerator, where there was no tipping fee unless the tonnage exceeded a certain amount. The disposal system was financed with property taxes and user fees on the generators of the waste.

Potential competitors challenged Babylon's waste management system in the U.S. District Court for the Eastern District of New York under the Commerce Clause and antitrust laws. Central to the legal dispute was the relationship between the town, BSSCI, and the incinerator. The District Court granted a preliminary injunction despite its own finding that no irreparable injury had been demonstrated. However, the District Court concluded that Babylon's amended ordinance

${ }^{157}$ Hughes v. Oklahoma, supra at 810; LeFrancois v. Rhode Island, 669 F. Supp. 1204, D.R.I. (1987); Evergreen Waste Sys. V. Metrop. Sero. Dist., 643 F. Supp. 127, D. Or. (1986); Affd on Other Grounds, 820 F. 2d 1482 (1987); Shayne Bros., Inc. v. Dist. of Columbia, 592 F. Supp. 1128, D.D.C. (1984); County Comm'rs of Charles County v. Stevens, 299 Md. 203, 473 F. 2d 12 (1984).

${ }^{158} 1983$ N.Y. Laws 299, codified at N.Y. Environmental Conservation Law, § 27-0704 (1984).

${ }^{159}$ N.Y. Environmental Conservation Law, § 27-0106 (Supp. 1995). 
had the same discriminatory effect on interstate commerce as the ordinance struck down in the Carbone decision.

Babylon and BSSCI appealed the decision to the Court of Appeals for the Second Circuit. Potential competitors maintained their claim that exclusion from the waste market discriminated against interstate commerce because it granted the entire waste disposal business to a single hauler and a single incinerator eliminating competition from other in-State and out-of-State companies. Babylon countered by arguing that the town was not subject to the scrutiny of the Commerce Clause because it was a market participant rather than a market regulator. Further, even if the town was considered a market regulator, its waste disposal system did not discriminate in favor of any local company, but evenhandedly prohibited any local or out-of-State companies other than the designated agents BSSCI and Ogden from entering their waste disposal market. Finally, Babylon argued that its waste disposal scheme did not place an undue burden on interstate commerce.

The Court of Appeals found that Babylon was a market regulator and, therefore, subject to the tests of the Commerce Clause. Although Babylon was a market participant in one respect (it bought garbage hauling services from BSSCI), it did not enjoy carte blanche to regulate a market (in other areas) just because it happened also to be a participant in that market. The legality of each challenged activity must be evaluated separately. The court also found that, although Babylon eliminated the commercial waste market, it did not in any way discriminate (favor in-State companies over out-of-State companies) against interstate commerce.

The Babylon case differs from the Carbone case, in which the flow control ordinances required local garbage haulers to buy disposal services from a local facility. In Babylon, the market was eliminated, with the local government providing services to those within its jurisdiction rather than as a business selling to a captive consumer group. Having found that Babylon's waste system did not discriminate against interstate trade, the Court's next step was to follow Supreme Court guidance $^{160}$ and apply the undue burden test. ${ }^{161}$ The Court concluded that hiring a single contractor to handle the town's waste did not necessarily affect interstate commerce, particularly since out-of-State bidders and in-State bidders had equal opportunity to bid on and be awarded the contract. Moreover, the Court held that the taxes Babylon used were in reality a purchase of services from the private businesses providing them rather than a subsidy. The town was in fact using economic flow control, buying incineration services in the market with tax dollars and guaranteeing a flow of garbage to the incinerator by reducing its tipping fees to zero, to the best interest of the community.

\section{Other Rulings}

In Harvey \& Harvey v. County of Chester, PA, and TriCounty Industries, Inc. v. County of Mercer, PA, just one month after the Second Circuit Court's decisions in Smithtown and Babylon, the Third Circuit Court set forth new criteria in the determination whether flow control laws violated interstate commerce. The court's emphasis was on the fairness and openness of the decisionmaking process leading to the selection of the hauler or disposal site, rather than determining any given designation's impact on interstate commerce. This shift in focus to the fairness of the selection process could result in many flow control ordinances being upheld. At least municipal flow control ordinances are not likely to be declared to discriminate against interstate commerce if out-of-State parties have a fair and open opportunity to compete for the contracts.

\section{Antitrust Considerations}

Flow control is also subject to antitrust laws. However, local governments are deemed to be immune from antitrust liability under the "State action" doctrine, provided that their anticompetitive policies and practices are clearly authorized by policies adopted by the State legislatures. ${ }^{162}$ When private parties are involved, the State action doctrine requires active supervision by the State in addition to a clearly articulated State policy. ${ }^{163}$

If local governments are acting as market participants rather than market regulators, it is uncertain whether they can be entitled to immunity from antitrust laws under the State action doctrine. The precise application of State action immunity to local governments acting as market participants is entangled in issues of fact and law and may have to be resolved on a case-by-case basis.

\footnotetext{
${ }^{160}$ Pike v. Bruce Church, Inc., 397 U.S. 137, 25 L. Ed., 2d 174, 90 S. Ct. 844 (1970).

${ }^{161}$ The guidance is as follows: "... where a statute regulates even-handedly to effectuate a legitimate local public interest, and its effects on interstate commerce are only incidental, it will be upheld unless the burden imposed on such commerce is clearly excessive in relation to the putative local benefits." Source: USA Recycling Inc. v. Town of Babylon, 66 F. 3d 1272, 1995 U.S. App. (Lexis 27011$)$; 41 ERC (BNA) 1254; 25 ELR 21522; p. 28.

${ }^{162}$ Hallie v. Eau Claire, 471 U.S. 34 (1985).

${ }^{163}$ Hallie v. Eau Clair, 471 U.S. at 47.
} 


\section{Summary}

Municipalities that continue to enforce legislative flow control may be subject to damage suits and litigation. However, the Smithtown, Babylon, Harvey, and TriCounty decisions provide paths for legitimizing flow control despite the Carbone decision. Nothing in the Commerce Clause, or for that matter in the Constitution, prohibits a State from eliminating private markets and substituting a government monopoly. The judicial systems currently upholds such municipalization of waste disposal services, particularly if the activities are contracted out through competitive bidding in which out-of-State parties are given fair and equal opportunities to compete.

\section{Financial Impacts of Recent Judicial Decisions}

\section{Bond Market}

As a result of the Supreme Court decisions that outlawed the waste disposal practices of many municipalities, Moody's Investors Service undertook a case-bycase assessment of ratings of 76 solid waste bonds. ${ }^{164}$ The assessments examined credit fundamentals (including the economy, finances, administration, and debt) and the potential credit risks for solid waste bondholders, given that waste systems must operate in a free market environment with waste streams evolving to the cheapest disposal method. Moody's criteria for the credit assessments did not assume blanket absence of legal flow control; downgrades were limited to those systems that had already experienced material losses, such as declines in waste streams or financial deterioration, or were currently involved in litigation. Moody's key findings were as follows:

- Fourteen ratings were downgraded;Moody cited reductions in waste streams, financial deterioration, and litigation as the contributing factors to the downgrades.

- Continued deterioration of the financial credibility of the waste systems was likely without a Federal solution that protected or grandfathered legal flow control.

- Moody indicated that the ratings would be raised if Congress authorized legal flow control.

- In cases where waste streams were competitive, financial flexibility and managerial responsiveness were key factors in weighing creditworthiness.

- The successful substitution of economic flow control for legal flow control was viewed as an increasingly important factor in credit determination.

\section{The Role of Competition and Absence of Adequate Flow Control in Bond Rating Downgrades}

\section{Legal Security-No Cure-All for Loss of Waste and Declining System Revenues}

A deficiency makeup of system revenues or even a general obligation guarantee of debt service does not automatically mean that credit quality would be unaffected by the substantial weakening of a solid waste enterprise. The timing and sufficiency of the guarantee and the ability of the obligor to fulfill the backup commitment must also be considered.

For example, in New York State, the rating of St. Lawrence County's Solid Waste Management Authority was downgraded from Baa to Ba (see Appendix G for definitions of ratings) as a result of a diversion of waste attributable to a noncompetitive tipping fee. This bond had a double-barreled security. As the enterprise weakened, bondholder security shifted from system revenues to the county's contractual obligation under a service agreement. The county's general obligation bond rating is Baa. Although it appears that the county possesses the resources to meet the commitment to pay debt service on the solid waste bonds, the subsidy still must be budgeted and implemented on a timely basis. The distinction between the county's rating and the authority's rating stems from the loss of waste and projected drawdown of enterprise cash reserves as well as the contractual obligation of the county, which is considered weaker than the county's general obligation, unlimited tax security.

Declining Waste Levels and Weakened Financials Prompt Downgrade

Declining waste levels and weakened financial operations were cited as the major factors in the downgrade of the Prince George's County (Maryland) Solid Waste

(Continued on page 95)

\footnotetext{
${ }^{164}$ Moody's Investors Service, Moody's Municipal Credit Report, Moody's Solid Waste Rating Surveillance and Rating Outlook (New York, NY, May 1995).
} 


\section{Interstate Movement of Waste}

Before the Supreme Court's decisions that prohibited States from closing their borders to waste from other States, the disposal of municipal solid waste, in most States, generally occurred near its geographic point of origin. To the extent that waste crossed State lines, a good portion of it usually traveled only a few miles to natural waste disposal sites. This practice reflects a cooperative and collective strategy of individuals in a community to solve their common waste problems. The fact that the waste crossed State lines may have been coincidental; the overall objective of the communities was to dispose of their waste in the most efficient, environmentally sound, and cost-effective manner.

\section{The Role of Competition and Absence of Adequate Flow Control in Bond Rating Downgrades (Continued)}

Management System from A to Baal. This rating action was based on loss of waste and a weakened financial position, despite the county's legal pledge to use General Fund resources or other available funds to pay operating costs if system revenues proved insufficient. Prince George's County's general obligation rating is Aa.

The rating distinction here reflects the weakening of the system and the fact that the timing and extent of a county subsidy were not clearly delineated under county deficiency makeup covenants, leaving unanswered questions about when necessary revenues would be transferred. Prince George's County's General Fund operations are also under increased financial pressures that have no relation to the solid waste system.

Financial Flexibility-A Key Element in Measuring Degrees of Risk

The Economic Development Authority of Fairfax, Virginia, and Southeastern Public Service Authority (SPSA) both experienced declines in waste flows. The ratings on these issuers were lowered to $\mathrm{Al}$ and $\mathrm{Baal}$, respectively, from $\mathbf{A a}$ and $\mathbf{A}$, representing increased risk in implementing a business plan to promote competition. The effect of a loss of waste on revenues is expected to be tempered by management responses, such as subsidizing commercial fees and aggressively pursuing alternative waste streams.

While the uncertainty of successful implementation is reflected in the rating downgrades, Moody's views positively the ability of both systems to adjust pricing or attract alternative waste sources. By contrast, this flexibility is not immediately practicable for most of the New Jersey systems, which have higher overhead and extremely noncompetitive tipping fees to adjust. Tipping fees for New Jersey systems affected by the rating downgrades average about $\$ 110$ per ton. SPSA is expected to increase its residential fee from $\$ 34$ per ton to $\$ 63$ per ton while lowering the fee for the more vulnerable commercial waste to between $\$ 30$ and $\$ 34$ per ton from $\$ 41$ per ton. The Fairfax tipping fee is still fairly competitive at $\$ 48$ per ton. Fairfax is taking steps to increase its waste volume by pursuing out-ofcounty waste.

Financial Position Weakened, but Responsiveness Reflected in Credit Standing

Moody's considers Lancaster, Pennsylvania, to be an interesting case study. In this situation, management's responsiveness had a favorable effect on the assigned rating because it prevented the situation from worsening. As a result of a decline in revenues and credit risks tied to the resolution of the flow control issue, Moody's downgraded the authority's credit rating from $\mathrm{Al}$ to $\mathrm{A}$.

At the same time, Moody's noted management's proactive approach to the risk of losing flow control. Management lowered tipping fees to attract more waste to the facility. This strategy has only been partially successful, because waste volume has not increased to a level that, given the lower price now charged at the gate, balances out lower costs with increased volume. While Moody's considers the Lancaster management strategy commendable, the system still carries risks that are reflected in the lower rating and unfavorable outlook.

Source: Moody's Investor Service, Moody's Municipal Credit Report, Moody's Solid Waste Rating Surveillance and Rating Outlook (New York, NY, May 1995), pp. 3-4. 


\section{Public Officials Around the Country Encounter Problems}

- Dade County, Florida, lowered disposal fees by more than 20 percent, fired 280 employees, renegotiated contracts, restructured debt, sharply reduced capital expenditures, increased the taxpayer surcharge on water and sewer bills by 12 percent, increased the cost of carting services, cut recycling efforts, delayed development of two household chemical collection facilities, downsized the illegal dumping task force, and cut the county's mulching program. Despite Dade County's significant reduction in tipping fees, cost savings, and revenue enhancements, the County's bond rating was lowered by national rating companies.

- Virginia's Southeastern Public Service Authority (SPSA) lost more than 50 percent of its general cash balance, fired 50 employees, increased the user fee for disposal, and instituted a new fee for recycling. SPSA's bonds were downgraded due to lack of flow control.

- Hennepin County, Minnesota, faces more than $\$ 300$ million in court-imposed judgments stemming from a lawsuit challenging the County's flow control authority. Taxes could more than double to cover the County's liability.

- Atlantic County and surrounding counties in New Jersey lost more than $\$ 2$ million in revenues. Staff was cut by 8 percent. Development of a recycling center stopped. Bonds used to finance solid waste facilities and services have been downgraded.

- Iredell County, North Carolina, has lost nearly $\$ 300,000$ in cash revenues.

- New Hanover County, North Carolina, stopped development of a recycling facility and raised taxes while transferring nearly $\$ 10.5$ million from general funds to cover the more than $\$ 18$ million in lost revenues.

- Lee County, Florida, increased property taxes on an emergency basis to cover $\$ 7.8$ million in lost revenues, representing 30 percent of its solid waste departments's operating budget. Property owners face a special assessment in the long term.

- The Town of Babylon, New York, lost $\$ 2$ million in 1995 alone- 6 percent of its total town budget. The town was forced to lay off 70 employees. Babylon created a commercial garbage district to offset its losses and was sued by haulers. The lawsuit cost the town nearly $\$ 5$ million in lost revenues and legal expenses.

- The bond rating of the solid waste authority of St. Lawrence County, New York, was lowered because the authority faces a $\$ 1$ million shortfall this year. The county will need to borrow up to $\$ 3$ million to subsidize the authority.

- Charles County, Maryland, lost 40 percent of its facility revenues, fired employees, and cut recycling efforts. It faces the potential of having to subsidize its landfill with tax revenues.

- Calvert County, Maryland, cut recycling efforts and employee hours by 30 percent to avoid layoffs due to lost revenues.

- Citrus County, Florida, delayed capital expenditures as it faces loosing up to 60 percent of its waste stream to out-of-county landfills.

- St. Lucie County, Florida, lost 30 percent of its landfill revenues and fired 11 employees.

- Dutchess County, New York, taxpayers paid \$5 million more in property taxes in the last yearand-a-half in addition to their garbage bills due to the loss of waste volume.

- Seven metropolitan Minnesota counties have seen a reversal in recycling amounts and an increased reliance on landfills. After a decade of progress in diverting waste from landfills by use of recycling and resource recovery facilities, from a 1993 landfilling rate of 11 percent, the counties report that landfilling has reversed direction and is now over 18 percent.

- Oneida and Herkimer Counties in New York face a lawsuit threatening to scuttle the counties' integrated waste management system and force property taxpayers to pay off $\$ 47$ million in bonds.

- Nassau County, Florida, lost 20 percent of its facility revenues.

- Montgomery, Otsego, and Schoharie Counties in New York stopped recycling collection services and face dismantling the entire solid waste management system. The bond insurer for the counties' facilities stated that future actions "could totally destroy the established belief in the municipal bond market."

Source: National Association of Counties, "Think the Lack of Flow Control Hasn't Hurt Anybody? Think Again" (Washington, DC, January 1997). 
On the other hand, in States where landfill space is relatively scarce and expensive (New Jersey and New York), large quantities of waste may be shipped significant distances. In 1993, approximately 13 million tons of waste, or less than 5 percent of total U.S. solid waste, was exported. ${ }^{165}$ Over 40 percent of the total waste exported came from New Jersey and New York (Table 27). The key economic factors influencing the shipment of waste are the relative tipping fees of the exporting and importing geographic areas and transportation costs.

The political willingness of States to receive out-of-State waste has been a significant factor in the growth of long-distance waste disposal operations. As of 1993, 41 of the 48 contiguous States had enacted or contem- plated legislation restricting the flow of out-of-State waste into their jurisdictions. ${ }^{166}$ Over the years, many such laws have been challenged and struck down, but there is still much uncertainty associated with the development of long-distance waste disposal businesses. The two recent Supreme Court decisions (Gratiot and (Carbone) have done much to eliminate uncertainty. Large landfills that are intending to accept waste from faraway sources are beginning to be built. The landfills are ideally situated environmentally and geographically. Furthermore, it is likely that large landfills which will derive revenues from large geographic regions independent of State borders will be able efficiently to meet the environmental standards mandated by Subtitle $D$ regulations of the Resource Conservation and Recovery Act and the Clean Air Act.

Table 27. Waste Generated, Exported, and Imported by Trading Partners, 1993

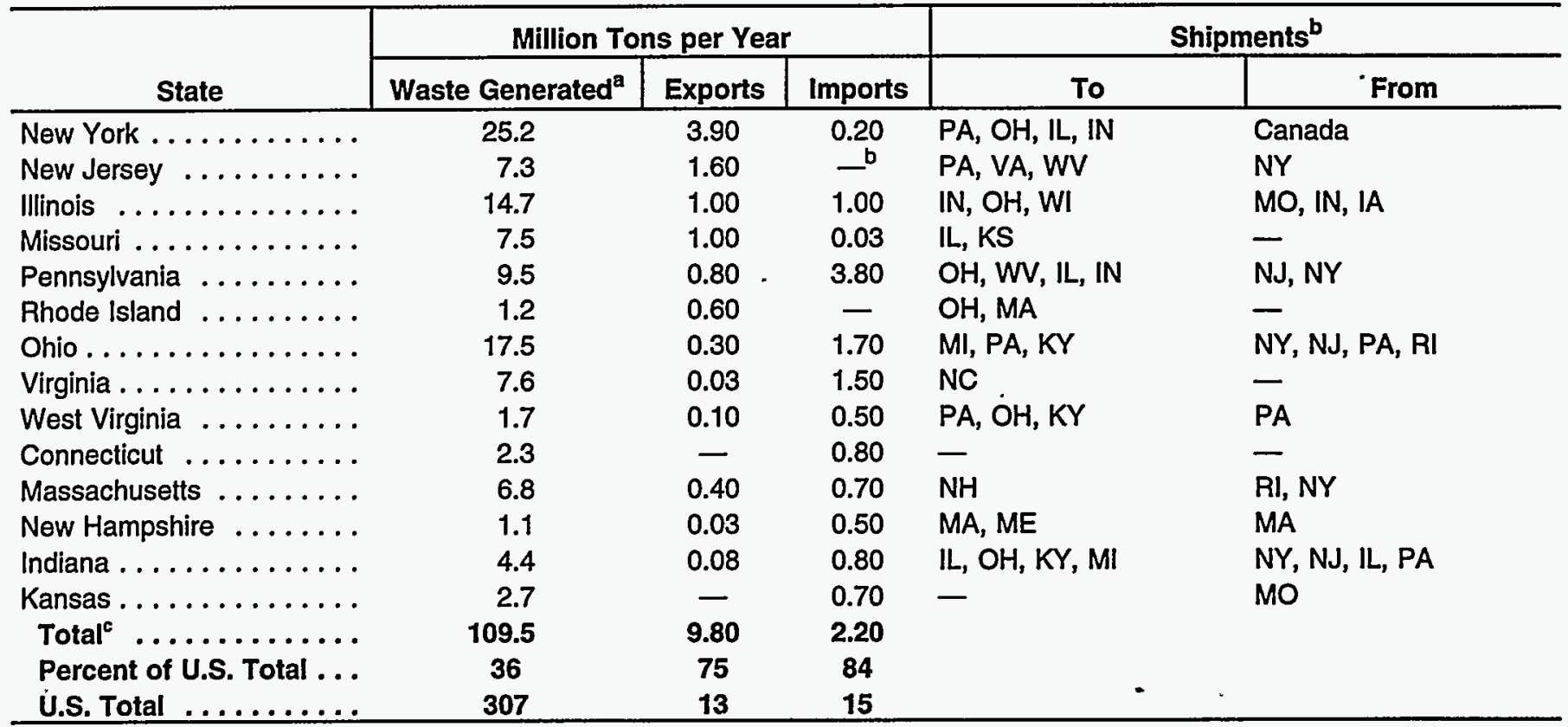

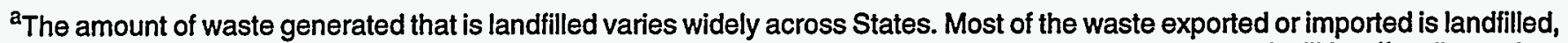
but there are exceptions. For example, in Connecticut about one-third of imports go to waste-to-energy facilities (for discussion, see J.E. McCarthy, Interstate Shipment of Municipal Solid Waste: 1995 Update, CRS Report for Congress, 95-570 ENR (Washington, DC: Congressional Research Service, 1995).

${ }^{b}$ Reflecting shortcomings in the available data, numbers for trading partners do not always match. For example, New Jersey reports receiving from New York, but New York does not report shipping to New Jersey.

${ }^{c}$ Exports and imports do not match for at least two reasons. One is that States in addition to those listed above export and import waste; the other is that even for nationwide data, reported exports and imports do not match (see bottom line above).

Sources: Waste Generated: Biocycle, Vol. 35, No. 4 (April 1994), p. 48. Exports and Imports: J.E. McCarthy, Interstate Shipment of Municipal Solid Waste: 1995 Update, CRS Report for Congress, 95-570 ENR (Washington, DC: Congressional Research Service, 1995). Shipments: J.E. McCarthy (1995) and E. Ley, M.K. Macaulry, and S.W. Salant, "Spatially and Intertemporally Efficient Waste Management: The Costs of Interstate Flow Control," Discussion Paper 96-23 (Washington, DC: Resources for the Future, 1996).

\footnotetext{
${ }^{165}$ These waste figures include significant quantities of waste such as construction debris that are not included in the Environmental Protection Agency's definition of municipal solid waste. However, these figures can be used to estimate the amount of waste that crosses State lines, municipal or total waste.

${ }^{166}$ E. Ley, M.K. Macauley, and S.W. Salant, "Spatially and Intertemporally Efficient Waste Management: The Costs of Interstate Flow Control" (Washington, DC: Resources for the Future, June 1996), p. 4.
} 



\section{Growth of the Landfill Gas Industry}

This chapter discusses the development of the landfill gas industry and assesses its prospects for expansion. It describes the regulations that affect the landfill gas industry; provides information on U.S. Environmental Protection Agency (EPA) efforts to encourage the conversion of landfill gas (LFG) emissions into energy; provides information on the economics of LFG conversion into energy; and provides information on the impact of new environmental regulations.

\section{Municipal Solid Waste Landfills, Landfill Gas, and Control Systems}

Each person in the United States generates about 4.5 pounds of waste per day, or almost 1 ton per year, most of which is deposited in municipal solid waste (MSW) landfills. ${ }^{167}$ As MSW decomposes, it produces a blend of several gases, including methane (about 50 percent). Table 28 shows the main constituents of LFG and their proportions. Methane $\left(\mathrm{CH}_{4}\right)$ is a greenhouse gas and also poses explosion hazards if uncontrolled. On the other hand, it is the main component of natural gas and can be a valuable source of energy. Other LFG constituents, such as nonmethane organic compounds (NMOCs), can contribute to the formation of smog. Others pose health hazards due to their toxicity.

Gas collection systems operate continuously. They usually consist of vertical wells and sometimes horizontal trenches or other zones filled with permeable material within the waste, from which LFG is extracted by application of a vacuum. Once the gas is withdrawn, it can be flared ${ }^{168}$ or processed.

\section{Development of the Landfill Gas Industry}

The first commercial gas energy recovery project was at the Palos Verdes Landfill, in Rolling Hills, California, in 1975. ${ }^{169}$ The project converted LFG to pipeline-quality gas that was sold to the Southern California Gas Company. Several other projects to convert LFG to pipelinequality gas were started in the late 1970s in California, including Mountain View in 1978 and Monterey Park in 1979. The first direct heating boiler projects were brought on line in the late 1970s and early 1980s. The first electricity generation projects took place at Brattleboro, Vermont, in 1982. Most projects are located in California and the Northeast.

\section{LFG Utilization Applications}

There are five main ways to recover energy from LFG: direct heating, electricity generation, chemical feedstock, purification to pipeline-quality gas, and heat recovery. Each of these methods has a variety of LFG applications. A complete list of applications and technologies is provided below.

1. Direct Heating Applications:

- Use for industrial boilers

- Space heating and cnoling

- Industrial heating/cofiring.

2. Electricity Generation Applications:

- Processing and use in reciprocating internal combustion (RIC) engines (i.e., stoichiometric combustion or lean combustion)

- Processing and use in gas and steam turbines

- Processing and use in fuel cells.

3. Feedstock in Chemical Manufacturing Processes: - Conversion to methanol (and optional subsequent industrial or vehicular fuel use)

- Conversion to diesel fuel (and subsequent use as vehicular fuel).

4. Purification to Pipeline-Quality Gas:

- Utilization as vehicular fuel

- Incorporation into local natural gas network.

5. Heat-Recovery from Landfill Flares:

- Using organic Rankine cycle

- Using Stirling cycle engines.

${ }^{167}$ U.S. Environmental Protection Agency, Landfill Methane Outreach Program, EPA-430-F-95-068A (Washington, DC, April 1995).

168 "Flaring" is combustion of gas to avoid unsafe accumulation.

${ }^{169}$ Most of the information in this section was obtained from M. Doorn, J. Pacey, and D. Augenstein, Landfill Gas Energy Utilization Experience: Discussion of Technical and Non-Technical Issues, Solutions, and Trends, EPA-600/R-95-035, prepared by E.H. Pechan and Associates, Inc., for the Air and Energy Engineering Research Laboratory, U.S. Environmental Protection Agency (Washington, DC, March 1995). 


\begin{tabular}{|c|c|c|}
\hline Constituent Gas & \multicolumn{2}{|c|}{ Concentration in LFG } \\
\hline$\ldots \ldots \ldots \ldots$ & 35 to 60 percent & 50 percent \\
\hline Carbon Dioxide $\left(\mathrm{CO}_{2}\right)$ & 35 to 55 percent & 45 percent \\
\hline Nitrogen $\left(\mathrm{N}_{2}\right) \ldots \ldots \ldots \ldots \ldots \ldots \ldots \ldots \ldots \ldots$ & 0 to 20 percent & 5 percent \\
\hline Oxygen $\left(\mathrm{O}_{2}\right) \ldots \ldots \ldots \ldots \ldots \ldots \ldots \ldots \ldots \ldots \ldots \ldots \ldots \ldots \ldots$ & 0 to 2.5 percent & $<1$ percent \\
\hline Water Vapor $\left(\mathrm{H}_{2} \mathrm{O}\right)$ & 1 to 10 percent & NA \\
\hline Nonmethane Organic Compounds (NMOCs) . . . . . . . . . & 237 to $14,294 \mathrm{ppmv}$ & 2,700 ppmv \\
\hline
\end{tabular}

$N A=$ not available. ppmv $=$ parts per million by volume.

Note: Highest values occur in perimeter wells.

Sources: G.J. Sandelli, Demonstration of Fuel Cells To Recover Energy from Landfill Gas. Phase I Final Report: Conceptual Study, EPA-600-R-92-007, prepared for the U.S. Environmental Protection Agency by International Fuel Cells Corporation (Washington, DC, January 1992); M. Doorn, J. Pacey, and D. Augenstein, Landfill Gas Energy Utilization Experience: Discussion of Technical and Non-Technical Issues, Solutions, and Trends, EPA-600/R-95-035, prepared for the Air and Energy Engineering Research Laboratory, U.S. Environmental Protection Agency by E.H. Pechan and Associates, Inc. (Washington, DC, March 1995).

\section{Recent Regulatory History}

This section reviews the most recent regulations that affect the LFG industry. Table 29 summarizes the regulations discussed in this section.

\section{Resource Conservation and Recovery Act (RCRA), Subtitle D}

\section{National Municipal Solid Waste Landfill Criteria}

The original regulations under Subtitle $\mathrm{D}$ of the Resource Conservation and Recovery Act of 1976 (RCRA), issued by EPA's Office of Solid Waste, covered the migration (via underground routes) and collection of explosive mixtures in buildings. A more stringent set of Subtitle D regulations was promulgated in the Federal Register on October 9, $1991 .{ }^{170}$ On that date, new standards were issued for all new MSW landfills that were receiving waste 2 years after the rule's publication in the Federal Register. ${ }^{171,172}$ Although the rule establishes minimum health and environmental protection standards, implementation of the regulations is left largely to the State governments. ${ }^{173}$ The regulations are intended as minimal national criteria to guide States in establishing and enforcing their own regulations, which must be reviewed and approved by the EPA. $^{174}$

Specific applicability criteria are as follows:

1. All new MSW landfills that were receiving waste 2 years after October 9, 1991, must comply fully with the RCRA.

2. For landfills that stopped taking in waste between October 9, 1991, and October 9, 1993, only compliance with final cover requirements is necessary.

3. The standards do not apply to landfills that stopped operating prior to October 9, 1991.

The regulations established comprehensive protective standards in six categories of MSW landfill management:

1. Location restrictions

2. Operating requirements

3. Design standards

4. Groundwater monitoring and corrective action

5. Closure and postclosure care

6. Financial assurance.

\footnotetext{
${ }^{170}$ R. Woods, “Building a Better Liner System," Waste Age (March 1992), p. 26.

${ }^{171}$ In July 1993, the EPA provided some extensions to the effective date of the standards for existing, smaller landfills. In addition, financial assurance and closure requirements for all existing landfills were delayed for 1 year.

${ }^{172}$ S.M. Roe, P.G. Fields, and R.E. Coad, Methodologies for Quantifying Pollution Prevention Benefits from Landfill Gas Control and Utilization, EPA-600/R-95-089, prepared by E.H. Pechan \& Associates, Inc., for the U.S. Environmental Protection Agency (Washington, DC, July 1995).

${ }^{173}$ U.S. Environmental Protection Agency, Criteria for Solid Waste Disposal Facilities: A Guide for Owners/Operators, EPA/530-SW-91-089 (Washington, DC, March 1993).

${ }^{174}$ U.S. Environmental Protection Agency, Safer Disposal for Solid Waste: The Federal Regulations for Landfills, EPA/530-SW-91-092 (Washington, DC, March 1993).
} 
Table 29. Regulatory Milestones Affecting the Landfill Gas Industry, 1976-1996

\begin{tabular}{|c|c|c|}
\hline Agency, Date & Milestone/Regulation & Effect \\
\hline FERC, 1978 & $\begin{array}{l}\text { Public Utility Regulatory Policies } \\
\text { Act of } 1978 \text { (PURPA) }\end{array}$ & $\begin{array}{l}\text { Requires utilities to interconnect with small power producers (SPP), } \\
\text { including LFG energy recovery projects, and purchase the energy at } \\
\text { the utilities' avoided costs. }\end{array}$ \\
\hline EPA, 1991 & $\begin{array}{l}\text { Promulgation of new landfill } \\
\text { regulations under Subtitle D, } \\
\text { RCRA, setting standards in six } \\
\text { categories: location restrictions, } \\
\text { operating requirements, design } \\
\text { standards, groundwater monitoring } \\
\text { and corrective action, closure and } \\
\text { postclosure care, and financial } \\
\text { assurance }\end{array}$ & $\begin{array}{l}\text { Depending on timing of implementation (see below). Once } \\
\text { implemented: strengthen existing regulations; increase safety and } \\
\text { reduce environmental impact; and, indirectly, increase costs of } \\
\text { compliance for landfill operators. }\end{array}$ \\
\hline EPA, 1991 & $\begin{array}{l}\text { Proposed New Source } \\
\text { Performance Standards (NSPS) } \\
\text { under Section } 111(\mathrm{~b}) \text { and } \\
\text { Emissions Guidelines under } \\
\text { Section } 111 \text { (d) of the Clean Air Act } \\
\text { (CAA) }\end{array}$ & $\begin{array}{l}\text { The NSPS for MSW landfills designate LFG emissions as a pollutant. } \\
\text { The proposed emissions guidelines call for control of LFG emissions } \\
\text { through installation and maintenance of LFG control systems at MSW } \\
\text { landfills with capacity in excess of } 167,000 \text { tons. The EPA estimated } \\
\text { in } 1992 \text { that } 621 \text { landfills would be required to install collection/control } \\
\text { systems when the regulations were implemented. }\end{array}$ \\
\hline EPA, 1993 & $\begin{array}{l}\text { One- and two-year extensions of } \\
\text { some effective dates in Federal } \\
\text { landfill regulations under Subtitle D, } \\
\text { RCRA }\end{array}$ & $\begin{array}{l}\text { Implementation schedule delay; allowed more time for small and other } \\
\text { special case landfills to either comply with regulations for operating } \\
\text { landfills or shut down. }\end{array}$ \\
\hline EPA, 1994-1995 & $\begin{array}{l}\text { Effective dates for compliance with } \\
\text { applicable CAA and Clean Water } \\
\text { Act regulations under RCRA }\end{array}$ & $\begin{array}{l}\text { RCRA requires compliance with applicable CAA and Clean Water Act } \\
\text { regulations, such as restrictions on primary and byproduct emissions } \\
\text { (i.e., } \mathrm{NO}_{\mathrm{x}} \text { and } \mathrm{CO} \text { ) in ozone nonattainment regions. Encourages the } \\
\text { use of } \mathrm{LFG} \text { control systems, but sometimes discourages the use of } \\
\text { energy recovery systems. }\end{array}$ \\
\hline EPA, 1994 & $\begin{array}{l}\text { Proposed revisions to some CAA } \\
\text { regulations that apply to new and } \\
\text { existing landfills, including } \\
\text { renewable energy reserve credits } \\
\text { (Title IV of CAA Acid Rain } \\
\text { Program) (see below) }\end{array}$ & $\begin{array}{l}\text { Strict LFG toxic and greenhouse constituent gas control through } \\
\text { collection systems. Renewable energy reserve credits encourage LFG } \\
\text { energy recovery once LFG is collected (see below). }\end{array}$ \\
\hline
\end{tabular}

See notes at end of table. 
Table 29. Regulatory Milestones Affecting the Landfill Gas Industry, 1976-1996 (Continued)

\begin{tabular}{|c|c|c|}
\hline Agency, Date & Milestone/Regulation & Effect \\
\hline FERC, 1995 & $\begin{array}{l}\text { Federal Energy Regulatory } \\
\text { Commission (FERC) rejection of } \\
\text { the component of California's } \\
\text { Biennial Resource Plan Update } \\
\text { that restricted bidding for wholesale } \\
\text { power to qualifying facilities (QFs) }\end{array}$ & $\begin{array}{l}\text { States may not assign a preference to bidding for energy sources } \\
\text { under PURPA. States may not assign externality benefits to particular } \\
\text { technologies. }\end{array}$ \\
\hline EPA, 1996 & $\begin{array}{l}\text { Final regulation under the CAA } \\
\text { establishing standards for new and } \\
\text { guidelines for existing large MSW } \\
\text { landfills }\end{array}$ & $\begin{array}{l}\text { Requires landfills that emit LFG in excess of } 50 \text { megagrams (Mg) per } \\
\text { year to control emissions. New and existing landfills designed to hold } \\
\text { at least } 2.5 \text { million Mg of MSW are also required to install gas } \\
\text { collection systems, unless nonmethane organic compounds (NMOCs) } \\
\text { emissions are less than } 50 \mathrm{Mg} \text { per year. About } 280 \text { landfills are } \\
\text { affected. Surface methane must be monitored on a quarterly basis. } \\
\text { Waste disposal cost increases are estimated by EPA at } 20 \text { to } 40 \\
\text { cents per household. By requiring more extensive (and expensive) } \\
\text { LFG control, the rule may encourage some landfills to explore LFG } \\
\text { energy recovery options. However, because the rule increases the } \\
\text { costs of both flaring and energy recovery options, most } \\
\text { owners/operators will likely continue to choose flaring. }\end{array}$ \\
\hline
\end{tabular}

Notes: EPA $=$ U.S. Environmental Protection Agency. FERC = Federal Energy Regulatory Commission.

Source: Science Applications International Corporation, Renewable Industry and Project Descriptions, prepared for the Office of Coal, Nuclear, Electric and Alternate Fuels under contract DE-AC01-92EI21944 (McLean, VA, August 1996).

Because of the expenses related to these regulations, operators were required to show that they had financial mechanisms to cover the costs of closure, postclosure care, and any needed cleanups from releases. Some exemptions were granted to certain small landfills serving communities that dispose of less than 20 tons of MSW per day.

\section{Specific Regulations Pertaining to Landfill Gas and Methane Control}

Both the operating requirements and the closure and postclosure care requirements included provisions for controlling and monitoring LFG. ${ }^{175}$ The box on page 103 shows the regulatory criteria that affect LFG specifically. LFG control and conversion involves the compression of the gas. This compression creates LFG condensate, which is a hazardous waste under RCRA because of its NMOC content. This classification requires disposal either under RCRA or Clean Water Act (CWA) rules. Under RCRA, condensate is treated and safely disposed of at a Subtitle $C$ facility. Under the CWA, it is treated and eliminated through the sewer. ${ }^{176}$

\section{Extension of Some Effective Dates in Federal Landfill Regulations}

In July 1993, the EPA proposed the following modifications to the relevant compliance dates of certain provisions of the October 1991 rule:

- Postponement of the effective date for existing, qualifying smaller landfills from October 9, 1993, to April 9, 1994 ${ }^{177}$

- Elimination of the exemption from groundwater monitoring requirements, and extension of the effective date of the Federal regulations to October 9,1995 , for landfills that previously qualified for the exemption

- Extensions of 6 months for financial assurance and closure requirements for all existing landfills.

\footnotetext{
${ }^{175}$ National Renewable Energy Laboratory, Using Landfill Gas for Energy: Projects that Pay (Golden, CO, May 1994).

${ }^{176} \mathrm{M}$. Doom, J. Pacey, and D. Augenstein, Landfill Gas Energy Utilization Experience: Discussion of Technical and Non-Technical Issues, Solutions, and Trends; and T.D. Williams, "Making Landfill Gas an Asset," Solid Waste \& Power (July/August 1993 ), p. 22.

${ }^{177}$ RCRA defines a small landfill as one serving a community that disposes of less than 20 tons of MSW per day, averaged yearly. For further information, see U.S. Environmental Protection Agency, Criteria for Solid Waste Disposal Facilities: A Guide for Owmers/Operators.
} 


\section{MSW Landfill Criteria Provisions Under Subtitle D of RCRA That Affect LFG and Methane Specifically}

Two of the six MSW landfill gas criteria under the 1991 Subtitle D of RCRA affect LFG and methane specifically. The two criteria, an abbreviated version of the relevant provisions, and the effect on LFG are as follows:

1. Under operation provisions:

- Receipt of regulated hazardous waste-The owner/operator must set up a program to detect and prevent disposal of regulated quantities of hazardous wastes and polychlorinated biphenyl (PCB) wastes. This affects disposal of LFG condensate.

- Cover material-The owner/operator must cover disposed solid waste with at least 6 inches of earthen material at the end of each operating day to control vectors, fires, odors, blowing litter, and scavenging. This inhibits the dispersion of LFG.

- Explosive gases-The owner/operator must set up a program to check for methane gas emissions at least every 3 months. If the limits specified in the regulations are exceeded, the owner/operator must immediately notify the State/Tribal director and take immediate steps to protect human health and the environment. The owner/operator also must develop and implement a remediation plan within 60 days. This encourages the installation and maintenance of LFG control systems.

- Air quality-Owners/operators must comply with the applicable requirements of their State Implementation Plans for meeting Federal (CAA) air quality standards. This encourages the installation and maintenance of LFG control systems, but may discourage energy recovery in favor of flaring.

2. Under closure and postclosure care provisions:

- For 30 years after closure, the owner/operator is responsible for maintaining the integrity of the final cover, monitoring groundwater and methane gas, and continuing leachate management. This encourages the continued operation of LFG control systems after closure.

Source: U.S. Environmental Protection Agency, Criteria for Solid Waste Disposal Facilities: A Guide for Owners/Operators, EPA/530-SW91-089 (Washington, DC, March 1993).

\section{Clean Air Act (CAA) Regulations}

\section{New Source Performance Standards and Emissions Guidelines of 1991}

In 1991, the EPA's Office of Air Quality Planning Standards designated "municipal solid waste landfill emissions" as a pollutant to be regulated under the Clean Air Act (CAA), Section 111(b) (New Source Performance Standards (NSPS) for new landfills) and Section 111(d) (Emissions Guidelines for existing landfills). ${ }^{178}$ The standards limit NMOCs in LFG emissions. NMOCs are of concern because of their interaction with nitrous oxides $\left(\mathrm{NO}_{x}\right)$ to form ozone, a primary cause of smog. Although the guidelines did not directly regulate methane $\left(\mathrm{CH}_{4}\right)$, they did so indirectly by requiring the installation and maintenance of LFG collection and control systems.

\section{Renewable Energy Reserve Credits}

Renewable Energy Reserve credits are available under Title IV of the CAA Acid Rain Program for LFG-to- energy projects. The Renewable Energy Reserve is a special bonus pool of sulfur dioxide $\left(\mathrm{SO}_{2}\right)$ allowances set aside to reward new initiatives in renewable technologies. For every 500 megawatthours of electricity generated through landfill energy recovery, a public utility earns one allowance. The current market value for a sulfur dioxide allowance is approximately $\$ 100$.

\section{New Source Performance Standards and Emissions Guidelines of 1996}

In 1994, the EPA's Office of Air Quality Planing Standards proposed new CAA regulations for new and existing MSW landfills. The final regulation was issued on March 1, 1996. It sets revised performance standards for new landfills and emission guidelines for existing ones. ${ }^{179}$ The regulations require large landfills that emit LFG in excess of 50 megagrams per year to install and maintain technology to control LFG emissions. New and existing landfills designed to hold at least 2.5 million megagrams of MSW are also required to install gas collection systems, unless NMOC emissions are

\footnotetext{
${ }^{178}$ S.A. Thorneloe, "Landfill Gas Utilization-Options, Benefits, and Barriers," paper presented at the Second U.S. Conference on Municipal Solid Waste Management (Arlington, VA, June 3-5, 1992).

${ }^{179}$ U.S. Environmental Protection Agency, Office of Air Quality Planning and Standards, Fact Sheet (Washington, DC, March 1, 1996).
} 
lower than 50 megagrams per year. NMOCs include toxics such as benzene, carbon tetrachloride, and chloroform. ${ }^{180}$

The rule provides owners/operators with a tier system for determining whether controls will be required. If initial calculations determine emissions to be above the limit of 50 megagrams per year, the tier system provides the opportunity to conduct sampling and obtain site-specific values to prove that emissions are below the limit and that controls are not required. The rule also contains an operational standard that requires the monitoring of a landfill's surface methane concentration on a quarterly basis. If the concentration is greater than 500 parts-per-million ( $\mathrm{ppm}$ ) after three consecutive measurements, control system expansion is required.

\section{Other Federal and State Environmental Regulations That Affect the LFG Industry}

The reach of Federal, State, and local environmental regulations is expanding at an increasing rate. Prospective landfill developers must consult different local and State government agencies to obtain the latest version of their solid waste, air quality, and health regulations. A single project or even a project phase may require obtaining multiple permits from different agencies. For instance, 48 pieces of State legislation affecting solid waste were enacted in California in 1991 alone. ${ }^{181}$ As stated earlier, Subtitle D of RCRA sets minimum criteria used by States to establish and enforce their own EPA-approved regulations, which can be more, but not less, strict. A complete list of State regulations affecting landfills would stretch hundreds of pages and is beyond the scope of this report. ${ }^{182}$

\section{Public Utility Regulatory Policies Act of 1978}

A provision under the Public Utility Regulatory Policies Act of 1978 (PURPA) requires utilities to interconnect with small power producers, including LFG energy recovery projects, and purchase the energy at the utilities' avoided cost. In 1995, the Federal Energy Regulatory Commission (FERC) rejected the component of California's Biennial Resource Plan Update that restricted bidding for wholesale power to qualifying facilities (QFs), such as renewable energy resources, compared to other small power producers, such as nonrenewable resources. As a result, States may not assign a preference to bidding for LFG-generated energy under PURPA. FERC also rejected preferential treatment via externality adders that would have the effect of setting rates for QFs above avoided cost.

\section{The Economics of LFG Control and Utilization}

\section{Advantages of LFG Energy Recovery}

The advantages of energy recovery include decreased emissions of methane, NMOCs, and toxics (e.g., benzene, carbon tetrachloride, and chloroform). Although carbon dioxide $\left(\mathrm{CO}_{2}\right)$ emissions increase with the energy recovery option, the net atmospheric balance is a positive one because $\mathrm{CO}_{2}$ emissions are significantly less radiative (i.e., the alleged "greenhouse effect" is less) than methane emissionis.

\section{Economics of Converting LFG Into Energy}

The average size of an LFG energy recovery project is about 3 megawatts, with typically over 95 percent availability. The number of commercial LFG energy recovery projects has grown from 4 in 1981 to about 130 in 1996. ${ }^{183}$ Appendix $\mathrm{H}$ shows selected case studies of LFG commercial energy recovery projects. Even though there has been a large increase in projects, EPA estimates that over 700 landfills across the United States could install economically viable landfill gas energy recovery systems, but have not. In addition, about 30 of the original conversion and direct use projects initiated in the 1970s and 1980s have had to shut down due to more competitive market conditions of the 1990s. ${ }^{184,185,186}$ Therefore, although the advantages of LFG energy recovery are many, there are few successful commercial projects relative to the number of MSW landfills due to prevailing market conditions and the array of other formidable barriers that confront project developers (see box on page 105).

\footnotetext{
${ }^{180}$ National Renewable Energy Laboratory, Using Landfill Gas for Energy: Projects that Pay (Golden, CO, May 1994).

${ }^{181}$ Solid Waste Association of North America, List of Solid Waste Legislation Enacted in 1991 (Silver Springs, MD, 1992).

${ }^{182}$ Telephone communication between Science Applications International Corporation (McLean, VA) and the Bureau of National Affairs, Inc. (Washington, DC) (August 28, 1996).

${ }^{183}$ Personal communication between Science Applications International Corporation (McLean, VA) and S.A. Thomeloe, Global Emissions and Control Division, Air and Energy Engineering Research Laboratory, U.S. Environmental Protection Agency (August 30, 1996).

184 "Landfill Gas Recovery Projects Reviewed by NREL," BioCycle, Vol. 37, No. 2 (February 1996), p. 25.

${ }^{185}$ U.S. Environmental Protection Agency, Landfill Methane Outreach Program, EPA-430-F-95-068A (Washington, DC, April 1995).

${ }^{186}$ Personal communication between Science Applications International Corporation (McLean, VA) and Jean Bogner, Argonne National Laboratory (Chicago, IL) (August 28, 1996).
} 


\section{Barriers to Recovery and Conversion}

- Low oil and gas prices (current and projected future)

- Need for expensive new, sometimes untested, technology (e.g., fuel cells)

- High transportation costs (e.g., dedicated pipelines have to be built for relatively small supplies of gas)

- High debt-service rates for projects that generate electricity or pipeline-quality gas

- Limited or unstable marketplace

- Obtaining third-party project financing at reasonable cost (financing is difficult, time-consuming, and proportionately more costly for small projects than for large ones)

- Difficulties obtaining air permits, especially for projects located in ozone, nitrogen oxide, and carbon monoxide nonattainment areas, because air boards and utilities often have lengthy permit processes and contract negotiations

- Difficulties in negotiating power contracts with local utilities because they are primarily interested in purchasing low-cost power without considering environmental externalities (e.g., offsets from power plants using fossil fuel)

- Unforeseen costs resulting from compliance with new air quality rules and regulations, and declining energy revenues that cannot be adjusted to offset new costs

- Taxation by some States (e.g., California) on LFG extraction and energy conversion facilities

- Difficulties in complying with overlapping Federal and State energy policies and environmental regulations that may affect these projects.

Source: M. Doorn, J. Pacey, and D. Augenstein, Landfill Gas Energy Utilization Experience: Discussion of Technical and NonTechnical Issues, Solutions, and Trends, EPA-600/R-95-035, prepared by E.H. Pechan and Associates, Inc., for the Air and Energy Engineering Research Laboratory, U.S. Environmental Protection Agency (Washington, DC, March 1995).

The most significant barrier is low oil and natural gas prices, which make recovery and conversion, with its high initial capital costs, lack of economies of scale, and high transportation costs, uncompetitive in most cases. Table 30 shows a comparison of current costs for the most popular LFG energy recovery technologies. Table 31 shows a comparison of the conditions deemed necessary by industry to achieve cost-competitive LFG control (i.e., flaring) and utilization projects.

\section{Economics of Direct Uses}

The most economical options for LFG utilization are direct uses such as process heat and boiler fuel, where the end users are in close proximity (no more than 1 or 2 miles) to the landfill, and whose gas supply needs closely match production at the landfill. ${ }^{187}$ In practice, end users are infrequently located near landfills and rarely require continuous fuel in the amounts produced. As of 1992, there were 21 landfills (or less than 20 percent of total energy recovery projects) with direct use of LFG as heating fuel. ${ }^{188}$

Boiler fuel is the most typical direct use and a particularly attractive option since conventional equipment can be used with minimal modifications. Boilers are generally less sensitive to LFG trace constituents and therefore require less cleanup than other alternatives. Enduse options include industrial applications such as kilns, lumber drying, oil refining, hotel heating, and cement manufacturing. These tend to be economical applications because of the continuous need and availability of the fuel.

\section{Economics of Electricity Generation}

Generally, there are three applications for LFG electricity generation: internal combustion engines, gas turbines, and fuel cells. As of 1992, there were about 61 projects that generated electricity using internal combustion (IC) engines and 24 using turbines, accounting for a total output of 344 megawatthours. ${ }^{189}$ Today, most of the operating landfill energy recovery projects sell electricity under contract to a utility. IC engines are most economical where the supply of LFG is enough to produce 1 to 3 megawatthours. Turbines are most economical at sites with output of over 3 megawatthours. Advantages of IC engines include comparatively low capital costs (between $\$ 950$ and $\$ 1,250$ per kilowatt), efficiency, a high degree of standardization, and ease of transportation from one landfill site to another. ${ }^{190}$ One of the disadvantages with IC engines is emissions. There are two types of IC engines, each having distinct

\footnotetext{
${ }^{187}$ M. Doorn, J. Pacey, and D. Augenstein, Landfill Gas Energy Utilization Experience: Discussion of Technical and Non-Technical Issues, Solutions, and Trends.

${ }^{188}$ S.A. Thorneloe, "Landfill Gas Utilization-Options, Benefits, and Barriers."

${ }^{189}$ S.A. Thorneloe, "Landfill Gas Utilization-Options, Benefits, and Barriers."

${ }^{190} \mathrm{M}$. Doorn, J. Pacey, and D. Augenstein, Landfill Gas Energy Utilization Experience: Discussion of Technical and Non-Technical Issues, Solutions, and Trends.
} 
Table 30. Comparison of Costs for Typical LFG Energy Recovery Technologies (1992 Dollars, Unless Otherwise Noted)

\begin{tabular}{|c|c|c|}
\hline Technology/Use & $\begin{array}{c}\text { Capital Costs } \\
\text { (Dollars per Kilowatt) }\end{array}$ & $\begin{array}{l}\text { Operating and Maintenance Costs } \\
\text { (Dollars per Kilowatthour) }\end{array}$ \\
\hline Internal Combustion Engine/Electricity Generation..... & 900 to 1,200 & 0.013 to 0.020 \\
\hline Gas Turbine/Electricity Generation & 1,000 to 1,500 & 0.01 to 0.015 \\
\hline Steam Turbine/Electricity Generation & ${ }^{a} \mathbf{9 0 0}$ & ${ }^{\mathrm{a}} 0.001$ \\
\hline Boiler/Direct Heat & 1,000 to 1,500 & 0.005 to 0.018 \\
\hline Organic Rankine/Heat Recovery & 1,000 to 1,500 & 0.005 \\
\hline Fuel Cell/Electricity Generation ... & $b_{3,000+}$ & NA \\
\hline
\end{tabular}

$a_{1993}$ dollars.

$b_{1995}$ dollars, using 1995 technology.

NA = not available.

Sources: T.D. Williams, "Making Landfill Gas an Asset," Solid Waste and Power (July/August 1992), p. 22; and C.E. Anderson, "Selecting Electrical Generating Equipment for Use with Landfill Gas," Proceedings of the SWANA 16th Annual Landfill Gas Symposium (Louisville, KY, March 1993).

emissions characteristics. Stoichiometric combustion engines generate high nitrous oxides $\left(\mathrm{NO}_{\mathrm{x}}\right)$ emissions. Lean-burn engines generate lower $\mathrm{NO}_{x}$ and $\mathrm{CO}$ emissions, so they are better suited for applications where these emissions are a concern.

There are several economic disadvantages in using gasfed turbines. According to Waste Management of North America, gas fed turbines typically have parasitic energy losses of 17 percent of gross output. ${ }^{191}$ This compares to 7 percent for IC engines. Turndown ${ }^{192}$ performance is poor compared with IC engines, and difficulties may occur when they are operated at less than a full load. Other problems can be combustion chamber melting, corrosion, and accumulation of deposits on turbine blades. Thus, IC engines are currently the most favorable option for LFG energy conversion projects and have been applied in greater numbers than any other option.

In the future, fuel cells may become attractive because of their higher energy efficiency, negligible emissions impact, and suitability for all landfill sizes, although some studies suggest that fuel cells would be more competitive in small (less than 1 megawatt) to medium (less than 3 megawatts) projects. ${ }^{193}$ In addition, fuel cells have low labor and maintenance costs. At present, however, economic and technical disadvantages make fuel cells clearly uncompetitive with more conventional applications. These include the high capital cost of designing an LFG cleanup process that can remove the trace constituents from the LFG (fuel cells need a higher grade of LFG purification than other options), and the high cost of the fuel cell itself (about $\$ 3,000$ per kilowatt using state-of-the-art technology). Because of continued advances in fuel cell technology and the possibility of more stringent future emissions requirements that may make other technologies more costly, some studies estimate that fuel cells will become competitive around the turn of this century. (A manufacturer estimates capital costs as low as $\$ 1,500$ per kilowatt by 1998) ${ }^{194}$ According to a study by the Electric Power Research Institute (EPRI), if individual fuel cell power plants were used at landfills, 6,000 megawatthours of electricity could be generated from LFG. ${ }^{195}$ Another study prepared for the EPA suggests that the approximate total power output that could be generated from about 7,500 landfills using fuel cell energy recovery could be 4,370 megawatthours. ${ }^{196}$

\footnotetext{
${ }^{191}$ Unless otherwise noted, the technical information on gas turbines and IC engines was obtained from M. Doorn, J. Pacey, and D. Augenstein, Landfill Gas Energy Utilization Experience: Discussion of Technical and Non-Technical Issues, Solutions, and Trends.

${ }^{192}$ Turndown refers to gas line pressure. The efficient performance of gas-fed turbines is more sensitive to gas line pressure than is the performance of internal combustion engines.

${ }^{193}$ G.J. Sandelli, Demonstration of Fuel Cells To Recover Energy from Landfill Gas. Phase I Final Report: Conceptual Study, EPA-600-R-92-007, prepared for the U.S. Environmental Protection Agency by International Fuel Cells Corporation (Washington, DC, January 1992).

${ }^{194}$ According to ONSI Corporation, a subsidiary of International Fuel Cell Corporation (the fuel cell production arm of United Technologies Corporation). See M. Doorn, J. Pacey, and D. Augenstein, Landfill Gas Energy Utilization Experience: Discussion of Technical and Non-Technical Issues, Solutions, and Trends.

${ }^{195}$ W.D. Siuru, "Researchers Test Fuel Cells To Recover LFG," World Wastes, Vol. 38, No. 4 (April 1995), p. 8.

${ }^{196}$ G.J. Sandelli, Demonstration of Fuel Cells To Recover Energy from Landfill Gas. Phase I Final Report: Conceptual Study.
} 
Table 31. Conditions Necessary for Cost-Competitiveness in LFG Utilization Projects

\begin{tabular}{|c|c|c|c|c|c|c|c|}
\hline \multirow[b]{2}{*}{$\begin{array}{c}\text { Project Developer/ } \\
\text { Source }\end{array}$} & \multirow[b]{2}{*}{ Technology } & \multirow[b]{2}{*}{$\begin{array}{c}\text { Administrative } \\
\text { and } \\
\text { Development } \\
\text { Costs }\end{array}$} & \multicolumn{5}{|c|}{ Minimum Necessary Conditions } \\
\hline & & & $\begin{array}{c}\text { Minimum } \\
\text { Output }\end{array}$ & \begin{tabular}{|} 
Minimum Price \\
Paid for \\
Project \\
Electricity
\end{tabular} & $\begin{array}{c}\text { Royaities to } \\
\text { Landfill and } \\
\text { Emission } \\
\text { Credits }\end{array}$ & $\begin{array}{l}\text { Pipeline Length } \\
\text { (if applicable) }\end{array}$ & $\begin{array}{c}\text { Tax } \\
\text { Incentives }\end{array}$ \\
\hline $\begin{array}{l}\text { Laidlaw Technology, } \\
\text { Inc. }^{\mathrm{a}} \text { (1992) }\end{array}$ & Gas turbine & $\begin{array}{l}\text { Can vary greatly, } \\
\text { from } \$ 30,000 \text { to } \\
\$ 1 \text { million per } \mathrm{kW} \\
\text { for a } 1-\mathrm{MWe} \\
\text { project }\end{array}$ & $>1 \mathrm{MWe}$ & $\begin{array}{l}\text { At least } \$ 0.06 \text { to } \\
\$ 0.07 \text { per } k W h\end{array}$ & $\begin{array}{l}\text { Less than } \\
12.5 \text { percent }\end{array}$ & Less than 2 miles & $\begin{array}{l}\text { Tax credits } \\
\text { necessary } \\
\text { when energy } \\
\text { prices are } \\
\text { low }\end{array}$ \\
\hline $\begin{array}{l}\text { International Fuel } \\
\text { Cells Corporation } \\
\text { (Conceptual Study) }\end{array}$ & $\begin{array}{l}\text { Fuel cell: mature } \\
\text { technology and } \\
\text { economies of } \\
\text { scale }\end{array}$ & $\begin{array}{l}\$ 1,500 \text { per } \mathrm{kW} \\
\text { (including credits } \\
\text { and assuming } 50 \\
\text { percent heat } \\
\text { recovery sold at } \\
\$ 2.92 \text { per million } \\
\text { Btu) }\end{array}$ & $4 \times 200 \mathrm{~kW}$ & $\$ 0.04$ per kWh & $\begin{array}{l}\text { Emission } \\
\text { offset: } \\
\$ 1,000 \mathrm{per} \\
\text { ton of } \mathrm{NO}_{\mathrm{x}} \\
\text { and } \mathrm{SO}_{\mathrm{x}}\end{array}$ & NA & Yes \\
\hline $\begin{array}{l}\text { International Fuel } \\
\text { Cells Corporation } \\
\text { (Conceptual Study) }\end{array}$ & $\begin{array}{l}\text { Fuel cell: today's } \\
\text { technology and } \\
\text { no economies of } \\
\text { scale }\end{array}$ & $\begin{array}{l}\$ 3,000 \text { per } \mathrm{kW} \\
\text { (including credits } \\
\text { and assuming } 50 \\
\text { percent heat } \\
\text { recovery sold at } \\
\$ 2.92 \text { per million } \\
\text { Btu }\end{array}$ & $4 \times 200 \mathrm{~kW}$ & $\$ 0.072$ per kWh & $\begin{array}{l}\text { Emission } \\
\text { offset: } \\
\$ 1,000 \text { per } \\
\text { ton of } \mathrm{NO}_{\mathrm{x}} \\
\text { and } \mathrm{SO}_{\mathrm{X}}\end{array}$ & NA & Yes \\
\hline$N A^{b, c}$ & Flare system & $\begin{array}{l}\text { About } \$ 375 \text { per } \\
\text { million standard } \\
\text { cubic feet of LFG } \\
\text { processed per } \\
\text { year }\end{array}$ & NA & $\$ 0.07$ per kWh & None & NA & No \\
\hline
\end{tabular}

aG.R. Jansen, "The Economics of LFG Projects in the United States," presented at the Symposium on LFG/Applications and Opportunities (Melbourne, Australia, February 27, 1992).

${ }^{b}$ G.J. Sandelli, Demonstration of Fuel Cells To Recover Energy from Landfill Gas. Phase I Final Report: Conceptual Study, EPA-600-R-92-007, prepared by International Fuel Cells Corporation for the U.S. Environmental Protection Agency (Washington, DC, January 1992).

${ }^{C}$ G.J. Sandelli (1992) and Science Applications International Corporation, Renewable Energy Annual 1996. Subtask II: Issues, prepared for the Energy Information Administration under Contract No. DE-AC01-92-El21944 (McLean, VA, September 11, 1996).

$\mathrm{Btu}=$ British thermal units. $\mathrm{kWh}=$ kilowatthours. $M W e=$ megawatt-electric. $\mathrm{NA}=$ not applicable.

\section{Economics of Using LFG as a Feedstock in Chemical Manufacturing Processes}

This option involves the use of expensive cleanup, purification, and processing equipment to bring the LFG to the quality standards of alternative feedstocks, such as natural gas. Using LFG as a chemical manufacturing feedstock remains largely uneconomical as long as the price of conventional feedstocks (e.g., natural gas) remains low. Other disadvantages are high transportation costs and a need for proximity to the end user. Landfill sites have found that gas pipelines cannot exceed 1 or 2 miles to be cost-effective. ${ }^{197}$ Potential uses for the feedstock include production of methanol and diesel fuels.

\section{Economics of Gas Purification to Pipeline-Quality Gas}

This option involves the conversion of LFG, a medium heating value gas, into high heating value gas for local gas distribution networks or, in compressed form, for vehicular fuel. In 1992, there were seven sites that upgraded LFG to pipeline-quality gas. ${ }^{198}$ This option also remains uneconomical as long as the prices of natural gas and oil remain relatively low. Disadvantages include the need for a more thorough and expensive purification process than in some other options (but the same as in feedstock for chemical manufacturing processes and fuel cell applications), high transportation costs, and need for proximity to the end-user.

${ }^{197}$ S.A. Thorneloe, "Landfill Gas Utilization-Options, Benefits, and Barriers."

${ }^{198}$ M. Doorn, J. Pacey, and D. Augenstein, Landfill Gas Energy Utilization Experience: Discussion of Technical and Non-Technical Issues, Solutions, and Trends. 


\section{Nonregulatory Government Promotion of LFG Use}

The U.S. Government has an impact on the LFG industry and on the development of energy recovery projects through promotional programs and incentives. The aim of these incentives and programs is to encourage LFG utilization projects, particularly when the projects are not cost-effective due to market conditions or the use of new technology. The EPA has the most important programs regarding MSW landfills. This section provides a brief discussion of EPA's promotional programs and of other U.S. Government incentives and programs.

\section{EPA Activities}

\section{Landfill Methane Outreach Program}

The Landfill Methane Outreach Program, part of the Climate Change Action Plan, is an important Government program dealing with LFG and energy recovery. Through this program, EPA is working with MSW landfill owners/operators, States, Tribes, utilities, and other Federal agencies to promote the use of LFG as an energy resource. ${ }^{199}$ The program has two main tasks: (1) identifying landfills with the potential to produce energy cost-effectively; and (2) overcoming the barriers to LFG energy recovery at the Federal, State, and local levels. A summary of the outreach services offered by the program appears in the box opposite. The critical barriers identified by the program are shown in Table 32.

Some of the program's outreach objectives are met through EPA's Landfill Methane Outreach "Ally" voluntary programs with State governments, utilities, and owner/operators. EPA launched these programs in five States during fall 1994; the nationwide launch took place in $1996 .{ }^{200}$

In the State Allies program, the EPA and a State government office sign a voluntary memorandum of understanding which sets forth the responsibilities and agreements between the parties to make the State government party a Landfill Methane Outreach State Ally.

In the Utility Allies program, utilities are encouraged to purchase electricity generated from LFG. To become a Utility Ally, a utility agrees to take advantage of the best opportunities in its service territory (or beyond) for obtaining power from LFG. In turn, EPA recognizes and publicizes the utility's efforts. EPA can also assist

\section{Outreach Services of EPA's Landfill Methane Outreach Program}

- A telephone assistance service for questions about collection, control, and utilization of LFG

- Provision of sample requests for proposals (RFPs) to landfill owners/operators, utilities, State regulators, and others who can use the samples in starting up LFG collection and utilization projects

- Release of case study reports on landfill successes to raise awareness of emissions reduction potential and the economics of control and conversion

- Organization of a series of State and regional workshops on landfill energy recovery opportunities

- Initiation of site visits to develop feasibility analyses of project opportunities

- Research in coordination with the U.S. Department of Energy targeting the technical barriers to energy recovery.

Sources: National Renewable Energy Laboratory, Using Landfill Gas for Energy: Projects that Pay (Golden, CO, May 1994); and U.S. Environmental Protection Agency, Landfill Methane Outreach Program, EPA-430-F-95-068A (Washington, DC, April 1995).

during evaluation and development of projects and in removing or alleviating the regulatory, information, and other barriers currently limiting development (Table 32). As in the State Ally program, utilities become allies by signing a memorandum of understanding with EPA. The National Association of Regulatory Utility Commissioners (NARUC) recognized the importance of the Utility Allies program by adopting a resolution in March 1994 "encourag[ing] and support[ing] its member commissions' and utilities' active participation in the Outreach program. ${ }^{\prime 201}$

The Industry Allies program encourages use of the most appropriate energy recovery technology on a siteby-site basis. Industry Allies include several types of organizations: LFG-to-energy developers, engineering consulting firms, equipment suppliers, project facilitators, project financiers, and LFG end users. Industry Ally project developers currently account for over 60 of about 100 U.S. LFG-to-energy projects.

\footnotetext{
${ }^{199}$ National Renewable Energy Laboratory, Using Landfill Gas for Energy: Projects that Pay (Golden, CO, May 1994).

${ }^{200}$ U.S. Environmental Protection Agency, Landfill Methane Outreach Program, EPA-430-F-95-068A (Washington, DC, April 1995).

${ }^{201}$ Solid Waste Association of North America, web site www.swana.org (August 20, 1996).
} 
Table 32. Critical Barriers Identified by the Landfill Methane Outreach Program and Their Solutions

\begin{tabular}{l|l}
\hline \multicolumn{1}{c|}{ Critical Barriers } & \multicolumn{1}{c}{ Program Solutions } \\
\hline Lack of information and perception of high risk & $\begin{array}{l}\text { Provide information to increase awareness of project opportunities and } \\
\text { enhance understanding of environmental, energy, and economic benefits } \\
\text { Costly and difficult permitting and other regulatory } \\
\text { hurdles }\end{array}$ \\
$\begin{array}{l}\text { Poor market conditions: rate of return not high } \\
\text { enough }\end{array}$ & $\begin{array}{l}\text { Work with utilities and other energy purchasers to increase recognition } \\
\text { streamline the regulations affecting development of projects } \\
\text { of the environmental value of energy recovery and its energy resource } \\
\text { benefits }\end{array}$ \\
$\begin{array}{l}\text { Misperception of profitability based on avoided cost } \\
\text { rates that are no longer available }\end{array}$ & $\begin{array}{l}\text { Raise awareness of the benefits of energy recovery as a cost-effective } \\
\text { approach to achieving a range of environmental and safety goals }\end{array}$
\end{tabular}

Source: U.S. Environmental Protection Agency, Landfill Methane Outreach Program, EPA-430-F-95-068A (Washington, DC, April 1995).

\section{Other EPA Activities}

In addition to the outreach program, EPA offers technical assistance through its Control Technology Center. Other EPA activities include research by the Air and Energy Engineering Research Laboratory (AEERL), which provides information on energy conversion options for LFG utilization, specifically to owners/ operators affected by CAA regulations. ${ }^{202}$

\section{Other Federal and State Government Incentives ${ }^{203}$}

\section{Tax Credits and Exemptions}

The most important tax credits are the Federal Production Tax Credits (PTCs), established in 1979 under Section 29 of the Tax Code. Credits are a direct offset to taxes and can only be used to offset a profit. The tax credits will apply until 2008 and are allowable for LFG extraction systems installed prior to the end of 1992. The credit was $\$ 0.94$ per million Btu in 1992.

On July 9, 1996, the Senate approved a package that includes an extension for the Section 29 tax credits. ${ }^{204}$ If signed into law, the package will extend the Section 29 deadline for a written binding contract to 6 months after the provision's enactment and extend the "placed in service" date to January 1, 1999. No extension was granted for the duration of the availability of the tax credit.
There are also State tax exemptions, such as those on LFG extraction (i.e., collection) and energy conversion facilities. Some State governments, such as California, tax these same systems.

\section{State Price Incentives}

The most important State incentives are favorable utility contracts for electricity projects, created to counter poor market conditions. A good example is California's Standard Offer No. 4, a price-favored contract that utilities were required to offer in the 1980s. Beginning in 1984, this incentive encouraged several LFG-toenergy projects, the last of which started in 1990; however, FERC rulings on above-avoided cost purchases have eliminated this and similar programs. ${ }^{205}$ Other States that adopted incentives programs are New Jersey, New York, and Pennsylvania (now canceled), as well as Illinois, Michigan, and Wisconsin (still in place).

\section{U.S. Department of Energy}

There are three U.S. Department of Energy (DOE) programs with the objective of encouraging the development of LFG energy recovery projects:

- Research, Development, and Demonstration (RD\&D) Program-Part of the Climate Change Action Plan, which targets the technical barriers to landfill methane energy recovery

\footnotetext{
${ }^{202}$ M. Doorn, J. Pacey, and D. Augenstein, Landfill Gas Energy Utilization Experience: Discussion of Technical and Non-Technical Issues, Solutions, and Trends.

${ }^{203}$ Information obtained from M. Doorn, J. Pacey, and D. Augenstein, Landfill Gas Energy Utilization Experience: Discussion of Technical and Non-Technical Issues, Solutions, and Trends.

${ }^{204}$ Solid Waste Association of North America, web site www.swana.org (August 20, 1996).

${ }^{205}$ Some States are planning to circumvent FERC by requiring utilities that sell at retail to buy a certain percentage of their energy from renewable supplies. As of summer 1996, no State had actually implemented such a program.
} 
- Climate Challenge-A DOE initiative in which utilities agree to achieve greenhouse gas reductions in a way that makes sense for them

- Voluntary Reporting-A DOE program in which utilities are eligible to report methane reductions from landfill energy recovery projects.

\section{Economic Impacts of Regulations, Programs, and Incentives}

\section{Municipal Solid Waste Landfill Regulations Under RCRA and CAA}

Because of the self-implementing nature of the regulations under Subtitle D of RCRA, the stringency of State regulations affecting MSW landfills varies widely. In some cases, State regulations are much more demanding than Federal regulations (e.g., New York, New Jersey), while in other cases, States simply enforce the Federal regulations. Overall, however, increased compliance costs have forced many landfills to shut down.

The United States had 7,683 landfills in 1986 but just 5,345 in 1992. Before the 1992 list was updated, the final rule for solid waste disposal facility criteria (40 CFR Parts 257 and 258, October 9, 1991) was published. The rule allowed a facility to comply only with final cover requirements if it stopped receiving waste within 24 months. The effect of this rule was a further decline in active landfills to 3,581 in 1995.
Table 33 shows typical landfill costs, and LFG control costs in particular, before and after the 1991 version of Subtitle D of RCRA. As shown in Table 33, there was a considerable increase in landfill management costs between 1975 and 1988, followed by a smaller increase from 1988 to 1990 . These increases are mostly due to the higher costs of compliance with successive versions of Subtitle D of RCRA. The weight of each item has also changed over time, as provisions have required increasingly expensive construction and postclosure care. The table also shows that the RCRA provisions that address LFG operations have contributed to increased costs in real terms, but not as a percentage share of the total cost of the project. On the other hand, the RCRA provisions that address LFG under the closure and postclosure care criteria may have contributed to increased costs both in real terms and as a percentage share of the total cost of the project.

In terms of RCRA's impact on the economics of LFG energy recovery projects, there are two main issues. First, hazardous waste disposal regulations impose a cost for disposal of LFG condensate of between $\$ 0.70$ and $\$ 1.50$ per gallon (compared with less than $\$ 0.01$ per gallon for sewering, in the absence of regulation). In contrast, condensate disposal costs are about 80 percent lower when the LFG is flared (i.e., 1,000 gallons per day for energy recovery vs. 200 for flaring). Thus, while these regulations reduce emissions ${ }^{206}$ (particularly for methane) they discourage the utilization of LFG and encourage flaring. Second, RCRA's requirement for

Table 33. Comparison of MSW Landfill Costs Before and After the 1991 RCRA Regulations

\begin{tabular}{|c|c|c|c|c|c|c|}
\hline \multirow[b]{3}{*}{ Cost Item } & \multicolumn{6}{|c|}{$\begin{array}{l}\text { Typical Costs per Ton and Percentage Share of Total, } \\
\text { by Year and RCRA Compliance Status }\end{array}$} \\
\hline & \multicolumn{2}{|c|}{$\begin{array}{l}1975 \text { Landfill Not in } \\
\text { Compliance with } 1976 \text { RCRA }\end{array}$} & \multicolumn{2}{|c|}{$\begin{array}{l}1988 \text { Landfill in Compliance } \\
\text { with } 1976 \text { RCRA }\end{array}$} & \multicolumn{2}{|c|}{$\begin{array}{l}1990 \text { Landfill in Compliance } \\
\text { with } 1991 \text { RCRA }\end{array}$} \\
\hline & $\begin{array}{l}1988 \text { Dollars } \\
\text { per Ton }\end{array}$ & $\begin{array}{l}\text { Percent of } \\
\text { Total }\end{array}$ & $\begin{array}{l}1988 \text { Dollars } \\
\text { per Ton }\end{array}$ & $\begin{array}{l}\text { Percent of } \\
\text { Total }\end{array}$ & $\begin{array}{l}1988 \text { Dollars } \\
\text { per Ton }\end{array}$ & $\begin{array}{l}\text { Percent of } \\
\text { Total }\end{array}$ \\
\hline Pre-development ... & 0.25 & 5.9 & $0.42-1.30$ & $3-6$ & 1.50 & 7.3 \\
\hline Construction & 0.52 & 12.3 & $2.60-4.90$ & $15-25$ & 5.00 & 24.4 \\
\hline Operations. & 3.20 & 75.7 & $4.50-8.50$ & $30-40$ & 8.00 & 39.0 \\
\hline Closure $\ldots \ldots \ldots$ & 0.26 & 6.1 & $0.50-1.00$ & $3-5$ & 1.00 & 4.8 \\
\hline Post-closure care .. & 0.00 & 0.0 & $2.00-4.00$ & $10-20$ & 3.00 & 14.7 \\
\hline Unanticipated .. & 0.00 & 0.0 & $1.00-2.50$ & $5-15$ & 2.00 & 9.8 \\
\hline Total . . . . . . . . & 4.23 & 100.0 & $11.02-22.20$ & 100.0 & 20.50 & 100.0 \\
\hline
\end{tabular}

Source: R.T. Glebs, “Subtitle D: How Will it Affect Landfills?” Waste Alternatives (Summer 1988).

\footnotetext{
${ }^{206}$ Assuming that the combustion efficiencies of flaring and energy recovery are similar, the $\mathrm{CO}_{2}$ emissions are comparable. Therefore, if the LFG were redirected through an energy conversion combustor/generator rather than flared, no new $\mathrm{CO}_{2}$ emissions would be created.
} 
CAA compliance raised costs by requiring expensive emission prevention systems or applying penalties.

The cost impact of the 1996 New Source Performance Standards and Emissions Guidelines under the CAA will be minimal. Only about 280 landfills are affected by the regulations. Of the 900 new landfills projected to open during the next 5 years, approximately 45 will be subject to the regulation. By requiring more extensive (and expensive) LFG control, the rule may encourage some landfills to explore LFG energy recovery options. However, because the rule increases the costs of both flaring and energy recovery options, most owners/ operators will likely continue to choose flaring.

\section{State and Local Environmental Regulations}

The reach of State and local environmental regulations is expanding at an increasing rate. According to industry sources, the costs for LFG energy recovery projects of complying with all pertinent regulations are escalating faster than the inflation rate and original financial assumptions. ${ }^{207}$ An example is a penalty for the $\mathrm{CO}_{2}$ content in emissions from engines in California, which applies specially to LFG energy conversion projects that use IC engines. The penalty can add as much as 1.5 cents per kilowatthour to operating expenses.

\section{Federal Energy Regulatory Commission}

The FERC's rejection of the component of California's Biennial Resource Plan Update that restricted bidding for wholesale power to QFs means that States may not assign a preference to bidding for LFG-generated energy under PURPA. States also may not assign externality benefits to particular technologies.

\section{EPA, DOE, and Other Federal Incentives}

Although the EPA's Landfill Methane Outreach Program has identified the most important barriers to energy recovery projects, its solutions so far have been mostly cosmetic. While its role of providing reliable information to the marketplace is necessary, the solution to the main identified barrier is well beyond its capabilities; no amount of recognition of the environmental value of energy recovery is likely to have a significant impact on LFG energy recovery project development until rates of return are comparable to those of fossil fuel alternatives.

DOE and EPA research programs have not, so far, resulted in significant commercial project developments. Critics of technology demonstration programs argue that they amount to ineffectual government industrial policy that misallocates public resources. To others, however, these projects are essential to maintain private sector interest in emerging technologies, which may result in commercially viable projects by the turn of the century.

For the purpose of LFG energy recovery project development, the most significant positive impact is that of the Federal production tax credits for LFG extraction systems of \$0.94 per million Btu in 1992.

\section{Impact of State Incentives}

State incentives in the form of favorable utility contracts for electricity projects have contributed to the development of LFG energy recovery projects more than any other government incentive or program. The historical record indicates that these incentives are essential for some projects, which would otherwise be forced to shut down if the pricing structure reverts to the avoided-cost basis. It is no coincidence that the seven States that have offered or are currently offering incentives are also the top seven in terms of number of projects and account for about three-quarters of all projects in the United States. ${ }^{208}$

${ }^{207}$ F.P. Wong, Alternative Energy and Regulatory Policy: Till Death Do We Part (Commerce, CA: Pacific Energy, March 1992).

${ }^{208} \mathrm{M}$. Doorn, J. Pacey, and D. Augenstein, Landfill Gas Energy Utilization Experience: Discussion of Technical and Non-Technical Issues, Solutions, and Trends. 


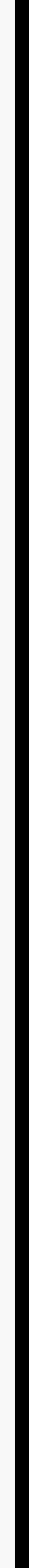




\section{Management of Known Geothermal Resource Areas}

An ongoing issue in the geothermal power industry is the prudent management of finite geothermal resources. Known geothermal resource areas (KGRAs) in the United States with resource conditions sufficient to generate electricity are rare, occurring domestically only in the Western United States and Hawaii, with an estimated electricity generating capacity of 27,400 megawatts, which is believed to be sustainable for 40 years. Of the currently identified resource base in the United States, around 3,000 megawatts of capacity, or about 10 percent of the estimated total, was installed as of 1995. The successful planned management of one U.S. KGRA, Coso Hot Springs, is described here.

The major industry concern about KGRAs is, and for the past decade has been, the declining production at The Geysers, located along the San Andreas Fault in Sonoma County, California. The Geysers KGRA produces more electricity than any other geothermal field in the world. This chapter presents historical information on the geology, sale, corporate structure, and financial aspects of The Geysers project, specifically addressing the production decline, plans for a pipeline that will carry wastewater to one corner of the field for injection as a strategy for mitigating the decline, and lessons learned from the production decline.

\section{Coso Hot Springs \\ Coso KGRA Development}

Coso Hot Springs (Table 34) is in the middle of the Mohave desert of California, closer to Death Valley than to any metropolitan area. It lies within the boundaries of the China Lake Naval Air Weapons Station (NAWS). The U.S. Navy operates the NAWS as a site for testing Navy weapons.

The Navy's purposes in developing the Coso Hot Springs KGRA were threefold: ${ }^{209}$

- To manage the electricity generation component of NAWS expansion

- To provide an alternative energy source, allowing the Navy shore facility to reduce overall Navy dependence on fossil fuels, especially imported fuels

- To provide a $\$ 40$ million cost saving on utility bills over the first 10 years of operation.

To meet these objectives, development and operation of the field were contracted out, with the electricity being sold to the utility servicing the area, Southern California Edison.

Table 34. Coso Geothermal Power Plant Statistics

\begin{tabular}{|c|c|c|}
\hline & Navy One And Two & $\begin{array}{c}\text { BLM East, Units } 7 \text { and } 8, \\
\text { BLM West, Unit } 9^{\mathrm{a}}\end{array}$ \\
\hline Rated Output $\ldots \ldots \ldots \ldots \ldots$ & 160 megawatts & 90 megawatts \\
\hline Rated Steam Pressure ........ & 80 pounds per square inch & 一 \\
\hline Rated Steam Temperature ..... & $311.9^{\circ}$ Fahrenheit & - \\
\hline Number of Turbines $\ldots . . .$. & 6 & 3 \\
\hline Purchasing Utility $\ldots \ldots \ldots \ldots$. & Southern California Edison & - \\
\hline Net Production $\ldots \ldots \ldots \ldots \ldots$ & 2,318,400 megawatthours delivered in 1995 & \\
\hline
\end{tabular}

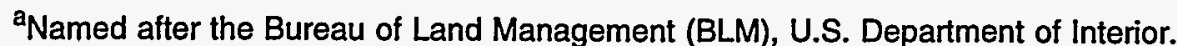

Source: Geothermal Program Office, Naval Air Weapons Station, China Lake, CA.

${ }^{209}$ Information obtained from the Geothermal Program Office, Naval Air Weapons Station, China Lake, CA. 


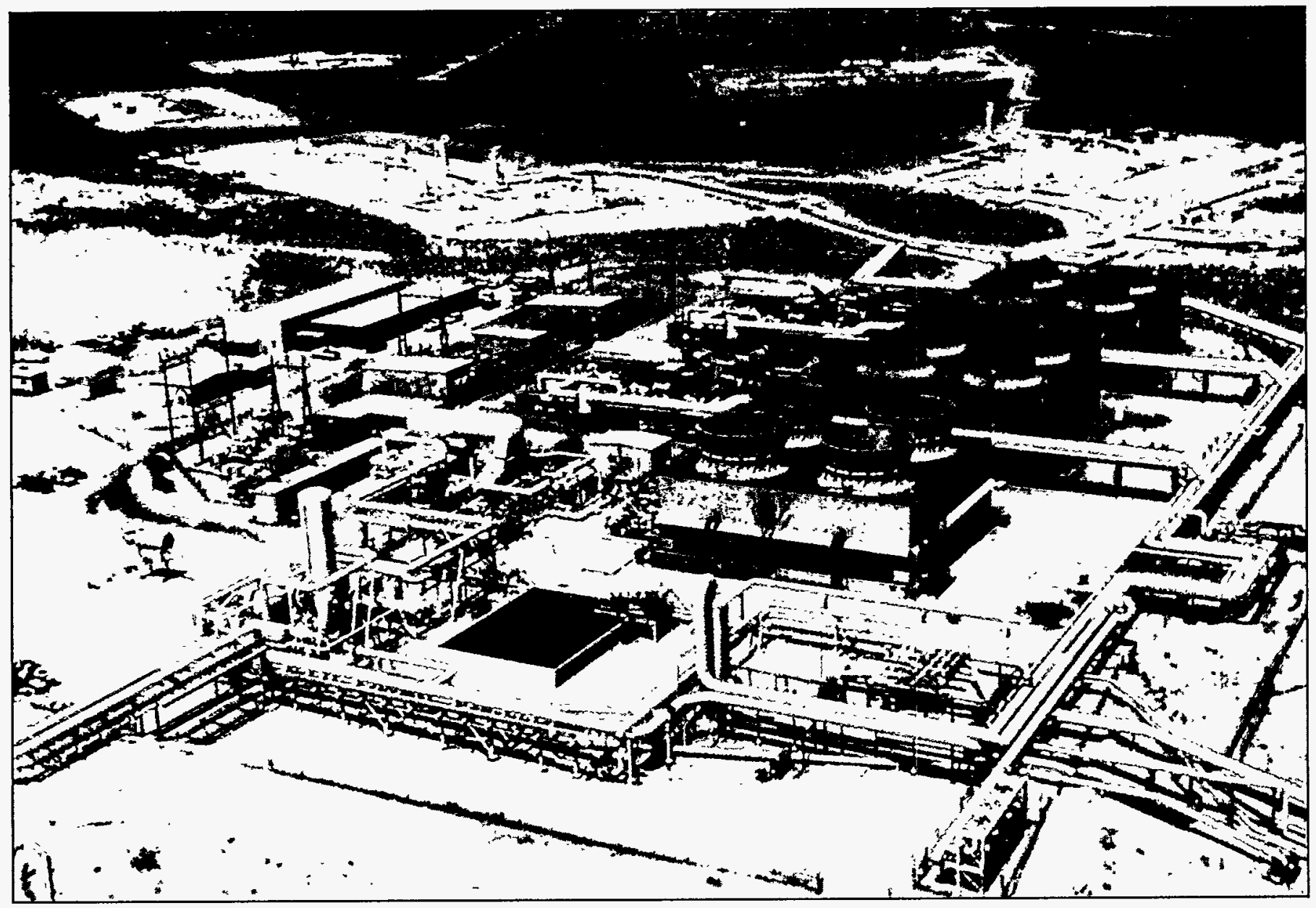

The three-unit Navy I Coso Geothermal Plant in Coso Hot Springs, CA.

The Navy contracted with CalEnergy Company, Inc. (CECI) to support the development of the field. At this point, CECI, the Nation's largest geothermal corporation, owns or operates:

- About half of the Coso Hot Springs project

- Seven operating geothermal facilities in the Imperial Valley, including the Nation's most recent geothermal power plant, Salton Sea IV

- All of the operations at Desert Peak in Nevada

- The well field at Roosevelt Hot Springs in Nevada.

\section{Advantages to the Navy}

From 1987 through 1993, the Naval Weapons Center (now NAWS, China Lake) received direct reductions in its electricity bill totaling $\$ 24.2$ million as a result of electricity production from Coso Hot Springs. The saving for calendar year 1993 alone was $\$ 4.2$ million, which equates to a one-third reduction in electrical energy cost.
In cooperation with private industry, NAWS China Lake has promoted the development of its geothermal resource in a way that ensures continued Navy control and supports Navy goals. The production from Coso was equivalent to 16 percent of 1993 electricity consumption by Navy shore facilities. This is a significant step toward meeting the directives of the Chief of Naval Operations regarding the conversion of Navy shore facilities to operating on alternative energy sources.

Other benefits to the Navy are derived from the sale of excess electricity by the contractor, CECI, to the local utility company, Southern California Edison. The project allows the Navy to manage the resource, including administering the contract, funding an exploration program, and supporting energy cost avoidance projects. All of this is done without expenditure by the Navy for the plant construction or plant operation.

Benefits are also realized in the local economy through taxes, jobs, and economic stimulation. Taxes paid to 
Inyo County by the project have amounted to more than 20 percent of the county's income in recent years.

Total generating capacity at the Coso geothermal field amounts to more than 250 megawatts. If 1 megawatthour of electricity will meet the hourly needs of approximately 1,000 households, and assuming an average of 2.5 people per household, the output from Coso can provide enough power to serve approximately 625,000 people. The week of peak production in 1987 averaged 266.4 megawatts per hour, generating roughly 6,400 megawatthours (1.9 billion Btu) per day, sufficient for 640,000 residential consumers per day, assuming that each person's electricity consumption was equal to the 1995 national average. ${ }^{210}$

In addition to a reliable source of power, Coso provides a significant benefit to air quality in the environs. Coso's geothermal power plants have sulfur emissions rates that average only a few percent of those from fossil fuel alternatives: less than 1 pound of carbon dioxide per megawatthour of electricity generated, as compared with 14.47 million metric tons of carbon per quadrillion Btu (328 pounds of carbon dioxide per megawatthour) for a plant fueled by natural gas and 25.71 million metric tons ( 583 pounds per megawatthour) for a coal-fired power plant. ${ }^{211}$

\section{The Geysers}

The Geysers produces more electricity than any other geothermal energy field in the world. At the end of 1996, the installed nameplate capacity of the 22 generating units at The Geysers field was 1,837 megawatts. Of this capacity, 14 units totaling 1,224 megawatts were operated by Pacific Gas \& Electric Co. (PG\&E). The remainder was owned by five other companies, including the Calpine Corporation.

Electricity production had been on a slow but steady decline since the late 1980s, when it declined sharply in 1995 (Table 35 and Figure 25). Of the available capacity, some was not taken due to the relatively expensive nature of the electricity, and some was not taken due to reduced steam pressure within the KGRA.

\section{Production Decline at The Geysers}

\section{Economic Curtailment}

One of the major reasons for the production decline at The Geysers is economics. In 1996, California had surplus gas transmission capacity in the range of 1 to 2 billion cubic feet. With this much surplus capacity, the cost of off-peak gas-fired energy is essentially the cost of spot market gas. With recent spot prices roughly

Table 35. Annual Net Electricity Generation at The Geysers (Thousand Megawatthours)

\begin{tabular}{|c|c|c|c|c|}
\hline Year & PG\&E & SMUD GEO \#1 & Coldwater Creek & Total \\
\hline $1983 \ldots \ldots \ldots \ldots \ldots$ & 6,032 & 43 & - & 6,075 \\
\hline $1984 \ldots \ldots \ldots \ldots \ldots \ldots$ & 7,066 & 603 & - & 7,669 \\
\hline $1985 \ldots \ldots \ldots \ldots \ldots \ldots$ & 8,454 & 529 & - & 8,983 \\
\hline $1986 \ldots \ldots \ldots \ldots \ldots$ & 9,363 & 585 & - & 9,948 \\
\hline $1987 \ldots \ldots \ldots \ldots \ldots \ldots$ & 9,729 & 630 & - & 10,359 \\
\hline $1988 \ldots \ldots \ldots \ldots \ldots \ldots$ & 9,216 & 637 & 123 & 9,976 \\
\hline $1989 \ldots \ldots \ldots \ldots \ldots$ & 8,053 & 589 & 410 & 9,053 \\
\hline $1990 \ldots \ldots \ldots \ldots \ldots \ldots$ & 7,325 & 621 & 430 & 8,377 \\
\hline $1991 \ldots \ldots \ldots \ldots \ldots \ldots$ & 6,947 & 523 & 433 & 7,903 \\
\hline $1992 \ldots \ldots \ldots \ldots \ldots$ & 7,008 & 493 & 417 & 7,918 \\
\hline $1993 \ldots \ldots \ldots \ldots \ldots \ldots$ & 6,491 & 504 & 429 & 7,424 \\
\hline $1994 \ldots \ldots \ldots \ldots \ldots$ & 6,024 & 332 & 391 & 6,747 \\
\hline $1995 \quad \ldots \ldots \ldots \ldots \ldots \ldots$ & 3,774 & 447 & 385 & 4,606 \\
\hline
\end{tabular}

PG\&E $=$ Pacific Gas and Electric Company. SMUD = Sacramento Municipal Utility District.

Source: Energy Information Administration, Form EIA-759, "Monthly Power Plant Report."

\footnotetext{
${ }^{210}$ This assumption is based on the following formula: 3,412 Btu per kilowatthour $\times 1,024$ billion kilowatthours $/ 280,000$ people $=12.5$ million Btu per year per person for residential electricity $=34,000$ Btu per person per day $=10$ kilowatthours per person per day. For further details, see Energy Information Administration, Annual Energy Outlook 1996, DOE/EIA-0383(96) (Washington, DC, January 1996), Table A8, p. 94.

${ }^{211}$ Energy Information Administration, Emissions of Greenhouse Gases in the United States 1987-1994, DOE/EIA-0573(87-94) (Washington, DC, October 1995), Table A1, p. 76.
} 
Figure 25. Annual Net Generation from The Geysers, 1983-1995

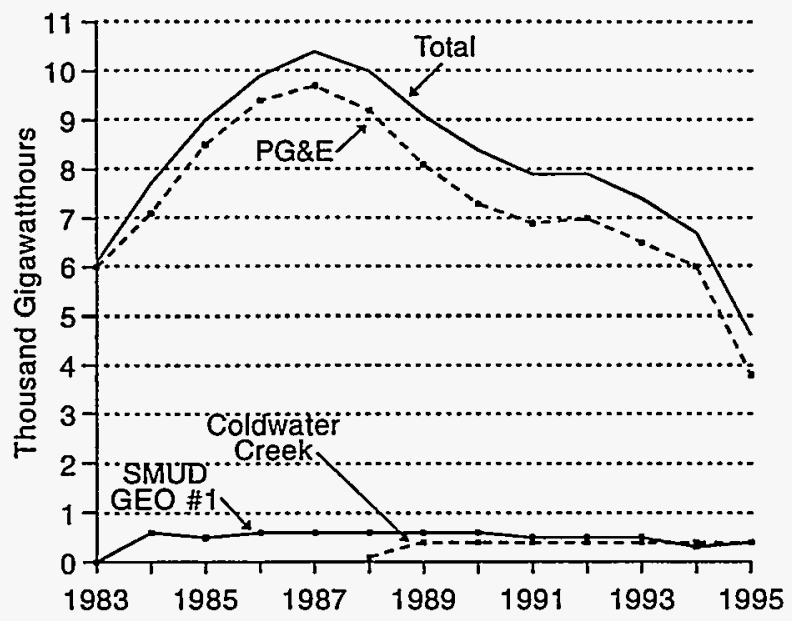

Source: Energy Information Administration, Form EIA-759, "Monthly Power Plant Report."

in the range of $\$ 1.50$ per million Btu, the fuel cost component of surplus gas-fired energy from a conventional steam plant (10,000 Btu per kilowatthour), is $\$ 15$ per megawatthour. If the marginal generation (not capacity) comes from a combined-cycle plant of only average efficiency (8,000 Btu per kilowatthour), the fuel cost component of the surplus gas-fired energy could be as low as $\$ 12$ per megawatthour. Marginal transmission charges off-peak are essentially zero. The small marginal cost of operations and maintenance for a steam or combined-cycle gas-fired power plant are insignificant.

Since the late 1980s (when steam production started to decline) surplus hydroelectric, coal-fired, and gas-fired electricity generation from throughout the West and Northwest have been available at prices much lower than those specified in some of PG\&E's power or steam purchase contracts (see Appendix E). In the past few years, surplus energy costs and prices have declined to the lowest levels in recent history. For example, average production costs for the Western Systems Coordinating Council averaged about \$16 per megawatthour in 1993 and 1994 and less than \$14 per megawatthour in 1995. In August 1996, nonfirm off-peak energy at the California-Oregon border was priced at about $\$ 12$ per megawatthour. Nonfirm on-peak energy was less than $\$ 18$ per megawatthour. (Prices vary daily by $\$ 1$ to $\$ 2$ per megawatthour or more.)

In contrast, a representative long-term geothermal electricity contract currently provides for firm capacity payments in the range of $\$ 156$ to $\$ 167$ per kilowatt per year and $\$ 130$ or more per megawatthour or more for associated energy-about 3 times and 8 to 10 times higher, respectively, than avoided costs for capacity and energy purchased separately. In these cases, PG\&E chooses maximum contractual or economic curtailment, whichever is greater.

Because of the availability of low-cost surplus energy and low-cost on-system generation, PG\&E has been renegotiating its geothermal steam supply contracts, which currently run from $\$ 130$ to $\$ 167$ per megawatthour. In August 1995, PG\&E and three of its steam suppliers at The Geysers entered into an agreement that lowered the price of generation from those steam supplies above the 40 percent of annual field capacity for which PG\&E has take-or-pay commitments. As a result of the discounted price, PG\&E increased generation at The Geysers over what it would have taken at the higher price. That agreement expired on December 31, 1995. The parties entered into a similar agreement for February 1996 and negotiated a discounted steam price agreement for the remainder of 1996.

Geothermal power that is generated near avoided cost or purchased on an avoided-cost basis would be curtailed only due to steam conditions and reservoir maintenance and stability requirements.

\section{Reduced Steam Pressure}

Venting of steam instead of reinjection of the condensed steam has led to the current reduced steam pressure at The Geysers. Figure 26 shows that steam production averaged about 240 billion pounds for $1987-89$ and about 195 billion pounds for 1992-94. On a peak-totrough basis (through 1994), steam production declined from 246 billion pounds in late 1987 to about 188 billion pounds in 1994. At the same time, the injection-production ratio increased from about 70 percent to about 90 percent. Without an increase in injection, production might have fallen more than it has.

PG\&E's consolidated capacity factor for The Geysers is projected to be approximately 35.8 percent of installed capacity in 1996, which includes economic curtailments, forced outages, scheduled overhauls, and projected steam shortage curtailments. The actual capacity factor in 1995 was 37.3 percent. Without take-or-pay contracts and contractual limits on curtailments, electricity production from The Geysers would have been considerably lower in recent years than was the case.

The effect of reduced steam flows on the economics of curtailment is twofold. First, reduced steam flows generate an absolute increase in fixed operations and maintenance costs and an increase in unit variable costs. Costs increase for reasons including reconfiguration of turbines, condensers, and gas control devices for low-load or low-pressure operations; extra maintenance 

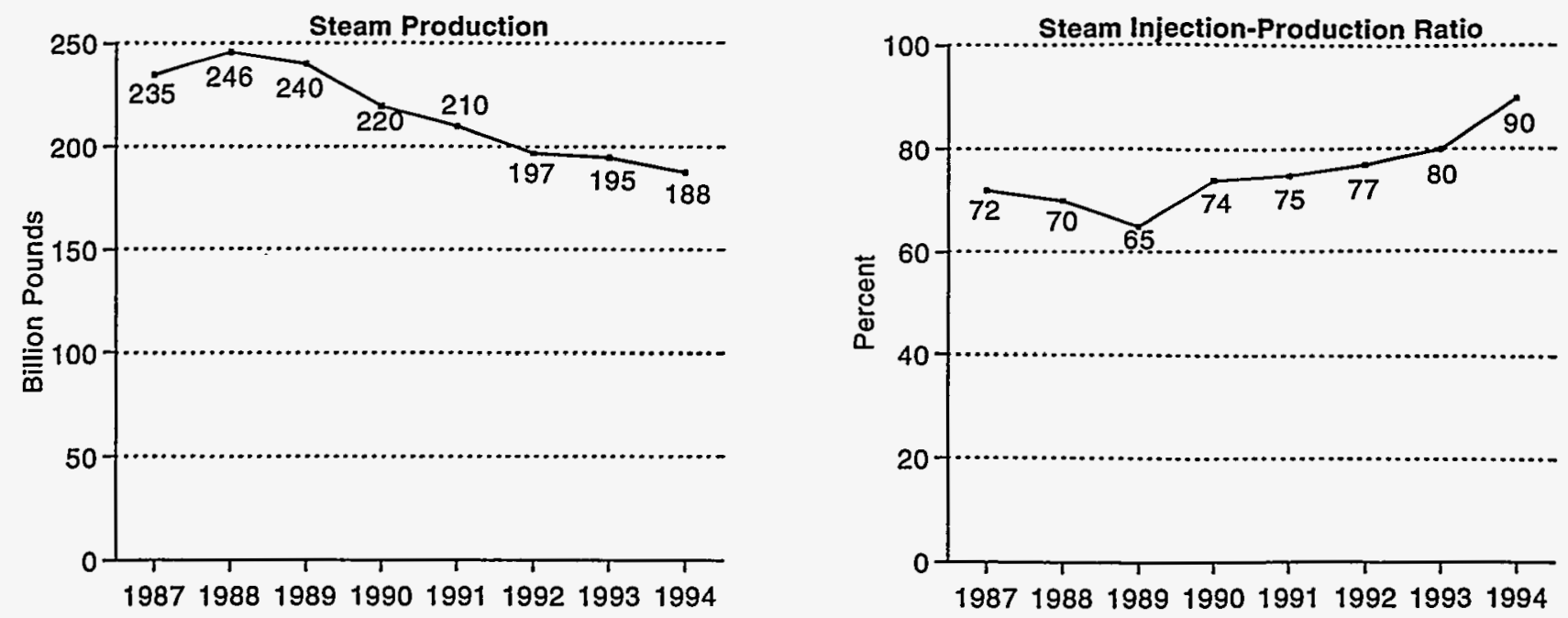

Source: The Geysers Geothermal Association, "An Update on The Geysers, November 1994," Geothermal Resources Council Bulletin, Vol. 24, No. 1 (January 1995), Figure 5, p. 9.

to address condensate and evaporative problems; and water injection system development. Unit variable costs increase because of water injection, control of noncondensible gases, fixed or semi-fixed staffing at reduced power levels, and other factors. Second, since steam flows are clearly declining, it makes no economic sense to extract the steam for use in nonfirm, low-value, off-peak generation.

Resource depletion at The Geysers KGRA continues to result from a series of decisions that generally were based on the assumption that the resource was infinite, or at least infinitely and rapidly replenishable. Starting as a hot spring resort and geyser tourist attraction during the California Gold Rush in 1849, the KGRA was surveyed and sized as a minable resource (i.e., an "open loop" system) after World War II. In the mid1950s, legislation authorized the State of California to auction geothermal energy rights to the few square miles of the KGRA to competing firms, in a manner somewhat parallel to the current auctioning of oil and gas rights in the Gulf of Mexico and off the continental shelves.

The local electric utility, PG\&E, contracted with each of the high-bidding corporations, agreeing to purchase a certain amount of electricity from each. Ownership of the various steam supply system components varied from contract to contract. This arrangement consistently gave neither the utility nor the corporations uniform incentives to conserve the steam, to use the steam efficiently, or to cooperate in preventing or curtailing resource depletion.
The first energy extraction systems were designed to be open, venting water vapor and heat. The condensed water vapor was allowed to flow into existing waterways or was evaporated. Reinjection began much later, and a few plants still do not reinject remaining fluids. There were and still are no consistent disincentives for inefficiencies; on the other hand, there have been incentives to tap as much as needed by some, but not all, firms, in order to generate the contractually agreed upon electricity. However, without a prior binding agreement by KGRA users to cooperate in the event of a resource shortage, and without a legislated solution, field depletion will continue.

In the early 1980s, it became increasingly apparent that The Geysers could be depleted simply by mining. A change in thinking occurred, to making 30-year estimates of resource utilization, rather than the amount that could be exploited in the near term.

\section{Halting Pressure Declines by Well Injection}

In 1989, Calpine and the Northern California Power Agency (NCPA) started a joint injection program. The two organizations control a total of 198 wells, 10 power plants, and 325 gross megawatts of capacity, all in the southeastern portion of The Geysers KGRA. The flow rate of wells surrounding Calpine CA956A-1, one of the wells converted from production to injection in 1989, had been declining at an exponential rate of about 26 percent during 1988 and 20 percent during 1989 until 
injection began in late 1989. ${ }^{212}$ Injection had the effect of slowing the decline in the remaining 12 production wells to an exponential rate of about 10.5 percent. Combining Calpine's CA956A-1 and the NCPA's nearby C-11 well, the two organizations are injecting roughly 1,500 gallons per minute. Within 5 months, steam flow at 25 nearby wells increased, resulting in 20 megawatts more power and a drop in noncondensible gases.

Because of the demonstrated value of water injection in slowing steam flow declines, several well owners have increased injection or have planned injection programs. The major injection program is the Southeast Geysers Pipeline Project, which involves the construction of a 20-inch-diameter, 29-mile-long pipeline with a capacity of 5,400 gallons per minute (7.8 million gallons per day). The pipeline will carry water from a wastewater treatment facility north of The Geysers for injection into the steam reservoir in the southeastern portion of the KGRA. It is designed primarily to support NCPA's two plants (247 megawatts) and four of PG\&E's plants (495 megawatts).

Construction began in October 1995, and the pipeline is scheduled to begin operation in 1997. A sustainable increase in capacity of 50 to 70 megawatts is expected. The pipeline is estimated to cost about $\$ 45$ million, ${ }^{213}$ including $\$ 7.2$ million from the U.S. Department of Energy, but including neither the estimated $\$ 7$ million required to move the water from the KGRA's boundary to the injection sites nor the additional water treatment facility needed before the water enters the pipeline. While the cost of construction for the first pipeline and pumping systems may be high, the value of a small, but potentially environmentally benign, waste effluent disposal system is seen as a benefit and, therefore, a partial cost offset.

\section{Halting Pressure Declines by Cycling Operations}

In 1988, NCPA was the first operator at The Geysers to switch from baseload operations to cycling operations. The switch was designed to slow the decline in steam production from the field. NCPA's generating units are rated at 247 megawatts, but production was reduced to 150 megawatts. Tests in June 1993 showed that the plants are capable of sustained operations up to 221 megawatts.

PG\&E began cycling its units in August 1994. Between August 1994 and May 1996, PG\&E deferred 3,500 gigawatthours of geothermal energy. PG\&E's reasons for cycling were partly technical (to maintain steam flow) and partly economic (to substitute lower cost hydroelectric, coal-fired, or gas-fired energy). In 1995, PG\&E curtailed or completely avoided production from some of its units at The Geysers for as much as 5 months, because it could economically dispatch nongeothermal units instead. The combination of large winter snow runoff and low-cost natural gas led to a substitution of hydroelectric and gas-fired energy for almost 2,000 gigawatthours of geothermal energy. PG\&E estimated that deferred geothermal generation would approach 2,000 gigawatthours in 1996. For a point of reference, a power plant rated at 228 megawatts and operating at 100 percent capacity factor can generate 2,000 gigawatthours per year.

Cycling geothermal wells, however, causes some operational problems. Among the problems are thermal cycling of steam within well bores, water collection in steam gathering systems, water carryover to steam separators and turbines, increased wear and maintenance requirements, and an increase in noncondensible gases when generation is increased.

When production is curtailed or shut down, plant operators often have to close in wells to comply with air emission regulations. Closing the wells allows steam in the well bore to condense, resulting in thermal cycling of the wells (not the power plants). This thermal cycling can damage the well and create flow problems when operations resume. Modified operating practices, such as targeting minimum field-wide steam flows and setting limits on the duration that wells are in no-flow conditions, have lessened but have not eliminated this problem.

Condensation in low-flowing or nonflowing well bores allows noncondensible gases to build up near the well bore. When the wellhead control valve is opened and the gases pass through the gathering system to the generating station, the condenser or abatement system can quickly become overloaded, resulting in reliability or environmental compliance problems. Changes in noncondensible gas concentrations in The Geysers appear to be correlated with changes in injection strategy; injecting water correlates with decreases in noncondensible gases, while shutting in an injection well correlates with increases in noncondensible gases. In the southeastern portion of The Geysers KGRA, where noncondensible gases have been increasing despite aggressive injection programs, the decline in reservoir pressure appears to have been large enough to offset the beneficial effects of injection.

\footnotetext{
${ }^{212}$ The Geysers Geothermal Association, "An Update on The Geysers, November 1994," Geothermal Resources Council Bulletin, Vol. 24, No. 1 (January 1995), Figure 7, p. 17.

${ }^{213}$ U.S. Department of Energy, Office of Energy Efficiency and Renewable Energy, Geothermal Division, FY 1996 Program Summary.
} 
Condensation within the steam gathering system under low-steam or no-steam conditions creates a risk of water carryover to the steam separators and turbines when production resumes. This problem can be controlled to some extent by increased monitoring of the steam field and the use of extra moisture traps or drop pots, but the problem has not been eliminated.

Cycling operations also increase wear and tear on the equipment and systems (e.g., stuck valves). In some cases, evaporation from the cooling tower is greater than the amount of condensate from the steam flow. Running only a few cooling tower fans at a plant can ease this problem.

\section{Lessons Learned}

Some owners and operators of power plants at The Geysers have learned that the resource must be intensively managed rather than mined for steam. The notion of an inexhaustible thermal resource (within the bounds of existing extraction and generating capability) has been clearly proven incorrect. Since the late 1980s, when the steam decline became both noticeable and sustained, six plants, totaling approximately 200 megawatts, have been retired or suspended. Most other plants have been effectively derated due to declining steam production. Reinjection of consumed steam has been successful in slowing steam declines but thus far has not been shown to increase steam production to the levels that prevailed in the late 1980s.

Through the 1980s, production drilling activities were often designed to find new steam. Since that time, drilling activity has declined sharply, and the objective of drilling campaigns has shifted toward a goal of more economical exploitation of existing steam sources (e.g., via double- and triple-forked bottoms from a single hole). Older wells are also under consideration for deepening. Many of the oldest wells are relatively shallow, and extending the borehole by several thousand feet at an existing plant is a small expense in relation to the potential for a more robust steam resource.

In the past few years, the major plant owners have bought or are planning to buy new turbines and steam paths designed to operate at turbine inlet pressures less than 100 pounds per square inch gauged (psig), for which most of the units at The Geysers were originally designed. Most operators are considering main steam line pressures down to 50 psig. Operators are also modifying the design and operations of existing turbines, condensers, and gas handling systems for lowload and cycling operations. These changes promise to extend the life of the resource but at a higher cost than was the case in the 1980 s.

Thus, the combination of rising costs, reduced steam flows, and abundant low-cost energy from conventional generation means that The Geysers will increasingly become a cycling resource with selective system and resource upgrades. The days of unlimited extraction at rated power plant output and of large-scale in-fill drilling are over.

Outside The Geysers, the geothermal electricity generation industry has watched this series of events intently, and has responded by constructing closed-cycle systems that reinject virtually everything that comes out of the ground, including the residual heat. Binary and dualflash heat extraction systems are the only ones being installed anywhere in the world today; the paradigm of "steam mining" has been replaced with the recognition that these geothermal resources have finite flows and capacities but, with proper management, can be sustained indefinitely.

Also, development to the limits of the capacities estimated for other KGRAs is being approached more cautiously than before, so as to avoid a scenario similar to the one at The Geysers. Competition between corporations working within the same KGRA as a result of State or Federal auctions has eased as a result of ownership consolidation and changing auction strategies. Wells in new developments are being spaced further apart; each resource is being tapped to only a fraction of its estimated sustainable potential; and water resources are being examined carefully for sufficiency of flow and quantity, water chemistry, and tendencies toward brine and scaling.

A paradigm shift seems to have been implemented, though not completed. While vapor-dominated hydrothermal resources were once viewed and engineered as unlimited, they are now understood as finite resources requiring prudent management to sustain them. There is no evidence worldwide of the steam mining paradigm's continued acceptance at developing sites. 


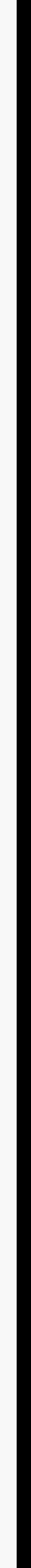


Section IV

\section{International Renewable Energy: Current Status and Prospects}





\section{International Renewable Energy}

\section{Overview}

As many as 2 billion people still have no access to electricity. ${ }^{214}$ Most of them live in countries located in tropical and subtropical areas, with greater availability of renewable resources (e.g., higher levels of solar energy) than developed countries. Many of these same countries lack much of the basic power grid infrastructure that developed countries built at considerable expense. In such cases, the flexibility and small size of renewable systems such as solar thermal, photovoltaics, and wind can be ideal. Another advantage associated with small size is speed of construction. Wind farms, for instance, can take less than a year to build. Also, the smaller capacity of renewable plants allows them more easily to match incremental changes in load growth and to meet the requirements of small load centers.

The world market for renewable energy production systems (excluding hydroelectricity) is estimated to be about $\$ 1$ billion during the decade from 1990 to 2000 .

Although renewable energy use has risen all over the world, it is estimated that developing countries (excluding Eastern Europe and the former Soviet Union) generate only 0.3 percent of their electricity from renewables.

This chapter updates information presented in the Renewable Energy Annual 1995. Overviews of worldwide renewable energy developments are presented below by type of energy source. The renewables covered in this section are wind, photovoltaic (PV), geothermal, biomass, and municipal solid waste (MSW).

\section{Wind}

\section{Status of the Worldwide Wind Energy Market}

Worldwide, wind-generated electricity grew by more than 20 percent in 1994 with the installation of 25,000 new wind turbines, or roughly 611 megawatts of capacity. About 93 percent of the wind systems installed in 1994 were outside the United States, with the largest increases in Germany, India, and the United Kingdom. Table 36 shows wind capacity additions in 1995 and projected additions through 2010 for the top 15 countries in terms of wind energy capacity. Although U.S.made wind technology is on a par with that of any other country, with few exceptions, U.S. utilities have not invested in the latest wind technologies as much as their foreign counterparts in the three countries mentioned.

In 1995, worldwide wind-powered generating capacity was 4,900 megawatts. ${ }^{215}$ The additional worldwide capacity of wind turbines installed in 1995 was 1,289 megawatts. Most of this capacity was installed in Europe. In Asia and the Pacific, 95 percent of new installations in 1995 were in India, while China accounted for 14 megawatts. The total wind energy potential of China is estimated at 250,000 megawatts. The cumulative installed capacity in the United States fell by 14 megawatts in $1995 .{ }^{216}$

The world's cumulative installed wind capacity is fast approaching 5 gigawatts. ${ }^{217}$ Table 37 shows the continental shares of world wind power generation, which is about 10 terawatthours. ${ }^{218}$ Because of continual improvements in design, manufacturing, materials, and electronic controls, wind farms of large wind turbines are now capable of producing electricity for as little as 4 cents per kilowatthour, in locations with good wind conditions.

The state-owned and newly privatized utilities in Latin America are beginning to show interest in wind energy. It is estimated that there may be as much as 250 megawatts of wind capacity on line in the region by the late 1990 s. $^{219}$ The current size of the market is about $\$ 250$ million, and it is attracting U.S. wind technology companies in search of new projects in view of the slow

\footnotetext{
214"The Future of Energy: The Battle for World Power," The Economist, Vol. 337, No. 7935 (October 7, 1995$),$ p. 23.

${ }^{215}$ International Energy Agency, Wind Energy Annual Report 1995 (Paris, France, March 1996), p. 20.

${ }^{216}$ This decrease is based on the total reported wind capacity of 1,731 megawatts, which excludes 6.6 megawatts of utility capacity and 35 megawatts of nonutility capacity that were not captured by EIA sources.

${ }^{217}$ W. Sweet, "Technology 1996: Power and Energy," IEEE Spectrum, Vol. 33, No. 1 (January 1996), pp. 70-75.

${ }^{218}$ Paul Gipe \& Associates, "1996 Overview of Wind Generation Worldwide," web site keynes.fbi2.tu-berlin.de/luftraum/konst/ overview.html (August 26, 1996).

${ }^{219}$ P. Gipe, "Southern Stirrings," Independent Energy, Vol. 26, No. 3 (April 1996), pp. 39-40.
} 
Table 36. Installed Wind Capacity and Projected Capacity Additions for Selected Countries (Megawatts)

\begin{tabular}{|c|c|c|c|}
\hline \multirow[b]{2}{*}{ Country } & \multicolumn{3}{|c|}{ Capacity } \\
\hline & Installed in 1995 & Cumulative Through December 1995 & Projected Through 2010 \\
\hline Argentina $\ldots \ldots \ldots \ldots$ & - & - & $100-300$ \\
\hline Australia..$\ldots \ldots \ldots \ldots$ & - & - & $50-75$ \\
\hline Chile $\ldots \ldots \ldots \ldots \ldots$ & - & - & $100-200$ \\
\hline China $\ldots \ldots \ldots \ldots \ldots$ & 14 & 44 & $350-600$ \\
\hline Denmark $\ldots \ldots \ldots \ldots$ & 98 & 637 & - \\
\hline Germany $\ldots \ldots \ldots \ldots$ & 500 & 1,132 & $200-350$ \\
\hline Holland $\ldots \ldots \ldots \ldots$ & 95 & 249 & - \\
\hline India $\ldots \ldots \ldots \ldots \ldots$ & 375 & 576 & $700-1,200$ \\
\hline Italy $\ldots \ldots \ldots \ldots \ldots$ & 11 & 33 & - \\
\hline Mexico $\ldots \ldots \ldots \ldots$ & 一 & - & $150-300$ \\
\hline New Zealand...$\ldots \ldots$ & - & 一 & $50-100$ \\
\hline Spain ............. & 58 & 133 & $150-250$ \\
\hline Sweden ........... & 29 & 69 & - \\
\hline United Kingdom $\ldots \ldots$. & 40 & 201 & $100-300$ \\
\hline United States $\ldots \ldots \ldots$. & - & $a_{1,731}$ & ${ }^{b} 659$ \\
\hline
\end{tabular}

${ }^{a}$ Excludes 6.6 megawatts of utility capacity and 35 megawatts of nonutility capacity that were not captured by EIA sources.

bPlanned through 2003.

$-=$ not available.

Sources: Foreign: Paul Gipe \& Associates, "1996 Overview of Wind Generation Worldwide," web site keynes.fb12.tu-berlin.de/ luftraum/konst/overview.html (August 26, 1996); and S. Kidney, "U.S. Wind Energy Firms Look Overseas," Energy Extra (August 10, 1995). United States: Installed and Cumulative Capacity-Energy Information Administration, Electric Power Annual 1995, Vol. 2, DOE/EIA-0348(95/2) (Washington, DC, December 1996), pp. 15-16. Projected Capacity—U.S. Department of Energy, Office of Energy Efficiency and Renewable Energy, "Wind Energy Data: Monthly Summary Report" (September 1996).

Table 37. Continental Shares of World Wind Power Generation, 1995

\begin{tabular}{c|c}
\hline \multicolumn{1}{c|}{ Continent } & Percent Share \\
\hline Asia $\ldots \ldots \ldots \ldots \ldots \ldots \ldots \ldots \ldots \ldots \ldots \ldots \ldots \ldots \ldots \ldots \ldots \ldots \ldots \ldots$ & 7 \\
Europe $\ldots \ldots \ldots \ldots \ldots \ldots \ldots$ & 52 \\
North America $\ldots \ldots \ldots \ldots \ldots$ & 40 \\
South America and Africa $\ldots \ldots \ldots$ & 1 \\
\hline
\end{tabular}

Source: Paul Gipe \& Associates, "1996 Overview of Wind Generation Worldwide," web site keynes.fb12.tu-berlin.de/ luftraum/konst/overview.html (August 26, 1996).

U.S. market. In addition to wind systems, hybrid systems combining wind and solar technologies are attractive for rural electrification projects in remote areas far from the power grid.

\section{Photovoltaics}

Annual shipments of PV cells have climbed from next to nothing in the early 1970 s to more than 75 megawatts today. ${ }^{220}$ In the past 10 years, PV sales worldwide have more than quadrupled, while installed costs have dropped by more than half. ${ }^{221}$ The rapid decline in PV costs and the development of niche markets have increased PV demand at a rate of 15 to 20 percent a year.

PV manufacturers in the United States are currently exporting about two-thirds of their production (or about 20 megawatts) (Table 38). ${ }^{222}$ The recent surge in U.S. PV exports has occurred for the following reasons:

- A weaker dollar (mainly against the Deutsche Mark and Yen) in 1994 and 1995 made U.S. PV systems more attractive overseas than similar Japanese or German systems.

\footnotetext{
${ }^{220}$ W. Sweet, "Technology 1996: Power and Energy."

${ }^{221}$ J. Casey, "Here Comes the Sun," Civil Engineering (October 1995), p. 54.

${ }^{222}$ Personal communication between Gabriel Sanchez, Science Applications International Corporation, and Clay Aldritch, Solar Industry Association (September 10, 1996).
} 
Table 38. Destination of U.S. Photovoltaic Cell and Module Export Shipments by Country, 1995

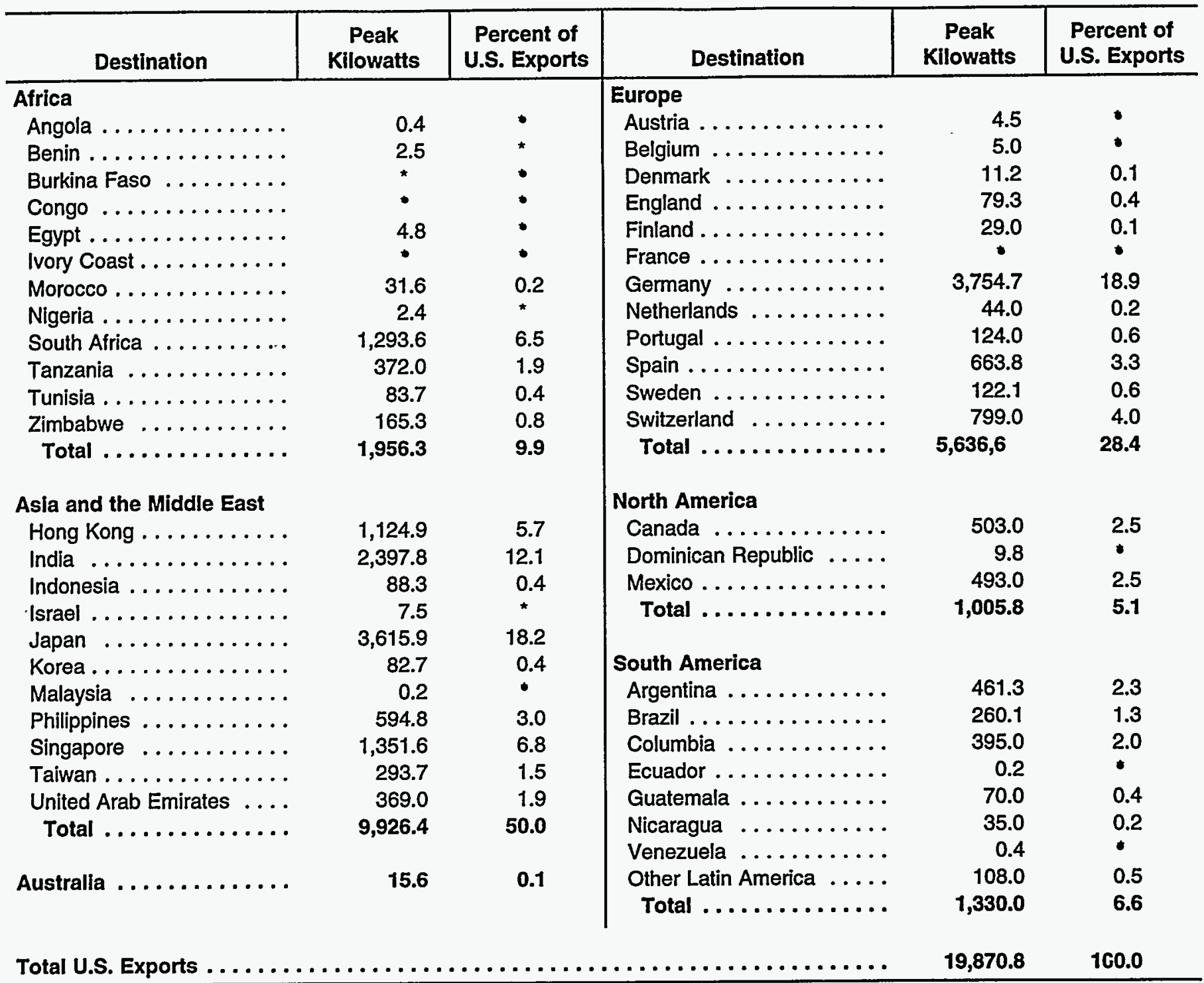

- = Less than 500 peak watts or less than 0.05 percent.

Note: Totals may not equal sum of components due to independent rounding.

Source: Energy Information Administration, Form EIA-63B, "Annual Photovoltaic Module/Cell Manufacturers Survey."

- Higher costs of electricity production than in the United States make PV installations more competitive.

- The level of U.S. PV technology is considered abroad to be at least equal to its nearest competitors.

- Japan is the second-largest market, next to Germany, for U.S. PV exports, and demand there is still rising. Japan's domestic producers are not able to satisfy demand and are also at a price disadvantage relative to their U.S. counterparts. Another example is Germany, where demand for PV imports has risen over the past few years but is now flattening.
- In developing countries, demand has risen significantly, fueled by the recognition that PV systems are an attractive option for rural electrification in isolated, inaccessible communities that are distant from the power grid and have small electricity requirements. Examples include rural electrification in Kenya, South Africa, and Indonesia. Purchases of PV systems from the United States and other sources have been facilitated by the increased interest of multilateral banks, such as the World Bank, in actively financing $P V$ and other renewable projects.

- The demand for PV systems has risen considerably over the past few years in developed countries. Many governments actively support PV expansion 
through subsidies, funding for research and development, tax incentives, information dissemination, and installation on public facilities. The best example is Japan's New Energy and Industrial Technology Development Organization (NEDO), which has encouraged the use of PV systems.

\section{Photovoltaics Projects in Japan}

Japan's Ministry of International Trade and Industry (MITI) adopted in December 1994 the Basic Guidelines for New Energy Introduction, which are aimed at strengthening energy security and positively contributing to environmental protection measures such as $\mathrm{CO}_{2}$ emission control. The following measures have been instituted to ensure progress toward the objectives of the guidelines: expansion of the subsidy system for early establishment of a self-sustaining PV market; establishment of a subsidy system for local governments involved in intensive and large-scale introduction of new energy technologies; and other increases in the budget to finance new energy development promotion. The promotion program for PV technologies will contain the following market-enhancing projects: ${ }^{223}$

- Promotion of Residential PV Systems. To speed up establishment of a self-sustaining residential PV market, subsidies to individuals installing PV systems on detached houses or in housing developments will be increased. Imported PV systems as well as those made in Japan are eligible for the subsidies.

- PV Power Generation Field Tests in Public Facilities. In order to collect operational data and prepare the groundwork for general PV introduction, PV equipment will be installed in museums, schools, citizens' halls, and other public facilities. Imported systems are eligible.

- Development of Energy-Efficient Silicon Manufacturing Technology. To accommodate predicted future growth in solar cell demand and rationalize energy use in manufacturing, energy-efficient and low-cost mass production technologies will be developed for solar-cell-grade silicon.

- Development of System Application Technology. To achieve substantial system cost reductions in the New Sunshine project, research and development will focus on amorphous and other thin-film devices and super-high-efficiency device manufacturing technologies.
- International Joint Development and Demonstration. To improve the reliability of different types of systems, system application technologies will be developed in cooperation with developing nations. A new joint demonstration project is planned in an Asian country in 1997.

Successful individual and collective candidates for the 1996 Residential PV Monitor Program and NEDO PV Field Test were decided in September 1996. The number of applications exceeded 10,000 for the first time. Significant price reductions, printed and electronic media reporting, national explanatory meetings, and consistent business efforts at manufacturers and sales outlets have increased public awareness of PV technology over the last 2 years.

\section{Major Projects in Other Countries ${ }^{224}$}

Brazil. Five hundred PV-powered battery charging stations are expected to be installed in Brazil by Golden Photon. More than $\$ 17$ million worth of the "Electricworks" PV stations are planned; each system will supply 40 to 50 families with recharging service for batteries, which then can be used to power one or two high-efficiency lights, a radio or television, and other appliances. Owner-operators of the systems can charge batteries for surrounding residents for the equivalent of what these people are now spending on kerosene, candles, and dry cell batteries, the firm said.

Britain. One hundred schools and colleges throughout Great Britain will receive 1-kilowatt PV arrays within the next 3 years under a program funded by the U.K. government. Called the "Scolar Programme," the program was selected by the government's Foresight Initiative to receive $\notin 1$ million; each participating school must contribute about $£ 3,500$ for the PV system. The Scolar Programme was the idea of Philip Wolfe, managing director of Intersolar Group, a PV cell producer in the U.K. The Foresight Initiative aims at supporting important British technologies needed in the next 10 years.

Australia. PV-powered radio signaling and communication systems have been installed along a $426-\mathrm{km}$ (265mile) railway between Port Hedland and Newman in Western Australia. The 54 PV systems replace wind and diesel hybrids removed due to high maintenance costs. Now the signaling, early warning detection, locomotive, and ore care monitoring systems are all linked to a central computer that displays operating status. The

\footnotetext{
${ }^{223}$ O. Ikki, "PV Activities in Japan," Resources Total System Co., Ltd., Monthly Nerwsletter (June-October 1996); and personal communication between James Holihan, Energy Information Administration, and Osamu Ikkj (October 1996).

${ }^{224}$ Information derived from Utility Photovoltaic Group, PV Vision, Vol. 4, No. 2 (1996), p. 6.
} 
railway-owned and maintained by BHP Steel-is the largest privately owned railway in Australia.

Indonesia. Indonesia has begun a major national program to put renewable energy sources into its next planning cycle, reports $P V$ News. More than 10,000 solar home systems were installed before 1991; 1 million rural solar homes is the stated goal for a 50-peakmegawatt PV program launched in 1992 and currently being implemented. The goal of the project is to provide electricity to 1 million households-about 10 percent of the 10 million rural families without electricity-by 2005 . In addition to the 50-megawatt solar homes project, a program to improve remote health centers has been proposed. PV will be used to power vaccine refrigerators, freezers, and lighting under this $\$ 31$ million program.

India. India is the largest PV market in the world today. According to the National Renewable Energy Laboratory, nearly 10 megawatts of PV modules are projected to be installed during 1996. A recent drop in the interest rate (from 10.3 percent to 2.5 percent) from a U.S. $\$ 42$ million grant from the World Bank in 1991 for PV market development has done much to stimulate the situation. A decrease in import duties during this time and increased production of cells and modules have resulted in a reduction in module prices from 225 rupees per watt in 1991 to 165 rupees per watt today. Recently, the World Bank agreed in principle to establish a $\$ 200$ million second line of credit for the Indian Renewable Energy Development Agency (IREDA). For the first time, IREDA is providing foreign-exchange risk cover of 6 percent.

\section{Geothermal}

Table 39 shows the recent and projected installed geothermal electricity generation capacity of the world's 21 countries that have developed commercial geothermal energy resources.

Table 39. Installed Geothermal Electricity Generation Capacity by Country, 1990, 1995, and 2000 (Megawatts)

\begin{tabular}{|c|c|c|c|}
\hline Country & 1990 & 1995 & 2000 \\
\hline Argentina $\ldots \ldots \ldots \ldots \ldots \ldots \ldots \ldots$ & 0.67 & 0.67 & NA \\
\hline Australia..$\ldots \ldots \ldots \ldots \ldots \ldots \ldots$ & 0.00 & 0.17 & NA \\
\hline China..$\ldots \ldots \ldots \ldots \ldots \ldots \ldots \ldots \ldots$ & 19.20 & 28.78 & 81 \\
\hline 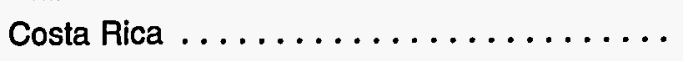 & 0.00 & 55.00 & 170 \\
\hline 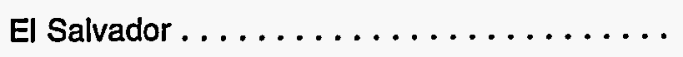 & 95.00 & 105.00 & 165 \\
\hline France $\ldots \ldots \ldots \ldots \ldots \ldots \ldots \ldots \ldots$ & 4.20 & 4.20 & NA \\
\hline Greece $^{a} \ldots \ldots \ldots \ldots \ldots \ldots \ldots$ & 0.00 & 0.00 & NA \\
\hline Iceland $\ldots \ldots \ldots \ldots \ldots \ldots \ldots \ldots$ & 44.60 & 49.40 & NA \\
\hline Indonesia $\ldots \ldots \ldots \ldots \ldots \ldots \ldots \ldots$ & 144.75 & 309.75 & 1,080 \\
\hline Italy $\ldots \ldots \ldots \ldots \ldots \ldots \ldots \ldots$ & 545.00 & 631.70 & 856 \\
\hline 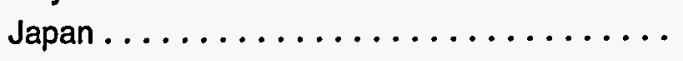 & 214.60 & 413.70 & 600 \\
\hline Kenya $\ldots \ldots \ldots \ldots \ldots \ldots \ldots \ldots \ldots \ldots$ & 45.00 & 45.00 & NA \\
\hline 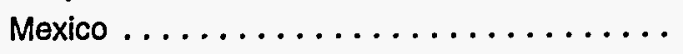 & 700.00 & 753.00 & 960 \\
\hline New Zealand $\ldots \ldots \ldots \ldots \ldots \ldots$ & 283.20 & 286.00 & 440 \\
\hline Nicaragua $\ldots \ldots \ldots \ldots \ldots \ldots \ldots$ & 35.00 & 35.00 & NA \\
\hline Philippines $\ldots \ldots \ldots \ldots \ldots \ldots \ldots \ldots$ & 891.00 & $1,191.00$ & 1,945 \\
\hline Portugal $^{b} \ldots \ldots \ldots \ldots \ldots \ldots \ldots \ldots$ & 3.00 & 5.00 & NA \\
\hline Russia $\ldots \ldots \ldots \ldots \ldots \ldots \ldots \ldots \ldots$ & 11.00 & 11.00 & 110 \\
\hline Thailand $\ldots \ldots \ldots \ldots \ldots \ldots \ldots \ldots$ & 0.30 & 0.30 & NA \\
\hline Turkey $\ldots \ldots \ldots \ldots \ldots \ldots \ldots \ldots \ldots$ & 20.60 & 20.60 & 125 \\
\hline United States $\ldots \ldots \ldots \ldots \ldots \ldots \ldots$ & $2,774.60$ & $2,816.70$ & 3,395 \\
\hline World Total $\ldots \ldots \ldots \ldots \ldots \ldots \ldots$ & $5,831.72$ & $6,761.98$ & 9,927 \\
\hline
\end{tabular}

${ }^{\mathrm{a} G r e e c e}$ has shut down its 2.0-megawatt Milos pilot plant.

$\mathrm{b}$ Including the Azores Islands.

$\mathrm{NA}=$ not available.

Source: International Geothermal Association, "Installed Geothermal Electricity Generation Capacity by Country and Year," web site www.demon.co.uk/geosciligahome.html (August 28, 1996). 


\section{Biomass: Wood and Charcoal Energy}

Worldwide, annual average biomass fuel consumption totaled almost 14 quadrillion Btu over the period 19851990 (Table 40). Firewood and charcoal are important biomass fuels in many parts of the world. Urban populations in developing countries create strong demand for charcoal due to the advantages listed in Table 41. In sub-Saharan Africa, charcoal is a $\$ 2.5$ billion per year industry and a significant factor in agricultural employment. Wood input of 31 million metric tons oil equivalent is used to produce 11 million metric tons oil equivalent of charcoal. By comparison, 100 million tons

Table 40. Biomass Fuel Consumption and Production, 1985-1990

\begin{tabular}{|c|c|}
\hline Region & $\begin{array}{l}\text { Biomass Fuel } \\
\text { Production and } \\
\text { Consumption } \\
\text { (Quadrillion Btu) }\end{array}$ \\
\hline North America $\ldots \ldots \ldots \ldots$ & 3.63 \\
\hline Europe .............. & 0.99 \\
\hline Nordic Countries . . . . . . . . . & 0.24 \\
\hline EEC $\ldots \ldots \ldots \ldots \ldots \ldots$ & 0.23 \\
\hline Central Europe . . . . . . . . . & 0.03 \\
\hline Southern Europe $\ldots \ldots \ldots \ldots$ & 0.33 \\
\hline Eastern Europe $\ldots \ldots \ldots \ldots$ & 0.16 \\
\hline Africa $\ldots \ldots \ldots \ldots \ldots \ldots$ & 2.10 \\
\hline Asia $\ldots \ldots \ldots \ldots \ldots \ldots$ & 4.40 \\
\hline Latin America . . . . . . . . . . & 1.50 \\
\hline Oceana $\ldots \ldots \ldots \ldots \ldots$ & 0.10 \\
\hline
\end{tabular}

Source: D.A. Tillman, The Combustion of Solid Fuels and Wastes (New York, NY: Academic Press, 1991), p. 66. oil equivalent of firewood is consumed, reflecting a $\$ 500$ million per year industry. ${ }^{225}$ However, charcoal production is inefficient in some parts of the world and requires three to four times its weight in wood input to produce.

In African countries, much of the raw material for charcoal manufacturing is ancillary to forest clearing. Therefore, an equivalent yolume of wood is not replanted, and a net addition of carbon dioxide and methane to atmospheric inventories occurs. Regulation of charcoal production in developing countries has been difficult and inadequate. Reasons for this include lack of organizational capacity of governments to regulate, lack of coordination between government agencies, and arbitrary interventions into markets. ${ }^{226}$ Improvements in government policy and tightening of regulatory practices represent administrative challenges. On the technical level, design changes in production kilns and residential stoves offer avenues to environmental and efficiency improvements. Inverted draft chimney designs and other refinements can improve kiln efficiencies by about a factor of four.

The World Bank has sponsored programs in recent years to promote the use of improved residential charcoal stoves. On an industrial scale, the World Bank is promoting the use of Casamance kilns (improved design and efficiency) in charcoal making.

\section{Municipal Solid Waste}

Europe is ahead of the rest of the world in terms of MSW utilization. Over 27 million metric tons of solid waste are used to generate electricity and for heating in Europe. Several countries in Europe already recover

Table 41. Advantages and Disadvantages of Charcoal as a Source of Energy

\begin{tabular}{l|l}
\hline \multicolumn{1}{c|}{ Advantages } & \multicolumn{1}{c}{ Disadvantages } \\
\hline - Burns without smoke. & - Poorly engineered kilns have production efficiencies of only 8 to 9 percent \\
- Stores well. & and cause environmental harm. \\
- Burns without flames. & - Inefficient stoves have efficiencies of only $20-35$ percent. \\
- Used in simple, cheaper stoves. & - Non-closed-loop sources of wood add to world carbon dioxide and \\
- One-fourth to one-half the price of fossil fuels. & methane inventories. \\
& $\begin{array}{l}\text { - Related government policy in some countries has been ineffective and } \\
\text { poorly coordinated. } \\
\text { - Demand growth in some countries has been steady while prices have } \\
\text { remained flat, limiting capital for process improvements. }\end{array}$ \\
\hline
\end{tabular}

Source: Based on R. van der Plas, The World Bank Group, "Burning Charcoal Issues," FPD Energy Note No. 1, web site www.worldbank.org (April 1995).

\footnotetext{
${ }^{225}$ Per telephone conversation between Robert Lowe, Energy Information Administration, and Willem Floor, World Bank, October 30, 1996.

${ }^{226}$ All information on biomass to this point in this section was based on Robert van der Plas, The World Bank Group, "Burning Charcoal Issues," FPD Energy Note No. 1, web site www.worldbank.org (April 1995).
} 
energy from waste; for example, Switzerland requires all incinerators to be equipped for energy output and is adding 10 new plants. Sweden now processes almost 1.5 million metric tons of MSW each year. Currently, the Netherlands targets 40 percent energy recovery from waste. In Brussels, Belgium, MSW thermal recovery processes supply more than 5 percent of electricity. In France, 25 percent of the total MSW is incinerated for energy production. ${ }^{227}$

\section{Overviews of Renewable Energy Status by Region}

\section{Africa}

The development of renewable resources in Africa has been impeded by barriers to the availability of financing and resources. In the area of PV, however, African nations have made considerable advances. For instance, in Kenya, a series of rural electrification and other programs has resulted in the installation of more than 20,000 small-scale PV systems since 1986. ${ }^{228,229}$ These PV systems now play a prominent role in decentralized, sustainable electrification.

Other examples of PV use in Africa are as follows:

- A program to supply PV systems to 100 rural homes began in Namibia in April 1996.

- A Norwegian engineer built a cheap, self-contained, village-sized PV desalination plant in Massawa, Eritrea, in late $1995 .^{230}$

- The Independent Development Trust, a rural electrification project in South Africa, has installed PV systems for clinics in remote areas.

Table 42 shows an assessment, by a consortium of nonprofit industry trade associations, of renewable energy resources and market potential in South Africa and Asia.

\section{The Americas}

Table 43 shows an assessment, by a consortium of nonprofit industry trade associations, of renewable energy resources and market potential in the Americas. The following sections focus on three representative countries: Canada, Costa Rica, and Mexico.

\section{Canada}

The Canadian government has three major programs to support the development of renewable energy: $:^{231}$

- Renewable Energy and Hybrid Systems Program (which seeks the development and implementation of PV technologies in domestic and international markets where it is economically feasible)

- Renewable Energy Information and Awareness Program

- Renewable Energy Technologies Program (which seeks to develop and commercialize renewable energy technologies, such as active solar, wind power, bioenergy and small hydropower, in conjunction with industry).

The private sector is also establishing programs to support the development of renewable energy. For instance, Ontario Hydro has set up the renewable energy technologies (RET) program, whose first request for proposals was in May $1995 .{ }^{232}$ Projects to be considered include individual wind turbines of Canadian adaptation and small and medium-sized wind farms, biomass generators, anaerobic digestion generators, sewage treatment gas generators, and hybrid technologies. While small power producers have welcomed the program, they are disappointed with the exclusion of small hydropower and landfill gas energy conversion projects, and with the small size of the solicitation. However, the company, like other Canadian utilities, is burdened by overcapacity (as much as 5,000 megawatts of excess capacity in 1995).

\section{Costa Rica}

The administration of President Jose Maria Figueres has signed executive orders and legislative proposals to adopt sustainable development as the guiding vision for the country. As part of a sweeping plan for green economic growth grounded on social justice, Costa Rica has set the goal of producing 98 percent of its electricity from renewable sources by 2000.233

\footnotetext{
${ }^{227}$ A. Kulik, "Energy Recovery Is High Priority for Europeans," World Wastes, Vol. 38, No. 5 (May 1995), pp. 9-12.

${ }^{228}$ R.H. Acker and D.M. Kammen, "The Quiet (Energy) Revolution: Analyzing the Dissemination of Photovoltaic Power Systems in Kenya," Energy Policy, Vol. 24, No. 1 (January 1996), p. 81.

229"The Future of Energy: The Battle for World Power," The Economist, Vol. 337, No. 7935 (October 7, 1995 ), p. 26.

230"Sunshine and Showers," The Economist, Vol. 337, No. 7937 (October 21, 1995), p. 84.

${ }^{231}$ The information in this section was obtained from David McLellan, Office of the Counselor, Economic and Trade Policy, Canadian Embassy, Washington, DC (August 22, 1996).

${ }^{232}$ D. Bright and S. Salaff, "RFP Role Reversal," Independent Energy, Vol. 25, No. 9 (November 1995), pp. 16-19.

${ }^{233} \mathrm{D}$. Tenenbaum, "The Greening of Costa Rica," Technology Review, Vol. 98, No. 7 (October 1995), pp. 42-52.
} 
Table 42. Renewable Energy Resources and Market Potential in Asia and the Pacific and Africa

\begin{tabular}{|c|c|c|c|c|c|c|c|c|}
\hline \multirow[b]{2}{*}{ Country } & \multicolumn{2}{|c|}{$\begin{array}{c}\text { Biomass } \\
\text { (Megawatts) }\end{array}$} & \multicolumn{2}{|c|}{$\begin{array}{l}\text { Geothermal } \\
\text { (Megawatts) }\end{array}$} & \multicolumn{2}{|c|}{$\begin{array}{c}\text { Solar } \\
\text { (Kilowatthours per } \\
\text { Square Meter) }\end{array}$} & \multicolumn{2}{|c|}{$\begin{array}{c}\text { Wind } \\
\text { (Megawatts) }\end{array}$} \\
\hline & $\begin{array}{c}\text { Market } \\
\text { Potential }\end{array}$ & $\begin{array}{c}\text { Resource } \\
\text { Assessment }\end{array}$ & $\begin{array}{l}\text { Market } \\
\text { Potential }\end{array}$ & $\begin{array}{c}\text { Resource } \\
\text { Assessment }\end{array}$ & $\begin{array}{l}\text { Market } \\
\text { Potential }\end{array}$ & $\begin{array}{c}\text { Resource } \\
\text { Assessment }\end{array}$ & $\begin{array}{c}\text { Market } \\
\text { Potential }\end{array}$ & $\begin{array}{c}\text { Resource } \\
\text { Assessment }\end{array}$ \\
\hline \multicolumn{9}{|l|}{ Asia and the Pacific } \\
\hline China ........ & - & a & 600 & 1,800 & d & 4.0 & 1,336 & 253,000 \\
\hline India .. & 3,800 & 17,000 & - & $\begin{array}{l}2,000- \\
10,000\end{array}$ & e & 4.5 & 3,065 & $\begin{array}{l}20,000- \\
80,000\end{array}$ \\
\hline Indonesia ..... & 1,800 & 10,000 & 1,200 & $\begin{array}{l}19,000- \\
42,600\end{array}$ & - & 4.0 & - & 一 \\
\hline Pakistan ... & 300 & - & - & $\begin{array}{l}2,630 \\
4,000\end{array}$ & - & 5.3 & - & - \\
\hline Philippines .... & 9 & $b$ & 1,978 & 70 & - & 3.9 & 一 & - \\
\hline Russia ....... & - & c & 110 & $\begin{array}{l}25,500- \\
58,470\end{array}$ & - & 4.5 & 200 & 一 \\
\hline Subtotal... & 5,909 & 27,000 & 3,886 & - & $\begin{array}{l}100- \\
2,500\end{array}$ & 26.2 & 4,601 & $\begin{array}{l}273,000 \\
33,3000\end{array}$ \\
\hline
\end{tabular}

Africa

South Africa ....

$-$

$-$

$-$

$-$

$f$

6.5

1,960

$a=260$ million tons oil equivalent.

$b=105$ million terawatts-electric annual yield.

$c=60$ million tons oil equivalent.

$d=135$ peak megawatts.

$e=30$ peak megawatts.

$f=150$ peak megawatts through 2010; total, 375 megawatts.

Note: Letters indicate availability of only partial totals or totals in different units. Dashes indicate data not available.

Source: U.S. Export Council for Renewable Energy, Global Impact Analysis Report, submitted to the U.S. Department of Energy, Golden Field Office (August 1996).

The geothermal generation capacity of Costa Rica in 1995 was 55 megawatts. The main geothermal field is the Miravalles Field, where two plants were built in the early 1990s. One is a 50-megawatt single-flash condensing plant, the other a 55-megawatt plant expected to come on line in 1997. Including plants in construction and in the planning stage, capacity by the year 2000 should be about 170 megawatts.

In the area of wind, the New World Power Corporation is participating in a project to build three wind power plants, each with 20 megawatts of capacity. ${ }^{234}$ The power produced displaces fossil-fuel-fired generation and is sold to the Costa Rican Institute of Electricity.
The first plant came on line in May 1996, the second is under construction, and the third is in the planning stage.

\section{Mexico}

As a member of the North American Free Trade Agreement (NAFTA), Mexico is obliged to address its significant environmental problems. To that effect, the World Bank and the North American Development Bank are making available loans and other assistance funds. The second-largest sector of the Mexican environmental market is renewable energy. ${ }^{235}$

\footnotetext{
234"Tucson Electric, New World Power Joint Implementation Projects Chosen," Global Climate Change (January 5, 1996$),$ p. 10.

${ }^{235}$ G. House, “Mexico's House Cleaning Means a Mess of Opportunity,” World Trade, Vol. 98, No. 11 (December 1995$)$, pp. 38-41.
} 
Table 43. Renewable Energy Resources and Market Potential in the Americas

\begin{tabular}{|c|c|c|c|c|c|c|c|c|}
\hline \multirow[b]{2}{*}{ Country } & \multicolumn{2}{|c|}{$\begin{array}{c}\text { Biomass } \\
\text { (Megawatts) }\end{array}$} & \multicolumn{2}{|c|}{$\begin{array}{l}\text { Geothermal } \\
\text { (Megawatts) }\end{array}$} & \multicolumn{2}{|c|}{$\begin{array}{c}\text { Solar } \\
\text { (Kilowatthours per } \\
\text { Square Meter) }\end{array}$} & \multicolumn{2}{|c|}{$\begin{array}{c}\text { Wind } \\
\text { (Megawatts) }\end{array}$} \\
\hline & $\begin{array}{c}\text { Market } \\
\text { Potential }\end{array}$ & $\begin{array}{c}\text { Resource } \\
\text { Assessment }\end{array}$ & $\begin{array}{c}\text { Market } \\
\text { Potential }\end{array}$ & $\begin{array}{c}\text { Resource } \\
\text { Assessment }\end{array}$ & $\begin{array}{c}\text { Market } \\
\text { Potential }\end{array}$ & $\begin{array}{c}\begin{array}{c}\text { Resource } \\
\text { Assessment }\end{array} \\
\end{array}$ & $\begin{array}{c}\text { Market } \\
\text { Potential }\end{array}$ & $\begin{array}{l}\text { Resource } \\
\text { Assessment }\end{array}$ \\
\hline \multicolumn{9}{|l|}{ Central America } \\
\hline Costa Rica . . . . . & a & b & 950 & 2,240 & - & 4.5 & - & $60-3,000$ \\
\hline El Salvador $\ldots .$. & - & - & $165-250$ & 400 & - & 2.0 & - & - \\
\hline Guatemala ...... & - & 500 & 100 & 1,800 & - & 4.5 & - & 60 \\
\hline Honduras ....... & c & $d$ & 一 & 120 & 5.0 & - & - & - \\
\hline Nicaragua.... & 一 & - & - & 2,000 & 一 & 4.5 & - & - \\
\hline Panama ........ & - & - & - & 360 & - & - & - & - \\
\hline Subtotal $\ldots \ldots$ & - & - & $\begin{array}{l}1,165- \\
1,350\end{array}$ & 6,920 & - & - & $180-380$ & $120-3,060$ \\
\hline \multicolumn{9}{|l|}{ North America } \\
\hline Mexico . . . . . . . & - & 1,000 & 960 & $1,200-2,500$ & - & 4.2 & $80-394$ & 5,000 \\
\hline \multicolumn{9}{|l|}{ Caribbean } \\
\hline Barbados ....... & - & 12 & - & - & - & 4.0 & - & - \\
\hline Dominica ....... & - & - & - & 280 & - & - & - & - \\
\hline Dominican Republic & - & $15-45$ & - & - & - & 5.0 & - & - \\
\hline Haiti ........... & - & 一 & - & - & - & 5.0 & 一 & - \\
\hline Jamaica ........ & - & - & 一 & - & - & 5.0 & - & 一 \\
\hline Subtotal ..... & - & $27-57$ & - & 290 & - & $4.0-7.0$ & - & - \\
\hline \multicolumn{9}{|l|}{ South America } \\
\hline Argentina ...... & - & $\theta$ & - & g & 3.8 & 一 & 一 & 500,000 \\
\hline Bolivia ........ & - & - & 50 & - & 4.0 & 一 & - & - \\
\hline Brazil ......... & $\begin{array}{c}3,200 \\
8,800\end{array}$ & - & - & 一 & 3.5 & - & - & 21,700 \\
\hline Chile...$\ldots \ldots$ & - & $f$ & - & h & 1.9 & - & 一 & 25,000 \\
\hline Peru...$\ldots \ldots$ & - & - & 2,000 & - & 4.5 & - & - & - \\
\hline Subtotal $\ldots \ldots$ & $\begin{array}{l}3,200- \\
8,800 \\
\end{array}$ & - & 2,050 & - & 17.7 & - & - & 546,700 \\
\hline
\end{tabular}

$a=17$ to 500 million kilowatthours per year from sugarcane.

$b=400$ to 500 million kilowatthours per year from sugarcane.

$c=54$ million kilowatthours per year from sawmill.

$d=\mathbf{3 0}$ million kilowatthours per year from sawmill.

$e=50$ megawatts at Copahue field, othenwise unknown.

$f=$ Large but inaccessible.

$g=186$ peak megawatts.

$h=50$ peak megawatts.

Note: Letters indicate availability of only partial totals or totals in different units. Dashes indicate data not available.

Source: U.S. Export Council for Renewable Energy, Global Impact Analysis Report, submitted to the U.S. Department of Energy, Golden Field Office (August 1996). 
At present, Mexico has installed geothermal energy capacity of 753 megawatts at three fields: Cerro Prieto (620 megawatts), Los Azufres (98 megawatts), and Los Humeros (35 megawatts). ${ }^{236}$ There are plans to add four 20-megawatt units at Cerro Prieto in 1997 and two 64-megawatt experimental plants after that. At Los Humeros, a 3-megawatt experimental unit was added in 1995, and 3 megawatts more are planed for the future. At La Primavera, a 70-megawatt potential has been identified and may be developed in the future. Finally, a 40-megawatt addition is planned at Los Azufres. Thus, by the year 2000, Mexico plans to have about 960 megawatts on line. The Comision Federal de Electricidad continues to devote substantial professional resources to geothermal activities, including about 200 man-years of scientific activity per year (as of 1994). In addition, both private industry and universities have expended significant resources on geothermal energy efforts.

In terms of solar and PV, an ice-making system with a parabolic trough solar collector was installed in Maruata, Michoacan, in 1992. Also, one of several rural PV electrification pilot projects is producing more than 1,600 kilowatthours per square meter per year. ${ }^{237}$

\section{Asia and the Pacific}

Table 42 shows an assessment, by a consortium of nonprofit industry trade associations, of renewable energy resources and market potential in the region. The following sections focus on two representative countries: Indonesia and the Philippines.

\section{Indonesia}

The government of Indonesia has a goal of 2,000 megawatts of installed geothermal energy capacity by 2000 an additional 1,691 megawatts over $1995 .{ }^{238}$ The additional capacity will come in part from 740 megawatts in Java, 20 megawatts in Sulawesi, and 10 megawatts of mini-plant (i.e., 35 to 1,000 kilowatts) installations for rural, off-grid electrification. Another 4,000 megawatts are planned to be on line by 2020, which may make Indonesia the largest geothermal energy producer in the world. ${ }^{239}$
Indonesia recently passed two regulations that affect the geothermal industry. The first allows the stateowned oil company, Pertamina, to sell electricity to the state power company, PLN, and to other agencies. The other regulatory change allows for steam field development and power plant construction by private industry and a decrease in taxes from 46 percent to 34 percent. Most of the projected development will be built by private industry, working under the terms of joint operation contracts signed with Pertamina. Financing for a number of these projects will come from the World Bank.

Table 44 shows Indonesia's geothermal energy potential. The total potential geothermal resources amount to 16,000 megawatts. A host of foreign companies have participated with Pertamina in the development of geothermal energy resources, including Dutch, French, and U.S. companies. Examples of the latter include Unocal, Chevron, Texaco, Caithness Resources, and California Energy International.

\section{The Philippines}

The Philippines is now the world's second-largest producer of geothermal electricity, after the United States. In 1994, the Philippines had an installed capacity of 1,191 megawatts. ${ }^{240}$ The fields now in production and their gross outputs are Mak Ban (426 megawatts), Tiwi (330 megawatts), Tongonan (112.5 megawatts), Palimpinon (193 megawatts), and Bac Man (130 megawatts). An additional 754 megawatts of proven reserves have been identified at nine other sites, and 1,250 to 2,630 megawatts of potential capacity is available at 19 other sites. The total installed capacity by 1998 is estimated at 1,945 megawatts. The development of geothermal power in the Philippines has been difficult at times, but the Filipinos have been successful and have contributed significant technical improvements to the field. Private industry has been active in geothermal development through the government's use of buildoperafe-transfer and build-transfer-operate contracts. The ultimate potential for geothermal power generation is estimated at 3,000 to 4,000 megawatts.

\footnotetext{
${ }^{236}$ International Geothermal Association, "Installed Geothermal Electricity Generation Capacity by Country and Year," web site www.demon.co.uk/geosci/igahome.html (August 28, 1996).

${ }^{237} \mathrm{P}$. Gipe, "Southern Stirrings."

${ }^{238}$ International Geothermal Association, "Installed Geothermal Electricity Generation Capacity by Country and Year."

239"Geothermal Energy in Indonesia," East Asian Executive Reports (May 15, 1995), pp. 12-16.

${ }^{240}$ International Geothermal Association, "Installed Geothermal Electricity Generation Capacity by Country and Year," web site www.demon.co.uk/geosci/igahome.html (August 28, 1996).
} 
Table 44. Geothermal Energy Capacity in Indonesia

(Megawatts)

\begin{tabular}{|c|c|c|c|c|}
\hline \multirow[b]{2}{*}{ Area } & \multicolumn{4}{|c|}{ Geothermal Energy Capacity } \\
\hline & Installed & Proven & Probable & Potential Resources \\
\hline \multicolumn{5}{|l|}{ Java and Ball } \\
\hline Kamojanj ........... & 142.0 & 210 & 300 & 462 \\
\hline Dieng . . . . . . . . . . . & 2.2 & 285 & 575 & 1,430 \\
\hline 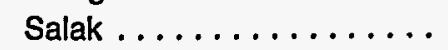 & 55.0 & 280 & 370 & 600 \\
\hline Darajat ............. & - & 120 & 250 & 420 \\
\hline Wayang Windu . . . . . . . . & - & - & 260 & 420 \\
\hline Patuha .............. & - & - & 400 & 685 \\
\hline Telaga Bodas . . . . . . . . . . & - & - & 200 & 300 \\
\hline Karaha .............. & - & - & 200 & 250 \\
\hline Wills $\ldots \ldots \ldots \ldots \ldots$. & - & - & 100 & 170 \\
\hline Bali $\ldots \ldots \ldots \ldots \ldots$ & - & - & 215 & 325 \\
\hline Others $\ldots \ldots \ldots \ldots \ldots$ & - & - & 2,050 & 3,400 \\
\hline Subtotal ........... & 199.2 & 895 & 4,920 & 8,100 \\
\hline \multicolumn{5}{|l|}{ Sumatra } \\
\hline Sibajak............. & - & - & 140 & 240 \\
\hline Sarulla ............... & - & - & 280 & 380 \\
\hline Sibualbuali ............. & - & - & 600 & 750 \\
\hline Kerinci .............. & - & - & 75 & 115 \\
\hline Others $\ldots \ldots \ldots \ldots \ldots$ & - & - & 2,500 & 3,400 \\
\hline Subtotal $\ldots \ldots \ldots \ldots$ & - & - & 3,595 & 4,885 \\
\hline \multicolumn{5}{|l|}{ Sulawesi } \\
\hline Lahendong....$\ldots \ldots$ & 205.0 & 65 & 175 & 300 \\
\hline Tompaso ............. & - & - & 230 & 400 \\
\hline Kotamobagu .......... & - & - & 200 & 300 \\
\hline Others $\ldots \ldots \ldots \ldots \ldots$ & - & - & 350 & 500 \\
\hline Subtotal $\ldots \ldots \ldots \ldots$ & 205.0 & 65 & 955 & 1,500 \\
\hline Other Areas Subtotal $\ldots$ & - & - & 1,050 & 1,550 \\
\hline Country Total $\ldots \ldots \ldots$ & 404.2 & 960 & 10,520 & 16,035 \\
\hline
\end{tabular}

Note: A probable resource is one that has a greater than 50 percent chance of possessing geothermal energy capacity. A potential resource is defined as having a less than 50 percent chance of possessing geothermal energy capacity.

Source: "Geothermal Energy in Indonesia," East Asian Executive Reports (May 15, 1995), pp. 12-16.

\section{Selected Countries in Europe}

\section{Denmark}

Present-day wind power technology owes much to the early efforts of firms of the United States and Denmark in the 1970s and 1980s. ${ }^{241}$ Although both sets of companies started out around the same time, with similar knowledge and technology, and aided by government incentives, Danish firms are generally credited with the superior performance of their wind turbines. This led to the capture of significant market share in the U.S. market. Between 1982 and 1986, the Danish market share of the rapidly expanding California wind farm market rose from 0 percent to 68 percent. At the end of the decade, Danish firms accounted for 45 percent of installed turbines. By 1993, the Danish cumulative share of the world market was 53 percent, while the U.S. share was roughly 25 percent, mostly concentrated in the United States. The annual worldwide market share of Danish firms rose from 38 percent in 1993 to 44 percent in 1994, giving them a preeminent position in the world market.

${ }^{241}$ P. Karnoe, "Competence as Process and the Social Embeddedness of Competence Building," Academy of Management Journal (1995), pp. $427-431$. 
Recent wind energy projects in Denmark include the Velling Maersk-Taendpibe plant, in Jutland Peninsula, which consists of 100 turbines, and a 23.4-megawatt plant operating at Rejfvy Hede since 1995. Denmark also has about 60 district heating biomass conversion plants. The fuels of choice for these plants are straw and wood chips.

\section{Finland}

Finland's geography has endowed it with abundant wind energy resources. There are a number of projects designed to take advantage of these resources. The most important one is the Kopparnäs Wind Power Park, which consists of three turbines installed beginning in 1986. The latest, built in 1995, is a 50-kilowatt hydrotronic turbine. ${ }^{242}$ This turbine uses a novel power transmission technology, using hydraulics to transmit to a generator located on the ground, which generates electricity directly to the high-voltage network. Also at Kopparnäs, a PV plant was commissioned in 1989 by IVO, a Finish utility.

\section{International Efforts in Support of Renewable Energy}

\section{The World Bank}

As of mid-1996, the Word Bank and its Global Environmental Facility had a combined 41 projects in several stages of development, from appraisal to ongoing (Table 45). The Bank's renewable energy projects in the pipeline for fiscal years 1997 and 1998 amount to a total Bank component (share) cost of $\$ 468$ million. ${ }^{243}$

The World Bank created the Solar Initiative in 1994 to coordinate its projects in the area of renewable energy. The Solar Initiative is not a distinct entity within the World Bank but rather a part-time reallocation of existing human resources. ${ }^{244}$

\section{The Inter-American Development Bank}

The Inter-American Development Bank (IDB) has also been active in supporting renewable energy, although the level of lending has not always satisfied donors and advocates. Reasons for this dissatisfaction include the relative cost-effectiveness of proposed projects, institutional and regulatory frameworks, the absence of private sector participation, current level of development of the technology, and other project-specific reasons. ${ }^{245}$ The IDB had the following renewable energy project in FY 1996:

- Tilaran Wind Power Plant, Costa Rica: construction and operation of a 20-megawatt wind-power electric plant near Tejona, in Guanacaste Province. The plant will be owned by Plantas Eólicas and its production sold to Costa Rica's national grid under a power purchase agreement with the Instituto Costarricence de Electricidad (ICE). The plant will consist of 55 advanced-design wind generators, capable of producing approximately 92 gigawatthours of energy per year. The plant is estimated to reduce or replace $\mathrm{CO}_{2}$ emissions from thermal power plants by more than 75,000 metric tons each year. The IDB has provided a loan of up to $\$ 11.5$ million.

\section{U.S. Agency for International Development}

USAID has renewable energy programs managed incountry by five field offices-Mexico, Dominican Republic, India, Indonesia, and the Philippines-and two global programs managed by the Office of Energy, Environment, and Technology in the Center for the Environment at USAID in Washington, DC. The two programs managed out of Washington are Renewable Energy Applications and Training (REAT) and Biomass Energy Systems and Technology (BEST). The two latter programs are summarized below and in Table $46 .{ }^{246}$

\section{Renewable Energy Applications and Training}

The REAT project was created in 1985 to promote and assist in the application of economically and environmentally sustainable renewable energy technologies in USAID-assisted countries. Worldwide project activities include renewable energy project identification, design, preparation for financing, and development; education and training; economic and technical evaluation; trademission support; and provision of educational and promotional information on technologies, applications, and U.S. vendors in the area of sustainable energy.

\footnotetext{
${ }^{242}$ IVO Group, web site www.ivogroup.com (August 6, 1996).

${ }^{243}$ A. Young and E. Terrado, World Bank Pipeline Renewable Energy Projects (FY97-98), Solar Initiative, The World Bank Group (August 22 and November 18, 1996).

${ }^{244}$ Personal communication between Gabriel Sanchez, Science Applications International Corporation, and Ernie Terrado, Principal Energy Planner, Industry and Energy Department, The World Bank (October 10, 1996).

${ }^{245}$ Inter-American Development Bank, Environment Committee, 1995 Annual Report on the Environment and Natural Resources (Washington, DC, 1996).

${ }^{246}$ Unless otherwise noted, the source for USAID renewable energy information is personal communication between Gabriel Sanchez (Science Applications International Corporation) and Rebecca Slone (U.S. Agency for International Development, Office of Energy, Environment, and Technology, Center for Environment), October 16 and 17, 1996.
} 
Table 45. World Bank Renewable Energy Projects, Approved and in the Pipeline, 1996

\begin{tabular}{|c|c|c|c|c|}
\hline Country & Project Name. & Status & Technologies & $\begin{array}{c}\text { Free- } \\
\text { Standing } \\
\text { Status }\end{array}$ \\
\hline \multicolumn{5}{|l|}{ Africa } \\
\hline Benin .......... & Renewable Energy & Pipeline & Unspecified & No \\
\hline Mauritius $\ldots . \ldots$ & $\begin{array}{l}\text { Sugar Bio-Energy Technology } \\
\text { Project }\end{array}$ & Ongoing & Cane/coal cogeneration & Yes \\
\hline Tunisia ......... & Tunisia Solar Water Heating & Ongoing & Solar hot water & Yes \\
\hline Cameroon ...... & Cameroon Energy Project & Pre-IEPS & Unspecified, PV assumed & No \\
\hline Cape Verde ...... & Cape Verde Power Project & Pre-IEPS & Wind, PV & No \\
\hline Cape Verde ...... & Energy $/$ Water Project & Pipeline & Unspecified & No \\
\hline Chad .... & Household Energy \& T.A. & Appraisal & Unspecified, PV assumed & No \\
\hline Ethiopia ........ & Energy Sector & Pipeline & Unspecified & No \\
\hline Mall ........... & NA & Pre-IEPS & Solar PV & Yes \\
\hline Morocco .. & NA & Concept & Unspecified, PV assumed & Yes \\
\hline Tunisia .... & Renewable Energy Strategy Study & Concept & Solar PV & Yes \\
\hline Zambia & Zambia Power Rehabilitation Project & IEPS & Unspecified, PV assumed & No \\
\hline Zimbabwe $\ldots \ldots$ & Zimbabwe Energy Project & IEPS & Unspecified, PV assumed & No \\
\hline Niger..$\ldots \ldots \ldots$ & Niger Energy Project & Ongoing & NA & No \\
\hline Djibouti & Djibouti Geothermal II & Ongoing & Geothermal & No \\
\hline Kenya...$\ldots \ldots$ & Kenya Geothermal Development & Ongoing & Geothermal & Yes \\
\hline \multicolumn{5}{|l|}{ East Asia and Pacific } \\
\hline Indonesia . & Second Rural Electrification Project & Approved & Mini-hydro, mini-geothermal & No \\
\hline Indonesia ....... & Solar Home Systems & Pipeline & Solar PV & Yes \\
\hline China .......... & China FY 98 GEF Project & Appraisal & $\begin{array}{l}\text { Unspecified: PV, wind, biomass, } \\
\text { hydro }\end{array}$ & No \\
\hline Philippines ...... & Leyle-Cebu Geothermal Project & Ongoing & Geothermal power & Yes \\
\hline Philippines ... & Leyle-Luzon Geothermal Project & Ongoing & Geothermal power & Yes \\
\hline Indonesia .... & $\begin{array}{l}\text { Indonesia Renewable Energy } \\
\text { Development }\end{array}$ & FEPS & PV, biomass, wind, mini-geothermal & Yes \\
\hline Indonesia. & $\begin{array}{l}\text { Hybrid Renewable Energy for } \\
\text { Remote Applications }\end{array}$ & Concept & PV, wind, diesel hybrids & Yes \\
\hline Philippines ...... & Bacon Manito Geothermal & Ongoing & Geothermal & Yes \\
\hline Philippines ...... & Philippines Energy Sector Loan & Ongoing & Geothermal & Yes \\
\hline \multicolumn{5}{|l|}{ South Asia } \\
\hline India $\ldots$. & $\begin{array}{l}\text { Indian Renewable Energy } \\
\text { Resources Development }\end{array}$ & Ongoing & PV, wind, micro-hydro & No \\
\hline Pakistan ........ & Pakistan Waste-to-Energy & Pre-appraisal & Landfill methane power & Yes \\
\hline India $\ldots . . . \ldots$. & India Solar Thermal Power & FEPS & $\begin{array}{l}\text { High-temperature solar parabolic } \\
\text { trough }\end{array}$ & Yes \\
\hline Sri Lanka ......... & Energy Services Delivery & FEPS & PV, wind, mini-hydro & Yes \\
\hline
\end{tabular}


Table 45. World Bank Renewable Energy Projects, Approved and in the Pipeline, 1996 (Continued)

\begin{tabular}{|c|c|c|c|c|}
\hline Country & Project Name & Status & Technologies & $\begin{array}{l}\text { Free- } \\
\text { Standing } \\
\text { Status }\end{array}$ \\
\hline \multicolumn{5}{|l|}{ Europe } \\
\hline Lithuania . . . . . . & Lithuania Geothermal Project & Appraisal & Geothermal district heating & No \\
\hline Poland ......... & $\begin{array}{l}\text { Geothermal \& Environmental } \\
\text { Project }\end{array}$ & Appraisal & Biomass & Yes \\
\hline Hungary ......... & Hungary Biomass Project & IEPS & Geothermal district heating & Yes \\
\hline Poland . . . . . . . . & Poland Geothermal Project II & IEPS & Geothermal district heating & No \\
\hline Slovak Republic . & Slovak Republic Geothermal Project & Appraisal & Geothermal district heating & Yes \\
\hline \multicolumn{5}{|l|}{ Latin America } \\
\hline Bolivia & Rural Electrification Project & Pipeline & Unspecified & No \\
\hline Costa Rica & Electric Power Development Loan & Approved & Wind & No \\
\hline Brazil & Biomass Pilot Power Project & Appraisal & $\mathrm{BIG/GT}$ & No \\
\hline Peru $\ldots$. & $\begin{array}{l}\text { FY } 97 \text { WB/IDB Rural Electrification } \\
\text { Project }\end{array}$ & IEPS & Unspecified & Yes \\
\hline Argentina . . . . . . & Power Sector Policy Reform & Pre-IEPS & Unspecified; PV and small wind & No \\
\hline Brazil . . . . . & Energy Efficiency and Conservation & Approved & Cane-cogeneration & No \\
\hline Guatemala ....... & Panteleon Sugar Mill Project & Ongoing & PV, wind, micro-hydro & No \\
\hline
\end{tabular}

FEPS = final executive project summary; FY = fiscal year; GEF = Global Environmental Facility (part of the World Bank Group); IDB = Inter-American Development Bank; IEPS = initial executive project summary; $N A=$ not available; $P V=$ photovoltaic; $W B=$ World Bank.

Notes: "Concept" means the project is being informally discussed only. "Pre-IEPS" is the phase before IEPS when the project is under discussion only. "Appraisal" indicates the formal field mission to the project area is addressing financial, legal, technical, and economic analysis questions associated with the project. "Pipeline" means an approved project is formally put in the lending program at the WB for the purpose of timing disbursements. "Ongoing" indicates the project has been approved, the loan is effective, and money is disbursed. In the Free-Standing Status column, "yes" indicates the entire project is in the renewable energy area; "no" indicates renewable energy is just a component of a larger, diversified project.

Source: A. Young and E. Terrado, World Bank Pipeline Renewable Energy Projects (FY97-98), Solar Initiative, The World Bank Group (August 22 and November 18, 1996).

REAT promotes the use of cost-effective, commercially viable renewable energy technologies and applications utilizing solar, wind, biomass, geothermal, and small hydro resources, emphasizing private-sector participation. REAT assists in the identification of viable commercial projects and in sharing the cost of preinvestment studies that can leverage project financing and implementation. REAT also works with host country government institution, USAID missions, and private sector interests to design, develop, and evaluate projects and programs that will lead to the export of U.S. renewable energy products and services.

Project accomplishments include the following:

- Establishment of Renewable Energy Project Support Offices (REPSOs) staffed by local and U.S. personnel in Central America, Indonesia, the Philippines,
India, and Brazil in cooperation with the BEST project.

- Support for the International Fund for Renewable Energy and Efficiency; which has provided funds for 12 projects in 8 countries.

- Funding for the Environmental Enterprises Assistance Fund, a nonprofit investment company that makes loans and investments in environmentally preferred businesses and projects.

\section{Biomass Energy Systems and Technology}

The BEST project was created in 1989 to identify and reduce the technological, economic, financial, and institutional risks of investments in biomass power production in USAID-assisted countries. Project activities take place simultaneously in Latin America and 
Table 46. USAID Renewable Energy Host Country Projects Under BEST and REAT as of December 31, 1995

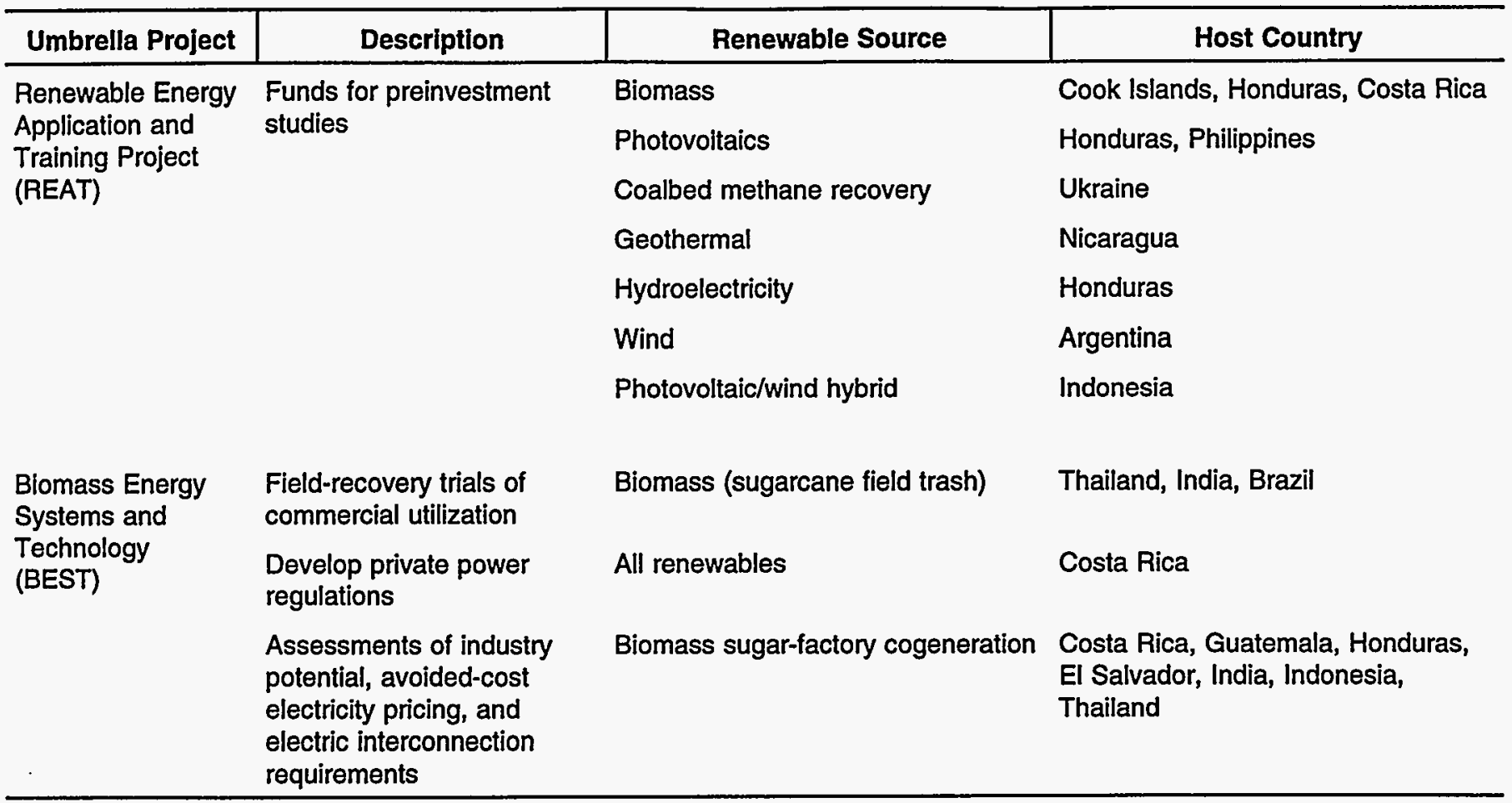

Source: R. Slone, Energy, Environment and Technology, Center for Environment, U.S. Agency for International Development (Washington, DC, October 1996).

Asia and include industry resource assessments, feasibility studies, technical assistance, workshops, technical exchanges, and information dissemination.

The project focuses primarily on the generation of electricity from agricultural residues, such as crop wastes from sugar and rice and wood-wastes. It promotes the use of commercially proven technologies and systems adapted to the conditions in developing countries.

Project accomplishments include the following:

- Extensive work to stimulate the development of expanded sugar-industry power generattion in Latin America and Asia.

- Assessments of industry potential, avoided-cost electricity pricing, and electric system interconnection requirements in each country. These assessments have helped to create a framework for expanded sugar-factory cogeneration in Costa Rica, Guatemala, Honduras, El Salvador, India, Indonesia, and Thailand.

- Work to bring sugarcane field trash, a promising new fuel, to commercial utilization, by conducting field-recovery trials in Thailand, India, and Brazil and developing data collection protocols for recovery and boiler tests.
- Assistance to site-specific private sector project proposals by sharing the costs of pre-investment studies.

- Help in establishing Renewable Energy Project Support Offices staffed by local personnel in Central America, Indonesia, the Philippines, India, and Brazil (in cooperation with the REAT project). As of mid-1995, these offices had made grants for preinvestment studies for three sugar mills and one wood plantation and had also helped develop private power regulations that led to the development of plans for the addition of more than 250 megawatts of electric capacity from renewable sources.

- Launch of the International Cane Energy Network to institutionalize cooperation among private sugarindustry research and development organizations.

- Help in accelerating the development and commercialization of biomass gasifier/advanced gas turbine technology, which is expected to achieve twice the energy conversion efficiency of conventional power production systems.

- Development of replicable, peer review methods and procedures for measuring carbon sequestration over time in forestry plantations. 


\section{Other International Organizations}

\section{Center for the Analysis and Dissemination of Demonstrated Energy Technologies}

The International Energy Agency (IEA) created the Center for the Analysis and Dissemination of Demonstrated Energy Technologies (CADDET) to disseminate information on demonstrated energy efficiency and renewable energy technologies and to enhance the exchange of information among member countries on new energy saving and renewable energy technologies that have been demonstrated in applications in all enduse sectors. ${ }^{247}$ CADDET will only be in effect through 1998. Its 1996 activities included the promotion of CADDET products, publication of brochures and newsletters, and workshops.

\section{Asia-Pacific Economic Cooperation}

The Asia-Pacific Economic Cooperation (APEC) was created to promote the economic and social well-being of the Asia-Pacific region by cooperating in several economic areas. ${ }^{248}$ One of the areas is renewable energy technology cooperation, where APEC has an Energy Efficiency and Renewable Energy Program.

\section{The European Business Council for a Sustainable Energy Future}

The European Business Council for a Sustainable Energy Future promotes technologies that fight global warming. No additional information is available at this time.

\section{U.S. Government Efforts in Support of Renewable Energy}

In followup to the Hemisphere Energy Symposium, which took place October 29-31, 1995, in Washington, $D C$, as preparation for the Summit on Sustainable Development, the U.S. Department of Energy participated in the Hemispheric Energy Ministerial Meeting, July 31August 2, 1996, in Santa Cruz de la Sierra, Bolivia. This meeting was attended by energy ministers from the western hemisphere, the Hemispheric Energy Steering Committee, other government representatives, multilateral development banks, financial institutions, the private sector, and nongovernmental organizations.
The Hemispheric Energy Ministerial Meeting had the following goals: increasing investment in the energy sector, promoting clean energy technologies, furthering regulatory cooperation, promoting hemispheric collaboration to support economic and environmental sustainability in the oil sector, presenting new opportunities for the use of natural gas, supporting energy efficiency, developing rural electrification strategies in the hemisphere, and future projects to be developed on a regional level in the hemisphere. The meeting concluded with a declaration of principles on sustainable energy development, establishment of technical assistance programs, and cooperation in implementing energy projects in the hemisphere.

\section{Committee on Renewable Energy Commerce and Trade}

The Committee on Renewable Energy Commerce and Trade (CORECT) is a 14-member interagency working group of the Federal Government that began as a response to increasing competition from governmentaided European and Asian industries. ${ }^{249}$ Its objectives are to forge an effective partnership between the U.S. private sector and the Federal Government to mobilize the resources of the CORECT member agencies and assist the renewable energy industry to increase international market share.

The committee's activities include cofunding and cosponsoring of trade missions; and sponsoring the development of the FINESSE (Financing Energy Service for Small Scale Energy Users) program to aid in the bundling of smaller renewable energy loans into larger loan packages for consideration by development banks and commercial lending institutions. This led to the formation of the Asia Alternative Energy (ASTAE) unit, part of the World Bank Group, which has approved a $\$ 450$ million renewable resources development project for India and is currently reviewing significant renewable energy loan packages for a number of other Asian nations.

\section{Memorandum of Cooperation with Russian Ministry of Fuels and Energy}

A memorandum of cooperation signed in October 1993 by the U.S. Department of Energy (DOE) and Russia's Ministry of Fuels and Energy has as its objectives to identify viable, cost-effective energy efficiency and

${ }^{247}$ U.S. Department of Energy, Office of Energy Outreach, Program Briefing (February 21, 1996).

${ }^{248}$ U.S. Department of Energy, Office of Energy Outreach, Program Briefing (February 21, 1996).

${ }^{249}$ U.S. Department of Energy, Office of Energy Outreach, Program Briefing (February 21, 1996). 
renewable energy projects; to identify project financing; and to provide training to Russians. ${ }^{250}$ The agreement's activities include workshops, business plan training, and technical assistance. One project, a geothermal plant in Kamchatcka, has begun a first phase and has attracted interest for later phases. Progress has also been made on three priority renewable projects: a $\mathrm{PV}$ and wind energy system demonstration project in Fili Park, Moscow; wind turbine pilot projects in the northern Russian territories, which have been highly effective; and an agreement to build a 1-megawatt electric power plant using wood processing wastes.

\section{Other U.S. Department of Energy Programs and Participation}

DOE participates in Asia-Pacific Economic Cooperation (APEC) with the following objectives: to disseminate information on U.S. demonstrated energy efficiency and renewable energy technologies to decisionmakers in APEC nations; to link U.S. producers with new export markets; to provide an avenue for identifying specific export opportunities; and to promote private sector interaction between member countries in developing the infrastructure to support an expansion in the delivery of energy efficiency and renewable energy products and services nationwide. ${ }^{251}$ The program's activities include technical support, hosting workshops, technology analysis, business development, and resource assessments.

The U.S. Export Council for Renewable Energy (US/ ECRE) is a consortium of nonprofit industry trade associations funded in part by DOE. This organization supports the export activities of the domestic renewable energy and energy efficiency industries.

${ }^{250}$ U.S. Department of Energy, Office of Energy Outreach, Program Briefing (February 21, 1996).

${ }^{251}$ U.S. Department of Energy, Office of Energy Outreach, Program Briefing (February 21, 1996). 
Appendices 
ma 


\section{Appendix A \\ EIA Renewable Energy Data Sources}

The Energy Information Administration (EIA) develops renewable energy information from a wide variety of sources, cutting across different parts of the organization. This appendix provides a list of all sources which the EIA uses to obtain renewable energy information. While most data come from EIA data collection forms, some are derived from secondary sources. For EIA data collections, additional information is available in the EIA publication Directory of Energy Data Collection Forms, DOE/EIA-0249(94), December 1994.

\section{EIA-63A/B, "Annual Solar Thermal Collector Manufacturers Survey" and "Annual Photovoltaic Module/Cell Manufacturers Survey"}

Energy Sources: Solar energy.

Energy Functions: Disposition.

Frequency of Collection: Annually.

Respondent Categories: Photovoltaic module/cell manufacturers and/or importers; solar thermal collector manufacturers and/or importers.

Description: Forms ELA-63A/B are designed to gather for publication data on shipments of solar thermal collectors and photovoltaic modules. Data are collected by end use and market sector. Collector types include low-temperature, medium-temperature air, medium- temperature liquid, thermosiphon, flat plate, concentrator, integral collector storage, and evacuated tube and concentrators. Respondents are manufacturers, importers, and exporters of solar thermal collectors and photovoltaic modules. These forms were formerly known as CE-63A/B.

\section{EIA-457A/H, "Residential Energy Consumption Survey"}

Energy Sources: Coal and coal products; electricity; natural gas; petroleum and petroleum products; wood.

Energy Functions: Consumption costs and/or prices. Frequency of Collection: Triennially.

Respondent Categories: Electric utilities; natural gas distributors (including importers/exporters); petroleum and petroleum product distributors; institutions (nonprofit); individuals/households.
Reporting Requirement: Voluntary and mandatory. Description: Forms ELA-457A through G are used to collect comprehensive national and regional data on both the consumption of and expenditures for energy in the residential sector of the economy. Data are used for analyzing and forecasting residential energy consumption. Housing, appliance, and demographic characteristics data are collected via personal interviews with households, and consumption and expenditure billing data are collected from the energy suppliers. End-use intensities are produced for space heating, water heating, air conditioning, refrigerators, and appliances. Rental agents are contacted by telephone to check on fuels used in rented apartments. Surveys were conducted in 1978, 1979, 1980, 1981, 1982, 1984, 1987, 1990, and 1993. Form EIA- $457 \mathrm{H}$ is used to collect detailed lighting usage information for a subsample.

\section{EIA-846(A,B,C), "Manufacturing Energy Consumption Survey"}

Energy Sources: Coal and coal products; electricity; natural gas; petroleum and petroleum products; wood.

Energy Functions: Consumption; disposition; financial; and/or management; production; research and development; other energy functions.

Frequency of Collection: Triennially.

Respondent Categories: Manufacturing.

Reporting Requirement: Mandatory.

Description: Forms EIA-846A through D are used to collect information on energy consumption, energy usage patterns, and fuel-switching capabilities of the manufacturing sector of the U.S. economy. The information from this survey is used to publish aggregate statistics on the consumption of energy for fuel and nonfuel purposes; fuel-switching capabilities; and certain energy-related issues; such as energy prices, on-site electricity generation, and purchases of electricity from nonutilities. Since 1991, the survey has also collected information on end users of energy, participation in energy management programs, and penetration of new technology. Respondents are a sample of manufacturing establishments in Standard Industrial Classification categories 20 through 39. 


\section{EIA-860, "Annual Electric Generator Report"}

Energy Sources: Electricity.

Energy Functions: Financial and/or management; production.

Frequency of Collection: Annually.

Respondent Categories: Electric utilities.

Reporting Requirement: Mandatory.

Description: Form EIA-860 is used to collect data on the status of electric generating plants and associated equipment in operation and those scheduled to be in operation in the United States within 10 years of filing of the report. These data are used to maintain and update EIA's electric power plant frame data base. Data are collected on power plant sites, and the design data of electric generators. Respondents include each electric utility that operates, or plans to operate, a power plant in the United States within 10 years of the report.

\section{EIA-861, "Annual Electric Utility Report"}

Energy Sources: Electricity.

Energy Functions: Disposition; financial and/or management; production.

Frequency of Collection: Annually.

Respondent Categories: Electric utilities.

Reporting Requirement: Mandatory.

Description: Form EIA-861 is a mandatory collection of data, filed annually by each electric utility in the United States, its territories, and Puerto Rico. The survey collects data on generation, wholesale purchases, and sales and revenue by class of consumer and State. These data are used to maintain and update the EIA's electric utility frame data base. This data base provides information to answer questions from the Executive Branch, Congress, other public agencies, and the general public. Respondents include each electric utility that is a corporation, person, agency, authority, or other legal entity or instrumentality that owns or operates facilities within the United States, its territories, or Puerto Rico for the generation, transmission, distribution, or sale of electric energy primarily for use by the public.

\section{EIA-867, "Annual Nonutility Power Producer Report"}

Energy Sources: Electricity.

Energy Functions: Production.

Frequency of Collection: Annually.

Respondent Categories: Nonutility power producers.

Reporting Requirement: Mandatory.

Description: Form EIA-867 is used to collect data annually from nonutility power producers who own or plan on installing electric generation equipment with a total capacity of one megawatt or more at an existing or proposed site. Electricity generation, installed capacity, and energy consumption data are collected. These data will be used to augment existing electric utility data and for electric power forecasts and analyses.

\section{EIA-871A/F, "Commercial Buildings Energy Consumption Survey"}

Energy Sources: Electricity; natural gas; natural gas products; petroleum and petroleum products; wood; other energy sources.

Energy Functions: Consumption; costs and/or prices. Frequency of Collection: Triennially.

Respondent Categories: Commercial buildings; electric utilities; natural gas distributors (including importers/exporters); petroleum and petroleum product distributors; other (industry); Federal government institutions (nonprofit).

Reporting Requirement: Voluntary and mandatory. Description: Forms EIA-871A through $\mathrm{F}$ are used to collect information for the Commercial Buildings Energy Consumption Survey (CBECS). The survey provides comprehensive national and regional information on the consumption of, and expenditures for, energy in the commercial sector of the economy. Data are used in EIA models and published in statistical and analytical reports. Physical characteristics information for commercial buildings is collected by personal interviews with building owners and managers using Form EIA-871A. Billing and consumption data for the buildings are collected by mail from individual energy suppliers by using Forms EIA-871C through F (depending upon the energy source). Supplemental information on construction improvements, maintenance, and repairs is collected for the Bureau of the Census by using Form EIA-871G. This survey was renamed the CBECS in 1989. Previously it was conducted under the name of Nonresidential Buildings Energy Consumption Survey. 


\section{Appendix B Renewable Data Limitations}

This appendix provides information about the quality of renewable energy consumption data presented in Section I of this report. Information pertinent to renewable energy source data quality, in general, is presented, followed by fuel-specific information.

Obtaining complete information on renewable energy projects poses special challenges due to their nature. One challenge is the dispersed nature of many renewable energy forms, such as a photovoltaic (PV) system for generating electricity that may operate in a "standalone" fashion in a remote location. If the facility is not connected to an electricity grid, there is no Federal regulatory requirement to report its operating information. Tracking down hundreds or thousands of such facilities, each with a small power output, can be extremely challenging.

Another challenge involves tracking renewable energy supplies. Conventional energy supplies, such as petroleum, are easily tracked because the distribution networks (usually pipelines) are limited and well-defined. This permits one to make reasonable assumptions about fuel consumption, assuming stocks can be reasonably estimated. ${ }^{252}$ The same cannot be said for many renewable energy supplies. Often, a large number of energy consumers must be surveyed in order to make reasonable inferences about renewable energy consumption. Wood, for example, is gathered by tens of thousands of entities for fuel uses not reportable for regulatory purposes. Thus, obtaining accurate data on wood energy consumption would entail conducting large consumption surveys.

Finally, some renewable energy sources are byproducts (such as pulping liquor) of non-energy processes. To track such uses, information must be solicited from respondents not generally considered to be in the energy supply chain.

\section{Electricity 253}

As noted in Chapter 1, 66 percent of renewable energy consumption measured by EIA is used to produce electric power. It is therefore important to examine the coverage quality of EIA renewable electricity data. EIA renewable electricity generation is derived from two principal sources: Form EIA-759, "Monthly Power Plant Report," and Form EIA-867, "Annual Nonutility Power Producer Report." Form EIA-759 is sent to all utilities, while the EIA- 867 is required of all other facilities exceeding 1 megawatt capacity. (This includes facilities which meet Federal Energy Regulatory Commission [FERC] standards as a "qualifying facility" $[\mathrm{QF}]$, as well as independent power producers [IPPs]). Therefore, offgrid electric applications are not captured here (although they may be covered in EIA's Manufacturing Energy Consumption Survey ${ }^{254}$ ).

Because electric utilities are easily identified, seldom change business status, and have mandatory regulatory reporting requirements, complete coverage of utilitygenerated electricity is virtually assured. In contrast, nonutilities (i.e., QFs and IPPs) are required only to file regulatory reports at the time of their intention to become a grid electricity-producing facility. Over time, QF ownerships and locations change frequently. These factors, combined with the large number of QF applications, make tracking these facilities difficult. Accordingly, EIA has developed a threshold below which nonutility units are not surveyed. Form EIA-867 is a mandatory survey of all existing and planned nonutility electric generating facilities in the United States with a total generator nameplate capacity of 1 megawatt or more. In 1992, the reporting threshold for Form ELA-867 was lowered to include all facilities with a combined nameplate capacity of 1 megawatt or more. Previously, data were collected every 3 years from facilities with a nameplate capacity between 1 and 5 megawatts. This has the effect of making the data prior to 1993 slightly less accurate.

\footnotetext{
${ }^{252}$ Even if stock data are only approximate, conventional energy stocks are normally a small percentage of production.

${ }^{253}$ Information.in this section is based on the report, "Renewable Energy Frame Review. Updated Report: Survey Sampling Frame and Electricity Discrepancy Estimates," by Decision Analysis Corporation of Virginia (Vienna, Virginia, August 1993).

${ }^{254}$ Because the MECS is based on the Bureau of the Census' Annual Survey of Manufacturers, EIA does not know the identity of MECS respondents.
} 
Form EIA-867 coverage is particularly weak for facilities producing electricity from municipal solid waste (MSW). Accordingly, EIA uses information provided by Governmental Advisory Associates (GAA) reports, namely, the "Resource Recovery Yearbook" and "Methane Recovery Yearbook," to develop its wastegenerated electricity estimates.

An analysis of the Form EIA-867 universe indicates that the survey's capacity undercoverage varies between 3 and 10 percent, depending on the fuel source (Table B1). Capacity and unit coverage are the most difficult for wind, where numerous small units exist. EIA has analyzed the differences between capacities reported for identical renewable units on Form EIA-867 and alternative sources. Capacity discrepancies were found to result from four factors:

- Obsolete information.

- Facility versus generator reporting: A non-ELA source may cite capacity figures for an entire facility, not taking into account individual generators that use conventional fuels or a mixture of conventional and renewable fuels.

- Capacity definition differences: Form EIA-867 requests respondents to report nameplate electric capacity. However, alternative capacity measures are being reported on non-EIA data sources.

- Numerical rounding practices: This has the greatest effect on small units.
In a followup study of capacity discrepancies, the EIA867 was over four times more likely to have the correct value than the alternative source, which covered units of all sizes.

ELA has attempted to compare GAA data on MSW with information used by the U.S. Environmental Protection Agency (EPA). However, definitional differences make data quality evaluation difficult.

\section{Non-Electric Renewable Energy Consumption}

\section{Overview}

The primary application for renewable energy other than making electricity is creating heat, for industrial processes, buildings, or water. Most non-electric consumption data are gathered on two EIA consumption surveys: the Manufacturing Energy Consumption Survey (MECS), and the Residential Energy Consumption Survey (RECS). MECS is based on the U.S. Bureau of the Census'. Census of Manufacturing. As far as renewable energy is concerned, MECS provides consumption estimates of total industrial energy and various categories of biomass, including wood. RECS is based on an area probability sample of households selected by EIA. For renewable energy, it provides estimates of residential wood energy consumption.

Table B1. Evaluation of EIA's Undercoverage of Nonutility Electricity Data

\begin{tabular}{|c|c|c|c|}
\hline Fuel & Source & Number of Facilities ${ }^{a}$ & Capacity \\
\hline \multirow[t]{2}{*}{ Biomass ........ } & EIA- $867^{b}(\geq 1 \mathrm{MW})$ & 471 & 14,090 \\
\hline & "Electricity Discrepancy Estimates" & 759 & 15,037 \\
\hline \multirow[t]{2}{*}{ Geothermal .... } & EIA-867 & 48 & 1,551 \\
\hline & "Electricity Discrepancy Estimates" & 57 & 1,590 \\
\hline \multirow[t]{2}{*}{ Wind $\ldots \ldots \ldots$} & EIA-867 & 82 & 1,803 \\
\hline & "Electricity Discrepancy Estimates" & 739 & 1,992 \\
\hline \multirow[t]{2}{*}{ Solar } & EIA-867 & 11 & 365 \\
\hline & "Electricity Discrepancy Estimates" & 152 & 374 \\
\hline
\end{tabular}

Source: Energy Information Administration, Form EIA-867, "Annual Nonutility Power Producer Report."

${ }^{a}$ Excludes some EIA-867 facilities that could not be matched with facilities contained in non-EIA data sources.

bBased upon the 1991 survey year. Excludes some EIA-867 facilities that could not be matched with facilities contained in nonEIA data sources. The 1991 EIA-867 survey did not indicate what nonutility facilities under 5 megawatts are renewable.

cuenewable Energy Frame Review Updated Report: Survey Sampling Frame and Electricity Discrepancy Estimates," by Decision Analysis Corporation of Virginia, August 2, 1993. 
There are two other non-electric applications for renewable energy: solar heating and alcohol transportation fuels. Solar energy for non-electric applications is derived from the EIA Solar Collector Manufacturing Survey, Form EIA-63A/B (formerly CE-63A/B). The survey does not collect energy "consumption," but rather production statistics on various types of solar and photovoltaic energy units. ELA applies additional assumptions regarding their application to estimate the amount of heat energy derived from solar/PV panels installed. (See Chapter 5 for further discussion.) Alcohol fuel consumption information is provided by the Form EIA-819M, "Monthly Oxygenate Telephone Report."

\section{Biomass}

Wood is the principal component of biomass energy. Information on non-electric wood energy consumption is derived from the MECS and RECS surveys.

Although some questions about MECS coverage have been raised, no formal analysis of current data exists to support this concern. According to 1983 U.S. Forest Service statistics on wood harvested for fuelwood, the Pulp and Paper Industry subgroup of the Forest Products Industry group consumed only 42 percent of total sector wood energy, not including black liquor (a byproduct fuel). MECS surveys the smaller-populated Pulp and Paper Industry intensively but only randomly samples the larger-populated remainder of the Forest Products Industry. For a variety of reasons, it is difficult to trace wood energy supply to wood consumed for energy. RECS covers wood consumption only for the primary residence of those surveyed; thus, wood consumption by second homes is omitted. This causes residential wood energy consumption to be understated by about 5 percent.

Cross-checks of Form EIA-819M information on alcohol fuels with data from the Bureau of Alcohol, Tobacco, and Firearms and the U.S. Department of Transportation have not revealed any major deficiencies in the Form EIA-819M data.

\section{Geothermal}

EIA does not collect data on non-electric applications of geothermal energy such as crop drying and groundwater heat pumps. A study prepared for the DOE Office of Energy Efficiency and Renewable Energy, Geothermal Division, indicates that direct uses of geothermal energy, expressed in electric equivalents, amounted to nearly 4.2 gigawatthours in 1993 (Table B2). Sixty percent of this energy was provided by geothermal heat pumps.

\section{Wind, Solar and Photovoltaic}

EIA does not collect information on direct energy uses of wind (e.g., water-pumping). No comprehensive source of such information is known.

The data collected on Forms EIA-63A and EIA-63B are subject to various limitations: (1) coverage (the list of respondents may not be complete or, on the other hand, there may be double counting); (2) nonresponse

Table B2. Geothermal Energy Supplied for Major Direct Use Applications, 1993

\begin{tabular}{|c|c|c|c|c|c|}
\hline Application & $\begin{array}{l}\text { Number of } \\
\text { Projects }\end{array}$ & States $^{a}$ & $\begin{array}{c}\text { Temperature } \\
\text { Range (C) }\end{array}$ & $\begin{array}{c}\text { Capacity } \\
\text { (MW) }\end{array}$ & $\begin{array}{c}\text { Annual Energy } \\
\text { (GW/h/yr) }\end{array}$ \\
\hline Space \& District Heating ${ }^{b} \ldots .$. & 123 & 6 & 26 to 166 . & 169 & 386 \\
\hline Geothermal Heat Pumps . . . . . . & $c_{168,000}$ & 50 & 6 to 39 & 1,733 & 2,403 \\
\hline Greenhouses $\ldots \ldots \ldots \ldots \ldots$ & 38 & 8 & 37 to 110 & 81 & 197 \\
\hline Aquaculture $\ldots \ldots \ldots \ldots \ldots$ & 27 & 9 & 16 to 93 & 104 & 574 \\
\hline Resorts \& Spas $\ldots \ldots \ldots \ldots$. & 190 & 14 & 24 to 93 & 71 & 446 \\
\hline Industrial $\ldots \ldots \ldots \ldots \ldots$ & 12 & 6 & 86 to 154 & 43 & 176 \\
\hline Total .......... & & & & 2,242 & 4,181 \\
\hline
\end{tabular}

Source: P.J. Lienau, J.W. Lund, K. Rafferty, and G. Culver, Reference Book on Geothermal Direct Use, (August 1994), p. 4. ${ }^{a}$ Number of States where projects are located.

DDiffers from 1990 inventory (Lund, 1990) because Mammoth Lakes and Bridgeport geothermal district heating systems were not buill; therefore, they are not included in the inventory.

Number of equivalent 3-ton geothermal heat pump units. 
(some of those surveyed may not respond, or they may not provide all the information requested); and (3) adjustments (errors may be made in estimating values for missing data).

ELA collects solar data only on terrestrial systems; it does not collect data on satellite and military applications. The total value of U.S. photovoltaic shipments in 1995 was $\$ 118$ million. Based on anecdotal information, shipments ranging from about $\$ 85$ million to $\$ 100 \mathrm{mil}-$ lion went for satellite applications. Military applications cannot be estimated due to classified information and budgetary accounting. These figures do not include possible inventories held by distributors, retailers, and installers.

The universe of respondents is a census of those U.S.based companies involved in manufacturing and/or importing solar collectors and photovoltaic cells and modules. Care has been taken to establish the survey frames accurately. The frames of potential respondents are compiled from previous surveys and from information in the public domain. However, because the solar collector and photovoltaic cell and module industries are subject to sporadic entry and exit of manufacturers and importers, the frame may exclude some small companies that have recently entered or reentered the industry.
From 1991 through 1994, EIA received reports from all known potential respondents. During the 1990 Form EIA-63B survey period, however, one photovoltaic manufacturer that was known to have shipped photovoltaic cells and modules during the first half of the year went out of business during the second half, and no data were acquired. For that company, 1990 shipments were estimated at one-half of the shipments reported for 1989.

During 1986, the solar thermal collector manufacturing industry experienced a substantial slowdown in shipments as a result of lower conventional energy prices and the expiration of the solar tax credit at the end of 1985. Reported shipments declined from 16.4 million square feet in 1984 to 4.9 million square feet in 1986. Many of the 1986 shipments probably occurred during the first quarter, as customers took delivery of materials purchased in late 1985, when solar tax credits were still available. Although reported shipments in 1985 were only 68 percent of those reported in 1984, it is likely that actual shipments were higher in 1985, which was believed to be a banner year because of the impending expiration of the energy tax credit. The number of companies reporting 1985 shipments and, therefore, the reported shipments may have been low because many of the companies had gone out of business by the time the survey was conducted (in early 1987) and could not be located. 


\section{Appendix C Geothermal Energy and Geysers}

No two geysers behave in exactly the same way. ${ }^{255}$ Studying the system of underground passages that supplies any one of them is a technological challenge. Geysers are distinct from other subterranean emissions. For example, while a volcano vents molten matter, solid rock and gases are released. On the other hand, fumaroles emit only gases or gases and water, but they do not spit water into the air as do geysers. During a late stage of volcanic activity, fumaroles occur along fissures or in apparently chaotic clusters or fields above hot spots in the mantle. Fumaroles are also sometimes described by the composition of their gases as, for example, in chlorine fumaroles. Although not violent, fumaroles can be dangerous to humans and livestock if hazardous or toxic fumes are inhaled.

Three components must be present for geysers to exist: an abundant supply of water, an intense source of heat, and specialized plumbing. Remote locations or locations legislatively protected from human activity are becoming increasingly important to maintaining geysers. The set of requirements make geysers a rare geological phenomenon. Water is sometimes not available, as in an arid part of the country. Heat may be close to the surface only along a fault line, where a tectonic plate is being subducted, from volcanic activity, or from a hard to explain hot spot. Even if both water and heat are present, the right plumbing is critical.

For water to be spit tens of feet into the air, geyser plumbing must be both water- and pressure-tight. Rhyolite, a volcanic rock high in silica, generally provides the seal. Rhyolite deposits a water-tight seal along the walls of the geyser plumbing. Most of the geyser fields in the world are found in rhyolite, but rhyolite fields are relatively uncommon. The right mixture of water, volcanic heat, and plumbing occurs best at Yellowstone National Park.

\section{Yellowstone National Park, Wyoming}

At Old Faithful in Yellowstone Park, the most famous geyser in the United States, the initial jet rises 10 to 26 feet ( 3 to 8 meters) into the air, erupting at intervals of from 30 to 90 minutes. With each eruption, about 10,000 to 12,000 gallons of water are discharged, some of which rises to heights of 115 to 165 feet (35 to 50 meters) in the geyser jet. The process is repeated, with a predictable time interval between ejections. Earthquakes and other geologic events (e.g., vulcanism, mudslides) can and have altered the conditions and change or destroy geyser activity.

Yellowstone National Park in northwestern Wyoming contains the world's greatest number of geysers in nine geyser basins within the park. Steamboat Geyser, located in the Norris Basin, currently ejects the world's tallest natural spouts of water. Major eruptions of Steamboat Geyser can be over 350 feet tall. The Upper Basin alone contains nearly 180 geysers. With more geysers than the rest of the world's geyser basins combined, Yellowstone is by far the world's largest geyser field.

At the heart of Yellowstone's past, present, and future lies volcanism. About 2 million years ago, then 1.2 million years ago, and then again 600,000 years ago, catastrophic volcanic eruptions occurred here. The latest eruption spewed out nearly 240 cubic miles of debris. What is now the park's central portion then collapsed, forming a 28 - by 47 -mile caldera, or basin. The magmatic heat powering those eruptions still powers the park's famous geysers, hot springs, fumaroles, and mud pots. Earthquakes change eruption patterns whenever they occur, with the pattern change often preceding the earthquake.

If there are geysers nearby, geothermal electricity production depletes the geysers' water and removes some of the available heat, reducing and sometimes destroying geyser activity. As a result, the second- and thirdlargest geyser fields in the United States have ceased spouting. Because of the loss of these geysers, the geothermal energy available in and around the Yellowstone National Park has been legislatively protected.

\section{How Geysers Work}

Throughout the world, various features exhibit geyserlike activity. Many perpetual spouters, hot springs,

${ }^{255}$ J.S. Rinehard, Geysers and Geothermal Energy (New York, NY: Springer-Verlag, 1980), p. v. 
venting hot and cold wells, blow holes, karst water spouts, and fumaroles behave as to be interesting to the geyser researcher and enthusiast. These geysers increasingly must possess a fourth characteristic to exist: protection from human activities, either by legislation or by remoteness. Within the last twenty years, geothermal energy and abundant water have been increasingly harnessed to turn turbines for electricity production. Geothermal electricity can be produced at any site where sufficient heat and water are readily available, and geyser fields are ideal for this type of energy production.

As volcanic activity subsides, igneous rocks in the old magma chamber deep in the Earth remain hot for a million years or more. Descending groundwater mixes with perhaps either 25,000 year-old or even more antique connate water, and as one or the other comes into contact with the hot rock, the water becomes heated and tends to rise again toward the surface along a fault or some other fracture where it forms a thermal spring. Also called a hot or warm spring, thermal springs are at least 14 degrees Fahreriheit (8 degrees Centigrade) higher than the average temperature of the air. Water temperatures in thermal springs range all the way up to the boiling point. These hot springs are often unusually rich in mineral matter because dissolution is more rapid in warm water than in cold water. In some springs the mineral content is said to have medicinal properties. Of the thousands of hot springs in the United States, most are found in the Western mountains. While single geysers are rare, groups of geysers, called geyser fields, are rarer still. There were four geysers fields in 1980 and two in 1996-one in Yellowstone and one in the Aleutian Islands off the Alaska coast.

Warm water geysers and hot springs often dissolve some minerals readily so that in some regions certain characteristic rock deposits can be seen. When large amounts of silica dissolved in underground water are forced to the surface, the silica precipitates, or drops from solution, as the water cools. Initially a colloidal gel forms around the geyser mound, but it eventually consolidates into a noncrystalline form of quartz known as geyserite.

On reaching the surface, calcite dissolved in hot water forms travertine, which is also known as dripstone. Geyser pools, which sometimes form below the mouth of geysers in the geyser crater at the top of the geyser pipe, may be quite beautiful because they reflect differ- ent colors associated with minerals dissolved in the heated water.

Geysers always indicate the presence of either a vapordominated or a water-dominated hydrothermal resource. This has allowed geysers to guide the identification of geothermal locations and the potential of the subterranean energy resource. For example, a total of 356 gravity stations were established in the Crump Geyser area, Oregon, in the mid-1970s. The gravity survey provided background geophysical information to assist in evaluating the area's geothermal resource potential. Standard gravity reduction procedures were used to obtain values of the observed gravity, free air anomaly, and Bouguer anomalies. ${ }^{256}$

However, some water-dominated hydrothermal resources have no obvious surface manifestations, with neither geysers, fumaroles nor hot springs (e.g., eastern side of the Cascade Mountain Range in Oregon). Hydrothermal resources are requisite for geothermal electric generating facilities.

Geysers are surface manifestations of hydrothermal resources, boiling hot springs with a natural system of plumbing and heating that causes intermittent eruptions of water and steam. The word geyser comes from the Icelandic word meaning "to gush." Nearly all the world's true geysers, also known as pulsating springs or gushers, are located in Iceland, New Zealand, and the United States. Though New Zealand and Iceland are known for their geysers, nowhere are there as many as in Yellowstone. Over 400 of the world's 700 active geysers are in Yellowstone National Park, making geysers a very rare geological phenomenon.

Geysers are known for their often spectacular eruptions that throw water and steam high into the air. From an economic and public safety standpoint, some geysers have shown certain precursor activity prior to earthquakes. During the period 1973 to 1991 the interval between eruptions from a periodic geyser in Northern California exhibited precursory variations 1 to 3 days before the three largest earthquakes within a 250-kilometer radius of the geyser. These include the magnitude 7.1 Loma Prieta earthquake of October 18, 1989 for which a similar pre-seismic signal was recorded by a strain meter located halfway between the geyser and the earthquake. ${ }^{257}$

The underground structure of a geyser consists of a crooked tube-like opening that leads from the interior to the ground surface. Several small caverns or

\footnotetext{
${ }^{256}$ D. Plouff, Gravity Data in Crump Geyser Area, Oregon (Menlo Park, CA: U.S. Geological Survey, 1975).

${ }^{257}$ P. Silver and N. Valette-Silver, "Detection of Hydrothermal Precursors to Large Northern California Earthquakes," Science, Vol. 257, No. 5075, pp. 1363-1368.
} 
chambers may be connected to the tube. Groundwater partially fills the tube and some of the connecting caverns. The heated water is trapped under pressure in the crooked tube. ${ }^{258}$ Continued heating produces a water temperature above the boiling point, and the steam so produced develops enough pressure to eject a small amount of water to the surface. This expulsion of water in the initial upsurge reduces pressure on the superheated water in the tube. The reduction in pressure causes the remaining water to boil explosively to the point where it drives a column of water and steam, called the geyser jet, into the air. The eruption continues until water and steam are driven out of the tube and storage caverns.

The hot water, circulating up from great depth, flows into the plumbing system of a geyser. Because this water is many degrees above the boiling point, some of it turns to steam. Meanwhile, additional, cooler water is flowing into the geyser from the porous rocks nearer the surface. The two waters mix as the plumbing system fills.

The steam bubbles formed at depth rise and meet the cooler water. At first, they condense there, but as they do they gradually heat the water. Eventually, these steam bubbles rising from deep within the plumbing system manage to heat the surface water until it also reaches the boiling point. Now the geyser begins to function like a pressure cooker. The water within the plumbing system is hotter than boiling, but "stable" because of the pressure exerted by all the water lying above it.

The filling and heating process continues until the geyser is full or nearly full of water. A very small geyser may take but a few seconds to fill whereas some of the larger geysers take several days. Once the plumbing system is full, the geyser is about ready for an eruption. Often forgotten but of extreme importance is the heating that must occur along with the filling. Only if there is an adequate store of heat within the rocks lining the plumbing system can an eruption last for more than a few seconds. Again, each geyser is different from every other. Some are hot enough to erupt before they are completely full and do so without any preliminary indications of an eruption. Others may be completely full well before they are hot enough to erupt and so may overflow quietly for some time before an eruption occurs. But, eventually, the eruption will take place.

Because the water of the entire plumbing system has been heated to boiling, the rising steam bubbles no longer collapse near the surface. Instead, as more very hot water enters the geyser at great depth, even more and larger steam bubbles form and rise toward the surface. At first, they are able to make it all the way to the top of the plumbing system. But a time will come when there are so many steam bubbles that they can no longer simply float upwards. Somewhere they encounter some sort of constriction or bend in the plumbing. To get by they must squirt through the narrow spot. This forces some water ahead of them and up and out of the geyser.

This initial loss of water reduces the pressure at depth, lowering the boiling point of water already hot enough to boil. More water boils, forming more steam. Soon there is a virtual explosion as the steam expands to over 1,500 times its original, liquid volume. The boiling rapidly becomes violent and water is ejected so rapidly that it is thrown into the air.

The eruption will continue until either the water is used up or the temperature drops below boiling. Once an eruption has ended, the entire process of filling, heating, and boiling will be repeated, leading to another eruption.

\footnotetext{
${ }^{258}$ The boiling point of a liquid is dependent upon the pressure. The boiling point of pure water is $212^{\circ} \mathrm{F}\left(100^{\circ} \mathrm{C}\right)$ at sea level. In Yellowstone, the pressure is lowered because the elevation is about 7,500 feet, and the boiling point of water is only about $199^{\circ} \mathrm{F}\left(93^{\circ} \mathrm{C}\right)$.
} 


\section{Appendix D Environmental Impacts of Geothermal Energy}

Although the elimination of rare geological formations, such as geysers, runs counter to today's attitudes on environmental preservation, atmospherically, geother$\mathrm{mal}$ is a "green" renewable energy resource (Figure D1). Compliance with environmental regulations and legislation throughout the total fuel cycle for geothermal electricity generation facilities is attained with relative ease, due primarily to the minimal emissions from their closed systems.

\section{Figure D1. Carbon Emissions from Energy} Production by Fuel

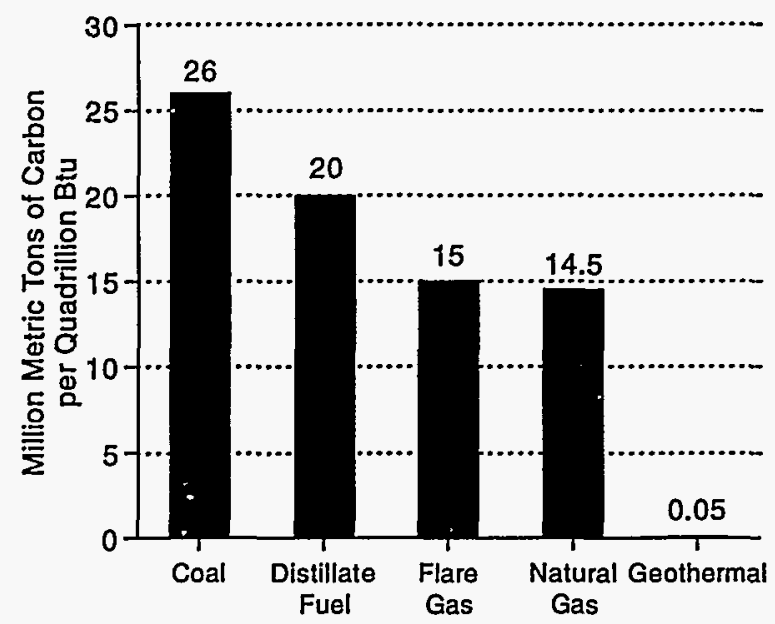

Sources: Geothermal: China Lake Naval Air Weapons Station, Geothermal Program Office (China Lake, CA, 1996). Other Fuels: Energy Information Administration, Emissions of Greenhouse Gases in the United States 1995, DOE/EIA0573(95) (Washington, DC, October 1996), Table B1, p. 98.

In the United States in 1994, electric utilities accounted for 35 percent of the carbon dioxide emissions from fossil energy consumption ${ }^{259}$ and almost 10 percent of the total, ${ }^{260} 66$ percent of the nitrous oxide emissions from stationary sources, ${ }^{261} 70$ percent of U.S. sulfur dioxide emissions (the main cause of acidic precipita- tion), 33 percent of our nitrogen oxide emissions (which induce formation of ground-level ozone), and 20 percent of the anthropogenic releases of gases linked to the atmospheric greenhouse effect.

Development of geothermal energy has a minimal negative impact on the environment compared with development associated with conventional energy sources. Geothermal power plants have sulfur emissions rates that average only a few percent of those from fossil fuel alternatives. The newest generation of geothermal power plants emits only 0.3 pounds of carbon dioxide per megawatthour of electricity generated. Similarly, there are no combustion byproducts (i.e., nitrogen oxide emissions). ${ }^{262}$

In addition, geothermal power plants require relatively little land, taking up only a fraction of that needed by other energy sources. Other land uses can mingle with geothermal plants with little interference or fear of accidents. Geothermal facilities have neither huge piles of ash, nor slag, nor bags of radiation-tainted sulfur to contend with. Containment barriers associated with most fossil-fueled power plants are nonexistent in current designs.

Destruction of rare geyser activity as a result of changing the water levels has proven to be an environmental liability. Electricity generation from geothermal resources has ended the eruptions from the second- and third-largest geyser fields in the 50 States. By 1987, the Beowawe Geyser Field in central Nevada and the Steamboat Springs geyser field, located several miles south of Reno, Nevada, no longer supported geyser activity. ${ }^{263,264}$ No efforts arè underway to stabilize the fields or restart the geysers.

Geothermal resources contribute to energy supplies through both electrical power generation and direct heat uses, and to reduced energy demand through savings in electricity and natural gas that result from the

\footnotetext{
${ }^{259}$ Energy Information Administration, Emissions of Greenhouse Gases in the United States 1987-1994, DOE/EIA-0573(87-94) (Washington, DC, October 1995), p. 12.

${ }^{260}$ Energy Information Administration, Emissions of Greenhouse Gases in the United States 1987-1994, p. ix.

${ }^{261}$ Energy Information Administration, Emissions of Greenhouse Gases in the United States 1987-1994, p. 49.

${ }^{262} \mathrm{Nitrogen}$ oxides combine with hydrocarbon vapors in the atmosphere to produce ground-level ozone, a gas that causes adverse health effects and crop losses as well as smog.

${ }^{263}$ J.S. Rinehart, Geysers and Geothermal Energy (New York, NY: Springer-Verlag, 1980).

${ }^{264}$ The geyser at The Geysers in Northern California was man-made and is not considered part of a geyser field.
} 
use of geothermal heat pumps to heat and cool buildings. Greenhouse gas emissions are almost zero; ozonedepleting chemicals from both direct and indirect sources are also almost zero; sulfur oxide emissions are virtually zero because, by design, geothermal's modern closed-cycle systems reinject almost everything but the extracted heat; and geothermal facilities present light demands on land use, looking much like any light industry facility. 


\section{Appendix E Examples of Contract Arrangements at The Geysers}

The Calpine Corporation has interests in three geothermal power generation facilities ${ }^{265}$ with a total capacity of 67 megawatts and five geothermal steam fields ${ }^{266}$ that supply utility power plants with a total current capacity of approximately 468 megawatts. Steam produced by the geothermal steam fields is sold to utility-owned power plants. The geothermal power generation projects in which the Company has an interest produce electricity, thermal energy and steam that are typically sold pursuant to long-term, take-and-pay power or steam sales agreements generally having original terms of 20 or 30 years.

Revenue from a power sales agreement usually consist of two components: energy payments and capacity payments. Energy payments are based on a power plant's net electrical output with payment rates sometimes determined by a schedule of prices covering a fixed number of years under the power sales agreement, after which payment rates are usually indexed to the fuel costs of the contracting utility or to general inflation indices. Capacity payments are based on either a power plant's net electrical output or its available capacity. Energy payments are made for each kilowatthour of energy delivered, while capacity payments are made whether or not any electricity is delivered. The Company is paid for steam supplied by its steam fields on the basis of the amount of electrical energy produced or steam delivered.

Extensive contractual information is provided in the electronic version of this report (web site www.eia. doe.gov).

\footnotetext{
${ }^{265}$ West Ford Flat: $\$ 167$ per kilowatt per year for 27 megawatts and $\$ 128.90$ per megawatthour. Bear Canyon: $\$ 156$ to $\$ 176$ per kilowatt per year and \$128.90 per megawatthour. Aidlin Facilities: \$167 per kilowatt per year for 17 megawatts and $\$ 128.90$ per megawatthour. ${ }^{266}$ Thermal Power Company Steam Fields: \$16.47 per megawatthour. PG\&E Steam Fields: \$12.07 per megawatthour. SMUD GEO \#1 Steam Fields: $\$ 1.746$ per thousand pounds of steam.
} 


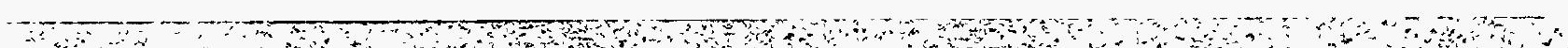




\section{Appendix F Additional Solar and Photovoltaic Tables}

Table F1. Number of Companies Expecting To Introduce New Solar Thermal Collector Products, 1996

\begin{tabular}{c|c}
\hline New Product Type & $\begin{array}{c}\text { Number of } \\
\text { Companies }\end{array}$ \\
\hline Low-Temperature Collectors $\ldots \ldots \ldots$ & 6 \\
Medium-Temperature Collectors $\ldots \ldots$ & 13 \\
High-Temperature Collectors . . . . . & 6 \\
Noncollector Components ........ & 6 \\
\hline
\end{tabular}

Source: Energy Information Administration, Form EIA-63A, "Annual Solar Thermal Collector Manufacturers Survey."

Table F2. Percent of Solar Collector Shipments by the 10 Largest Companies, 1986-1995

\begin{tabular}{|c|c|c|c|c|}
\hline & lear & $\begin{array}{c}\text { Company } \\
\text { Rank }\end{array}$ & $\begin{array}{l}\text { Shipments } \\
\text { (thousand } \\
\text { square feet) }\end{array}$ & $\begin{array}{c}\text { Percent of } \\
\text { Total } \\
\text { Shipments }\end{array}$ \\
\hline 1986 & $\ldots \ldots$ & $\begin{array}{c}1-5 \\
6-10\end{array}$ & $\begin{array}{r}7,771 \\
785\end{array}$ & $\begin{array}{r}83 \\
8\end{array}$ \\
\hline 1987 & $\ldots \ldots$ & $\begin{array}{c}1-5 \\
6-10\end{array}$ & $\begin{array}{r}6,371 \\
499\end{array}$ & $\begin{array}{r}88 \\
7\end{array}$ \\
\hline 1988 & $\ldots \ldots$ & $\begin{array}{c}1-5 \\
6-10\end{array}$ & $\begin{array}{r}7,585 \\
335\end{array}$ & $\begin{array}{r}93 \\
4\end{array}$ \\
\hline 1989 & $\ldots \ldots$ & $\begin{array}{c}1-5 \\
6-10\end{array}$ & $\begin{array}{l}9,748 \\
1,321\end{array}$ & $\begin{array}{l}85 \\
12\end{array}$ \\
\hline 1990 & $\ldots \ldots$ & $\begin{array}{c}1-5 \\
6-10\end{array}$ & $\begin{array}{l}9,955 \\
1,029\end{array}$ & $\begin{array}{r}87 \\
9\end{array}$ \\
\hline 1991 & $\ldots \ldots$ & $\begin{array}{c}1-5 \\
6-10\end{array}$ & $\begin{array}{r}5,429 \\
829\end{array}$ & $\begin{array}{l}83 \\
13\end{array}$ \\
\hline 1992 & $\ldots \ldots$ & $\begin{array}{c}1-5 \\
6-10\end{array}$ & $\begin{array}{r}6,110 \\
609\end{array}$ & $\begin{array}{r}86 \\
9\end{array}$ \\
\hline 1993 & $\ldots \ldots$ & $\begin{array}{c}1-5 \\
6-10\end{array}$ & $\begin{array}{r}6,135 \\
551\end{array}$ & $\begin{array}{r}88 \\
8\end{array}$ \\
\hline 1994 & $\ldots \ldots$ & $\begin{array}{c}1-5 \\
6-10\end{array}$ & $\begin{array}{r}6,401 \\
861\end{array}$ & $\begin{array}{l}84 \\
12\end{array}$ \\
\hline 1995 & $\ldots \ldots$ & $\begin{array}{c}1-5 \\
6-10\end{array}$ & $\begin{array}{r}6,525 \\
806\end{array}$ & $\begin{array}{l}85 \\
11\end{array}$ \\
\hline
\end{tabular}

Note: Totals may not equal sum of components due to independent rounding.

Source: Energy Information Administration: Form EIA-63A, "Annual Solar Thermal Collector Manufacturers Sunvey."
Table F3. Companies Involved in Solar Thermal Activities by Type, 1994 and 1995

\begin{tabular}{l|c|c}
\hline \multicolumn{1}{c|}{ Type of Activity } & 1994 & 1995 \\
\hline Collector or System Design . . . . . . . & 30 & 28 \\
Prototype Collector Development . . . . & 16 & 17 \\
Prototype System Development . . . . . & 16 & 13 \\
Wholesale Distribution . . . . . . . . . . . & 28 & 24 \\
Retail Distribution . . . . . . . . . . . . & 22 & 16 \\
Installation . . . . . . . . . . . . . . & 17 & 15 \\
& & \\
Noncollector System Component . . . . . . . . . . . . & & \\
Manufacture ... . . & & \\
\hline
\end{tabular}

Source: Energy Information Administration, Form EIA-63A, "Annual Solar Thermal Collector Manufacturers Survey."

Table F4. Solar-Related Sales as a Percentage of Total Sales, 1994 and 1995

\begin{tabular}{|c|c|c|}
\hline \multirow{2}{*}{$\begin{array}{c}\text { Solar-Related Sales as a } \\
\text { Percent of Total Sales }\end{array}$} & \multicolumn{2}{|c|}{$\begin{array}{l}\text { Number of } \\
\text { Companies }\end{array}$} \\
\hline & 1994 & 1995 \\
\hline $90-100 \ldots \ldots \ldots \ldots \ldots \ldots$ & 24 & 22 \\
\hline $50-89 \ldots \ldots \ldots \ldots \ldots \ldots$ & 9 & 10 \\
\hline $10-49 \ldots \ldots \ldots \ldots \ldots \ldots \ldots$ & 5 & 0 \\
\hline Less than $10 \ldots \ldots \ldots \ldots \ldots$ & 3 & 4 \\
\hline Total $\ldots \ldots \ldots \ldots \ldots \ldots \ldots$ & 41 & 36 \\
\hline
\end{tabular}

Source: Energy Information Administration, Form EIA-63A, "Annual Solar Thermal Collector Manufacturers Survey." 
Table F5. Annual Shipments of Solar Thermal Collectors by Type, 1986-1995 (Thousand Square Feet)

\begin{tabular}{|c|c|c|c|c|c|c|}
\hline \multirow{2}{*}{\multicolumn{2}{|c|}{ Year }} & \multicolumn{2}{|c|}{ Low-Temperature } & \multicolumn{2}{|c|}{ Medium-Temperature } & \multirow[b]{2}{*}{$\begin{array}{l}\text { High-Temperature } \\
\text { Total Shipments }\end{array}$} \\
\hline & & Total Shipments & $\begin{array}{l}\text { Average per } \\
\text { Manufacturer }\end{array}$ & Total Shipments ${ }^{a}$ & $\begin{array}{l}\text { Average per } \\
\text { Manufacturer }\end{array}$ & \\
\hline 1986 & .. & 3,751 & 171 & 1,111 & 13 & 4,498 \\
\hline 1987 & $\ldots$ & 3,157 & 263 & 957 & 19 & 3,155 \\
\hline 1988 & $\ldots$ & 3,326 & 416 & 732 & 16 & 4,116 \\
\hline 1989 & $\ldots \ldots$ & 4,283 & 428 & 1,989 & 55 & 5,209 \\
\hline 1990 & $\ldots \ldots$ & 3,645 & 304 & 2,527 & 62 & 5,237 \\
\hline 1991 & $\ldots \ldots \ldots$ & 5,585 & 349 & 989 & 24 & 1 \\
\hline 1992 & $\ldots \ldots \ldots$ & 6,187 & 387 & 897 & 26 & 2 \\
\hline 1993 & $\ldots \ldots \ldots$ & 6,025 & 464 & 931 & 28 & 12 \\
\hline 1994 & $\ldots \ldots \ldots$ & 6,823 & 426 & 803 & 26 & 2 \\
\hline 1995 & - & 6,813 & 487 & 840 & 32 & 13 \\
\hline
\end{tabular}

a Includes imputation of shipment data to account for nonrespondents.

bor high-temperature collectors, average annual shipments per manufacturer are not disclosed.

Source: Energy Information Administration, Form EIA-63A, "Annual Solar Thermal Collector Manufacturers Survey."

Table F6. Shipments of Solar Collectors Ranked by Top Five Origins and Destinations, 1994 and 1995

\begin{tabular}{|c|c|c|c|c|}
\hline \multirow[b]{2}{*}{ Origin/Destination } & \multicolumn{2}{|c|}{1994 Shipments } & \multicolumn{2}{|c|}{1995 Shipments } \\
\hline & $\begin{array}{l}\text { Thousand } \\
\text { Square Feet }\end{array}$ & $\begin{array}{l}\text { Percent of } \\
\text { U.S. Total }\end{array}$ & $\begin{array}{l}\text { Thousand } \\
\text { Square Feet }\end{array}$ & $\begin{array}{l}\text { Percent of } \\
\text { U.S. Total }\end{array}$ \\
\hline \multicolumn{5}{|l|}{ Origin $^{a}$} \\
\hline California . . . . . . . . . . . . . . . & 2,074 & 38 & 1,575 & 32 \\
\hline Florida $\ldots \ldots \ldots \ldots \ldots \ldots \ldots \ldots \ldots$ & 194 & 4 & 104 & 4 \\
\hline New Jersey, New York and Puerto Rico . . . . . . . . & 2,563 & 47 & 2,653 & 47 \\
\hline Top Five Total $\ldots \ldots \ldots \ldots \ldots \ldots \ldots$ & 4,831 & 89 & 4,332 & 89 \\
\hline \multicolumn{5}{|l|}{ Destination ${ }^{b}$} \\
\hline Florida $\ldots \ldots \ldots \ldots \ldots \ldots \ldots \ldots \ldots$ & 3,612 & 50 & 3,582 & 50 \\
\hline California . . . . . . . . . . . . . & 1,352 & 19 & 1,420 & 20 \\
\hline Arizona $\ldots \ldots \ldots \ldots \ldots \ldots \ldots \ldots$ & 254 & 4 & 296 & 4 \\
\hline Hawaii $\ldots \ldots \ldots \ldots \ldots \ldots \ldots \ldots$ & 200 & 3 & 219 & 3 \\
\hline Puerto Rico $\ldots \ldots \ldots \ldots \ldots \ldots \ldots \ldots$ & 205 & 3 & 148 & 2 \\
\hline Top Five Total . . . . . . . . . . . . . . . . . . & 5,624 & 78 & 5,655 & 79 \\
\hline
\end{tabular}

${ }^{a}$ Represents only shipments manufactured in the United States.

based on the total shipped each year to the United States and Territories shown in Table F10.

Notes: Totals may not equal sum of components due to independent rounding. U.S. total includes territories.

Source: Energy Information Administration, Form EIA-63A, “Annual Solar Thermal Collector Manufacturers Survey." 
Table F7. Distribution of Solar Thermal Collector Shipments, 1994 and 1995

\begin{tabular}{|c|c|c|}
\hline \multirow[b]{2}{*}{ Recipient } & \multicolumn{2}{|c|}{$\begin{array}{l}\text { Shipments } \\
\text { (thousand square feet) }\end{array}$} \\
\hline & 1994 & 1995 \\
\hline Wholesale Distributors . . . . . & 5,504 & 5,271 \\
\hline Retail Distributors . . . . . . . & 1,406 & 1,659 \\
\hline Exporters ........... & 385 & 279 \\
\hline Installers $\ldots \ldots \ldots \ldots$ & 185 & 251 \\
\hline End Users and Other ${ }^{\mathrm{a}}$. & 146 & 207 \\
\hline Total .......... & 7,627 & 7,666 \\
\hline
\end{tabular}

aOther includes minimal shipments not explained on Form EIA-63A.

Note: Totals may not equal sum of components due to independent rounding.

Source: Energy Information Administration, Form EIA-63A, "Annual Solar Thermal Collector Manufacturers Survey."

Table F8. Solar Thermal Collector Shipments by Type, Quantity, Value, and Average Price, 1994 and 1995

\begin{tabular}{|c|c|c|c|c|c|c|}
\hline \multirow[b]{2}{*}{ Type } & \multicolumn{3}{|c|}{1994} & \multicolumn{3}{|c|}{1995} \\
\hline & $\begin{array}{c}\text { Quantity } \\
\text { (thousand } \\
\text { square feet) }\end{array}$ & $\begin{array}{c}\text { Value } \\
\text { (thousand } \\
\text { dollars) }\end{array}$ & $\begin{array}{c}\text { Average Price } \\
\text { (dollars per } \\
\text { square foot) }\end{array}$ & $\begin{array}{c}\text { Quantity } \\
\text { (thousand } \\
\text { square feet) }\end{array}$ & $\begin{array}{c}\text { Value } \\
\text { (thousand } \\
\text { dollars) }\end{array}$ & $\begin{array}{c}\text { Average Price } \\
\text { (dollars per } \\
\text { square foot) }\end{array}$ \\
\hline \multicolumn{7}{|l|}{ Low-Temperature } \\
\hline $\begin{array}{l}\text { Liquid and Air .............. } \\
\text { Medlum-Temperature }\end{array}$ & 6,823 & 17,241 & 2.53 & 6,813 & 15,756 & 2.31 \\
\hline 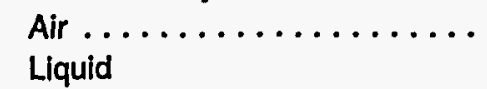 & 3 & 34 & 13.63 & 18 & 271 & 14.77 \\
\hline ICS/Thermosiphon ....... & 215 & 5,615 & 26.10 & 156 & 3,079 & 19.73 \\
\hline Flat Plate $\ldots \ldots \ldots \ldots \ldots$ & 583 & 5,123 & 8.79 & 664 & 5,369 & 8.09 \\
\hline Evacuated Tube $\ldots \ldots \ldots$. & 2 & 112 & 52.91 & 1 & 79 & 58.48 \\
\hline Concentrator $\ldots \ldots \ldots \ldots$ & 1 & 1 & 67.38 & 0 & 1 & 43.33 \\
\hline All Medium-Temperature ..... & 803 & 10,885 & 13.53 & 840 & 8,799 & 10.48 \\
\hline HIgh-Temperature & & & & & & \\
\hline Parabolic Dish and Trough ... & 2 & 28 & 176.99 & 13 & 694 & 53.26 \\
\hline Total .......... & 7,627 & 28,411 & 3.73 & 7,666 & 25,249 & 3.29 \\
\hline
\end{tabular}

ICS = Integral collector storage.

Notes: Totals may not equal sum of components due to independent rounding.

Source: Energy Information Administration, Form EIA-63A, "Annual Solar Thermal Collector Manufacturers Survey." 
Table F9. Shipments of Solar Collectors by Market Sector, End Use, and Tỳpe, 1994 and 1995 (Thousand Square Feet)

\begin{tabular}{|c|c|c|c|c|c|c|c|c|c|}
\hline \multirow[b]{3}{*}{ Type } & \multirow{3}{*}{$\begin{array}{c}\begin{array}{c}\text { Low- } \\
\text { Temperature }\end{array} \\
\text { Liquid/Air } \\
\text { Metallic and } \\
\text { Nonmetallic }\end{array}$} & \multicolumn{5}{|c|}{ Medium-Temperature } & \multirow{3}{*}{$\begin{array}{c}\begin{array}{c}\text { High- } \\
\text { Temperature }\end{array} \\
\text { Parabolic } \\
\text { Dish/Trough }\end{array}$} & \multirow[b]{3}{*}{$\begin{array}{l}1995 \\
\text { Total }\end{array}$} & \multirow[b]{3}{*}{$\begin{array}{l}1994 \\
\text { Total }\end{array}$} \\
\hline & & \multirow[b]{2}{*}{ Air } & \multicolumn{4}{|c|}{ Liquid } & & & \\
\hline & & & $\begin{array}{l}\text { ICS/Ther- } \\
\text { mosiphon }\end{array}$ & $\begin{array}{l}\text { Flat-Plate } \\
\text { (Pumped) }\end{array}$ & $\begin{array}{c}\text { Evacuated } \\
\text { Tube }\end{array}$ & $\begin{array}{c}\text { Concen- } \\
\text { trator }\end{array}$ & & & \\
\hline \multicolumn{10}{|l|}{ Market Sector } \\
\hline Residential ........ & 6,192 & 13 & 150 & 610 & 1 & 0 & 0 & 6,966 & 7,026 \\
\hline Commercial ....... & 552 & 6 & 4 & 41 & * & 0 & 1 & 604 & 583 \\
\hline Industrial $\ldots \ldots \ldots$ & 69 & 0 & 0 & 12 & * & 0 & 0 & 82 & 16 \\
\hline Utility .......... & 0 & 0 & 0 & 0 & * & * & 9 & 9 & 2 \\
\hline Other ${ }^{2} \ldots \ldots \ldots$ & 0 & 0 & 2 & 1 & * & 0 & 3 & 6 & 0 \\
\hline Total . . . . . . . . & 6,813 & 18 & 156 & 664 & 1 & * & 13 & 7,666 & 7,627 \\
\hline \multicolumn{10}{|l|}{ End Use } \\
\hline Pool Heating . . . . . & 6,731 & 6 & 0 & 26 & * & 0 & 0 & 6,763 & 6,813 \\
\hline Hot Water ....... & 11 & 7 & 108 & 627 & 1 & * & 0 & 755 & 790 \\
\hline Space Heating .... & 70 & 5 & 48 & 9 & 0 & 0 & 0 & 132 & 19 \\
\hline Space Cooling .... . & 0 & 0 & 0 & 0 & * & 0 & 1 & 1 & 0 \\
\hline Combined Space and & & & & & & & & & \\
\hline Water Heating $\ldots$. & * & 0 & 0 & 2 & 0 & 0 & 0 & 2 & 4 \\
\hline $\begin{array}{l}\text { Process Heating } \ldots \text {. } \\
\text { Electricity }\end{array}$ & 0 & 0 & 0 & 0 & $\bullet$ & 0 & 0 & * & 0 \\
\hline Generation ....... & 0 & 0 & 0 & 0 & * & $\therefore 0$ & 9 & 10 & 2 \\
\hline Other $^{b} \ldots \ldots \ldots \ldots$ & 0 & 0 - & 0 & 0 & 0 & 0 & 2 & 2 & 0 \\
\hline Total ........... & 6,813 & 18 & 156 & 664 & 1 & * & 13 & 7,666 & 7,627 \\
\hline
\end{tabular}

Less than 500 square feet.

a Other market sectors include shipments of solar thermal collectors to other sectors such as government, including the military but excluding space applications.

'Other end use includes shipments of solar thermal collectors for other uses such as cooking, water pumping, water purification, desalinization, distilling, etc.

ICS = Integral Collector Storage.

Note: Totals may not equal sum of components due to independent rounding.

Source: Energy Information Administration, Form EIA-63A, "Annual Solar Thermal Collector Manufacturers Survey." 
Table F10. Shipments of Solar Thermal Collectors by Destination, 1995 (Square Feet)

\begin{tabular}{|c|c|c|c|}
\hline Destination & 1995 & Destination & 1995 \\
\hline 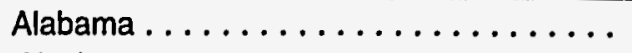 & 2,468 & Nebraska ..................... & 16 \\
\hline Alaska $\ldots \ldots \ldots \ldots \ldots \ldots \ldots$ & 0 & Nevada . . . . . . . . . . . . . . & 143,205 \\
\hline Arizona .................... & 296,466 & New Hampshire . . . . . . . . . . . . . . . . . & 35,984 \\
\hline Arkansas .................... & 3,355 & New Jersey . . . . . . . . . . . . . . . . . & 79,112 \\
\hline California $\ldots \ldots \ldots \ldots \ldots \ldots \ldots$ & $1,420,397$ & New Mexico ..................... . & 26,345 \\
\hline Colorado $\ldots \ldots \ldots \ldots \ldots \ldots \ldots$ & 38,438 & New York ................... & 188,178 \\
\hline Connecticut. ................ & 63,784 & North Carolina . . . . . . . . . . . . . . . & 5,858 \\
\hline Delaware $\ldots \ldots \ldots \ldots \ldots \ldots \ldots \ldots$ & 0 & North Dakota . . . . . . . . . . . . . . . & 0 \\
\hline District of Columbia . . . . . . . . . . & 0 & Ohio $\ldots \ldots \ldots \ldots \ldots \ldots \ldots \ldots$ & 12,606 \\
\hline Florida $\ldots \ldots \ldots \ldots \ldots \ldots \ldots \ldots$ & $3,582,079$ & Oklahoma ................... & 0 \\
\hline Georgia .................. & 61,674 & 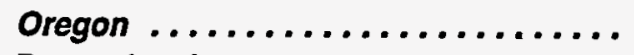 & 184,667 \\
\hline Hawall .................... & 219,303 & Pennsylvania . . . . . . . . . . . . . . & 68,364 \\
\hline 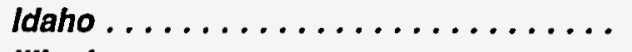 & 0 & Puerto Rico . . . . . . . . . . . . . . & 147,978 \\
\hline Illinols $\ldots \ldots \ldots \ldots \ldots \ldots \ldots \ldots$ & 65,246 & Rhode Island . . . . . . . . . . . . . . & 0 \\
\hline Indlana ................... & 3,455 & South Carolina $\ldots \ldots \ldots \ldots \ldots \ldots \ldots$ & 51 \\
\hline lowa $\ldots \ldots \ldots \ldots \ldots \ldots \ldots$ & 849 & South Dakota . . . . . . . . . . . . . . & 0 \\
\hline Kansas $\ldots \ldots \ldots \ldots \ldots \ldots$ & 3,254 & Tennessee . . . . . . . . . . . . . & 3,368 \\
\hline Kentucky $\ldots \ldots \ldots \ldots \ldots \ldots \ldots$ & 445 & Texas $\ldots . . . \ldots \ldots \ldots \ldots \ldots . . . . . .$. & 73,980 \\
\hline Louisiana $\ldots \ldots \ldots \ldots \ldots \ldots$ & 14,820 & Utah $\ldots \ldots \ldots \ldots \ldots \ldots \ldots \ldots$ & 840 \\
\hline 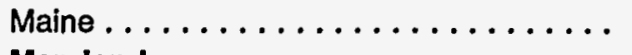 & 23,026 & Vermont $\ldots \ldots \ldots \ldots \ldots \ldots \ldots \ldots$ & 12,652 \\
\hline Maryland $\ldots \ldots \ldots \ldots \ldots \ldots \ldots$ & 2,595 & Virgin Islands (U.S.) $\ldots \ldots \ldots \ldots$. . . . . & 4,605 \\
\hline Massachusetts ................ & 26,982 & Virginia .................. & 16,776 \\
\hline Michigan $\ldots \ldots \ldots \ldots \ldots \ldots \ldots$ & 53,716 & Washington . . . . . . . . . . . . & 21,411 \\
\hline Minnesota $\ldots \ldots \ldots \ldots \ldots \ldots \ldots \ldots$ & 133,085 & West Virginia . . . . . . . . . . . . & 24,450 \\
\hline Mississippi $\ldots \ldots \ldots \ldots \ldots \ldots \ldots \ldots$ & 0 & Wisconsin . . . . . . . . . . . . . & 66,563 \\
\hline Missouri . . . . . . . . . . . . . . & 2,992 & Wyoming $\ldots \ldots \ldots \ldots \ldots \ldots$ & 0 \\
\hline Montana $\ldots \ldots \ldots \ldots \ldots \ldots \ldots$ & 0 & & \\
\hline \multicolumn{3}{|c|}{ 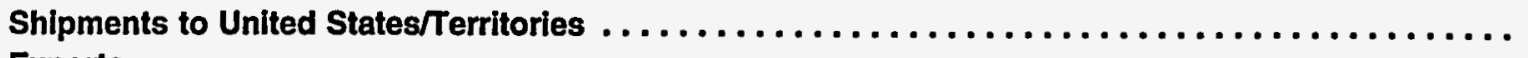 } & $7,135,438$ \\
\hline \multicolumn{3}{|c|}{ 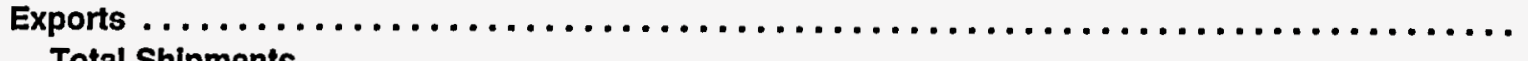 } & 530,473 \\
\hline Total Shipments . . . . . . . . . . . & 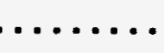 & $\ldots \ldots \ldots \ldots \ldots \ldots \ldots \ldots \ldots \ldots$ & $7,665,911$ \\
\hline
\end{tabular}

Note: Italicized States sponsored incentives for solar thermal collector purchases during 1993 (Solar Energy Industries Association, Solar Industry Joumal, First Quarter 1993, pp. 16-21). States in bold face type sponsored incentives during 1994 (Steve Kalland, Solar Energy Industries Association, personal communication to James Holihan, Energy Information Administration, Washington, DC, June 1, 1994).

Source: Energy Information Administration, Form ElA-63A, "Annual Solar Thermal Collector Manufacturers Survey." 
Table F11. Distribution of U.S. Solar Thermal Collector Exports by Country, 1995

\begin{tabular}{|c|c|}
\hline Country & $\begin{array}{l}\text { Percent of } \\
\text { U.S. Exports }\end{array}$ \\
\hline \multicolumn{2}{|l|}{ Asia and the Middle East } \\
\hline Japan $\ldots \ldots \ldots \ldots \ldots \ldots$ & 1.9 \\
\hline 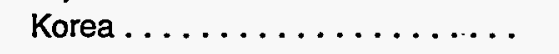 & 0.5 \\
\hline 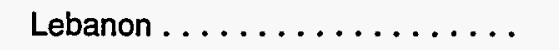 & 0.1 \\
\hline Saudi Arabia $\ldots \ldots \ldots \ldots \ldots$ & 0.1 \\
\hline 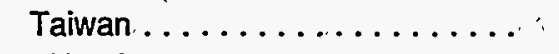 & 15.9 \\
\hline Total $\ldots \ldots \ldots \ldots \ldots \ldots$ & 18.5 \\
\hline \multicolumn{2}{|l|}{ Europe } \\
\hline$\ldots \ldots \ldots \ldots \ldots$ & 2.4 \\
\hline Denmark...$\ldots \ldots \ldots \ldots \ldots$ & 0.5 \\
\hline France $\ldots \ldots \ldots \ldots \ldots \ldots$ & 4.8 \\
\hline Germany $\ldots \ldots \ldots \ldots \ldots$ & 5.6 \\
\hline Netherlands $\ldots \ldots \ldots \ldots \ldots$ & 0.3 \\
\hline Spain $\ldots \ldots \ldots \ldots \ldots \ldots$ & 3.0 \\
\hline Sweden $\ldots \ldots \ldots \ldots \ldots \ldots$ & 4.8 \\
\hline Șwitzerland $\ldots \ldots \ldots \ldots \ldots$ & 1.8 \\
\hline Total $\ldots \ldots \ldots \ldots \ldots \ldots \ldots$ & 23.2 \\
\hline \multicolumn{2}{|l|}{ Africa } \\
\hline South Africa .... & 0.7 \\
\hline Zimbabwe $\ldots \ldots \ldots \ldots \ldots$ & 0.2 \\
\hline Total $\ldots \ldots \ldots \ldots \ldots \ldots \ldots$ & 0.9 \\
\hline Australia $\ldots \ldots \ldots \ldots \ldots \ldots$ & 1.9 \\
\hline \multicolumn{2}{|l|}{ The Americas } \\
\hline Antigua $\ldots \ldots \ldots \ldots \ldots$ & 0.5 \\
\hline Argentina $\ldots \ldots \ldots \ldots \ldots \ldots$ & 0.0 \\
\hline Bahamas ............... & 1.9 \\
\hline Bolivia ............... & 3.7 \\
\hline Canada $\ldots \ldots \ldots \ldots \ldots \ldots$ & 40.8 \\
\hline Costa Rica . . . . . . . . . . . & 0.1 \\
\hline Ecuador ................ & 0.1 \\
\hline Honduras $\ldots \ldots \ldots \ldots \ldots \ldots$ & 0.0 \\
\hline Mexico $\ldots \ldots \ldots \ldots \ldots \ldots$ & 4.3 \\
\hline Montserrat $\ldots \ldots \ldots \ldots \ldots$ & 0.1 \\
\hline St. Kitts $\ldots \ldots \ldots \ldots \ldots \ldots$ & 0.1 \\
\hline St. Martin $\ldots \ldots \ldots \ldots \ldots \ldots$ & 0.2 \\
\hline U.S.Virgin Islands $\ldots \ldots \ldots \ldots$ & 0.3 \\
\hline Total $\ldots \ldots \ldots \ldots \ldots \ldots \ldots$ & 52.1 \\
\hline Other $\ldots \ldots \ldots \ldots \ldots \ldots$ & 3.4 \\
\hline Total $\ldots \ldots \ldots \ldots \ldots \ldots \ldots$ & 100.0 \\
\hline
\end{tabular}

Notes: "Other" represents shipments to countries not disaggregated by companies on Form EIA-63A and may include shipments to enumerated countries. Totals may not equal sum of components due to independent rounding.

Source: Energy Information Administration, Form EIA-63A, "Annual Solar Thermal Collector Manufacturer Survey." 
Table F12. Shipments of Complete Solar Thermal Collector Systems, 1994 and 1995

\begin{tabular}{|c|c|c|}
\hline Shipment Information & 1994 & 1995 \\
\hline Complete Collector Systems Shipped . & 15,946 & 14,121 \\
\hline Thousand Square Feet $\ldots \ldots \ldots \ldots \ldots \ldots$ & 2,763 & 1,551 \\
\hline Percent of Total Shipments & 39 & 20 \\
\hline Number of Companies & 35 & 36 \\
\hline Value of Systems (thousand dollars) $\ldots \ldots \ldots$. & 19,390 & 17,826 \\
\hline
\end{tabular}

Source: Energy Information Administration, Form EIA-63A, "Annual Solar Thermal Collector Manufacturers Survey."

Table F13. Companies Expecting To Introduce New Photovoltaic Products in 1996

\begin{tabular}{|c|c|}
\hline New Product Type & $\begin{array}{l}\text { Number of } \\
\text { Companies }\end{array}$ \\
\hline $\begin{array}{l}\text { Crystalline Sillicon } \\
\text { Single-Crystal Silicon Modules } \ldots \ldots \ldots \ldots \\
\text { Cast Silicon Modules } \ldots \ldots \ldots \ldots \ldots \ldots \ldots \\
\text { Ribbon Silicon Modules } \ldots \ldots \ldots \ldots \ldots\end{array}$ & $\begin{array}{l}4 \\
3 \\
2\end{array}$ \\
\hline $\begin{array}{l}\text { Thin Film } \\
\quad \text { Amorphous Silicon Modules } \ldots \ldots \ldots \ldots \ldots \\
\text { Other (Thin-Film) } \ldots \ldots \ldots \ldots \ldots \ldots \ldots\end{array}$ & $\begin{array}{l}5 \\
3\end{array}$ \\
\hline Other (Flat Plate) $\ldots \ldots \ldots \ldots \ldots \ldots$ & 0 \\
\hline $\begin{array}{l}\text { Concentrators } \ldots \ldots \ldots \ldots \ldots \ldots \ldots \ldots \\
\text { Nonmodule System Components . . . . . . }\end{array}$ & $\begin{array}{l}2 \\
2 \\
\end{array}$ \\
\hline
\end{tabular}

Source: Energy Information Administration, Form ElA-63B, "Annual Photovoltalc Module/Cell Manufacturers Survey."

Table F14. Employment in the Photovoltaic Manufacturing Industry, 1990-1995

\begin{tabular}{|c|c|c|c|}
\hline & Year & $\begin{array}{l}\text { Number of } \\
\text { Companies }\end{array}$ & $\begin{array}{c}\text { Number of } \\
\text { Person-Years }\end{array}$ \\
\hline 1990 & & 19 & 1,622 \\
\hline 1991 & 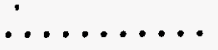 & 23 & 1,588 \\
\hline 1992 & & 21 & 1,463 \\
\hline 1993 & & 19 & 1,431 \\
\hline 1994 & & 22 & 1,312 \\
\hline 1995. & $\cdots$ & 24 & 1,578 \\
\hline
\end{tabular}

Source: Energy Information Administration, Form EIA-63B, "Annual Photovoltaic Module/Cell Manufacturers Survey."
Table F15. Number of Companies Involved in Photovoltaic-Related Activities, 1994 and 1995

\begin{tabular}{|c|c|c|}
\hline \multirow[b]{2}{*}{ Type of Activity } & \multicolumn{2}{|c|}{$\begin{array}{l}\text { Number of } \\
\text { Companles }\end{array}$} \\
\hline & 1994 & 1995 \\
\hline Cell Manufacturing . . . . . . . . . . & 12 & 14 \\
\hline Module or System Design ... & 19 & 19 \\
\hline Prototype Module Development . . . & 18 & 17 \\
\hline Prototype Systems Development .. & 14 & 14 \\
\hline Wholesale Distribution . . . . . . . . & 10 & 14 \\
\hline Retail Distribution . . . . . . . . . & 9 & 6 \\
\hline Installation $\ldots \ldots \ldots \ldots \ldots \ldots$ & 10 & 8 \\
\hline $\begin{array}{l}\text { Noncollector System } \\
\text { Component Manufacturing . . . . . . . }\end{array}$ & 8 & 5 \\
\hline
\end{tabular}

Source: Energy Information Administration, Form EIA-638, "Annual Photovoltaic Module/Cell Manufacturers Survey." 
Table F16. Photovoltaic Cell and Module Shipments by Type, 1993-1995

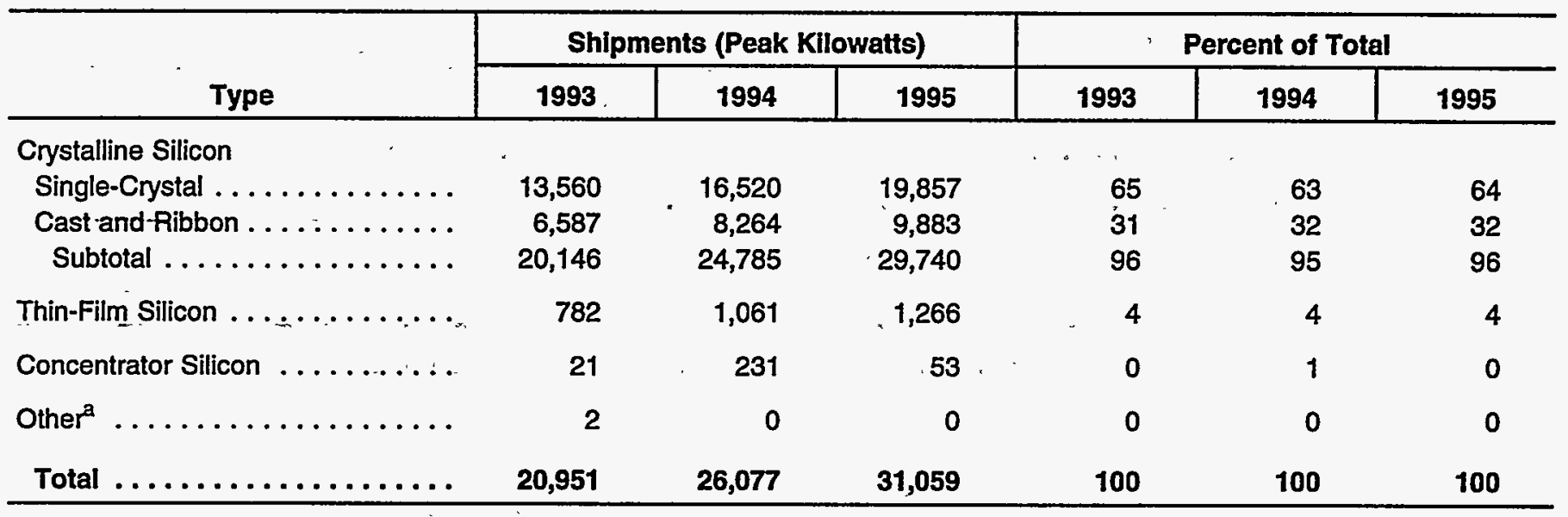

ancludes categories not identified by reporting companies.

Notes: Data do not include shipments of cells and modules for space/satelite applications. Totals may not equal sum of components due to independent rounding.

Source: Energy Information Administration, Form ElA-63B, "Annual Photovoltaic Module/Cell Manufacturers Survey."

Table F17. Distribution of Photovoltaic Cells and Modules, 1993-1995

\begin{tabular}{|c|c|c|c|}
\hline \multirow{2}{*}{ Recipient } & \multicolumn{3}{|c|}{ Shipments (Peak Kilowatts) } \\
\hline & 1993 & 1994 & 1995 \\
\hline Wholesale Distributors $\ldots \ldots \ldots \ldots \ldots \ldots \ldots$ & 10,354 & 13,248 & 16,413 \\
\hline Retail Distributors $\ldots \ldots \ldots \ldots \ldots \ldots \ldots \ldots \ldots$ & 862 & 1,230 & 1,181 \\
\hline Exporters $\ldots \ldots \ldots \ldots \ldots \ldots \ldots \ldots \ldots \ldots \ldots \ldots$ & 151 & 17 & 321 \\
\hline Installers $\ldots \ldots \ldots \ldots \ldots \ldots \ldots \ldots \ldots \ldots \ldots$ & 1,278 & 2,443 & 4,098 \\
\hline 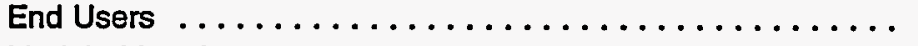 & 2,295 & 1,892 & 458 \\
\hline Module Manufacturers $\ldots \ldots \ldots \ldots \ldots \ldots \ldots \ldots \ldots$ & 5,256 & 6,174 & 5,794 \\
\hline Other $^{\mathrm{a}} \ldots \ldots \ldots \ldots \ldots \ldots \ldots \ldots \ldots \ldots \ldots$ & 754 & 1,073 & 2,793 \\
\hline Total $\ldots \ldots \ldots \ldots \ldots \ldots \ldots \ldots \ldots \ldots \ldots$ & 20,951 & 26,077 & 31,059 \\
\hline
\end{tabular}

${ }^{a}$ Other includes categories not identified by reporting companies.

Note: Totals may not equal sum of components due to independent rounding.

Source: Energy Information Administration, Form ElA-63B, "Annual Photovoltaic Module/Cell Manufacturers Survey." 
Table F18. Photovoltaic Cell and Module Shipments by Type, 1994 and 1995

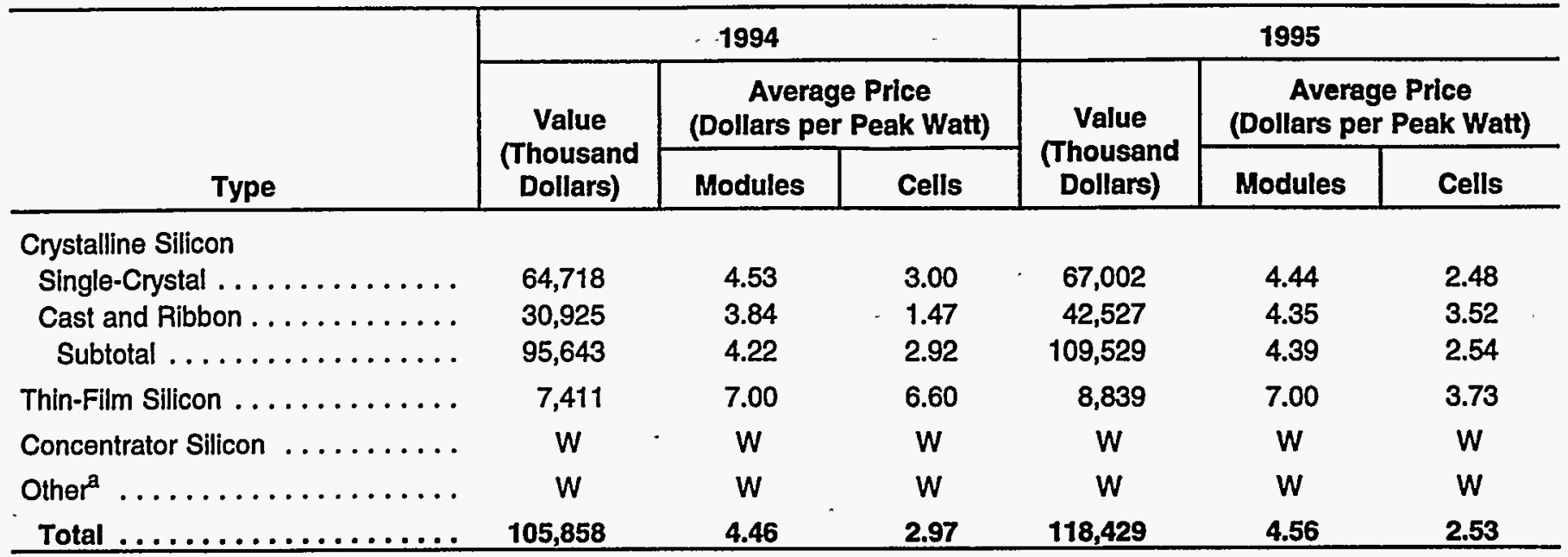

Includes categories not Identified by reporting companies.

$W=$ Data withheld to avoid disclosure of proprietary company data.

Notes: Data do not include shipments of cells and modules for space/satellite applications. Totals may not equal sum of components due to independent rounding.

Source: Energy Information Administration, Form ElA-63B, "Annual Photovoltaic Module/Cell Manufacturers Survey."

Table F19. Shipments of Photovoltaic Cells and Modules by Market Sector, End Use, and Type, 1994 and 1995 (Peak Kilowatts)

\begin{tabular}{|c|c|c|c|c|c|c|}
\hline Sector and End Use & $\begin{array}{l}\text { Crystalline } \\
\text { Silicon }^{\mathrm{a}}\end{array}$ & $\begin{array}{l}\text { Thin-Film } \\
\text { Sillcon }\end{array}$ & $\begin{array}{l}\text { Concentrator } \\
\text { Sillicon }\end{array}$ & Other & 1995 Total & 1994 Total \\
\hline \multicolumn{7}{|l|}{ Market Sector } \\
\hline Industrial & 6,981 & 217 & 0 & 0 & 7,198 & 6,855 \\
\hline Residential .............. & 6,226 & 31 & 15 & 0 & 6,272 & 6,632 \\
\hline Commercial ............. & 7,784 & 286 & 30 & 0 & 8,100 & 5,429 \\
\hline Transportation ........... & 2,140 & 243 & 0 & 0 & 2,383 & 2,174 \\
\hline Utility $\ldots \ldots \ldots \ldots \ldots \ldots$ & 3,724 & 28 & 7 & 0 & 3,759 & 2,364 \\
\hline Government ${ }^{b} \ldots \ldots \ldots \ldots$ & 1,979 & 20 & 1 & 0 & 2,000 & 2,114 \\
\hline Other $\ldots . .$. & 906 & 441 & 0 & 0 & 1,347 & 510 \\
\hline Total $\ldots \ldots \ldots \ldots \ldots \ldots$ & 29,740 & 1,266 & 53 & $\mathbf{0}$ & 31,059 & 26,077 \\
\hline End Use & & & & & & \\
\hline Electricity Generation & & & & & & \\
\hline Grid Interactive . . . . . . . . . & 4,423 & 157 & 5 & 0 & 4,585 & 2,296 \\
\hline Remote $\ldots \ldots \ldots \ldots \ldots$ & 7,993 & 222 & 18 & 0 & 8,233 & 9,253 \\
\hline Communications ........... & 5,140 & 14 & 0 & 0 & 5,154 & 5,570 \\
\hline Consumer Goods .......... & 1,013 & 12 & 0 & 0 & 1,025 & 3,239 \\
\hline Transportation ........... & 4,049 & 154 & 0 & 0 & 4,203 & 2,128 \\
\hline Water Pumping . . . . . . . & 2,680 & 47 & 0 & 0 & 2,727 & 1,410 \\
\hline Cells/Modules to OEM ${ }^{\mathrm{d}} \ldots . .$. & 2,622 & 565 & 0 & 0 & 3,188 & 1,849 \\
\hline Health $\ldots . . \ldots \ldots \ldots \ldots$ & 775 & 1 & 0 & 0 & 776 & 79 \\
\hline Other & 1,045 & 95 & 30 & 0 & 1,170 & 254 \\
\hline Total $\ldots \ldots \ldots \ldots \ldots \ldots$ & 29,740 & 1,266 & 53 & $\mathbf{0}$ & 31,059 & 26,077 \\
\hline
\end{tabular}

Includes single-crystal and cast and ribbon types.

Includes Federal, State, and local govemments, excluding military.

'Other includes shipments that are manufactured for private contractors for research and development projects.

'Original equipment manufacturers.

OOther uses include shipments of photovoltaic cells and modules for other uses, such as cooking food, desalinization, distilling, etc.

Source: Energy Information Administration, Form EIA-63B, "Annual Photovoltaic Module/Cell Manufacturers Survey." 
Table F20. Export Shipments of Photovoltaic Modules and Cells by Type, 1995 (Peak Kilowatts)

\begin{tabular}{c|r|c|c|r}
\hline \multirow{2}{*}{ Item } & \multicolumn{4}{|c}{ Type } \\
\cline { 2 - 5 } & Crystalline Silicon & Thin-Film Sllicon & Concentrator Sillicon & \multicolumn{1}{c}{ Total } \\
\hline Modules $\ldots \ldots \ldots \ldots$ & 10,928 & 365 & 6 & 11,299 \\
Cells $\ldots \ldots \ldots \ldots \ldots$ & 8558 & 14 & 0 & 8,572 \\
Total $\ldots \ldots \ldots \ldots$ & 19,486 & 379 & 6 & 19,871 \\
\hline
\end{tabular}

Source: Energy Information Administration, Form ElA-63B, "Annual Photovoltaic Modula/Cell Manufacturers Survey."

Table F21. Destination of Photovoltaic Cell and Module Exports by Continent, 1995

\begin{tabular}{|c|c|}
\hline Continent & Percent of Exports \\
\hline Africa $\ldots \ldots \ldots \ldots \ldots \ldots \ldots$ & 8.9 \\
\hline Asia $\ldots \ldots \ldots \ldots \ldots \ldots \ldots$ & 48.5 \\
\hline Australia . . . . . . . . . & 0.1 \\
\hline Europe .............. & 28.2 \\
\hline North America $\ldots \ldots \ldots \ldots$ & 5.7 \\
\hline South America $\ldots \ldots \ldots \ldots \ldots$ & 9.6 \\
\hline Total . . . . . . . . . . . . . & 100.0 \\
\hline
\end{tabular}

Source: Energy Information Administration, Form ElA-63B, "Annual Photovoltaic Module/Cell Manufacturers Survey."

Table F22. Shipments of Complete Photovoltaic Module Systems, 1993-1995

\begin{tabular}{|c|c|c|c|}
\hline Shipment Information & 1995 & 1994 & 1993 \\
\hline Complete Photovoltaic Module Systems Shipped & 1,077 & 2,350 & 447 \\
\hline Péak Kilowatts & 937 & 1,015 & 1,395 \\
\hline Percent of Total Shipments $\ldots \ldots \ldots \ldots \ldots \ldots \ldots \ldots \ldots \ldots \ldots \ldots \ldots \ldots \ldots \ldots \ldots$ & 6 & 12 & 9 \\
\hline Value of Systems (thousand dollars) & 6,414 & 1,009 & 14,123 \\
\hline
\end{tabular}

Source: Energy Information Administration, Form EIA-63B, "Annual Photovoltaic Module/Cell Manufacturers Survey." 


\section{Appendix G Moody's Bond Ratings}

Moody's ratings provide investors with a simple system of gradation by: which the relative investment qualities of debt instruments may be noted.

There are nine basic rating categories for long-term obligations. They range from $\mathbf{A c a}$ (highest quality) to $\boldsymbol{C}$ (lowest quality). Those bonds in the Aa, A, Boa, Ba and B groups that Moody's believes possess the strongest investment attributes are designated by the symbols $A \boldsymbol{A}, \mathbf{A T}$, Eadi, Dal and B1. Advance refunded issues that are secured by escrowed funds held in cash, held in trust, reinvested in direct noncallable United States govemment obligations or non-callable obligations unconditionally guaranteed by the U.S. govemment are identified with a \# (hatchmark) symbol, eg. \# Aad.

There are four rating categories for short-term obligations that define an investment grade situation. These are designated Moody's Investment Grade as MIG 1 (best quality) through MIG 4 (adequate quality). Shortterm obligations of speculative quality are designated SG.

In the case of variable rate demand obligations (VRDOs), a twocomponent rating is assigned. The first element represents an evaluation of the degree of risk associated with scheduled principal and interest payments, and the other represents an evaluation of the degree of risk associated with the demand feature. The short-term rating assigned to the demard feature of VRDOs is designated as VMIG. When either the long-or short-term aspect of a VRDO is not rated, that piece is designated NR, e.g., NaANR or NRNMLG 1.

Issues that are subject to a periodic reoffer and resale in the secondary market in a "dutch auction" are assigned a long-term rating based only on Moody's assessment of the ability and willingness of the issuer to make timely principal and interest payments. Moody's expresses no opinion as to the ability of the holder to sell the security in a secondary market "dutch auction." Such issues are identified by the insertion of the words "dutch auction" into the name of the issue.

$\frac{\text { Definitions of Bond Ratings }}{\text { Aaa }}$

Bonds that are rated Aar are judged to be of the best quality. They carry the smallest degree of investment risk and are generally referred to as "gilt edge." Interest payments are protected by a large or by an exceptionally stable margin and principal is secure. While the various protective elements are likely to change, such changes as can be visualized are most unlikely to impair the fundamentally strong position of such issues.

\section{Aa}

Bonds that are rated $\mathbf{A} \mathbf{a}$ are judged to be of high quality by all standards. Together with the Aaa group they comprise what are generally known as high grade bonds. They are rated lower than the best bonds because margins of protection may not be as large as in Aad securitics or fluctuation of protective elements may be of greater amplitude or there may be other elements present that make the longterm risks appear somewhat larger than in Aod securities.

\section{A}

Bonds that are ruted $\mathbf{A}$ possess miany favorable investment attributes and are to be considered as upper medium grade obligations. Factors giving security to principal and interest are considered adequate, but elements may be present that suggest a susceptibility to impairment some time in the furure.

\section{Eara}

Bonds that are rated Boa are considered as medium grade obligations, i.e., they are neither highly protected nor poorly secured. Interest payments and priticipal security appear adequate for the present but certain protective elements may be lacking or may be characteristically unreliable over any great length of time. Such bonds lack outstanding investment characteristics and in fact have speculative characteristics as well.

\section{8}

Bonds that are rated Ba are judged to have speculative elements: their future cannot be considered as well assured. Often the protection of interest and principal payments may be very moderate, and thereby not well safeguarded during both good and bad times over the future. Uncertainty of position characterizes bonds in this class.

\section{8}

Bonds that are rated $B$ generally lack characteristics of the desirable investment. Assurance of interest and principal payments or maintenance of other terms of the contractover any long period of time may be small.

\section{cad}

Bonds that are rated Cad are of poor standing. Such issues may be in default or there may be present elements of danger with respect to principal or interest.

Ca

Bonds that are rated Ca represent obligations that are speculative in a high degree. Such issues are often in default or have other marked shortcomings.

\section{c}

Bonds that are rated $\mathbf{C}$ are the lowest rated class of bonds, and issues so rated can be regarded as having extremely poor prospects of ever attaining any real investment standing.

\section{Con. (...)}

Bonds for which the security depends upon the completion of some act or the fulfillment of some condition are rated conditionally. These are bonds secured by: (a) earnings of projects under construction. (b) earnings of projects unseasoned in operating experience. (c) rentals that begin when facilities are completed, or (d) payments to which some other limiting condition attaches. Parenthetical rating denotes probable credit stature upon completion of construction or elimination of basis of condition.

\section{Definitions of Short-Term Loan Ratings}

Issues or the features associated with MIG or VMIG ratings are identified by date of issue, date of maturity or maturities or rating expiration date and description to distinguish each rating from other ratings. Each rating designation is unique with no implication as to any other similar issue of the same obligor. MIG ratings lerminate at the relirement of the obligation while VAIG rating expiration will be a function of each issue's specific structural or credit features.

\section{MIG 1NMIG I}

This designation denotes best quality. There is present strong protection by established cash flows, superior liquidity support or demonstrated broad-based access to the market for refinancing.

\section{MIG 2NMIG 2}

This designation denotes high quality. Margins of protection are ample although not so large as in the preceding group.

\section{Mis 3 NMIG 3}

This designation denotes favorable quality. All security clements are accounted for but there is lacking the undeniable strength of the preceding grades. Liquidity and cash flow protection may be narrow and market access for refinancing is likely to be less well established.

\section{MIG 4NMIG 4}

This designation denotes adequate quality. Protection commonly regarded as required of an investment security is present and although not distinctly or predominantly speculative, there is specific risk.

\section{SG}

This designation denotes speculative quality. Debt instruments in this category lack margins of protection. 
$1+3$ 


\section{Appendix H LFG: Commercial Energy Recovery Case Studies}

Industry sources indicate that successful LFG energy recovery projects typically have the following characteristics: $:^{267}$

1. Experienced, professional management

2. Adequate financing which allows as much labor, inventory, and supplies as needed

3. An abundant LFG supply

4. A favorable local marketplace

5. Situation in landfills that remain active for 5 to 10 years or more

6. Contracts for gas rights, power or gas sales, and facility use that are solid and of adequate duration

7. Experienced, continuously available personnel for servicing LFG extraction system and energy conversion system.

The following are cases of LFG-to-energy conversion projects where landfill operators/owners and Government have worked together successfully.

- Riverview, Michigan facility, operated by Detroit Edison. Detroit Edison Company has been involved in the development of landfill gas-to-energy projects since 1986. The Riverview facility has an output of 6.6 megawatts. Since it began commercial operation in 1988, it has generated more than 225,000 megawatthours of electricity. The project has operated safely and reliably. Riverview municipal officials have recognized the facility's valuable service and its numerous environmental benefits, including capture of some 4 billion cubic feet of methane that would have been released into the environment. The Riverview facility expects to collect LFG and produce electricity through the year 2027. Detroit Edison has gone on to pursue similar ventures in California, Florida, Texas, Ohio, and Michigan.

- Short Mountain Landfill project, Eugene, Oregon, operated by Emerald People's Utility District (EPUD). EPUD worked with Lane County, the State of Oregon, and a private investment company to develop a 3.4-megawatt plant at the Short Mountain
Landfill. The plant operates at over 97 percent capacity and provides a profit to EPUD as well as royalty income to the County. Bonneville Power Administration (BPA), in turn, credits EPUD's bill for the power generated by the landfill project.

- I-95 Sanitary Landfill, Fairfax County, Virginia. Under a unique arrangement, a developer owns and operates the energy recovery facility, but Fairfax County retains control of the gas extraction wells. The agreement was structured this way because of the County's concerns about migration and odor control. The County operates the well field for the developer, for a fee, and the developer has rights to a set amount of gas. The I-95 energy recovery facility collects 3.3 million cubic feet per day of LFG and uses 8 internal combustion engines to generate 6 megawatts of electricity for sale to Virginia Power. By adopting a team approach with the developer, the County gained a state-of-the-art energy recovery plant at no cost and maintained control over their landfill gas system.

- Mountaingate Facility, Los Angeles, California. The Mountaingate Landfill was shut down in 1980. Four of the eight canyons filled during that time now support a championship golf course. The Mountaingate control and recovery plant collects 5 million cubic feet of LFG per day. Air Products and Chemical, Inc., operators of the Mountaingate Landfill collection facility, processes the gas on site to remove siloxanes and other impurities using a proprietary process. The purified gas is then piped to the University of California at Los Angeles (UCLA), about 4.5 miles away. UCLA in turn compresses the gas to approximately 500 pounds and blends it with natural gas. The blend is used to fuel two 14.5megawatt combustion turbine generators that provide power for the UCLA campus. No detrimental effects on UCLA's emissions control equipment has been noted in the nearly 2 two years of use.

\footnotetext{
${ }^{267}$ Unless otherwise noted, the information in this appendix was obtained from M. Doorn, J. Pacey, and D. Augenstein, Landfill Gas Energy Utilization Experience: Discussion of Technical and Non-Technical Issues, Solutions, and Trends, EPA-600/R-95-035, prepared by E.H. Pechan and Associates, Inc., for the Air and Energy Engineering Research Laboratory, U.S. Environmental Protection Agency (Washington, DC, March 1995).
} 
- AT\&T Plant, Columbus, Ohio. This plant converted its boilers from natural gas to LFG in 1993. The LFG is transported from a nearby landfill. AT\&T estimates that it saved $\$ 120,000$ by mid-1995 over the cost of natural gas. ${ }^{268}$

${ }^{268}$ D.R. Jones, “Landfill Gas Saving Dollars as Industrial Energy Source," Environment Today, Vol. 6, No. 6 (July 1995), pp. 3, 54. 


\section{Appendix I \\ List of Internet Addresses: Renewable Energy Information by Resource}

\section{Biomass: Wood}

An assessment of woody biomass, community forests, land use and soil. http://www.studli.se/chartwell/MBok/M020000/M020057/T020057.html

Supply of Short Rotation Woody Crop Biomass to the Watts Bar Power Facility This is a brief description of studies that exemplify the methods and approaches that have been developed...

http://www.esd.ornl.gov/iab/iab5-7.htm

standing woody biomass (TREEDYN3*);

http://www.gsf.de/UFIS/ufis/modell60/grs957.html

Biomass Fuel from Woody Crops for Electric Power Generation ORNL-6871 Robert D. Perlack ...

http://www.esd.ornl.gov/BFDP/BFDPMOSAIC/REPSMOS/fuelwood/toc.html

Chemical Nature of Biomass from Semi-Arid Forest Tree Species S5.01-02 Natural Variations in Wood Quality / P5.01-00 Properties and Utilization of Tropical Woods Theme: ...

http://www.metla.fi/conf/iufro95abs/d5pap22.htm

PCSD Agriculture: Biomass PCSD BRIEFING BOOK Sustainable Agriculture BIOMASS ENERGY INITIATIVES PROJECT HISTORY

http://bertha.chattanooga.net/sustain/pcsd_briefing_book/agriculture_biomass.html

http://www.gsf.de/UFIS/ufis/schlag_groessen/schlagwort419.html

\section{Biomass: Biofuels}

The Complete Biofuels Internet List

http://www.biomass.org/sites.html

Biofuels Feedstock Development Program Biofuels Feedstock Development Program To contact the BFDP management team...

http://www.esd.ornl.gov/BFDP/BFDPMOSAIC/abtbfdp.html

Biofuels Resources on the Internet Biofuels Resources on the Internet Associations National Biomass Industries Association Bibliographies and Databases Alternative Fuels Data Center...

http://www.ariadne-t.gr/phaethon/biomass/bresource.html

Biofuels: At the Crossroads Biofuels: At the Crossroads. Strategic Plan for the Biofuels Systems Program, United States Departmentof Energy July 1994 Table of Contents.

http://www.esd.ornl.gov/BFDP/BFDPMOSAIC/doedocs/stratplan/toc.html 
Biofuels Information Network Biofuels Information Network Welcome to the Biofuels Information Network Database Annex Search the ORNL Biofuels

http://dsimd.dsrd.ornl.gov/htmldocs/biofuels/biofuels.htp

Biofuels Biofuels Program...

http://www.nrel.gov/research/industrial_tech/biofuels.html

Biofuels: A Win-Win Strategy Biofuels: A Win-Win StrategyStabilizing Global Climate Change While Achieving a Sustainable Energy Future.

http://www.esd.ornl.gov/BFDP/BFDPMOSAIC/doedocs/biowin/toc.html

Moving Biofuels from Research to Market The Major Issues As the Biofuels Systems Program's technologies mature, the program is shifting its focus from lab-oriented $R \& D$ to market...

http://www.esd.ornl.gov/BFDP/BFDPMOSAIC/doedocs/stratplan/issues.html

Re: Targets for biofuels [Prev][Next][Index][Thread] Re: Targets for biofuels To: bioenergy@crest.org Subject: Re: Targets for biofuels.

http://www.crest.org./renewables/bioenergy-list-archive/msg00786.html

Energy Information on Internet: BIOFUELS INFORMATION NETWORK ECN_logo Energie Informatie via Internet BIOFUELS INFORMATION NETWORK Title Organization: Biofuels System ...

http://blister.ecn.nl/eii/homepgnl/eii_013.html

Biofuels Information Center Biofuels Information Center Welcome to the Biofuels Information Center. The center is operated by the National Renewable Energy Laboratory with ...

http://www.afdc.nrel.gov:70/0/biofuels.html

BiofUELS America's Home Page global2000.net proudly presents... Biofuels America's News Release Desk Biofuels Fact Sheet Biofuels Calendar.

http://www.global2000.net./biofuels/

BIOFUELS REPORTS AND PROJECT BRIEFS BIOFUELS REPORTS AND PROJECT BRIEFS Please note that all the files below require Adobe Acrobat.

http://afdc.nrel.gov:70/0/biofuel/bfreport.html

Re: News update on NREL/Biofuels Funding [Prev][Next][Index][Thread] Re: News update on NREL/Biofuels Funding To: bioenergy@crest.org Subject: Re: News update on NREL/...

http://solstice.crest.org/renewables/bioenergy-list-archive/msg00214.html

Biofuels Feedstock Development Program Biofuels Feedstock Development Program Introduction The Biofuels Feedstock Development Program (BFDP) is a national program of research...

http://www.esd.ornl.gov/annual-reports/FY92/bfdp.html

Biofuels Feedstock Development Program Projects Analysis of Feedstock Production and Environmental Systems in DOE Feasibility Studies Directing Organization: U.S. Department of Energy (DOE)

http://www.esd.ornl.gov/BFDP/BFDPMOSAIC/doedocs/94_95sum/bfdp2.html

News update on NREL/Biofuels Funding [Prev][Next][Index][Thread] News update on NREL/Biofuels Funding To: Bioenergy@Crest.Org Subject: News update on NREL/Biofuels Funding

http://www.crest.org/renewables/bioenergy-list-archive/msg00212.html

Renewable Energy: Biomass and Biofuels Renewable Energy: Biomass and Biofuels

http://lacebark.ntu.edu.au/j_mitroy/sid101/energyfacts/re-bioms.html 
Points of Contact For more information about the Biofuels Systems Program, contact: Biofuels Systems Division U.S. Department of Energy 1000 Independence Avenue, S.W. Washington, DC...

http://www.esd.ornl.gov/BFDP/BFDPMOSAIC/doedocs/stratplan/info.html

2nd European Liquid Biofuels Forum [Prev][Next][Index][Thread] 2nd European Liquid Biofuels Forum To: bioenergy@crest.org Subject: 2nd European Liquid Bi...

http://www.crest.org/renewables/bioenergy-list-archive/msg00159.html

Solar Cooking and Biofuels $=$ Solstice $==$ Renewables $==$ sei $=$ Every day 1 million tons of wood are burned for cooking. This is the rough equivalent of 39 square miles of forest. Solar ...

http://www.crest.org/renewables/sei/solarck.html

Biofuel Database Search Help Biofuels Data Base Search Help The Biofuels Citation data base contains bibliographic references (literature citations and abstracts) to all articles, ...

http://afdc2.nrel.gov:70/0/biofuel/help.html

Biofuels Update, Volume 2, Issue 3 - Summer 1994 Biofuels Update, Volume 2, Issue 3 - Summer 1994 Renewables May Be Required In Reformulated Gasoline

http://afdc2.nrel.gov:70/1/bionews/2-3/bfsum94.html

Biofuels Update Newsletter, Volume 3, Issue 2

http://afdc2.nrel.gov:70/0/bionews/3-2/bio32a.html

BioFUELS America! BIOFUELS FACT SHEET

http://www.albany.global1.net/BioFUELS/biof3.html

Biofuels Update - Volume 3, Issue 1 - Winter 1995 Biofuels Update, Volume 3, Issue 1 - Winter 1995 Pilot Plant Transfers Cellulosic Ethanol Production to Industry

http://afdc2.nrel.gov:70/1/bionews/3-1/bfwin95.html

A Win-Win Strategy Biofuels Reduce CO2 While Promoting Sustainable Economic Growth

http://www.esd.ornl.gov/BFDP/BFDPMOSAIC/doedocs/biowin/winwin.html

Technical Evaluation and Planning Biofuels Strategic Plan Directing Organization: U.S. Department of Energy (DOE). http://www.esd.ornl.gov/BFDP/BFDPMOSAIC/doedocs/94_95sum/techeva2.html

Biofuels

http://www.enc.org/cd/access/msubs/scieco/m36.htm

Publications and Information Sources For more information about the Biofuels Systems Program, contact: Office of Fuels Development U.S. Department of Energy 1000 Independence Avenue, S.W. ...

http://www.esd.ornl.gov/BFDP/BFDPMOSAIC/doedocs/biowin/pubs.html

Atmospheric Science Curriculum Bookmarks Alternative Fuels Biofuels Information http://krusty.eecs.umich.edu/people/jreed/weather/ravenbkms.html

1992 BFDP Annual Report BIOFUELS FEEDSTOCK DEVELOPMENT PROGRAM ANNUAL PROGRESS REPORT FOR 1992 L. L. Wright J. H. Cushman A. R. Ehrenshaft (1) S. B. McLaughlin W. A. McNabb S. A. Martin http://www.esd.ornl.gov/BFDP/BFDPMOSAIC/REPSMOS/92ANREP/92conten.html

biofuels@global2000.net; biofuels@globalone.net; mailto:biofuels@global2000.net

Biofuels Feedstock Interface Effects of Ambient Environment on the Storage of Switchgrass in Kentucky for Biomass-to-Ethanol and Thermochemical Projects Directing Organization: U.S. ...

http://www.esd.ornl.gov/BFDP/BFDPMOSAIC/doedocs/94_95sum/intefac2.html 
Energy Crops Forum Fall 1991 Energy Crops Forum Fall 1991 U.S. Department of Energy, Biofuels Feedstock Development Program at Oak Ridge National Laboratory Energy Crops Forum is published...

http://www.esd.ornl.gov/BFDP/BFDPMOSAIC/ECFMOS/91fall.html

U.S. Department of Energy, Office of Fuels Development The Department of Energy (DOE) is sponsoring research, development, demonstration, and commercialization activities to encourage the use of ...

http://www.esd.ornl.gov/BFDP/BFDPMOSAIC/doedocs/bsd.html

Biofuels Update - Volume. 3, Issue 2 - (Spring 1995)

Volume 3 - Issue 2 - Spring 1995 Volume 3 - Issue 2 - Spring 1995 Biofuels Update - Volume. 3, Issue

http://afdc2.nrel.gov:70/bionews/3-2

Biofuels Feedstock Development Program Management Team and Staff BFDP Cast of CharactersProgram Manager Janet Cushman, (423) 574-7818, hcu@ornl.gov Deputy Program Manager.

http://www.esd.ornl.gov/BFDP/BFDPMOSAIC/mgtteam2.html

Biofuels Update Newsletter, Volume 3, Issue 2 Survey Shows Broad Support for Renewable Energy

http://afdc2.nrel.gov:70/0/bionews/3-2/bio32d.html

Biofuels Update Newsletter, Volume 3, Issue 2 New Market for Ethanol in Aviation A lead phase-out in motor gasoline that began in the late 1970s under a Clean Air Act mandate could affect ...

http://afdc2.nrel.gov:70/0/bionews/3-2/bio32b.html

Overview and Role of Biofuels Systems Division Overview On Earth Day 1993, President Clinton announced that the U.S. would comply with the Rio Accord and bring U.S. greenhouse gas ...

http://www.esd.ornl.gov/BFDP/BFDPMOSAIC/doedocs/biowin/overvu.html

Biofuels Update Newsletter, Volume 3, Issue 2 U.S. Ethanol Production Continues to Grow

http://afdc2.nrel.gov:70/0/bionews/3-2/bio32e.html

Sustainable Energy Energy Agricultural Energy Agricultural Energy Assistance Program, California ALTERNATIVE ENERGY California Energy Commission: Alternative/Renewable Technologies EPA: ...

http://www.netins.net/showcase/s_energy/energy.htm

Alternative Fuel Information Sources Alternative Fuel Information Sources Biodiesel \& Other Bio-Oils American Biofuels Association, 1925 N. Lynn St., Suite 1050, Arlington, VA 22209 Bill ...

http://afdc2.nrel.gov:70/0/misc/contacts/afis_b.html

Energy Crops Forum Winter 1994 Energy Crops Forum Winter 1994 U.S. Department of Energy, Biofuels Feedstock Development Program at Oak Ridge National Laboratory Energy Crops Forum is ...

http://www.esd.ornl.gov/BFDP/BFDPMOSAIC/ECFMOS/94winter.html

Poplar Breeding Projects Poplar Breeding Projects U.S. Department of Energy, Biofuels Feedstock Development Program Technical Management by Oak Ridge National Laboratory In the Pacific ...

http://www.esd.ornl.gov/BFDP/BFDPMOSAIC/misc/poplar.html

National Renewable Energy Laboratories- Biofuels Information Center; The Biofuels Information Center, managed by the National Renewable Energy Laboratory;

http://www.afdc.nrel.gov/0/biofuels.html

BIOFUELS Batch type transesterification process for winter rape oil. Applied engineering in agriculture, $7(6)$, Nov 1991, 711-716. Chicken litter to fuel Suffolk power plant. ...

http://www.aber.ac.uk/ wirwww/update/92/00333.html 


\section{Municipal Solid Waste}

ENVIRONMENTAL STUDIES 17. TOXIC AND SOLID WASTE Most waste produced by preindustrial societies is biodegradable. In industrial societies, much waste is nondegradable ...

http://www.fen.org/fen/ecosystem/wast_po.html

Municipal Solid Waste News News From The World of MSW SWANA Logo Last update on: July 1, 1996

http://www.swana.org/mswweek.htm

Municipal Solid Waste News News From The World of MSW SWANA Logo Contents As Of August 1, 1996: Waste Flow Control/Interstate Waste Transport Legislation Update...

http://swana.org/mswweek.htm

Re: municipal solid waste [Prev][Next][Index][Thread] Re: municipal solid waste To: bioenergy@crest.org Subject: Re: municipal solid ...

http://www.crest.org./renewables/bioenergy-list-archive/msg00485.html

SOE - 4.1.3.2 Municipal Solid Waste Page 219-_-Contents-Next Section---Previous Section Stresses on the Environment_-_Pollution-W-Waste Disposal-_....

http://atlenv.bed.ns.doe.ca/soe/ch4-62.html

Municipal Solid Waste Management Strategy Environmental Protection Last Updated: December 19, 1995

http://www.env.gov.bc.ca/epd/epdpa/mwr/mswms.html

Municipal Solid Waste Landfills

http://www.epa.gov/OSWRCRA/non-hw/muncpl/landfill/

Municipal Solid Waste Landfills EPA

http://www.epa.gov/docs/OSWRCRA/non-hw/muncpl/landfill/index.html

Flow Control and Municipal Solid Waste

http://www.epa.gov/docs/OSWRCRA/non-hw/muncpl/flowctrl/

Applicants' Guide to Municipal Solid Waste Management Financial Assistance Programs The Environmental Protection Compendium Applicants' Guide to Municipal Solid...

http://www.env.gov.bc.ca/ cpr/guidelns/agmswmfa.html

Oxygen-Enriched Cocombustion of Sewage Sludge and Municipal Solid Waste

http://es.inel.gov/techinfo/facts/kocmbust.html

Emission Criteria for Municipal Solid Waste Incinerators The Environmental Protection Compendium Emission Criteria for Municipal Solid Waste Incinerators...

http://www.env.gov.bc.ca/ cpr/criteria/ecmswi.html

Municipal Solid Waste Factbook.

http://www.epa.gov/docs/OSWRCRA/non-hw/muncpl/factbook/

Guide to the Preparation of Regional Solid Waste Management Plans by Regional Districts (Part I)

http://www.env.gov.bc.ca/epd/cpr/guidelns/gprswmp1.html

Reporting on Municipal Solid Waste A local issue EPA Reports...

http://www.epa.gov/docs/OSWRCRA/non-hw/muncpl/reportng/

Landfill Criteria For Municipal Solid Waste The Environmental Protection Compendium

http://www.env.gov.bc.ca/ cpr/criteria/lcmsw.html 


\section{Waste-to-Energy}

Energy from Waste Energy from waste Introduction The UK Government's draft waste management strategy maintains that burning waste of one type or another ...

http://www.wrfound.org.uk/EfW.html

Revised Ash Strategy For Waste-to-energy Facilities

http://pan.cedar.univie.ac.at/arch/enveng-1/95apr/msg00178.html

ECN Bibliotheek: Urban waste generated energy / World Energy Council [WEC] ; team leader S.W.... Uitgegeven/ontvangen publikaties over december 1995 Pub

http://www.ecn.nl/library/aanwinst/aanw1995/a9512114.html

Socially Responsible Business Energy Efficiency

http://www.srb.org/energy.html

Waste to Energy [Prev][Next][Index][Thread] Waste to Energy To: bioenergy@crest.org, santino@ dms01.ineti.pt, owner-bioenergy@crest.org Subject: Waste to

http://solstice.crest.org/renewables/bioenergy-list-archive/msg00197.html

Waste Prevention Saves Energy Waste Prevention Saves Energy H.J.H. Whiffen, J.F.

http://hammock.ifas.ufl.edu/txt/fairs/4133

Archive of postings to DIOXIN-L: Columbus Waste-to-Energy Facility Columbus Waste-to-Energy Facility John Thomas (jnthomas@infinet.com) Sat, 14 Oct 1995 14:38:49 -0400...

http://essential.org/listproc/dioxin-1/0100.html

\section{Geothermal}

http://DOEGeothermal.inel.gov>U.S. DOE/Government

http://www.oit.osshe.edu/ geoheat/other.html>domestic geothermal organizations

http://www.demon.co.uk/geosci/igahome.html>international geothermal organizations

http://www.oit.osshe.edu/ geoheat/art7.html>direct uses of geothermal energy

Summary: Geothermal Heat Pump Systems user interface. About Apogee e-Mail Return to To Geothermal Home Page

http://www.apogee.net/geoshots.htm

Geothermal Theory: Introduction

Summary: How Geothermal Systems Form. Geothermal Occurances Today.

http://www.crest.org/renewables/re-kiosk/geothermal/theory/index.shtml

Summary: IEA CADDET International Information on Geothermal Energy.

3/95 Demonstration of a $100 \mathrm{~kW}$-class Geothermal Power Generation System - Japan.

http://www.caddet.co.uk/geo.htm

Energy Directory - Geothermal Energy

Summary: Heat Flow and the Structure of the GeoSphere, June 10-16, 1996. Geothermal Heat Pump Initiative in the U.S. Geothermal Resources Council (USA) Library \& Information.

http://www.energy.ca.gov/earthtext/other-geothermal.html 
Geothermal Workshop

Summary: The New Zealand Geothermal Workshop is a three-day conference held annually in early November. The Workshop provides an international forum where engineers and earth scientists discuss aspects of geothermal development.

http://www.auckland.ac.nz/gei/workshop.htm

Gridwise: Geothermal

Summary: A comprehensive directory of power generation, transmission, distribution, and end-use.

http://www.gridwise.com/data/z202.htm

Geothermal Links

Summary: GEOTHERMAL LABORATORY GEOTHERMAL LINKS.

Internation Geothermal Association Nappa Valley/Geysers/Geothermal Area Sites/Geyser Resources/ Coso's Geothermal Field/Water Resources of California/Geothermal Resources/ Council World Geothermal Resources/ Maps.

http://www.geology.smu.edu/ bonner/geothermlinks.html

Direct Use (Geothermal): Geographic

http://www.sustainable.doe.gov/database/topic/epst/gec/directgeo/georange.html

Summary: CESD Database: DIRECT USE (GEOTHERMAL): Geographic Range. DIRECT USE (GEOTHERMAL): Geographic Range.

IEA

Summary: Geothermal, solar, etc; indigenous production of geothermal, solar, wind, tide and wave energy and the use of these energy forms for electricity generation. The quantity of geothermal energy entering electricity generation is inferred from the electricity production at geothermal plants assuming an average thermal efficiency of 10 per cent. http://www.iea.org/stats/defs/sources/geo.htm

Geothermal Theory: Geothermal Use Today

Summary: Geothermal power plants now provide more than 2500 megawatts of clean electricity to the U.S., equivalent to three large nuclear power plants. According to the U.S. Energy Information Administration, geothermal has the potential to provide the U.S. with 12,000 megawatts of electricity by the year 2010, and 49,000 megawatts by 2030.

http://www.crest.org/renewables/re-kiosk/geothermal/theory/usetoday.shtml

Heat Pumps (Geothermal):

Summary: CESD Database: HEAT PUMPS (GEOTHERMAL): Geographic Range. HEAT PUMPS (GEOTHERMAL): Geographic Range.

http://www.sustainable.doe.gov/database/topic/epst/gec/heatpump/georange.html

CESD Database: Electriçity Generation

Summary: CESD Database: ELECTRICFTY GENERATION (GEOTHERMAL): Geographị Range. ELECTRICITY GENERATION (GEOTHERMAL): Geographic Range.

http://www.sustainable.doe.gov/database/topic/epst/gec/geoelec/georange.html

District Heating(geothermal)

Summary: - ENERGY PRODUCTION \& STORAGE TOPICS.

http://www.sustainable.doe.gov/database/topic/epst/gec/distheat/all.html

Geothermal Theory, Geothermal Reservoirs: Fractured Rock (2)

Summary: In most high-temperature reservoirs, much of the porosity and permeability exist in natural rockfractures, although they may be artificially induced. In other reservoirs, the space between sand grains in the rock provides ample porosity and permeability.

http://www.crest.org/renewables/re-kiosk/geothermal/theory/fracturedrock2.shtml 
Summary: Overview of the Geothermal Energy Conversion Efforts at NREL; Anderson, J. Title:. Geothermal Energy - The Environmentally Responsible Energy Technology for the Nineties: Proceedings of Geothermal Program Review XI, 27-28 April 1993, Berkeley, California.

http://www.nrel.gov/documents/pubs/Geothermal_Energy.dir/15635.html

Geothermal Energy

Summary: Recent developments in utilizing geothermal energy have beendirected to the deeper resources with the more corrosive substances at thehigher temperature and pressure. The purpose of this study is to examine theperformance of metallic materials in the aggressive flow fields assumed to beinvolved in extracting the deep geothermal energy.

http://www.etl.go.jp:8080/aist/TNIRI/HTMLs/outline/projects/Project1995/Designated_Research/

Geothermal_Energy/EMDGE.html/

CESD Database: DISTRICT HEATING (GEOTHERMAL):

Summary: CESD Database: DISTRICT HEATING (GEOTHERMAL):Geographic Range. DISTRICT HEATING (GEOTHERMAL): GeographicRange.

http://www.sustainable.doe.gov/database/topic/epst/gec/distheat/georange.html

\section{Wind}

Renewable Energy: Wind Renewable Energy: Wind Wind has become a viable source of electric energy for utilities. Utility-scale wind power plants ...

http://nrelinfo.nrel.gov/documents/energy/re-wind.html

03/27/95 Talking Points - 25th Annual Conference U. S. Wind Energy Industry Opening Session Monday, March 27, 1995 8:30 a.m. PRESS AVAILABILITY 25th ANNUAL CONFERENCE U.S. ... http://apollo.osti.gov/html/secretry/tp950327.html

Wind Energy Weekly Contact: tgray@igc.apc.org (Tom Gray) Purpose: Weekly newsletter. http://www.neosoft.com/internet/paml/groups.W/wind_energy_weekly.html

American Wind Energy Association. The 1996 AWEA Directory of Industry Members. This comprehensive, up-to-date reference ircludes contact information as well as product ...

http://www.igc.apc.org/awea/aweapage.html

Alternative Energy Institute Homepage, Wind \& Solar Energy Alternative Energy Institute Introduction to AEI: http://www.wtamu.edu/academic/gradres/aei/

\section{Solar Thermal}

Renewable Energy: Solar Thermal Renewable Energy: Solar Thermal Solar thermal technology converts sunlight into usable forms of heat.

http://info.nrel.gov/documents/energy/re-solar.html

Solar Thermal Engineering Centre Technology Focus Centre Mission Statement http://www.on.ctn.nrc.ca/CONTENT/TYPE_19/P_50/PARENT.HTM

FREQUENTLY ASKED QUESTIONS - SOLAR POWER

http://www.greenpeace.org/ uk/solar/faq2.html

National Solar Thermal Test Facility Sandia National Laboratories Technologies Database SAND No: 93-2848 Revision: 1994 Category: ...

http://www.sandia.gov/ttrans/techdb/Abstracts/93-2848.html 
Implementation of Solar Thermal Technology edited by Ronal Larson and Ronald E. West http://www-mitpress.mit.edu/mitp/recent-books/environ/impl-sol-therm-tech.html

Index of /renewables/re-kiosk/solar/solar-thermal Name Last modified Size Description [DIR] Parent ... http://solstice.crest.org/renewables/re-kiosk/solar/solar-thermal/

Solar Thermal Case Studies A solar thermal water heating system provides St. Rose Hospital in San Antonio, TX. http://solstice.crest.org/renewables/re-kiosk/solar/solar-thermal/case-studies/commercial.shtml

Large Scale Solar Thermal Applications PES operates and maintains Packerland Solar System, the world's largest flat plate...

http://www.netnet.net/energy/page2.html

Future Solar Thermal concentrators Scientists at the University of Chicago have...

http://solstice.crest.org/renewables/re-kiosk/solar/solar-thermal/future/concentrators.shtml

Solar Thermal Case Studies This 10 megawatt solar thermal central receiver power plant.

http://solstice.crest.org/renewables/re-kiosk/solar/solar-thermal/case-studies/central-receiver.shtml

EREN - Solar Thermal Utilization Energy Efficiency and Renewable Energy Network

http://apollo.osti.gov/html/eren/1409.html

Solar Energy An immense amount of energy from the sun strikes the surface of the earth every day.

http://solstice.crest.org/renewables/re-kiosk/solar/index.shtml

EREN - Solar Thermal Power Systems Energy Efficiency and Renewable Ene

http://www.doe.gov/html/eren/1407.html

The National Solar Thermal Test Facility (NSTTF) is operated by Sandia National Laboratories for the U.S. Department of Energy. It...

http://www.sandia.gov/Renewable_Energy/solarthermal/nsttf.html

National Solar Thermal Test Facility Questions Frequently Asked by NSTTF Visitors About Solar Energy How do Central Receiver power plants produce electricity from the heat of...

http://www.sandia.gov/Renewable_Energy/solarthermal/question.html

Solar Radiation and Solar Thermal Systems

Date: Saturday, 20-Jul-96 00:46:40 GMT Last-Modified: Wednesday, 11-Oct-95 14:27:55 GMT Content-type: text/html Content-length: 8514 MS 54 Selected Papers on Solar Radiation and ...

http://www.spie.org/web/abstracts/oepress/MS54.html

Thermal Solar Water Heating in the PAC by: Steve Paradine, Tal Schaeffer, Alek Seelemann, Gerald Van Decker Course:

http://www.adm.uwaterloo.ca/infowast/watgreen/projects/project_records/80.html

Power Partners Successful Solar Thermal Electric Technology The Kramer Junction SEGS projects are a series of utility-scale solar thermal electric power plants ...

http://sierra.ridgecrest.ca.us/kjc/3page2.html

Index (Solar Energy - Thermal) Publications (Solar Energy - Thermal) Economic Status and Prospects of Solar Thermal...

http://info.nrel.gov/documents/pubs/Solar_Energy_-_Thermal.dir/13188.html 
National Solar Thermal Test Facility Sandia National Laboratories Advantages of Using Molten Salt A variety of fluids was tested to transport the sun's heat, including water, air, ...

http://www.sandia.gov/Renewable_Energy/solarthermal/salt.html

Index (Solar Energy - Thermal) Publications (Solar Energy - Thermal) Solar The http://info.nrel.gov/documents/pubs/Solar_Energy_-_Thermal.dir/16395.html

National Solar Thermal Test Facility Sandia National Laboratories Desirable Features of Power Towers for Utilities Because of their practical energy storage, solar power ...

http://www.sandia.gov/Renewable_Energy/solarthermal/feature.html

Index (Solar Energy - Thermal) Publications (Solar Energy - Thermal) Availability of Direct Normal Radiation for Solar

http://www.nrel.gov/documents/pubs/Solar_Energy_-_Thermal.dir/15587.html

Index (Solar Energy - Thermal) Publications (Solar Energy - Thermal) Reflective Coatings for Solar Appli

http://www.nrel.gov/documents/pubs/Solar_Energy_-_Thermal.dir/13629.html

Index (Solar Energy - Thermal) Publications (Solar Energy - Thermal) Advanced Reflector Materials for Solar Concentrator

http://www.nrel.gov/documents/pubs/Solar_Energy_-_Thermal.dir/15646.html

Index (Solar Energy - Thermal) Publications (Solar Energy - Thermal) Computer Design Model for Transpired Solar Collector

http://info.nrel.gov/documents/pubs/Solar_Energy__-_Thermal.dir/16738.html

Index (Solar Energy - Thermal) Publications (Solar Energy - Thermal) Validation of the FLAGSOL Parabolic Trough Solar Power Plant .

http://www.nrel.gov/documents/pubs/Solar_Energy__-Thermal.dir/16729.html

National Solar Thermal Test Facility Sandia National Laboratories Engine Test Facility Test Cell 1

http://www.sandia.gov/Renewable_Energy/solarthermal/engine1.html

Index (Solar Energy - Thermal) Publications (Solar Energy - Thermal) Validation of the FLAGSOL Parabolic Trough Solar Power

http://www.nrel.gov/documents/pubs/Solar_Energy__-Thermal.dir/15924.html

Index (Solar Energy - Thermal) Publications (Solar Energy - Thermal) Thermochemical Cycles for Energy Storage: Thermal Decomposition of...

http://www.nrel.gov/documents/pubs/Solar_Energy_-_Thermal.dir/12332.html

Index (Solar Energy - Thermal) Publications (Solar Energy - Thermal) Applications of Ultra-High Solar Flux; Jenkins, D. Title: Applications of Ultra-Hi...

http://info.nrel.gov/documents/pubs/Solar_Energy_-_Thermal.dir/15584.html

Index (Solar Energy - Thermal) Publications (Solar Energy - Thermal) Solar Regenerative Thermoelectrochemical Converter (RTEC)

http://www.nrel.gov/documents/pubs/Solar_Energy_-_Thermal.dir/12007.html

The Sun's Joules: Solar Thermal, page 634/937

http://www.crest.org/renewables/SJ/solar-thermal/634.html 


\section{Solar Photovoltaic}

http://wwwhost.cc.utexas.edu/ftp/depts/arch/wang/

Centre for Photovoltaic Devices and Systems Home Page http://www.vast.unsw.edu.au/pv.html

Photovoltaic Test and Evaluation Facilities Photovoltaic Test and Evaluation Facilities Sandia National Laboratories Technologies

http://www.sandia.gov/ttrans/techdb/Abstracts/93-2847.html

Power Technology Division PHOTOVOLTAIC GENERATION PHOTOVOLTAIC BRANCH

http://powerweb.lerc.nasa.gov/pv/home.html

Advancing Photovoltaic Technology at NREL's Outdoor Test Facility logo http://www.nrel.gov/lab/pao/otf.html

Photovoltaic Design Assistance Center Sandia National Laboratories Technologies Database http://www.sandia.gov/ttrans/techdb/Abstracts/93-2845.html

Photovoltaic(PV) Module Businesses in the World by Name the Source Renewable Energy Businesses by Product Type Solar Related

http://www.mtt.com/theSource/renewableEnergy/businesses/byP/sRP/pvM/byN/byName.html 



\section{Appendix J State Agencies That Provide Energy Information}

Table J1. List of State Agencies That Provide Energy Information

\begin{tabular}{|c|c|c|}
\hline State & Office & Telephone Number \\
\hline Alaska & State Energy Office & $907-269-4640$ \\
\hline Alaska & $\begin{array}{l}\text { Natural Resources Department } \\
400 \text { Willoughby Ave., 5th Floor } \\
\text { Juneau, AK } 99801\end{array}$ & $907-269-7200$ \\
\hline Arkansas & State Energy Office & $501-682-1370$ \\
\hline California & State Energy Office & $916-654-5000$ \\
\hline California & $\begin{array}{l}\text { Energy Resources, Conservation, and } \\
\text { Development Commission } \\
1516 \text { Ninth St. } \\
\text { Sacramento, CA } 95814\end{array}$ & $916-654-4942$ \\
\hline Colorado & State Energy Office & $303-620-4292$ \\
\hline Connecticut & State Energy Office & 203-566-1559 \\
\hline Delaware & State Energy Office & $302-739-5644$ \\
\hline District of Columbia & State Energy Office & $202-727-4700$ \\
\hline Florida & State Energy Office & $904-488-7400$ \\
\hline Georgia & State Energy Office & $404-656-5176$ \\
\hline Kansas & State Energy Office & $913-271-3170$ \\
\hline Kentucky & State Energy Office & $502-564-7192$ \\
\hline Louisiana & State Energy Office & $504-342-2133$ \\
\hline Maine & State Energy Office & $207-289-6800$ \\
\hline Maryland & State Energy Office & $410-974-3755$ \\
\hline Massachusetts & State Energy Office & $517-727-4732$ \\
\hline
\end{tabular}


Table J1. List of State Agencies That Provide Energy Information

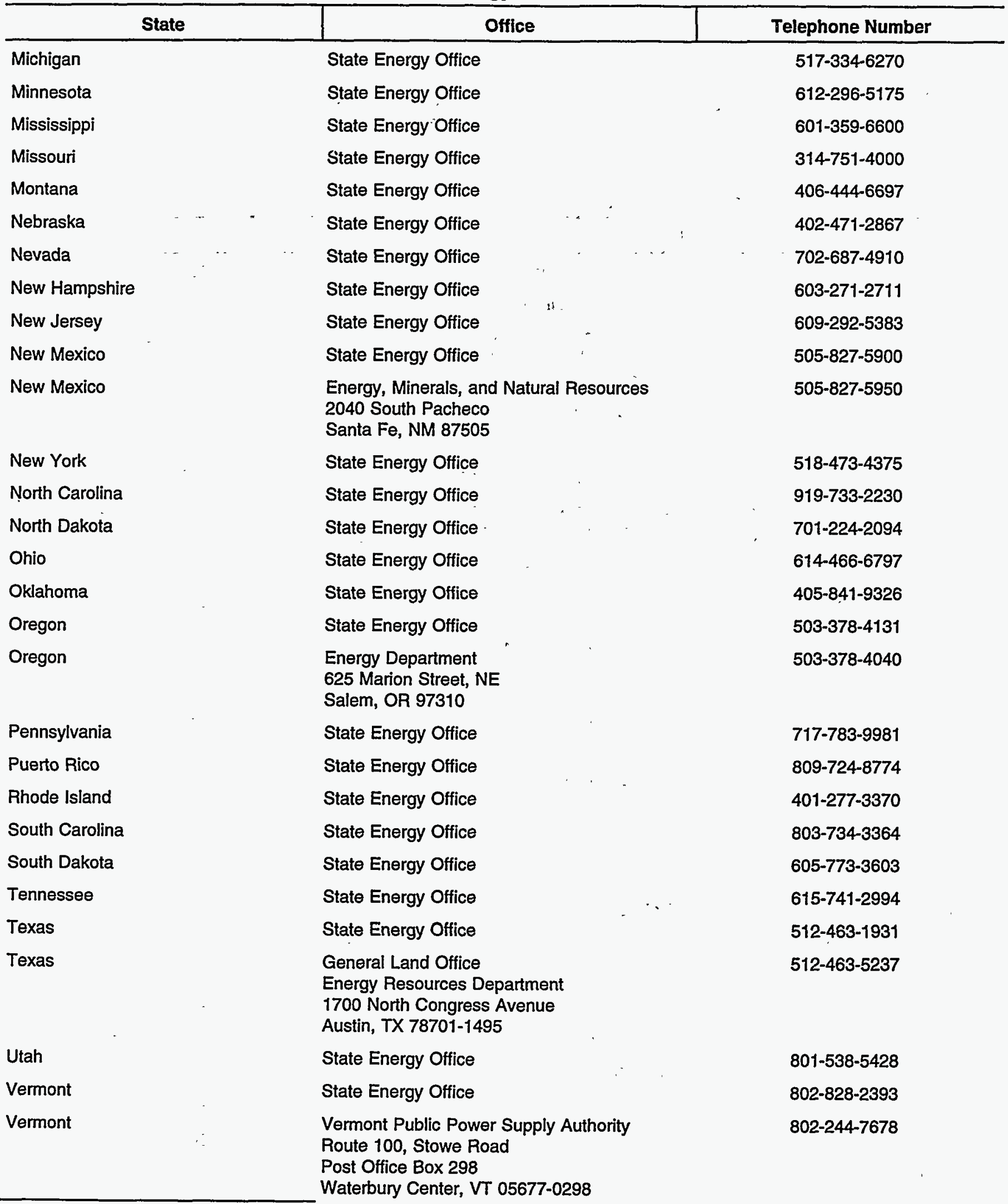


Table J1. List of State Agencies That Provide Energy Information

\begin{tabular}{|c|c|c|}
\hline State & Office & Telephone Number \\
\hline Virgin Islands & Directors Office & $809-772-2616$ \\
\hline Virginia & State Energy Office & $804-692-3218$ \\
\hline Virginia & $\begin{array}{l}\text { State Corporation Commission } \\
\text { Energy Regulations Division } \\
\text { Tyler Building } \\
\text { 1300 East Main Street } \\
\text { Richmond, VA } 23219\end{array}$ & $804-371-9611$ \\
\hline Washington & State Energy Office & $206-956-2000$ \\
\hline Washington & $\begin{array}{l}\text { Energy Office } \\
\text { 925 Plum Street, SE } \\
\text { Building \#4 } \\
\text { Post Office Box } 43165 \\
\text { Olympia, WA } 98504-3165\end{array}$ & $360-356-2000$ \\
\hline West Virginia & State Energy Office & $304-759-0530$ \\
\hline Wisconsin & State Energy Office & $608-266-8234$ \\
\hline Wyoming & State Energy Office & $307-777-7284$ \\
\hline
\end{tabular}

Source: Energy Information Administration, Office of Coal, Nuclear, Electric and Alternate Fuels. 


\section{Glossary}

Acid Rain: Also called "acid precipitation" or "acid deposition," acid rain is precipitation containing harmful amounts of nitric and sulfuric acids formed primarily by nitrogen oxides and sulfur oxides released into the atmosphere when fossil fuels are burned. It can be wet precipitation (rain, snow, or fog) or dry precipitation (absorbed gaseous and particulate matter, aerosol particles, or dust). Acid rain has a pH below 5.6. Normal rain has a $\mathrm{pH}$ of about 5.6, which is slightly acidic. (The $\mathrm{pH}$ value is a measure of acidity or alkalinity, ranging from 0 to 14 . A pH measurement of 7 is regarded as neutral. Measurements below 7 indicate increased acidity, and those above 7 indicate increased alkalinity.)

Alternating Current: An electric current that reverses its direction at regularly recurring intervals, usually 50 or 60 times per second.

Amorphous Silicon: An alloy of silica and hydrogen, with a disordered, noncrystalline internal atomic arrangement, that can be deposited in thin-layers ( $a$ few micrometers in thickness) by a number of deposition methods to produce thin-film photovoltaic cells on glass, metal, or plastic substrates.

Annualized Growth Rates: Calculated as follows:

$$
\left(x_{n} / x_{1}\right)^{1 / n},
$$

where $x$ is the value under consideration and $n$ is the number of periods.

Aquifer: A subsurface rock unit from which water can be produced.

Availability Factor: A percentage representing the number of hours a generating unit is available to produce power (regardless of the amount of power) in a given period, compared to the number of hours in the period.

Avoided Costs: The incremental costs of energy and/or capacity, except for the purchase from a qualifying facility, a utility would incur itself in the generation of the energy or its purchase from another source.

Baghouse: A woven or felted fabric bag-like device that lets gas through but removes suspended particles.

Biomass: Organic nonfossil material of biological origin constituting a renewable energy source.

Biota: The flora and fauna of a region.
Black Liquor: A byproduct of the paper production process that can be used as a source of energy.

Bleached Board: A wood product used for printed and graphically enhanced card stock, books, and packaging such as food cartons, microwave trays, beverages, candy, cosmetics, pharmaceuticals, and consumer electronic items. Pollutants, such as dioxins and furans, can result from processes that use chlorine in the manufacture of bleached board.

Brine: A highly saline solution. A solution containing appreciable amounts of sodium chloride and other salts.

Busbar Cost: The cost per kilowatthour to produce electricity, including the cost of capital, debt service, operation and maintenance, and fuel. The power plant "bus" or "busbar" is that point beyond the generator but prior to the voltage transformation point in the plant switchyard.

Capacity Factor: The ratio of the electrical energy produced by a generating unit for the period of time considered to the electrical energy that could have been produced at continuous full-power operation during the same period.

Capacity, Gross: The full-load continuous rating of a generator, prime mover, or other electric equipment under specified conditions as designated by the manufacturer. It is usually indicated on a nameplate attached to the equipment.

Capital Cost: The cost of field development and plant construction and the equipment required for the generation of electricity.

Cast Silicon: Crystalline silicon obtained by pouring pure molten silicon into a vertical mold and adjusting the temperature gradient along the mold volume during cooling to obtain slow, vertically-advancing crystallization of the silicon. The polycrystalline ingot thus formed is composed of large, relatively parallel, interlocking crystals. The cast ingots are sawed into wafers for further fabrication into photovoltaic cells. Cast-silicon wafers and ribbon-silicon sheets fabricated into cells are usually referred to as polycrystalline photovoltaic cells.

Climate Change (Greenhouse Effect): The increasing mean global surface temperature of the Earth caused by gases in the atmosphere (including carbon dioxide, 
methane, nitrous oxide, ozone, and chlorofluorocarbons). The greenhouse effect allows solar radiation to penetrate the Earth's atmosphere but absorbs the infrared radiation returning to space.

Cogeneration: The production of electrical energy and another form of useful energy (such as heat or steam) through the sequential use of energy.

Combined Cycle: An electric generating technology in which electricity is produced from otherwise lost waste heat exiting from one or more gas (combustion) turbines. The exiting heat is routed to a conventional boiler or to a heat recovery steam generator for utilization by a steam turbine in the production of electricity. Such designs increase the efficiency of the electric generating unit.

Concentrator: A reflective or refractive device that focuses incident insolation onto an area smaller than the reflective or refractive surface, resulting in increased insolation at the point of focus.

Convection: Motion in a fluid or plastic material due to some parts being buoyant because of their higher temperature. Convection is a means of transferring heat through mass flow rather than through simple thermal conduction.

Cull Wood: Wood logs, chips, or wood products that are burned.

Dioxins: A classification of chlorine-containing compounds that are considered extremely toxic carcinogenic agents. Toxic effects include anorexia, hepatotoxicity, chloracne, vascular lesions, and gastric ulcers. Dioxins are byproducts in the manufacture of some chemicals. Causes of dioxin production in combustion begin with chlorine compounds in fuel, inadequate supply of combustion air, too low refractory temperatures, and improper mixing of fuel and air.

Direct Current: An electric current that flows in a constant direction. The magnitude of the current does not vary or has a slight variation.

Electric Utility Restructuring: With some notable exceptions, the electric power industry historically has been composed primarily of investor-owned utilities. These utilities have been predominantly vertically integrated monopolies (combining electricity generation, transmission, and distribution), whose prices have been regulated by State and Federal government agencies. Restructuring the industry entails the introduction of competition into at least the generation phase of electricity production, with a corresponding decrease in regulatory control. Restructuring may also modify or eliminate other traditional aspects of investor-owned utilities, including their exclusive franchise to serve a given geographical area, assured rates of return, and vertical integration of the production process.

Electrostatic Precipitator: A number of vertical, parallel metal plates utilizing the mutual attraction of opposite electric charges to remove dust or ash particles or liquid droplets suspended in a gas.

Emission: The release or discharge of a substance into the environment; generally refers to the release of gases or particulates into the air.

Emissions Trading: With an emissions trading system, a regulatory agency specifies an overall level of pollution that will be tolerated (a cap) and then uses allowances to develop a market to allocate the pollution among sources of pollution under the cap. Emissions permits or allowances become the currency of the market, as pollution sources are free to buy, sell, or otherwise trade permits based on their own marginal costs of control and the price of the permits. In no case can total emissions exceed the cap.

Ethyl Tertiary Butyl Ether (ETBE): A colorless, flammable, oxygenated hydrocarbon $\left(\left(\mathrm{CH}_{3}\right)_{3} \mathrm{COC}_{2} \mathrm{H}_{5}\right)$ blend stock formed by the catalytic etherification of isobutylene with ethanol.

Evacuated Tube: In a solar thermal collector, an absorber tube, which is contained in an evacuated glass cylinder, through which collector fluids flows.

Exempt Wholesale Generator (EWG): A nonutility electricity generator that is not a qualifying facility under the Public Utility Regulatory Policies Act of 1978.

Externalities: Benefits or costs, generated as a byproduct of an economic activity, that do not accrue to the parties involved in the activity. Environmental externalities are benefits or costs that manifest themselves through changes in the physical or biological environment.

Flat Plate Pumped: A medium-temperature solar thermal collector that typically consists of a metal frame, glazing, absorbers (usually metal), and insulation and that uses a pump liquid as the heat-transfer medium: predominant use is in water heating applications.

Flow Control: The laws, regulations, and economic incentives or disiricentives used by waste managers to direct waste generated in a specific geographic area to a designated landfill, recycling, or waste-to-energy facility.

Fuel Cells: One or more cells capable of generating an electrical current by converting the chemical energy of a fuel directly into electrical energy. Fuel cells differ from conventional electrical cells in that the active 
materials such as fuel and oxygen are not contained within the cell but are supplied from outside.

Fuelwood: Wood and wood products, possibly including coppices, scrubs, branches, etc., bought or gathered, and used by direct combustion.

Fumarole: A vent from which steam or gases issue; a geyser or spring that emits gases.

Furans: A class of organic heterocyclic compounds regulated by the U.S. Environmental Protection Agency because of their toxic characteristics. Among other sources, furans can be produced as a byproduct in some pine tar distillation processes. Some derivatives of furans, such as furfuryl alcohol, tetrahydrofurfuryl alcohol, and tetrahydrofuran, are commercially important. Furans can be generated by the same combustion problems described for dioxins.

Generation (Electricity): The process of producing electric energy from other forms of energy; also, the amount of electric energy produced, expressed in watthours (Wh).

Geopressured: A type of geothermal resource occurring in deep basins in which the fluid is under very high pressure.

Geothermal Energy: As used at electric utilities, hot water or steam extracted from geothermal reservoirs in the Earth's crust that is supplied to steam turbines at electric utilities that drive generators to produce electricity.

Geothermal Plant: A plant in which a turbine is driven either from hot water or by natural steam that derives its energy from heat found in rocks or fluids at various depths beneath the surface of the earth. The fluids are extracted by drilling and/or pumping.

Geyser: A special type of thermal spring that periodically ejects water with great force.

Giga: One billion.

Green Liquor: The raw mill effluent that results from the pulping and/or bleaching process in pulp and paper mills. Black liquor can be recovered from green liquor by evaporation and membrane processing.

Green Pricing: In the case of renewable electricity, green pricing represents a market solution to the various problems associated with regulatory valuation of the nonmarket benefits of renewables. Green pricing programs allow electricity customers to express their willingness to pay for renewable energy development through direct payments on their monthly utility bills.

Greenhouse Effect: The increasing mean global surface temperature of the Earth caused by gases in the atmos- phere (including carbon dioxide, methane, nitrous oxide, ozone, and chlorofluorocarbon). The greenhouse effect allows solar radiation to penetrate, but absorbs the infrared radiation returning to space.

Grid: The layout of an electrical distribution system.

Groundwater: Water occurring in the subsurface zone where all spaces are filled with water under pressure greater than that of the atmosphere.

High-Temperature Collector: A solar thermal collector designed to operate at a temperature of 180 degrees Fahrenheit or higher.

Hot Dry Rock: Heat energy residing in impermeable, crystalline rock. Hydraulic fracturing may be used to create permeability to enable circulation of water and removal of the heat.

Hub Heights: In a horizontal-axis wind turbine, the distance from the turbine platform to the rotor shaft.

Hydraulic Fracturing: Fracturing of rock at depth with fluid pressure. Hydraulic fracturing at depth may be accomplished by pumping water into a well at very high pressures. Under natural conditions, vapor pressure may rise high enough to cause fracturing in a process known as hydrothermal brecciation.

Independent Power Producer (IPP): A wholesale electricity producer (other than a qualifying facility under the Public Utility Regulatory Policies Act of 1978), that is unaffiliated with franchised utilities in the area in which the IPP is selling power and that lacks significant marketing power. Unlike traditional utilities, IPPs do not possess transmission facilities that are essential to their customers and do not sell power in any retail service territory where they have a franchise.

Internal Collector Storage (ICS): A solar thermal collector in which incident solar radiation is absorbed by the storage medium.

Kilowatt (kW): One thousand watts of electricity (See Watt).

Kilowatthour (kWh): One thousand watthours.

Levelized Cost: The present value of the total cost of building and operating a generating plant over its economic life, converted to equal annual payments. Costs are levelized in real dollars (i.e., adjusted to remove the impact of inflation).

Liquid Collector: A medium-temperature solar thermal collector, employed predominantly in water heating, which uses pumped liquid as the heat-transfer medium.

Low-Temperature Collectors: Metallic or nonmetallic solar thermal collectors that generally operate at temperatures below 110 degrees Fahrenheit and use 
pumped liquid or air as the heat transfer medium. They usually contain no glazing and no insulation, and they are often made of plastic or rubber, although some are made of metal.

Magma: Naturally occurring molten rock, generated within the earth and capable of intrusion and extrusion, from which igneous rocks are thought to have been derived through solidification and related processes. It may or may not contain suspended solids (such as crystals and rock fragments) and/or gas phases.

Marginal Cost: The change in cost associated with a unit change in quantity supplied or produced.

Mass Burner: A relatively large one-chamber combustion system used to incinerate municipal solid waste under conditions of excess air; it is built on site and consumes fuel without prior processing or sorting.

Medium-Temperature Collectors: Solar thermal collectors designed to operate in the temperature range of 140 degrees to 180 degrees Fahrenheit, but that can also operate at a temperature as low as 110 degrees Fahrenheit. The collector typically consists of a metal frame, metal absorption panels with integral flow channels (attached tubing for liquid collectors or integral ducting for air collectors), and glazing and insulation on the sides and back.

Megawatt (MW): One million watts of electricity (See Watt).

Merchant Facilities: High-risk, high-profit facilities that operate, at least partially, at the whims of the market, as opposed to those facilities that are constructed with close cooperation of municipalities and have significant amounts of waste supply guaranteed.

Methane: The most common gas formed in coal mines; a major component of natural gas.

Methyl Tertiary Butyl Ether (MTBE): A colorless, flammable, liquid oxygenated hydrocarbon $\left(\left(\mathrm{CH}_{3}\right)_{3} \mathrm{COCH}_{3}\right)$ that contains 18.15 percent oxygen and has a boiling point of 55.2 degrees Celsius. It is a fuel oxygenate produced by reacting methanol with isobutylene.

Modular Burner: A relatively small two-chamber combustion system used to incinerate municipal solid waste without prior processing or sorting; usually fabricated at a factory and delivered to the incineration site.

Net Photovoltaic Cell Shipment: The difference between photovoltaic cell shipments and photovoltaic cell purchases.

Net Photovoltaic Module Shipment: The difference between photovoltaic module shipments and photovoltaic module purchases.
Nonutility Generation: Electric generation by endusers, independent power producers, or small power producers under the Public Utility Regulatory Policies Act, to supply electric power for industrial, commercial, and military operations, or sales to electric utilities.

Operation and Maintenance (O\&M) Cost: Operating expenses are associated with operating a facility (i.e., supervising and engineering expenses). Maintenance expenses are that portion of expenses consisting of labor, materials, and other direct and indirect expenses incurred for preserving the operating efficiency or physical condition of utility plants that are used for power production, transmission, and distribution of energy.

Ozone: Three-atom oxygen compound $\left(\mathrm{O}_{3}\right)$ found in two layers of the Earth's atmosphere. One layer of beneficial ozone occurs at 7 to 18 miles above the surface and shields the Earth from ultraviolet light. Several holes in this protective layer have been documented by scientists. Ozone also concentrates at the surface as a result of reactions between byproducts of fossil fuel combustion and sunlight, having harmful health effects.

Parabolic Dish: A high-temperature (above 180 degrees Fahrenheit) solar thermal concentrator, generally bowlshaped, with two-axis tracking.

Parabolic Trough: A high-temperature (above 180 degrees Fahrenheit) solar thermal concentrator with the capacity for tracking the sun using one axis of rotation.

Particulates: Visible air pollutants consisting of particles appearing in smoke or mist.

Passive Solar: A system in which solar energy alone is used for the transfer of thermal energy. Pumps, blowers, or other heat transfer devices that use energy other than solar are not used.

Peak Watt: A manufacturer's unit indicating the amount of power a photovoltaic cell or module will produce at standard test conditions (normally 1,000 watts per square meter and 25 degrees Celsius).

Photovoltaic Cell: An electronic device consisting of layers of semiconductor materials fabricated to form a junction (adjacent layers of materials with different electronic characteristics) and electrical contacts and being capable of converting incident light directly into electricity (direct current).

Photovoltaic Module: An integrated assembly of interconnected photovoltaic cells designed to deliver a selected level of working voltage and current at its output terminals, packaged for protection against environment degradation, and suited for incorporation in photovoltaic power systems. 
Pollution: Any substances in water, soil, or air that degrade the natural quality of the environment, offend the senses of sight, taste, and smell, and/or cause a health hazard. The usefulness of a natural resource is usually impaired by the presence of pollutants and contaminants.

Private Activity Bond (PAB): A bond in which more than 10 percent of the proceeds are secured by the interest in the property of a private business or used in a nonpublic business. A PAB can still be tax-exempt if used (at least 95 percent) for qualified investments, such as waste-to-energy facilities, and provided that State allocation caps are not exceeded.

Public Utility Regulatory Policies Act of 1978 (PURPA): One part of the National Energy Act, PURPA contains measures designed to encourage the conservation of energy, more efficient use of resources, and equitable rates. Principal among these were suggested retail rate reforms and new incentives for production of electricity by cogenerators and users of renewable resources.

Pulpwood: Roundwood, whole-tree chips, or wood residues.

Pyrolysis: The thermal decomposition of biomass at high temperature in the absence of oxygen.

Quadrillion Btu: Equivalent to 10 to the 15th power Btu.

Qualifying Facility (QF): A cogeneration or small power production facility that meets certain ownership, operating, and efficiency criteria established by the Federal Energy Regulatory Commission (FERC) pursuant to the Public Utility Regulatory Policies Act of 1978 (PURPA). (See the Code of Federal Regulations, Title 18, Part 292.)

Reformulated Gasoline (RFG): Gasoline whose composition has been changed (from that of gasolines sold in $1990)$ to (1) include oxygenates, (2) reduce the content of olefins, aromatics, and volatile components, and (3) reduce the content of heavy hydrocarbons to meet performance specifications for ozone-forming tendency and for release of toxic substances (benzene, formaldehyde, acetaldehyde, 1,3-butadiene, and polycyclic organic matter) into the air from both evaporation and tailpipe emissions.

Refuse-Derived Fuel (RDF): Fuel processed from municipal solid waste that can be in shredded, fluff, or densified pellet forms.

Renewable Energy Source: An energy source that is regenerative or virtually inexhaustible. Typical examples are wind, geothermal, and water power.
Retail Wheeling: An arrangement in which a utility transmits electricity from outside its service territory to a retail customer within its customer service territory.

Ribbon Silicon: Single-crystal silicon derived by means of fabricating processes that produce sheets or ribbons of single-crystal silicon. These processes include edgedefined film-fed growth, dendritic web growth, and ribbon-to-ribbon growth.

Roundwood: Logs, bolts, and other round timber generated from the harvesting of trees.

Scrubber: An emission control device that adds alkaline reagents to react with and neutralize acid gases.

Silicon: A semiconductor material made from silica, purified for photovoltaic applications.

Single Crystal Silicon (Czochralski): An extremely pure form of crystalline silicon produced by the Czochralski method of dipping a single crystal seed into a pool of molten silicon under high vacuum conditions and slowly withdrawing a solidifying single crystal boule rod of silicon. The boule is sawed into thin wafers and fabricated into single-crystal photovoltaic cells.

Smog: Air pollution associated with oxidants.

Solar Energy: The radiant energy of the sun, which can be converted into other forms of energy, such as heat or electricity.

Solar Thermal Collector: A device designed to receive solar radiation and convert it into thermal energy. Normally, a solar thermal collector includes a frame, glazing, and an absorber, together with the appropriate insulation. The heat collected by the solar thermal collector may be used immediately or stored for later use.

Solar Thermal Collector, Special: An evacuated tube collector or a concentrating (focusing) collector. Special collectors operate in the temperature (low concentration for pool heating) to several hundred degrees Fahrenheit (high concentration for air conditioning and specialized industrial processes).

Stoker Boiler: A boiler in which fuel is burned on a grate with the fuel supplied and the ash removed continuously. Most of the steam is used for process heat, with the remainder being used for electricity if desired.

Stranded Investment: Refers to the financial impairment-not necessarily plant closure in the physical sense-when the price of plant output falls to a level at which the owner can no longer earn a sufficient return on investment. 
Thermosiphon System: A solar collector system for water heating in which circulation of the collection fluid through the storage loop is provided solely by the temperature and density difference between the hot and cold fluids.

Tipping Fee; Price charged to deliver municipal solid waste to a landfill, waste-to-energy facility, or recycling facility.

Transmission System (Electric): An interconnected group of electric transmission lines and associated equipment for moving or transferring electric energy in bulk between points of supply and points at which it is transformed for delivery over the distribution system lines to consumers, or is delivered to other electric systems.

Turbine: A machine for generating rotary mechanical power from the energy of a stream of fluid (such as water, steam, or hot gas). Turbines convert the kinetic energy of fluids to mechanical energy through the principles of impulse and reaction, or a mixture of the two.
Vapor-Dominated Geothermal System: A conceptual model of a hydrothermal system where steam pervades the rock and is the pressure-controlling fluid phase.

Watt (Electric): The electrical unit of power. The rate of energy transfer equivalent to 1 ampere of electric current flowing under a pressure of 1 volt at unity power factor.

Watt (Thermal): A unit of power in the metric system, expressed in terms of energy per second, equal to the work done at a rate of 1 joule per second.

Watthour (Wh): The electrical energy unit of measure equal to 1 watt of power supplied to, or taken from, an electric circuit steadily for 1 hour.

Wheeling: The use of the transmission facilities of one system to transmit power and energy by agreement of, and for, another system with a corresponding wheeling charge, e.g., the transmission of electricity for compensation over a system that is received from one system and delivered to another system). 